FACULDADE DE FILOSOFIA, LETRAS E CIÊNCIAS HUMANAS

DEPARTAMENTO DE TEORIA LITERÁRIA E LITERTURA COMPARADA

PROGRAMA DE PÓS-GRADUAÇÃO EM TEORIA LITERÁRIA E LITERATURA COMPARADA

Elisabete Marin Ribas

Giz, caneta e pincel:

Literatura e História da Arte nas aulas do professor Osman Lins

São Paulo

2011 


\section{UNIVERSIDADE DE SÃO PAULO}

\section{FACULDADE DE FILOSOFIA, LETRAS E CIÊNCIAS HUMANAS}

DEPARTAMENTO DE TEORIA LITERÁRIA E LITERTURA COMPARADA

PROGRAMA DE PÓS-GRADUAÇÃO EM TEORIA LITERÁRIA E LITERATURA COMPARADA

\section{Versão corrigida}

Giz, caneta e pincel:

Literatura e História da Arte nas aulas do professor Osman Lins

Elisabete Marin Ribas

Dissertação apresentada ao Programa de Pós-Graduação em Teoria

Literária e Literatura Comparada do Departamento de Teoria Literária e Literatura Comparada da Faculdade de Filosofia, Letras

e Ciências Humanas da Universidade de São Paulo, para a obtenção do título de Mestre em Letras.

Orientadora: Prof ${ }^{\mathrm{a}}$. Dr ${ }^{\mathrm{a}}$. Sandra Margarida Nitrini

São Paulo 
À minha mãe, que me apresentou a arte da vida, pintada com as cores do amor. 
Agradecimentos

É difícil expressar em palavras meus agradecimentos diante da generosidade da vida, que me brindou com pessoas maravilhosas, sem as quais o presente trabalho não teria sido possível.

Agradeço inicialmente a Deus e a todas as bênçãos que diariamente Ele me dá.

À minha família que sempre confiou e me apoiou em minhas escolhas. Meu pai, minha mãe (a quem dedico este trabalho) e em especial minha irmã, presentes em todos os momentos.

Ao Fabio Rogerio Batista Lima, artista talentoso e amigo dedicado que não mediu forças para encontrar as imagens que compõem o corpus das aulas de História da Arte de Osman Lins. Por ele, conheci e agradeço de forma especial às bibliotecárias Maria Luzinete Euclides e Vania Maria Silveira Reis Fantin da Unesp de Marília, pelo empréstimo do material original utilizado por Osman Lins, durante o tempo em que foi professor na antiga Faculdade de Filosofia, Ciências e Letras da cidade.

À professora Sandra Nitrini, pela fidelidade, orientação e generosidade depositadas não só nesta dissertação, mas em todos os anos de trabalho conjunto no Fundo Osman Lins. Seu convite para me aprofundar na obra osmaniana, ainda em 2002, abriu portas preciosas e mudou minha vida, tornando-me a pessoa mais feliz do mundo.

Aos amigos André, Paulo e Pedro que de maneira tão especial ouviram minhas idéias e me contemplam com sua amizade leve e preciosa.

À Maria Carolina Turatti e Rosângela Felício dos Santos, companheiras osmanianas que me provaram que é possível encontrar a amizade verdadeira no ambiente acadêmico.

A todos os colegas e estudiosos da obra de Osman Lins, que com suas sensíveis e minuciosas análises, dialogaram direta e indiretamente comigo neste caminho. De modo especial, agradeço à professora Kazuco, precursora nos estudos sobre a atuação de Osman Lins como professor e Eder Rodrigues Pereira pelo incentivo e ajuda de sempre.

À Célia Sakai e Sueli, amigas inesquecíveis, apoios sólidos.

À Cida, que sem seu auxílio, este trabalho não teria sido possível.

Ao Instituto de Estudos Brasileiros, por ter se tornado mais um lar. À professora Maria Ângela Faggin Pereira Leite, pelo apoio. Ao laboratório de Informática, nas pessoas do Denis e da Rosana, sempre disponíveis e carinhosos a todos meus pedidos. À professora Mayra Laudanna, pela ajuda inicial na busca pelas imagens de referências. E à equipe do Arquivo, com meus colegas e estagiários queridos, pela ajuda, paciência e apoio diários, em especial durante os dois meses em que precisei me afastar para finalizar o presente trabalho.

A todos os docentes e funcionários do Departamento de Teoria Literária e Literatura Comparada, com agradecimento detid ao período emq eu me foi concedida a bolsa Capes. Meu muito 
obrigada especial às meninas Ângela, Sueli, Maria e Zilda pela alegria. Ao Luís e Maria, pela atenção incondicional a todos os meus inúmeros pedidos, até o último minuto.

Às filhas do escritor Osman Lins - Letícia, Litânia e Ângela - que cientes da grandiosidade da obra deixada por seu pai, apóiam de maneira exemplar não só minha pesquisa, como a de tantos outros pesquisadores que as buscam. Também, de modo carinhoso, agradeço a Ângela, pela amizade que surgiu no decorrer deste trabalho e que certamente permanecerá.

Agradeço, nesta versão final as contribuições das queridas professoras Marisa Balthasar Soares e Ana Paula Cavalcante Simioni, tanto na banca de qualificação quanto na presente redação da dissertação.

Aos notáveis amigos dos Seminários de Estudos Epistemológicos e Didática da Faculdade de Educação, que nos encontros semanais despertaram muitas das idéias aqui esboçadas.

A todos os meus professores, de todas as etapas da minha formação, que despertaram em mim o desejo e a paixão pelo conhecimento.

E ao Fred por ser o que ele é. 


\section{Giz, caneta e pincel: Literatura e História da Arte nas aulas do professor Osman Lins}

\section{RESUMO}

Osman Lins, escritor pernambucano, em 1970, ao ser convidado a assumir a cadeira de Literatura Brasileira na Faculdade de Filosofia, Ciências e Letras de Marília (atual UNESP), propõe a seus alunos experiências didáticas inovadoras para a época. Dentre elas constou um curso extracurricular, de História da Arte. Tal curso, gravado em fitas cassetes pelo escritor, hoje salvaguardadas no Arquivo do Instituto de Estudos Brasileiros, é composto de aulas audiovisuais que ilustravam o conteúdo programático, narrado por Osman Lins. Na presente pesquisa, esse material foi transcrito e parte das imagens recuperadas. Junto dos planos de aulas de Literatura Brasileira, o Curso de História da Arte, traz à luz um novo lado do escritor, que em sala de aula, permaneceu firme aos seus ideais literários.

\section{Palavras-chave:}

Osman Lins - Literatura Comparada - Literatura Brasileira - História da Arte - Ensino de Literatura 


\title{
Giz, caneta e pincel: Literatura e História da Arte nas aulas do professor Osman Lins
}

\begin{abstract}
When Osman Lins, a writer from Pernambuco, was invited to take the chair of Brazilian Literature in Faculdade de Filosofia, Ciências e Letras de Marília (today UNESP), he proposed to his students didactic approaches that were innovative at the time. Among them he included an extracurricular course of Art History that was recorded in tapes which nowadays are kept in the Archive of the Instituto de Estudos Brasileiros. That course is structured of audiovisual classes in which images illustrated the content presented by Osman Lins. In our research the original audio was transcribed and most of the base images was recovered. Along with the lessons plans of Brazilian Literature, the course of Art History bring to light a new face of the author, who in class maintained alive his literary ideals.
\end{abstract}

\section{Key-words:}

Osman Lins - Comparative Literature - Brazilian Literature - Art History - Literature Teaching 


\section{Índice}

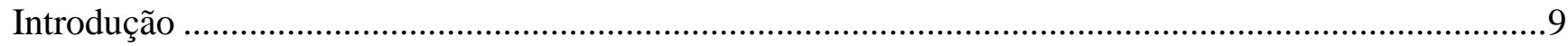

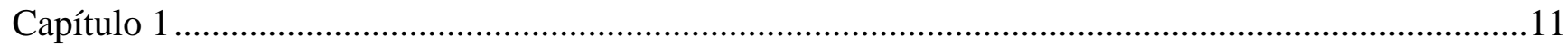

A formação do escritor e a trajetória do professor ............................................................................11

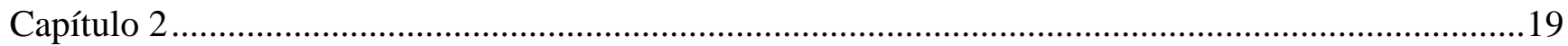

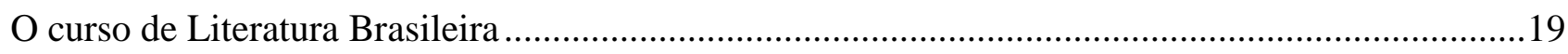

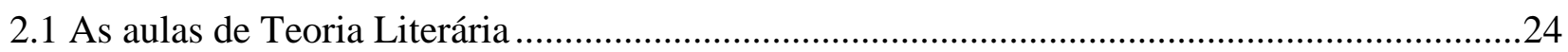

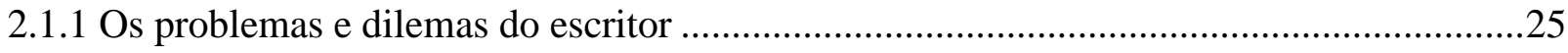

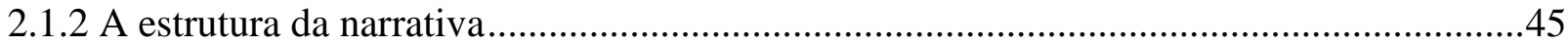

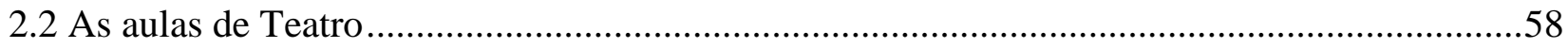

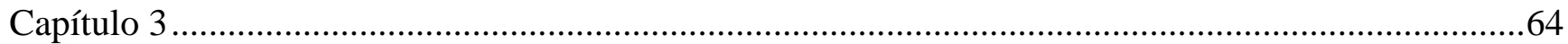

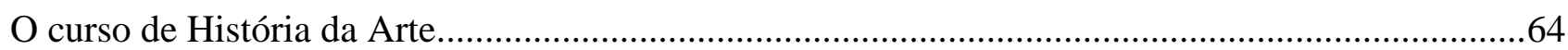

3.1 Literatura e outras artes na Teoria Literária e na obra osmaniana ........................................64

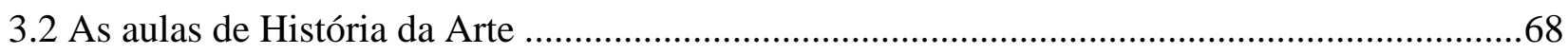

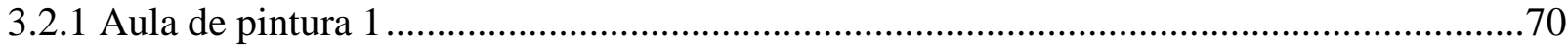

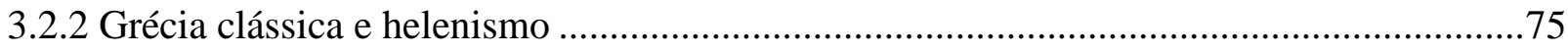

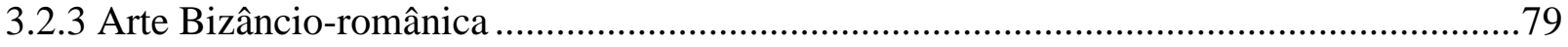

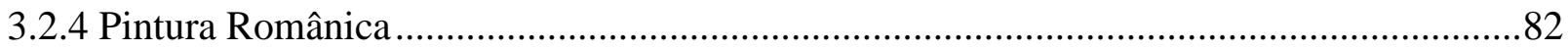

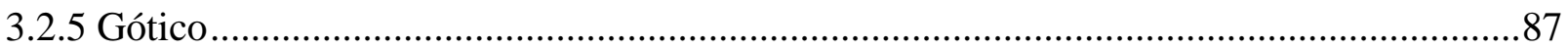

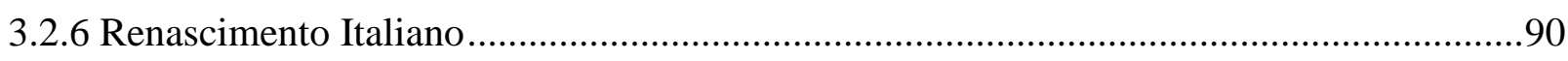

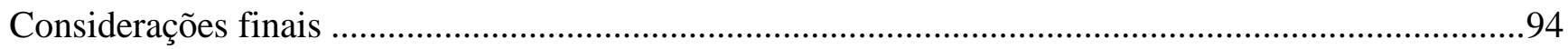

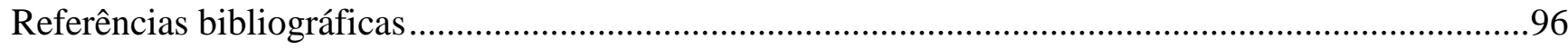

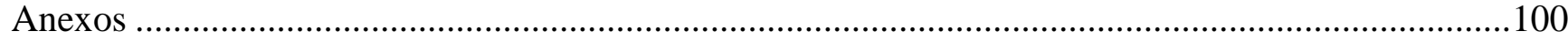

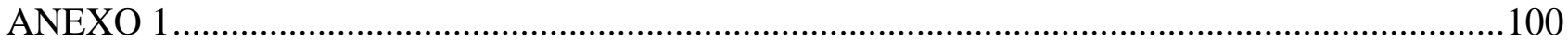

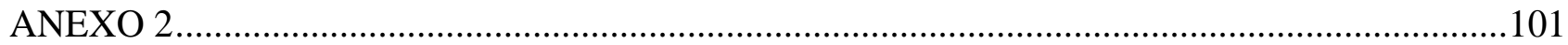

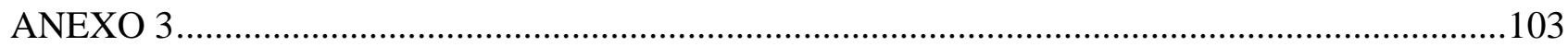

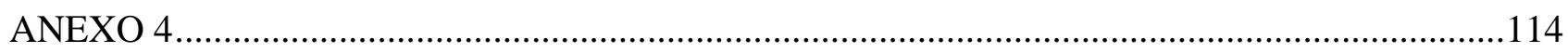

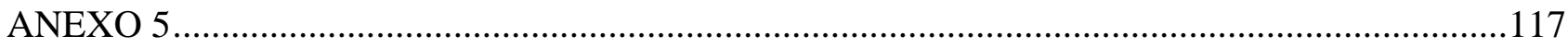

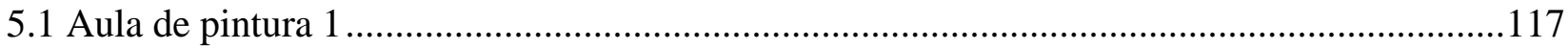

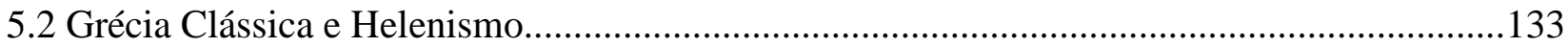

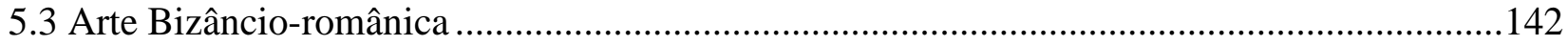

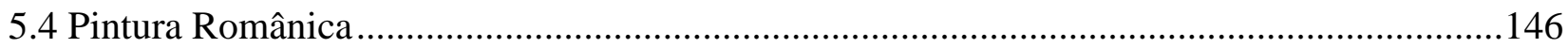

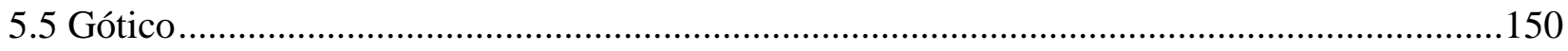

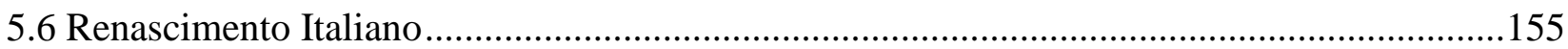




\section{Introdução}

Osman Lins, ao ser convidado a assumir, em 1970, a cadeira de Literatura Brasileira na Faculdade de Filosofia, Ciências e Letras de Marília ${ }^{1}$, optou por, assim como em sua obra literária, seguir suas próprias convicções, e propôs práticas que fugiram aos tradicionais currículos utilizados por instituições universitárias. Dentre suas aulas de Literatura, surgiram atividades pedagógicas que contaram com a encenação de peças teatrais, a escrita de programas de rádio e um curso extracurricular, de História da Arte, pois, segundo o escritor-professor, a formação em Letras necessitava de conceitos básicos de artes plásticas, visando um pleno desenvolvimento estético. O curso em questão era composto de aulas audiovisuais, acompanhadas de conteúdo programático, narrado por Osman Lins, de forma que as sessões eram ricas em estímulos sensoriais diversos. Esse material foi reconstituído através da transcrição do seu áudio e da recuperação das imagens utilizadas.

Tendo em mãos os planos de aulas do professor Osman Lins, buscaremos levantar seus principais temas e analisar seu conteúdo, com o objetivo de identificar possíveis relações entre sua atividade na docência, sua produção literária e intelectual e seu curso extracurricular de História da Arte. No primeiro capítulo, realizamos breve apresentação biográfica do escritor, contextualizando cronologicamente sua produção literária até o momento em que assume a função de professor. No segundo capítulo, descrevemos o curso de Literatura Brasileira, a partir do discurso do professorficcionista, que denuncia a marginalização da carreira do escritor e, crítico da própria obra narrativa, utiliza sua produção literária para desenvolver junto aos alunos, a análise dos elementos da narrativa. Finalmente no terceiro capítulo, deter-nos-emos no curso de História da Arte, que complementará o curso de Literatura Brasileira, ao mesmo tempo que ilustrará as preferências estéticas de Osman Lins. Nas citações colhidas dentre os documentos ${ }^{2}$ do escritor, foi-se mantida a grafia e acentuação do texto original, produzida por Osman Lins.

1 FFCL de Marília, atual UNESP.

2 Os documentos utilizados encontram-se atualmente salvaguardados no Arquivo do Instituto de Estudos Brasileiros da USP. Cabe dizer que também há um conjunto de documentos salvaguardados na Fundação Casa de Rui Barbosa, que no presente trabalho, não foram utilizados. 
Advertimos que os planos de aula e sua produção escrita aproximam-se. Sem grandes pretensões ou com o aprofundamento necessário, isso será apontado no decorrer de todo o trabalho. Apesar de formarem um corpus autônomo em relação à obra do escritor, ambos os cursos, tanto o de Literatura Brasileira, como o de História da Arte, travam um diálogo profícuo, e na qualidade de documentos fontes, tornam-se novas ferramentas no denso exercício de compreensão da hermética literatura osmaniana. 


\section{Capítulo 1}

\section{A formação do escritor e a trajetória do professor}

Sabemos da seriedade e paixão com que Osman Lins via o ofício de escritor. O germe dessa atração tem sua origem na infância ${ }^{3}$, a partir do contato com seu tio, Antonio Figueiredo, exímio contador de histórias.

Era meu tio, e quando eu era pequeno, ele, que viajava muito, me maravilhava até altas horas da noite a narrar as suas viagens. (...) Foi ele quem despertou em mim o gosto de narrar. (apud IGEL, 1988, p. 22-23)

Aos 11 anos, escreve o primeiro poema. Ao fim do curso ginasial, a percepção de que sua cidade natal, Vitória de Santo Antão, não lhe proporcionaria ambiente profícuo para seu desenvolvimento intelectual e cultural desejados, se avulta. Deste momento em diante, as escolhas da sua vida passam a ser primordialmente direcionadas para a concretização de uma carreira literária: mudanças (de Vitória de Santo Antão para Recife, até que posteriormente dirige-se a São Paulo) e viagens (Europa em várias ocasiões, América Latina); curso de dramaturgia na Escola de Belas Artes da Universidade do Recife, concomitante a atividades que lhe proporcionariam apoio financeiro enquanto se desenvolvesse e consolidasse como escritor (curso de contabilidade, emprego no Banco do Brasil, cátedra de Literatura Brasileira na Universidade de Marília).

Algumas das experiências acima citadas, mais do que simplesmente atuarem como coadjuvantes no processo de sua formação literária, acabaram também por ter papel ativo na conformação da obra osmaniana. O curso de dramaturgia, evidentemente, serviu de ponto de partida para toda a produção teatral de Osman Lins, resultando em peças como Lisbela e o prisioneiro e Guerra do cansa-cavalo ${ }^{4}$. A primeira viagem à Europa acaba por tornar-se base para a elaboração de

3 Tal fato nos remete ao relato de José de Alencar, registrado em sua biografia literária Como e porque sou romancista. Rio de Janeiro: Leuzinger \& Filhos, 1893.

4 Para os estudos de sua produção teatral, apontamos os trabalhos de Maria Teresa Dias Um teatro que conta: a dramaturgia de Osman Lins, tese de doutorado apresentada junto ao Programa de Pós Graduação em Teoria Literária da FFLCH-USP, São Paulo: 2004 e Marisa 
Marinheiro de primeira viagem, obra que mistura ficção e relato de viagem, tendo como pano de fundo as experiências culturais no velho continente. Da mesma maneira, o trabalho de professor e pesquisador numa universidade possibilitou que o escritor exercitasse suas idéias sobre arte e Literatura para um outro tipo de audiência.

O ingresso na Faculdade de Filosofia, Ciências e Letras de Marília, deu-se em 1970. O início dessa década ainda está marcado pela violência da imposição do Ato Institucional $\mathrm{n}^{\circ} 5$, o conhecido AI5, publicado a 13 de dezembro de 1968. A despeito disso, verifica-se uma ampliação e o incentivo de atividades relacionadas à produção cultural, chamada pela crítica de "modernização autoritária"s.

\begin{abstract}
A partir desse momento, pode-se notar uma série de modificações sensíveis nas várias frentes de produção cultural. As revisões radicais, observáveis de 1964 a 1969, foram envolvidas num círculo de ferro, e nesse sentido a censura e a autocensura exerceram papel decisivo. (MOTA: 2008, p.299)
\end{abstract}

Ironicamente, encontra-se nesse período, significativo aumento e incentivo de produção de jornais, revistas, e em especial, da TV brasileira. Ao mesmo tempo, a produção de tais meios sofre com o controle de conteúdo, de forma violenta, repressora e autoritária, impostas pelo regime militar.

A educação também ganha significativa expansão, seja na escola de base, seja no nível universitário. ${ }^{6}$ Nesse setor assistimos a uma ampliação de vagas e cursos, especialmente nos campi do interior. É em decorrência desse contexto que Osman Lins obtém sua posição junto ao curso de Letras da Universidade de Marília.

Como professor universitário, Osman Lins assumiu duas responsabilidades: ministrar Literatura Brasileira para os alunos da faculdade e elaborar um projeto de pesquisa. Mais do que duas atividades burocráticas e independentes, ambas tornaram-se produtos da reflexão literária imanente a qualquer produção osmaniana, além de representarem a dedicação, característica marcante do escritor, também presente em todo o fazer de Osman Lins.

\footnotetext{
Balthasar Soares, Aspectos do teatro de Osman Lins em Retábulo de Santa Joana Carolina, dissertação de mestrado apresentada junto ao Programa de Pós Graduação em Teoria Literária da FFLCH-USP, São Paulo: 2003.

5 Termo usado por Renato Ortiz, no ensaio Sociedade e cultura. In: PINHEIRO, Paulo Sérgio (org.). Brasil: um século de transformações. São Paulo: Companhia das Letras, 2001, p.200.

6 Acerca disso, indicamos o trabalho de Willington Germano, Estado militar e educação no Brasil : 1964/1985 : um estudo sobre a politica educacional, tese de doutorado apresentada junto ao Programa de Pós Graduação em Educação, da Faculdade de Educação da UNICAMP, Campinas: 1990.
} 
No que tange a sua atividade de ensino, a postura do Osman Lins professor reflete o temperamento do Osman Lins escritor. Ambos valorizam experimentalismo, engajamento, disciplina, sendo todos esses pontos permeados de profundo idealismo. Em 1970 já estamos na chamada "fase madura"7 da produção literária de Osman Lins, inaugurada por Nove, novena (1966), primeira obra do autor que apresenta inovadora estrutura narrativa. Essa inovação demonstra a insatisfação do autor com a sua obra anterior, uma tentativa de resolver problemas literários que o perseguiam, a busca de "uma expressão pessoal”, de métodos de concepção e de execução que devessem pouco a obras alheias $^{8}$. No exercício do magistério, por sua vez, Osman Lins também tentou remediar a falta de preparação literária de seus alunos e criar alternativas para um currículo que não era adequado para sanar essas dificuldades. “A condução pedagógica de Osman revela-se contrária à prática corrente nas faculdades. Na tentativa de passar aos alunos a paixão pela Literatura, cria experiências totalmente inovadoras" (HIGUCHI, 2009, p. 45). Um desses expedientes será a ampliação do cânone literário que, segundo ele, no Brasil, era restrito e unilateral, contemplando alguns poucos nomes, sem abrir espaço para grandes literatos da cultura brasileira. Na sala de aula, as crônicas de Gabriel Soares de Souza tornaram-se um programa de TV:

O Tratado Descritivo do Brasil de Gabriel Soares de Souza transformou-se em um imaginário programa de TV. A equipe, ao apresentar uma antologia desse cronista, chamou a atenção pelas dicções variadas e pela inserção de comerciais elaborados a partir das informações contidas no livro como madeiras de lei, pedras preciosas, bebidas, peixes. Nesse caso também é possível imaginar o envolvimento dos alunos na leitura de obra tão distante deles, escrita nos primeiros tempos do descobrimento do Brasil, repetindo, de certa forma, o estranhamento sentido pelo cronista frente aos produtos de uma nova terra. (HIGUCHI, 2009, p. 47)

Outro exemplo de sua inquietação demonstra-se na obra Lima Barreto e o espaço romanesco ${ }^{9}$ (1976). Fruto de sua tese de doutorado, título exigido quando assume a cadeira de Literatura Brasileira, o trabalho apontará a importância da obra de Lima Barreto, escritor ainda hoje marginalizado em livros e apostilas escolares. Usando as próprias palavras do autor:

\footnotetext{
7 Sobre isso, em entrevista, Osman Lins declara: "Mas o Nove, novena inaugura uma fase de maturidade, talvez de plenitude, em minha vida de escritor". (LINS: 1979, p. 141). Ver também ANEXO 1.

8 Ibid, p. 141.

9 A dissertação de doutorado foi defendida em 1973, na Universidade de São Paulo e publicada, posteriormente em 1976, recebendo o número 20 da Coleção Ensaios, pela Editora Ática.
} 
Esse desconhecimento relativo é injusto e só não espanta porque já temos ciência da debilidade que caracteriza o nosso panorama intelectual, propenso, como na vida agrária, à monocultura, à queimada e ao abandono de terrenos férteis. (LINS, 1977, p. 172)

Também a dinâmica das aulas sofreu mudanças. Em relatório apresentado à Comissão Permanente de Tempo Integral de [1971/1972], Osman Lins apresenta seu curso de Literatura Brasileira:

Para trabalhar, todavia, na linha de criação e interpretação, as classes serão divididas em um determinado grupo, sobre a direção de um orientador. Inicialmente, trabalharei apenas com esses orientadores, os quais, sob a minha direção, realizarão perante as classes, em várias sessões, uma NARRATIVA. Mas a elaboração dessa narrativa não se processará ao acaso, como será intercalada com aulas expositivas sob aspectos estruturais da narrativa. (Tal gênero, este ano, será predominante.) (...)

Também está prevista para uma das turmas, a realização de um texto dramático. ${ }^{10}$

Em relação à questão do engajamento, abunda na produção ensaística de Osman Lins uma visão crítica e incorformista dos problemas sociais e culturais brasileiros ${ }^{11}$. Alguns dos temas abordados são, quanto ao escritor, o difícil reconhecimento do ofício, sua marginalizada condição social, o problema de obtenção dos direitos autorais, a criação dos cartéis de editoras e casa de publicação, os parcos recursos para o desenvolvimento cultural e a escassa produção artística de qualidade; quanto à sociedade brasileira, aborda a precariedade das condições de vida no nordeste, a dificuldade da obtenção dos benefícios sociais, o duvidoso sistema de ensino entre outros pontos. Na sala de aula, não se retrairá diante das deficiências impostas pela estrutura do sistema educacional. Nesse sentido, por exemplo, durante seu período como professor, Osman Lins propôs o que chamou de Curso de Composição Oral e Escrita:

(...)o Curso de Composição Oral e Escrita planejado para o ano letivo de 1972 e destinado 'a compensar as deficiências de redação verificáveis em muitos dos alunos que iniciam o Curso de Letras' não sendo 'um curso rigorosamente de nível universitário. Antes, visa a criar, nos alunos do primeiro ano, condições para um melhor desempenho em seus trabalhos nos anos subseqüentes' (...) (HIGUCHI, 2008, p. 49) 
Outro exemplo que vai além da sala de aula e demonstra seu engajamento social, será o Curso de Atualização de Professores Secundários. Segundo Kazuko Higuchi

\begin{abstract}
a preocupação de Osman Lins não se resumia aos alunos, aproveitava as possibilidades para ampliar seu raio de ação para onde julgasse necessária maior orientação sobre literatura. Propõe à direção da faculdade um Curso de Atualização de Professores Secundários.(HIGUCHI, 2008, p.49)
\end{abstract}

Resta-nos falar do rigor que atravessa as atividades de escrita e ensino. Para Osman Lins, a disciplina era quase uma questão de sobrevivência, uma forma de alcançar pelo método o que as circunstâncias de sua vida lhe negaram, ao mesmo tempo em que lhe fortalecia o caráter. Na vida, isso se manifesta no modo como planejava seu cotidiano. Evidência disso é a anotação presente no ensaio

\title{
Reflexões do jovem escritor:
}

$$
\begin{aligned}
& 5.30-6.00 \\
& 6.00-9.00 \\
& 9.00-9.30 \\
& 9.30-15-30 \\
& 15.30-15-45 \\
& 15.45-18.45 \\
& 18.45-20.00 \\
& 20-22.00 \\
& 22-22.30 \\
& 22.30
\end{aligned}
$$

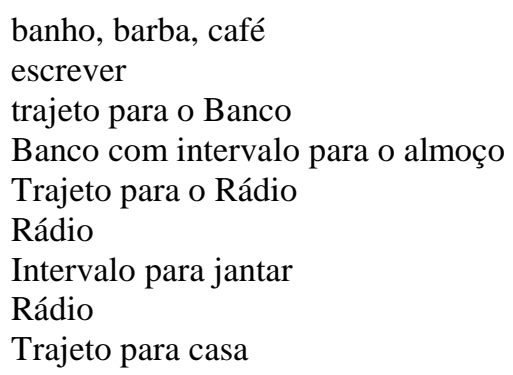

$\mathrm{Na}$ Literatura, testemunhamos o rigor matemático de construção de suas narrativas maduras, em especial Avalovara (1973). Na atividade docente, tomamos conhecimento da dedicação e do cuidado na preparação de suas aulas. Tal cuidado explicita-se nas tentativas de inovação didática, como já dito anteriormente, no seu envolvimento com os conteúdos ministrados, nas suas ações sociais de atendimento às necessidades dos alunos e dos professores do ensino secundário e, mais especificamente, como veremos adiante, na meticulosa elaboração das aulas do curso extra de História da Arte, oferecido aos alunos do curso de Letras, que contavam com recursos audiovisuais.

A pesquisa, outra face do trabalho de Osman Lins na universidade, contou também com inovação e ousadia. Novamente dirigindo-se à Comissão Permanente do Regime de Tempo Integral, 
A remuneração percebida como regente de cátedra, em regime de tempo parcial, é inferior aos seus vencimentos atuais no Banco e aos seus compromissos financeiros. Não lhe permite, por isto, desligar-se, como seria desejável, das suas funções burocráticas.

Aspira, portanto, ao regime de dedicação plena ao trabalho e à pesquisa, para o que deve, segundo estabelecem as normas vigentes, preencher determinados requisitos. Dentre estes, a apresentação de um "Plano de Pesquisa" na sua área de ensino.

CARACTERÍSTICAS DO PLANO - Vem, portanto, apresentar à douta Comissão Permanente do Regime de Tempo Integral (C.P.R.T.I), seu plano de trabalho: a realização de uma obra cujo título provisório será

A Arte de Tecer Romances,

de fatura extremamente árdua e pela qual perpassa, em termos que não podemos dizer ficcionais, uma meditação constante sobre a natureza da palavra. Terá, uma vez concluída, a extensão aproximada de trezentas páginas. Pretende ser, como texto, uma pesquisa nas potencialidades do nosso idioma, estendendo-se suas indagações ao próprio fenômeno da criação romanesca: a arte de escrever romances, precisamente, é o seu tema central. Para esta empresa, em gestação há cerca de um lustro, fluem as suas energias, faltando-lhe apenas as condições materiais para iniciá-la, no momento bastante adversas, visto ver-se obrigado, pelosmotivos(sic.) já expostos, a manter os vínculos com a organização bancária a que antes se referiu. $^{12}$

Em outras palavras, Osman Lins propõe como projeto de pesquisa a composição do romance Avalovara $^{13}$. Como se comprova que o referido trabalho trata-se da elaboração do romance Avalovara? Em plano de aula, dirigindo-se a seus alunos, Osman Lins fala sobre sua experiência como escritor, a partir de Nove, novena e o que almeja realizar com o romance que escreve no momento:

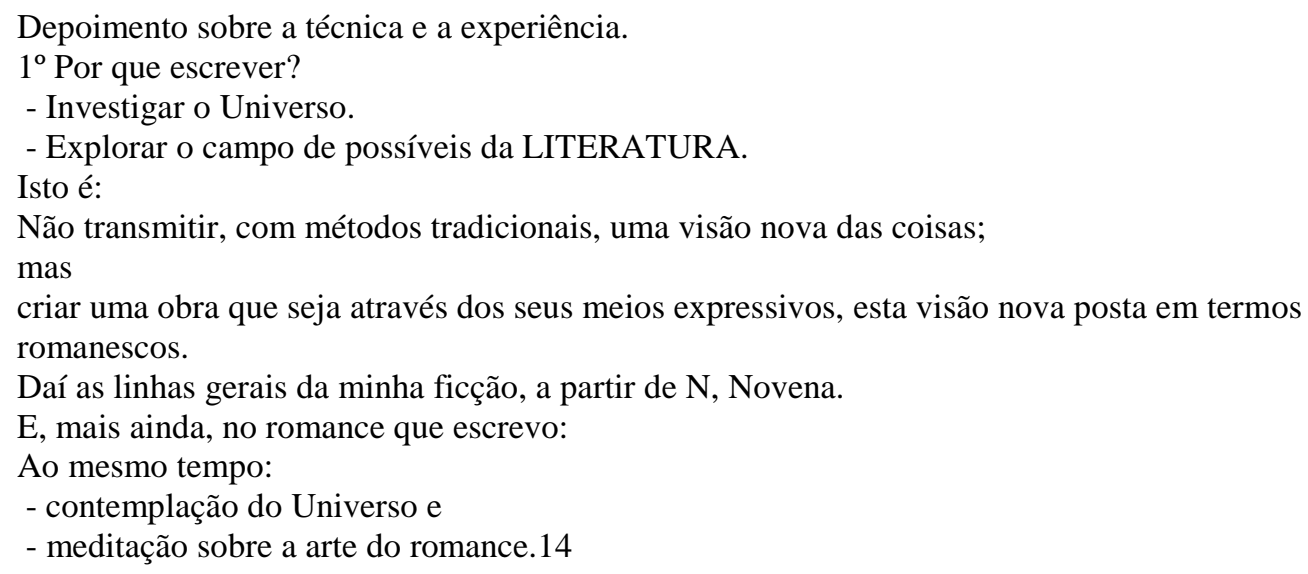

12 Arquivo do Instituto de Estudos Brasileiros USP - Fundo Osman Lins. Código do documento: OL/MAG/CX01/P02/02. É importante ressaltar que o documento apresenta Osman Lins dirigindo-se a si mesmo, na terceira pessoa.

13 Alertamos que o presente estudo debruça-se sobre a produção de Osman Lins como professor, na qual, pela força do conteúdo presente nos documentos analisados, a abordagem em relação ao processo de criação de Avalovara tornou-se necessário, porém não será aprofundada. Para tal, apontamos os estudos de Eder Rodrigues Pereira, chamado A chave de Jano - os trajetos da criação de Avalovara de Osman Lins: uma leitura das notas de planejamento à luz da Crítica Genética. Dissertação de Mestrado apresentada ao Departamento de Teoria Literária e Literatura Comparada da Faculdade de Filosofia, Letras e Ciências Humanas da Universidade de São Paulo. 2009. 14 Arquivo do Instituto de Estudos Brasileiros USP - Fundo Osman Lins. Código do documento: OL/MAG/CX02/P01/07 
Posteriormente à publicação de Nove, novena, seguirá Avalovara. As características "contemplação do Universo" e "meditação sobre a arte do romance" podem ser facilmente identificadas no romance, assim como a segunda delas pode ser associada ao título provisório, constante no relatório de 21/5/1970: “A Arte de Tecer Romances”. Não resta dúvida.

Por que isso nos interessa? Interessa na medida em que obra, pesquisa e aulas passam a fazer parte de um mesmo movimento produtivo. Mas, como obra e pesquisa são o mesmo, sobram somente obra e aulas que passam a se relacionar. Para demonstrar tal relação, faz-se necessário descrever mais detalhadamente o conteúdo e o formato das aulas do curso de Literatura Brasileira, o que será executado no Capítulo 2.

Finalizando o percurso do professor-escritor, infelizmente, apesar de um entusiasmo inicial, a experiência acadêmica passa a trazer mais desgostos que recompensas, seja em virtude da estrutura educacional universitária, da incompreensão da burocracia administrativa e de colegas ou do próprio desinteresse e deficiência dos alunos. O mesmo processo de expansão universitária, que deu a Osman Lins a oportunidade de lecionar na Faculdade de Filosofia, Ciência e Letras de Marília, é responsável por inúmeras decepções colhidas durante sua atuação docente, que se resumem na seguinte hipótese: nem todos os professores e alunos estavam aptos - devido a deficiências do próprio sistema -, a ocupar as vagas que lhe foram abertas, o que culmina na inviabilidade de iniciativas como as de Osman Lins.

Do próprio escritor, encontramos um desabafo diante da falta de envolvimento dos alunos:

\begin{abstract}
Dentro dêsse (sic) princípio, organizei uma excursão cultural dos alunos a São Paulo. Entrei em contato com várias pessoas e entidades: Secretaria de Turismo do estado (sic.) de S. Paulo, Conselho Estadual de Cultura, Secretaria de Turismo da Prefeitura de São Paulo, Departamento de Educação Física, Estádio Municipal do Pacaembu, Livraria Parthenon, Editôra Melhoramentos e Planetário Municipal. Providenciei transporte na Capital e reservei alojamento para 35 (trinta e cinco) alunos. Infelizmente, o entusiasmo inicial das classes cedeu lugar, nos dias que antecederam a excursão, a uma apatia súbita e geral, com o que se perdeu uma oportunidade que dificilmente se repetirá. ${ }^{15}$
\end{abstract}

No que diz respeito a outros empecilhos, podemos citar os seguintes testemunhos:

Como professor, Osman Lins constatou não ser possível transmitir o amor pela literatura como desejava. Após aposentadoria do Banco do Brasil, sua entrada tardia no magistério, 
sem prática docente, levou-o a traçar novas maneiras de conduzir o ensino de literatura provocando incompreensão na faculdade onde lecionava. ${ }^{16}$

A sua defesa de convicções, que jamais o abandonou, sempre produziu resultados extremados: um incidente com professores e dirigentes de uma faculdade paulista fez com que desse por encerrada a sua carreira de professor universitário, pouco tempo após uma defesa de tese de doutorado sobre Lima Barreto. O incidente originou-se do choque inevitável entre suas idéias, prática e concepções sobre o ensino universitário, com o desempenho insatisfatório daqueles que comandam e fazem, ainda hoje, o sistema educacional do país. Para aqueles professores, eram inaceitáveis a sua visão algo privilegiada e lúcida de escritor, somada a seu posicionamento crítico e atuante, e dissociados ambos dos cânones vigentes. (MONTEIRO apud. HIGUCHI, 2008, p.23)

Em 1976 Osman Lins desliga-se da cátedra de Literatura Brasileira e finaliza sua carreira como professor. A partir daí, irá dedicar-se à sua obra, gerenciando seus direitos autorais, republicando títulos no Brasil e no exterior, colaborando culturalmente como correspondente em jornais e revistas e claro, compondo textos que hoje fazem parte do compêndio de sua produção escrita. 


\section{Capítulo 2}

\section{O curso de Literatura Brasileira}

“Assim, o estudante e professor de Letras, também num país que tem de enfrentar problemas de subdesenvolvimento, tem o seu papel definido. Deixar claro a necessidade de enriquecer e iluminar a vida dos homens" Osman Lins ${ }^{17}$

Uma reconstituição do curso de Literatura Brasileira ministrado por Osman Lins pode valer-se de diferentes fontes: documentos de arquivos públicos ou privados, textos e entrevistas do autor, ou mesmo, alguns estudos que tematizaram sua carreira docente. No Instituto de Estudos Brasileiro da Universidade de São Paulo encontra-se abrigada parte da documentação pessoal do escritor pernambucano. Tal conjunto foi ali depositado graças à doação realizada por Julieta de Godoy Ladeira, segunda esposa de Osman Lins, sendo composto de documentos produzidos e acumulados durante sua vida, e significativamente complementados por material póstumo. Fazem parte desse fundo de arquivo os planos de aula de Literatura Brasileira e, como se verá adiante, aulas integrais de História da Arte, gravadas em fitas cassetes. Esse material contém a estrutura e a base teórico-expositiva do curso. A partir das demais fontes, como entrevistas e ensaios de Osman Lins sobre o ensino universitário, muitos deles publicados, temos acesso à dinâmica de funcionamento das aulas. Quanto aos estudos de terceiros, podemos citar Igel (1988) e Higuchi (2008), tendo o último desenvolvido trabalho pioneiro na investigação do trabalho em sala de aula de Osman Lins ${ }^{18}$. Nesta dissertação, privilegiaremos a análise do material documental, composto dos planos de aulas, e das aulas integrais em suporte sonoro. O curso de Literatura Brasileira ministrado por Osman Lins ocorre no período em que exerceu a docência na FFCL de Marília. Chamaremos aqui de aulas de Literatura de Osman Lins um conjunto heterogêneo de notas e planos de aulas, palestras e depoimentos preparados pelo escritor durante sua

17 Arquivo do Instituto de Estudos Brasileiros USP - Fundo Osman Lins. Código do documento: OL/MAG/Cx2/P2/13

18 Cabe indicar ainda o artigo de Wladimir Garcia, Osman Lins Educador, que traça um paralelo entre a atuação pedagógica de Osman Lins e aspectos filosóficos, com especial atenção aos conceitos nietzschianos, que por suas características muito específicas, não será utilizado neste trabalho. 
ação como professor. Não é possível estabelecer com precisão uma cronologia de produção e utilização desse material em sala de aula, mas é possível agrupá-los em temas e sub-temas, que provavelmente foram abordados em conjunto.

O primeiro registro das propostas que norteavam o curso de Literatura Brasileira encontra-se em relatório docente apresentado por Osman Lins:

\begin{abstract}
Notei que se alunos reagem de maneira mais fecunda, em relação à matéria, quando abordados aspectos teóricos. O enfoque histórico atinge-os menos. Por outro lado, pude constatar uma acentuada dificuldade, por parte da maioria dos alunos, em compreender certos aspectos do fenômeno literário. Parece-me que tais dificuldades decorrem de uma falta de vivência do fenômeno, visto e estudado sempre de fora, isto é, nunca praticado. Sendo além de Professor, um criador de Literatura, creio poder trabalhar com os alunos na área mesma da criação, ainda que seja um grau mais ou menos limitado. É esta, pois, a orientação básica que pretendo agora imprimir ao Curso, com o que, aliás, estarei correspondendo a um dos motivos nos quais se buscou minha contratação: a circunstância de ser um escritor. ${ }^{19}$
\end{abstract}

E mais adiante, no mesmo relatório:

Seguirei com os alunos, é certo, duas linhas paralelas. Uma, mais limitada, de simples memorização; outra, mais complexa e ambiciosa, de criação e interpretação. Na primeira, os alunos irão tomando conhecimento da evolução histórica das letras nacionais. Será esta, uma parte por assim dizer, mecânica e subsidiária, porém indispensável. Tal estudo, de caráter tradicional, será feito por todos indiscriminadamente. ${ }^{20}$

Em concordância com esses propósitos, Osman Lins divide o curso em três partes:

1) Teoria Literária e Processo de Composição;

2) Arte Dramática/ Teatro e

3) Curso extracurricular de História da Arte.

Analisemos cada uma das partes mais detalhadamente. A seção chamada Teoria Literária e Processo de Composição é composta por cerca de 30 roteiros de aulas, alguns em duplicata. Muitos deles apresentam-se na forma de esquemas, servindo como um guia temático para a aula expositiva. Outros são textos integrais, inclusive com título e indicação de autoria. Dentre os títulos, encontramos: 
"Códices e incunábulos"; "Para atingir seus fins, o escritor dirige-se ao homem através do livro"; "Perfil do escritor"; "Problemas e dilemas do escritor brasileiro"; "O escritor, o livro e o editor"; "Em que medida é consciente o trabalho do ficcionista"; "Relações de um ficcionista com seus personagens"; "A realidade cultural brasileira e a direção dos estudos literários"; "O problema do ensino de Literatura/ Prof. Osman Lins"; "O texto literário"; "A narrativa"; "Foco narrativo"; "Métodos de composição/ Depoimento de Osman Lins (resumo)". Nota-se a predominância dos temas já anunciados por Osman Lins em seus relatórios docentes. A espinha dorsal do curso passa pela discussão do ofício do escritor - lembremos que um ano antes de assumir a cátedra em Marília, Osman Lins publica Guerra sem testemunhas: o Escritor, sua Condição e a Realidade Social (1969) -, uma análise da narrativa e seus elementos estruturais ${ }^{21}$, e reflexões sobre o processo de criação literária a partir da experiência do próprio professor-escritor ${ }^{22}$. Nesse último tópico, a estrutura e o método de composição de Nove, novena e Avalovara serão explícitas e extensamente explicadas.

Quanto aos planos de aulas dedicados ao Teatro, encontramos um conjunto de cerca de 40 títulos, dentre eles: "As origens da arte. Teoria do jôgo"; "Concepção Kantiniana da arte/ O trágico/ O cômico/ A arte e a moral"; "O sublime - Kant/ Gratuidade da arte/ O mal e o feio na obra de arte/ o drama"; "As fontes teatrais"; "O texto teatral"; "Realismo do texto teatral"; "Relação entre o texto e o espetáculo"; "As regras teatrais"; "O clímax"; "A peripécia"; "A linguagem dramática e a cômica"; "Planificação da comédia"; "Planificação do drama"; "A tragédia"; "O dramático"; "O cômico"; "A tragédia grega"; "A tragédia Elizabetana"; "O primeiro ato"; "Planificação da ação tragédia"; "A linguagem trágica"; "Teoria de Arte Dramática - Ponto 18/ O personagem trágico". Pelos títulos podemos ver que a estrutura do curso é mais tradicional e menos pessoal, provavelmente devido à influência do Curso de Dramaturgia na Escola de Belas Artes da Universidade do Recife ${ }^{23}$, freqüentado por Osman Lins.

23 Ressalta-se aqui, o que será demonstrado adiante, quando, em análise aprofundada da documentação, constatou-se que o material, em verdade, apresenta na íntegra as aulas de Osman Lins, como aluno, no referido curso. 
Finalmente, o Curso de História da Arte vem complementar o curso de Literatura Brasileira. No mesmo relatório docente já citado, o autor apresenta uma justificativa para a aplicação desse assunto extracurricular:

Não havendo uma cadeira de História da Arte, serão dadas durante o ano quatro aulas sobre arte com projeção de diapositivos. Tal curso que se beneficia da experiência do ano anterior será concluído em 1973. ${ }^{24}$

Inserido dentro do programa de Literatura Brasileira, o Curso de História da Arte também conta com a experiência dos anos anteriores. Quanto às técnicas expositivas Osman Lins diz:

\begin{abstract}
Paralelamente ao curso de Literatura Brasileira propriamente dito, apresentamos, eu e a Professôra Suzi Frankl Sperber, um curso sintético de artes plásticas, utilizando diapositivos adquiridos por iniciativa da Cadeira; e que abrangeu, em oito aulas, o Egito, o período helenístico, o romântico, o bizantino e o barroco, chegando até à Arte Moderna. Visamos, com isto, suprir a pouca ou nenhuma familiaridade dos alunos com museus, visto julgarmos necessária, no estudante de Letras, uma abertura em relação a outros meios de expressão artística. 25
\end{abstract}

A preservação das aulas desse curso seguiu uma lógica diversa das demais. Ao invés de planos de aula datilografados e/ ou manuscritos, as aulas de História da Arte foram gravadas, aparentemente, na íntegra, em fitas cassetes. O texto é narrado pelo próprio Osman Lins. Ao fundo, ouve-se uma trilha sonora especialmente selecionada e relacionada ao conteúdo temático da aula. Ao longo da narração, o professor faz referências e, em determinados casos, desenvolve análises de imagens de obras de artes, monumentos ou artefatos arqueológicos. Ao final de algumas apresentações, Osman Lins enumera os livros utilizados. Parte deles foi encontrada, o que resultou na recuperação dos diapositivos que reproduzem suas ilustrações. Como podemos ver, esse curso aposta em recursos audiovisuais diversos, na tentativa de sensibilizar a percepção estética do aluno de Letras.

Uma das atividades da presente pesquisa comportou a tentativa de reconstituição do Curso de História da Arte. Infelizmente, do conjunto de aulas, aquelas referentes ao Barroco e à Arte Moderna não puderam ser recuperadas. Relatos da professora Sandra Nitrini, que participou da equipe que teve o primeiro contato com os documentos, quando estes chegaram ao IEB, fazem menção a um bilhete 
deixado pela também escritora e então viúva de Osman Lins, Julieta de Godoy Ladeira, que revelava o empréstimo de uma das fitas a uma editora. Acredita-se que a viúva de Osman Lins tivesse interesse em publicar o material, o que justificaria a cessão. Nas três fitas que restaram, está registrado um conjunto de seis aulas, em gravações que duram em média trinta minutos. Os títulos são:
1) Aula de pintura 1;
2) Grécia clássica e helenismo;
3) Arte Bizâncio-românica;
4) Pintura Românica;
5) Gótico e
6) Renascimento Italiano.

Posto isto, dois pontos saltam aos olhos. A idéia de introduzir um curso de História da Arte dentro de um curso de Literatura reflete uma tendência de Osman Lins, já notada nas suas primeiras produções literárias, mas intensificada após sua viagem à Europa, em 1961: misturar técnicas literárias com técnicas das artes visuais. Assim, não só o entendimento da Literatura deve passar pelo entendimento das outras artes, como também o fazer literário é enriquecido com a utilização de elementos técnicos emprestados das artes plásticas. Além disso, assim como as aulas teóricas sobre narrativas, o presente curso também traz marcas pessoais de Osman Lins, que dá ênfase para a seleção de temas e imagens que atendam suas preferências estéticas.

Essa descrição preliminar das aulas, sumária e esquemática, permite que vejamos como as duas atividades docentes de Osman Lins na universidade, o ensino e a pesquisa, estão intimamente relacionadas, na medida em que, já o demonstramos, o projeto de pesquisa coincide com a elaboração de sua própria obra (Avalovara) e, em que as próprias aulas são invadidas pela apresentação e dissecação do seu próprio fazer literário, seja de obras já publicadas, como Nove, novena, seja de trabalhos em elaboração, como Avalovara. Assim, mesmo enquanto professor, é sempre o escritor que fala. 


\title{
2.1 As aulas de Teoria Literária
}

"O prof. de Literatura, em geral, é um mestre em balística, atua no polígino de tiro. Mas o escritor está em combate."

Osman Lins 26

As aulas de teoria literária de Osman Lins são um dos testemunhos mais poderosos deixados por um autor de Literatura sobre os problemas, dilemas e determinações vividos por um escritor brasileiro nas décadas de 1960 e 1970. Com temática abrangente, recursos diversificados e técnicas didáticas um tanto peculiares para a época, o professor justifica suas escolhas em depoimento posterior à sua atuação:

\begin{abstract}
(...) o objetivo da experiência, como já disse, era familiarizar o estudante com os nomes que iniciam a nossa Literatura. Procurava-se, ao mesmo tempo, armar os alunos para iniciativas semelhantes em suas aulas no curso médio. Essas experiências, além do mais, não constituíam todo o programa e sim uma parte dele. Promovemos, por exemplo, ao mesmo tempo que se procura evocar nosso passado literário, debates sobre autores e obras contemporâneos: Dalton Trevisan, Clarice Lispector, Ricardo Ramos etc.

Pode-se também achar os recursos mencionados pouco solenes, pouco austeros, talvez festivos demais. Mas se o próprio Anchieta não hesitava em divertir-se para ensinar coisas celestes, por que seria eu mais ortodoxo no ensino de coisas humanas?

Acrescento que, em provas realizadas com as turmas empenhadas nesses projetos, o aproveitamento foi, em geral muito melhor que nos anos anteriores, quando usados métodos mais rotineiros e sérios. (LINS:1977, p. 74)
\end{abstract}

Infere-se destas palavras que o compromisso de Osman Lins com os estudantes extrapola o mero cumprimento de um conteúdo programático curricular: ele era marcado também pelo desejo de oferecer uma vivência em sala da aula que lhes proporcionasse uma experiência vital da Literatura. Para a época, poderíamos dizer que Osman Lins foi ousado em seu plano pedagógico, com o intuito de despertar nos alunos o amor que ele, como escritor, tinha pela Literatura.

Os dois grandes temas abordados por Osman Lins nas aulas de Teoria Literária são as dificuldades enfrentadas pelo escritor e a discussão dos elementos estruturais da narrativa, ligada ao seu próprio processo de criação. O primeiro tema reflete a sempre presente preocupação de Osman 
Lins quanto à necessidade de uma profissionalização da atividade do escritor, preocupação abordada com veemência na sua obra ensaística, especialmente em Guerra sem testemunhas, mas também em numerosos outros textos publicados durante sua carreira. A segunda parte do curso constitui-se da conceituação de elementos da narrativa, com acentuado caráter de depoimento, na medida em que esses conceitos são exemplificados e fundamentados pela análise de suas próprias obras, seja de forma pontual com o uso de Os gestos e O fiel e a pedra, ou de maneira extensa e minuciosa, com Nove, novena e Avalovara. Em 1977, após essa experiência em sala de aula, Osman Lins publicará sua segunda obra ensaística, Do ideal e da glória: problemas inculturais brasileiros, contendo partes dedicadas à reflexão do Ensino Universitário.

É com base em suas aulas e suas duas obras ensaísticas que teceremos as considerações que se seguem.

\subsubsection{Os problemas e dilemas do escritor}

"Os problemas do escritor se configuram por uma luta entre ele e o exterior. Ele luta por sobreviver e afirmar-se." Osman Lins ${ }^{27}$

Fez parte da vida de Osman Lins, como da de poucos outros escritores, uma intensa e quase obcecada campanha pela dignificação da condição do escritor. São vários os seus embates: a formação do escritor; sua sobrevivência financeira; a exploração que sofre do mercado editorial; a inacessibilidade do leitor, a luta contra os meios de comunicação de massa, e a realidade social brasileira. Em 1969, um ano antes de tornar-se professor universitário, o autor publica Guerra sem testemunhas, livro de ensaios no qual esses temas são tratados incisivamente. Sobre o próprio livro, por ocasião de seu lançamento, Osman Lins declara, em entrevista concedida ao Jornal da Tarde:

Não escrevi este livro ou qualquer outro inspirado pelos deuses. Custou-me dois anos e meio de interrogações, estudo e esforço. (...) 
Posso dizer que o escrevi, antes de tudo, por me haver parecido chegada a hora de fazê-lo. Como diz o subtítulo, é uma obra sobre o escritor, a sua condição e a realidade social. (...) Mas deixo bem claro: essas meditações não se alçam às nuvens. Nascem do que tenho vivido e visto como escritor brasileiro, que tem em mira sempre a sua realidade. É portanto um livro de reflexão e de combate. De reflexão sobre o ofício de escrever: e de combate pelos valores do espírito, sem os quais a vida nada vale.

O livro certamente foi escrito do ponto de vista do escritor. É o que eu sou. O ponto de vista não poderia ser outro. Acontece que o destino dos escritores está ligado ao da sociedade em que vivem. Conclui-se que, ao depor e refletir, como escritor, sobre este meu ofício, estou na verdade depondo e refletindo igualmente sobre a sociedade em que existimos. (LINS: 1979 , p. 150)

Dividido em dez capítulos, a estrutura da obra apresenta-se da seguinte forma:

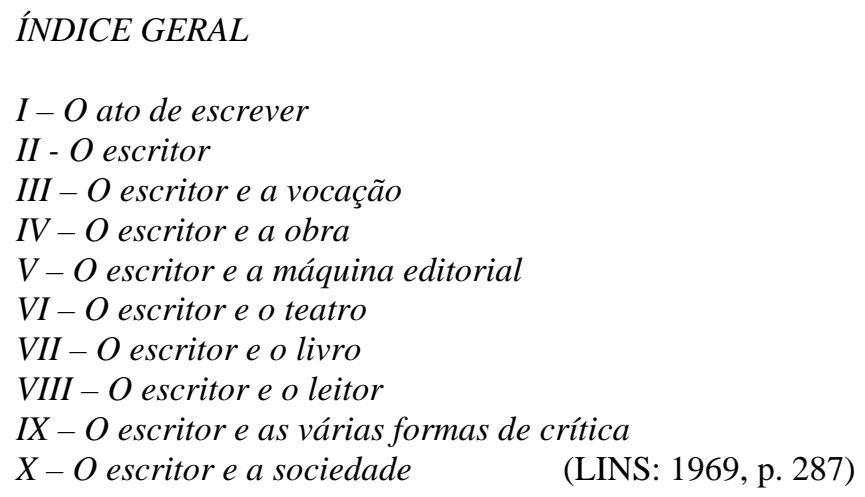

Também como professor de Literatura Brasileira, Osman Lins considera necessário não só discutir questões técnicas e conceituais sobre o fazer literário, mas também dar a ver a seus alunos aspectos sociais que o conformam. Assim, parte das aulas ministradas versará sobre temas ligados aos problemas do escritor, conforme nos atestam os itens elencados no material preparatório do curso:

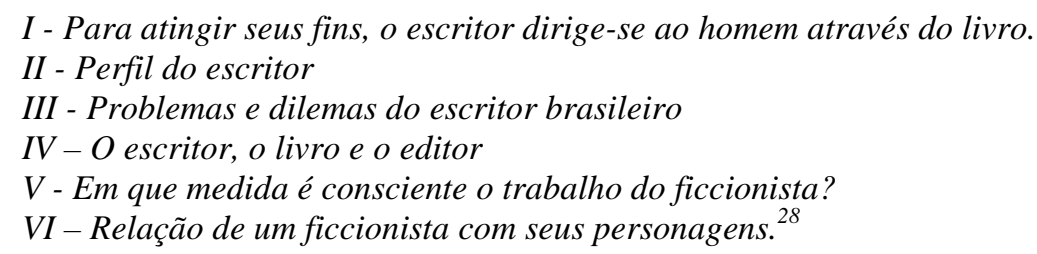

Percebemos a homologia temática entre obra e aulas. De maneira simplificada e não exaustiva, podemos relacionar alguns paralelismos:

28 Títulos retirados dos planos de aulas. Arquivo do Instituto de Estudos Brasileiros USP - Fundo Osman Lins. Código dos documentos: OL/MAG/Cx2/P2/04; OL/MAG/Cx2/P2/05; OL/MAG/Cx2/P2/06; OL/MAG/Cx2/P2/08; OL/MAG/Cx2/P2/10; OL/MAG/Cx2/P2/11 


\begin{tabular}{|l|l|}
\hline \multicolumn{1}{|c|}{ Aula } & \multicolumn{1}{|c|}{ Guerra sem testemunhas } \\
\hline $\begin{array}{l}\text { I - Para atingir seus fins, o escritor dirige-se ao } \\
\text { homem através do livro. }\end{array}$ & VII-O escritor e o livro \\
& VIII - O escritor e o leitor \\
\hline II - Perfil do escritor & I-O ato de escrever \\
& II - O escritor \\
& III -O escritor e a vocação \\
\hline III - Problemas e dilemas do escritor brasileiro & IV-O escritor e a obra \\
& V-O escritor e a máquina editorial \\
& X-O escritor e a sociedade \\
\hline IV-O escritor, o livro e o editor & V-O escritor e a máquina editorial \\
& VII-O escritor e o livro \\
\hline V - Em que medida é consciente o trabalho do & I-O ato de escrever \\
ficcionista? & IV-O escritor e a obra \\
\hline VI - Relação de um ficcionista com seus & I-O ato de escrever \\
personagens. & IV-O escritor e a obra \\
\hline
\end{tabular}

Aulas e ensaios dialogam de forma múltipla: uma aula pode referir-se a temas abordados em vários ensaios, assim como um ensaio pode relacionar-se com várias aulas. Além disso, nem aulas nem ensaios individuais restringem-se à discussão do tema inicial proposto. De maneira geral, todos eles apresentam uma linha argumentativa semelhante, uma espinha dorsal, que é retomada de formas diferentes e com exemplos diferentes a cada momento. A partir de agora, descreveremos essa linha argumentativa e exemplos de seu desenvolvimento nas aulas e nos ensaios, que, de certa forma, lhe serviram de base.

O primeiro ponto a se notar é que as aulas de Literatura não são lecionadas por um crítico alheio à criação literária, mas por um ficcionista atuante. Isso faz toda a diferença na formatação do curso e na visada dos temas e obras, como podemos verificar nas anotações preparatórias de uma de suas aulas:

Esclarecer: não sou mais professor.

Escritor. Alegria e respeito diante do seu Trabalho.

Devido, mesmo, em parte, a essa alegria e esse respeito é que está afastando-se do magistério.

Isto, portanto, nada tem de aula. ${ }^{29}$

Os ensaios, por sua vez, mostram o esforço de um escritor em refletir sobre sua condição profissional, buscando um reconhecimento pelo seu trabalho com a palavra escrita, ao mesmo tempo 
em que, de certa maneira depõe a partir de sua própria experiência e denuncia práticas externas que interferem em suas atividades literárias. Tudo isso está condensado no subtítulo da obra - Guerra sem testemunhas: o escritor, sua condição e a realidade social - sendo que, do próprio título, em especial, da palavra guerra, antecipa-se o embate que será travado no decorrer da composição e exposição de todo o livro. Sendo assim, neste princípio de análise, já nos fica claro a proximidade entre as aulas e os ensaios, pois ambos, com caráter testemunhal, trarão, tanto a alunos como a leitores, as fortes posturas críticas de Osman Lins.

No curso de Literatura, um dos primeiros esforços de Osman Lins é definir o que é um escritor e qual o seu papel na sociedade. Seu ponto de partida são citações de Bérgson, Proust, Shelley e outros, que ressaltam a importância do artista, do poeta e da poesia, como capazes de dar a ver o mundo real que se esconde por detrás do mundo convencional. No plano de aula Em que medida é consciente o trabalho do ficcionista $?^{30}$, Osman Lins define o escritor com suas próprias palavras:

(...) um indivíduo com todo o seu ser voltado para o mundo e como o mais capacitado a um exercício de lucidez. ${ }^{31}$

Como se depreende dessa formulação, estamos adentrando uma aula que tratará do processo criador; portanto, essa aula se inscreve no campo da Teoria Literária. É verdade que se trata de uma teoria literária que leva em conta a experiência do professor como criador:

Posição do escritor na comunidade: fonte de renovação. ${ }^{32}$

Resumindo, as idéias do professor Osman Lins podem dizer que ao verdadeiro escritor impõese um desafio de que ele não pode se esquivar: um “compromisso radical com a palavra escrita ${ }^{33}$ ”. Não diferente do discurso presente em Guerra sem testemunhas, em que colhemos a concepção osmaniana de como deve ser o escritor:

\footnotetext{
30 Arquivo do Instituto de Estudos Brasileiros USP - Fundo Osman Lins. Código do documento: OL/MAG/Cx2/P2/10

31 Arquivo do Instituto de Estudos Brasileiros USP - Fundo Osman Lins. Código do documento: OL/MAG/Cx2/P2/10

32 Arquivo do Instituto de Estudos Brasileiros USP - Fundo Osman Lins. Códigos dos documentos: OL/MAG/Cx2/P2/02-1; OL/MAG/Cx2/P2/07, OL/MAG/Cx2/P2/08. Salienta-se a repetição, coletada em três momentos diferentes do materaial de preparação das aulas.

33 Arquivo do Instituto de Estudos Brasileiros USP - Fundo Osman Lins. Código do documento: OL/MAG/Cx2/P2/06
} 
(...) sem o fazer deliberadamente, ilustro o postulado gideano, segundo o qual o escritor, longe de evitar ou ignorar suas dificuldades, nelas deve apoiar-se. (LINS: 1969, p. 11)

E também:

Mas contra os que pretendem fazer acreditar na existência de 'um mundo mágico da escrita' e a quem, confessando detestar, verbera de falsificadores, insurge-se J. P. SARTRE, assim coincidindo, por outras razões, com VALÉRY: 'Iludem aquêles que chegam e que êles entusiasmam para se tornarem também feiticeiros. Que os escritores comecem por renunciar ao ilusionismo'. (LINS: 1969, p. 13)

Esse compromisso com o árduo trabalho de composição é predominantemente formal: manipulação e renovação da língua, que está sempre sujeita a "enriquecimento e desgaste". Nas aulas, Osman Lins compara o escritor a um restaurador ${ }^{34}$ e "tal restauração opera-se através da escrita". Ao renegar esse desafio ou descuidar-se dele, o escritor passará a ser somente um escritor comercial. Nos ensaios, a figura de comparação será a do artesão: "nos inseríamos de um modo mais positivo em nossa condição de homens, de artesão do mundo" (LINS: 1969, p.50). ${ }^{35}$

Mas, uma vez assumido o compromisso mencionado acima, um dilema se propõe ao escritor: o que escrever? Na aula, essa dúvida estende-se ao gênero:

(...) “Que gênero de Literatura deverei tentar realizar?” A indagação não é sem importância, pois escrever é um ato de grande responsabilidade. ${ }^{36}$

E, posteriormente, a dúvida envolve a temática. Para dar conta do processo criador, em sua aula,

Osman Lins chama a atenção para as fases:

Consideremos a obra

ANTES DE INICIADA;

\footnotetext{
34 Nota-se aqui que dentro da aula de teoria literária, já há indícios da profícua comparação entre Literatura e as outras artes. O escritor é comparado ao restaurador, sendo este último, um profissional intimamente ligado à preservação e ao tratamento de objetos artísticos, sejam eles telas, esculturas ou patrimônios arquitetônicos.

35 A comparação entre o escritor e outros profissionais que lançam mão do delicado e minucioso trabalho manual não é exclusividade dos ensaios de Guerra sem testemunhas. Como exemplo, apontamos o texto Um Dia em que se Despede do Calendário, publicado originalmente em periódico, em 1976 e posteriormente na coletânea Evangelho na Taba (1979). Nele, a figura central é o alfaiate, profissão exercida pelo pai de Osman Lins. E é no ensaio que encontramos: “(...) seria de esperar que houvesse, não somente por essa atividade [alfaiataria], como por todas que exigem habilidade com as mãos e certo toque pessoal, interesse bem maior da parte do escritor, pois há um parentesco entre elas e o ofício de escrever.” (LINS: 1979, p.115).

36 Arquivo do Instituto de Estudos Brasileiros USP - Fundo Osman Lins. Código do documento: OL/MAG/Cx2/P2/06
} 
DURANTE.

\section{DEPOIS DE INICIADA}

ANTES Escolha do tema. Por que a escolha? Inspiração?37

São muitas as solicitações, mas poucas as escolhas.

Por que se escolhe isto? (O caso Humberto de Campos.)

Um chamamento, uma exigência, uma necessidade.

Chamamento de assunto?

Exigência da imaginação?

Necessidade interior?

Não. Chamamento da comunidade, exigência da nossa própria consciência, necessidade no sentido de ser preciso. 38

Vemos assim que o imperativo norteador da composição de uma obra é social e moral: compromisso com as necessidades da sociedade e com a própria consciência do escritor. Em Guerra sem testemunhas, o mesmo tema emerge:

Concede-se, em geral, no ficcionista, entidade dominante nestas cogitações, grande importância à imaginação, supondo-se que as suas obras mais bem realizadas coincidem com o pleno desenvolvimento da capacidade imaginativa. Imaginação. O têrmo se presta a várias interpretações. Aqui vai considerado sob a mais simples e difundida: a faculdade de inventar (figuras, emoções, incidentes, tramas). Êstes elementos acham-se presentes em quase todos os ficcionistas, mesmo entre os mais desorientados, os menos conscientes de seus rumos. A imaginação, realmente, atinge a plenitude à época das grandes criações de um escritor de ficção. (...) Portador de um plano - pois tem uma noção do mundo - e reorganizando sua experiência, ao invés de invocar os podêres da imaginação, trabalha com vistas a um rumo definido, num mundo com o qual está em contato e que, através do exercício da literatura, irá devassar para melhor conhecer. Sua plenitude não consiste em inventar mais; e sim inventar de modo significativo. (LINS: 1969, p.61)

Ainda assim as escolhas de um ficcionista não são óbvias nem pacíficas. E o exemplo disso

vem de um extrato de suas aulas:

(...) deverá o escritor sondar [a] realidade imediata, ou, conforme suas capacidades, interrogar de um dado mais amplo e talvez mais abstrato, a condição humana, a inserção do homem no mundo? A opção não é fácil, e o escritor, creio eu, nunca aplaca inteiramente a sua consciência. ${ }^{39}$

Como o assunto não é determinante para definir a obra literária, Osman Lins contemplará também os necessários aspectos formais:

Escolhido o assunto (ou assunto central) e identificada sua razão de ser, ainda resta, antes de iniciá-lo:

37 A respeito da inspiração, ver a entrevista Quando você ouvir falar em inspiração, desconfie. In: Jornal da Tarde - SP, 16/05/1969. Publicada postumamente em Evangelho na Taba: outros problemas inculturais brasileiros (1979).

38 Arquivo do Instituto de Estudos Brasileiros USP - Fundo Osman Lins. Código do documento: OL/MAG/Cx2/P2/10

39 Arquivo do Instituto de Estudos Brasileiros USP - Fundo Osman Lins. Código do documento: OL/MAG/Cx2/P2/06 
estabelecer o plano;

o esquema;

em certa medida, a extensão;

etc. $^{40}$

Em outras palavras, o planejamento de uma obra, mas do que uma estrutura rígida, novamente demonstrará a necessidade de compromisso e dedicação de seu autor. Mais do que idéias soltas e esboços, o escritor passará por etapas de elaboração muito bem definidas, seguindo tanto os critérios apontados nas aulas, como procedimentos colhidos nos ensaios:

Executar uma obra está diretamente ligado a concebê-la; e concebê-la quer dizer empreendê-la com clarividência, atribuir-lhe um plano que seja ao mesmo tempo as balizas de um roteiro a executar e uma súmula de seu conteúdo espiritual. Isto não significa que um plano tenha de ser cumprido, no sentido que se segue o programa de uma convenção de vendedores. Muito mais rígido, por sinal, é o esquema. (...)

Mas o esquema ou o plano, quando surgem, vão coincidir com uma fase em que, no espírito do autor, a obra possível já cumpriu um itinerário secreto (...). (LINS: 1969, p. 61)

Entretanto, não só de planejamentos e técnicas viverá o ficcionista. Para que o escritor possa alcançar uma posição ideal para exercer sua função, ele deve superar quantidade não desprezível de obstáculos e, nesse momento, o professor alerta seus ouvintes:

Para escrever, [o escritor] terá de entregar-se a grandes sacrifícios. Cada página, representará um sacrifício. ${ }^{41}$

Em Guerra sem testemunhas, há o alerta para a dedicação e o esforço no ato de escrever:

Dificilmente, mesmo na maturidade, consegue o escritor dar um caráter definitivo às primeiras páginas escritas de um trabalho que se prevê extenso. Estas, na maior parte dos casos, são mais do que qualquer outra coisa, um interrogatório, uma procura, a tentativa de encontrar o fio da obra, enovelado em nossa mente. (...) Tão incertos buscamos nosso rumo, que os vários trechos do trabalho se anulam mutuamente. Não concluímos ainda o capítulo segundo e já sabemos que o primeiro tem de ser refeito; refazêmo-lo, escrevemos o terceiro; passam os dois outros a carecer de sentido; voltamos a êles; saltamos para o quarto capítulo, para constatar que os anteriores já não servem (...). (LINS:1969, p. 65)

Um dos problemas de base é a formação do escritor. A sociedade, em geral, não fornece condições para que o indivíduo possa consciente e proficuamente escolher e dedicar-se a esse ofício, 
muito menos encontrar cursos ou ambiente de formação apropriados. Em Do ideal e da glória: problemas inculturais brasileiros, Osman Lins fará crítica à interferência dos pais na carreira dos filhos e à marginalização das profissões ligadas à arte e à cultura:

(...) olho com ceticismo e talvez com ironia os famosos planos, hoje em moda, destinados a desenvolver a criatividade, principalmente nas crianças. (interessante, a esse respeito, notar que os pais exultam com as criações dos filhos, do mesmo modo que alegremente os enviam para os cursos de ballet. Mas nunca aceitam que essa mesma criança, mais tarde, faça da poesia ou do ballet sua razão de viver.) (LINS: 1977, p.75)

Em Guerra sem testemunhas, a escolha de ser escritor é apresentada de maneira muito mais patológica, e palavras como vocação, possessão, obediência e destino são lançadas, como defensoras do sentimento incontrolável de seguir a carreira dedicada a algo que difere dos tradicionais padrões sociais.

(...) o homem que acredita obedecer à sua vocação, só com maturidade podia alcançar a natureza e o sentido da atividade a que se consagra. Dêste modo, aceitar os pressupostos da vocação significava conceder transcendência factícia a um rumo tomado mais ou menos às cegas. O indivíduo era possesso por uma vocação, o mesmo modo que outros pelos maus espíritos. (...) (LINS: 1969, p. 48)

Quando o homem admitia ser o instrumento de uma vocação, vinha ampliar o número dos que - com a mesma tendência de parecerem ligados a instantes e dúbias realezas - diziamse guiados, na composição de seus livros, pelo sôpro da inspiração. Quando, pelo contrário, recusávamos ser o portador, o executante de uma vocação, quando - bem ou mal escolhíamos, definindo-nos perante nós mesmos, ampliávamos o papel da consciência (...) na elaboração de nosso destino (...). (LINS: 1969, p. 49)

Poderia (...) atribuí-lo à tentação do demônio. Mas o demônio era exorcizável; não as vocações. (LINS: 1969, p. 50)

Em sua produção ficcional ${ }^{42}$, no conto “Apólogo do herói bem conduzido"43, publicado inicialmente em periódico, Osman Lins apresenta a história de um homem que, ao seguir os padrões sociais impostos desde seu nascimento, vê-se aparentemente bem-sucedido em uma profissão que não lhe tem o menor significado e por isso, torna-se infeliz consigo mesmo:

\footnotetext{
42 Cabe indicar também o conto "A partida", de Os gestos, que, declarado pelo próprio Osman Lins como autobiográfico, relata a saída de casa de um jovem, em busca de seus sonhos e de uma vida diferente da oferecida na pacata cidade onde mora com a avó.

43 Ver transcrição do conto em ANEXO 4. Posteriormente, com sutis adaptações, foi publicado com o título "Confissões de um Brasileiro de Hoje", também presente na coletânea Evangelho na taba: outros problemas inculturais brasileiros (1979).
} 
(...) saí da faculdade, vi que existia toda uma legislação à minha espera, pronta para guiar-me os passos, proteger-me e evitar que me sobreviesse algum infortúnio. Eu tinha a idéia, é certo que um tanto vaga, de fixar-me no litoral; mas fui enviado para o Oeste, o que foi - confesso - uma surpresa, pois eu nunca pensara que nosso país tivesse Oeste.

Tudo que eu devia fazer fora estabelecido há muito tempo. Aliás, eu aprendera, na Faculdade, com o catedrático de Imobilismo Estrutural, que não devia propor nenhuma idéia nova ou ensaiar qualquer alteração nas organizações para as quais eu fosse nomeado, cuja perfeição e cuja continuidade, em grande parte, dependeriam do meu silêncio.

(...)

A certa altura, eu andava cansado, aborrecido, procurando não sabia o quê e me ocorreu que talvez fosse bom ficar desempregado uns tempos. Pedi demissão. Não me foi concedida.

Nas anotações de aulas, essa mesma preocupação reaparece, primeiro revestida de uma análise mais abrangente sobre a educação no Brasil:

Grande é o número de jovens que, ao concluírem os seus preparatórios, ignoram a carreira que haverão de seguir. Muitos se deixam levar pelas indicações paternas, enquanto outros, se têm condições para continuarem os estudos, matriculam-se em não importa que curso, um pouco às cegas. $\mathrm{O}$ número dos que fazem realmente uma opção é pequeno. 44

Em outro momento, segue-se uma breve constatação sobre o modo como a Literatura e o escritor são vistos pela sociedade:

4. Duas observações sérias:

a) não somos um país de literatos;

b) vê-se que tende a agravar-se: o escritor entre nós, sendo cada vez mais um ser extravagante, suspeito ${ }^{45.46}$

Voltando aos ensaios, com certo caráter de depoimento pessoal, por hora travestido de personagens ou analogias, Osman Lins dará seu recado: o escritor, diante de suas escolhas, estará marcado na sociedade ocidental contemporânea. E, de forma comparativa, aponta que em sociedades nas quais o místico e os fenômenos naturais são usados como sinais de distinção dos indivíduos, a responsabilidade do artista torna-se muito mais branda. Nesse caso, ele argumenta apontando os estudos de Margareth Mead:

Ele próprio, ao enveredar ainda bem jovem pela literatura, acreditava atender a um chamado imperioso e a este não podia negar-se. A idéia não lhe fôra imposta. Não lhe sucedera como aos Mundugumor, povo da Nova Guiné, estudado por MARGARETH MEAD. Crêem que

\footnotetext{
44 Arquivo do Instituto de Estudos Brasileiros USP - Fundo Osman Lins. Código do documento: OL/MAG/Cx2/P1/02

45 Lembremos que o termo "suspeito" usado aqui tem ligação direta com o regime ditatorial vigente no Brasil, na época em que Osman Lins atua como escritor e professor.

46 Arquivo do Instituto de Estudos Brasileiros USP - Fundo Osman Lins. Código do documento: OL/MAG/Cx2/P2/12
} 
as crianças "lançadas", ou seja, as que vêm ao mundo com o pescoço envolvido no cordão umbilical, trazem com isso o signo de seu destino: serão artistas. O surpreendente é que, segundo M. MEAD, citada por VIOLA KLEIN 'somente os que nasceram assim podem pintar bons quadros, enquanto que o homem dado à luz sem o cordão estrangulador trabalha humildemente e sem arrogância e jamais alcança o mínimo grau de virtuosismo.' (...)

$\mathrm{Na}$ sociedade em que vivemos, evoluída e diferenciada, a pressão exterior não previa o destino de seus membros, ou de alguns dêles, com a exatidão e a reduzida escolha dos Mundugumor. (...) (LINS: 1968, p. 48)

Tornávamos um pouco mais próxima de nós aquela vida sonhada em que o homem, sem negar o mistério de sua condição, viria a instaurar-se com fé e confiança na fruição de suas liberdades e na aceitação de suas responsabilidades.

A resposta do jovem recifense era expressiva também sob êste ângulo. (LINS: 1969, p. 50)

Quando estão superados os problemas iniciais de vocação e formação, é que se apresenta ao escritor uma verdadeira obsessão: como fazer sua obra chegar ao público leitor? Nesse instante, o escritor passa a ser vítima de três grandes problemas da sociedade moderna: a tirania do mercado editorial, a tibieza do ambiente cultural e as deficiências educacionais. Aos alunos, é feito o alerta:

Deixemos de lado a fase da aprendizagem inicial e da confecção da obra. Aproximemo-nos do escritor no momento em que ele conclui o seu livro: e começa a carreira.

Procura do editor. Por quê? A tríade OBRA-EDITOR-LEITOR. Os dois extremos não se encontram, sem uma mediação eficiente. ${ }^{47}$

Alvo de duras considerações, o editor surgirá nos depoimentos de aulas, como um grande vilão na vida de um escritor. Da mesma forma que Osman Lins discute o ofício de escritor, o processo de formação profissional do editor também será debatido com seus alunos:

Curso de Editoração. Não se circunscreve apenas à fabricação de livros. O homem da edição deve entender de livros como produto industrial e também de textos.

livros. Necessário um conhecimento do mercado, das técnicas de distribuição e venda, da fabricação do livro e também xxxxxxxxxxxxxxxxxxxxxxxxxxxxx uma intimidade com o texto literário. ${ }^{48}$

Entretanto, o perfil de um editor esperado por Osman Lins não se reflete na sua própria experiência:

(...) A atividade literária, assim concebida, liga-se estreitamente ao problema da editoração: posição do editor diante da obra nova. O editor: existir para o autor - ou seja, para a comunidade - e não contra o autor. ${ }^{49}$ 
Segundo Osman Lins, o editor, em regra: nem sequer lê a obra, e muitas vezes, cobra pela avaliação; tende a evitar contratos ou apresentar contratos absurdos; mostra pouco empenho na divulgação e distribuição da obra publicada..$^{50}$

Em Guerra sem testemunhas, vemos os mesmos argumentos e um desabafo:

Esta confissão, não habitual em obra literária, serve para introduzir (...) o tema da distância existente (...) entre o ato de escrever o livro e o de publicá-lo, entre o escritor e o editor. Ao primeiro cabe escrever o livro; ao segundo, editá-lo e vendê-lo. (...) Flagrante contraste: de um lado, o indivíduo isolado, arriscando pouco ou nada; de outro, a emprêsa, o vultuoso capital, o risco em grande escala, o perigo da concordata e até o da falência.

Não deixa de ser compreensível que o problema venha sendo colocado sempre em têrmos de rigorosa dependência no que se refere ao escritor e de quase munificência no que diz respeito ao editor. Êste, que arrisca seu dinheiro para estruturar e movimentar uma complexa emprêsa de índole cultural, quando podia fazê-lo em muitas outras, lucrando bem mais, já é por si mesmo um benfeitor, um divulgador de cultura, merecendo portanto a gratidão geral. (...) Para manter-se, porém, no agradável papel, tem 'essa espécie de Minotauro da Arte' (...) de defender-se contra os prejuízos, editando obras lucrativas, que acelerem a prosperidade da emprêsa, firmando sempre mais a sua permanência. (...) Política inevitável (...). Geratriz, todavia, de um paradoxo digno de meditação e em virtude do qual o negócio do livro assume dúplice caráter, responsável por muitas incompreensões e também por muitas inverdades: o editor, enquanto reivindica o papel de agente cultural, tende a ver na obra literária um objeto de lucro, industrializável, avaliado antes de tudo segundo as possibilidades comerciais que possa oferecer. Essa avaliação, em princípio, elimina os livros demasiados grandes (pela dispendiosa produção), os demasiados pequenos (por não representarem um negócio digno de atenção), os autores desconhecidos, assim como toda e qualquer obra literária que, pela sua novidade, implique em um nôvo tipo de leitura, e portanto de leitor, e portanto de público, de modo que editá-la constitui para a emprêsa um ato anômalo, pois (...) financia e entrega o produto a um consumidor que não existe (...). (LINS: 1969, p. 81-83)

Além da máquina editorial, que dificulta o aparecimento de novas obras e autores e não valoriza e impulsiona os autores publicados, um outro óbice que se coloca entre o autor e o leitor são os meios de comunicação de massa, pois, por sua natureza, eles competem com o livro. Em esquema de aula, vê-se:

(...) [o] homem é atingido diariamente, por grande massa de informações padronizadas. Industrializadas.

TV

Rádio

Cinema

(...) A industrialização tende para o consumo rápido e, se possível, imediato.

(...) Assim, no bojo da própria expansão, encontra-se um inimigo do livro, da literatura.51

50 Vale ressaltar que a análise parte de um escritor dedicado à busca pela publicação de sua obra, entre os anos de 1960 e 1970. As mudanças da legislação brasileira, os avanços tecnológicos e o novo perfil do mercado editorial de hoje modificam o atual cenário e trazem novos benefícios e novos questionamentos, que não cabem aqui ser analisados.

51 Arquivo do Instituto de Estudos Brasileiros USP - Fundo Osman Lins. Código do documento: OL/MAG/CX2/P2/04 
Em Guerra sem testemunhas, de maneira mais prolixa, reforça-se:

Expande-se o livro. Ao mesmo tempo, um fôsso cada vez maior e do qual urge tomar consciência, caracterizando-o, aprofunda-se em tôrno do escritor. Walt Disney é 'consumido' em mais de trinta países suas edições só no Brasil, alcançam as tiragens de 80 a 100 milhões de exemplares por ano. O mais expressivo programa de TV atinge um público muitas vêzes superior ao abrangido por qualquer romance, ainda que êste obedeça às receitas correntes. Por isto vêem alguns, nesses novos meios expressivos, o dissolvente por excelência da literatura. (LINS: 1969, p. 248)

Para Osman Lins, não só da propagação de produtos culturais de baixa qualidade são responsabilizados os meios de comunicação em massa, mas também de induzirem o indivíduo (em especial, o artista) ao consumo de "um novo produto da civilização industrial: O SUCESSO. ${ }^{52 " ~ A ~}$ busca cega pelo êxito também se torna um inimigo da Literatura, pois bate de frente com o ideal proposto para o verdadeiro escritor, já mencionado anteriormente, que é escrever segundo sua própria consciência e segundo as demandas (ocultas) da sua comunidade, além de gerar expectativas errôneas para o escritor que nem sempre saberá lidar com o fracasso.

Premido pela difícil relação com o mercado editorial e competindo de forma desigual com a indústria cultural, a distância entre escritor e leitor se exacerba ainda por mais um motivo importante: os entraves educacionais e culturais, frutos da realidade social brasileira, que se manifestam, por exemplo num analfabetismo, ou na própria inexistência de um público leitor significativo capaz de consumir uma literatura de maior qualidade.

\footnotetext{
Ora, a realidade brasileira, em relação à obra literária, oferece um quadro melancólico: há uma burguesia que não lê; e uma massa anônima que não tem condições de ler, seja por falta de instrução, seja por falta de numerário. - Uma literatura mais elementar poderá ainda alcançar, na horizontal, uma faixa mais ampla. Uma literatura mais elevada, ao contrário, só poderá ser recebida por uma faixa restrita e, justamente, quase sempre, a mais bem colocada na sociedade. ${ }^{53}$
}

O Brasil da década de 1970, dono de um quadro social resultante de uma história nacional baseada na exploração e no privilégio, vive, ademais, uma situação particular: a ditadura, na qual uma das principais instituições é a censura. Esse inimigo pontual também será articulado na crítica osmaniana, feita em sala de aula. 
Um decreto ainda recente estabeleceu no Brasil a censura prévia para revistas e livros. Escrever, nos países pobres, atividade cada vez mais dramática. ${ }^{54}$

E completa que, mais aviltantes que a própria censura são, para Osman Lins, os autores e compêndios de gramáticas:

(...) 2 inimigos continuam a perseguir a obra literária:

A CENSURA

$\mathrm{E}$

OS AUTORES DE GRAMÁTICAS.

(...)

Muito pior do que a censura: os compêndios. ${ }^{55}$

Frente a todos esses inimigos identificados - o editor, a indústria cultural, a realidade social brasileira, a censura e os compêndios -, que inviabilizam seu trabalho e o acesso ao leitor, o escritor vê ameaçada a sua própria sobrevivência, caso deseje insistir numa atividade não oficializada, não valorizada e mal remunerada. Assim, marginalizado, é obrigado a aceitar outros empregos para obter seu próprio sustento:

Torna-se quase impossível a evolução normal do escritor. Mal recompensado, trabalha nas horas vagas.

Duas tendências compensatórias: a oficialização e a aceitação de atividades paralelas. ${ }^{56}$

A solução mais comum é um meio-têrmo, uma meia-saída: um pé na Literatura e outro numa profissão qualquer. Na atual estrutura empregatícia no Brasil, cada vez mais propenso a absorver de maneira total o empregado, tal solução conciliatória torna-se cada vez mais difícil. $^{57}$

Na aula Depoimento sobre a técnica e a experiência, Osman Lins apresenta sua profissão de fé:

(...)

$1^{\circ}$ Por que escrever?

- Investigar o Universo.

- Explorar o campo de possíveis da LITERATURA.

Isto é:

Não transmitir, com métodos tradicionais, uma visão nova das coisas; mas

54 Arquivo do Instituto de Estudos Brasileiros USP - Fundo Osman Lins. Código do documento: OL/MAG/Cx2/P1/04 
criar uma obra que seja através dos seus meios expressivos, esta visão nova posta em termos romanescos. ${ }^{58}$

E nos ensaios de Guerra sem testemunhas, apenas encontra-se o eco reforçando o que Osman Lins executa em seu próprio processo de criação:

Sem uma concepção do mundo que enseje planificar - com base em princípios talvez não absolutamente claros - sua obra futura; sem uma justa visão do fato literário; e sem ter com o mundo um comércio que o induza a exercitar sua imaginação com o fito de representar, em têrmos romanescos, o mundo visto por êle, por êle experimentado, depreende-se que o autor embrionário se ponha nessa fase em uma posição de perplexidade e desgovêrno perante a obra a ser (talvez) escrita. (LINS: 1969, p. 63)

O questionamento inicial abre o mote para a vocação do escritor, paralelo à justificativa da escolha pela dedicação à palavra escrita. Segunda a anotação de aula da nota 58 , será por meio da Literatura que o escritor, um profundo curioso, explora um campo infinito de possibilidades de criação. A Literatura, como ferramenta, será a lente pela qual o escritor apresentará o universo, sendo que, muito mais explícito que em suas aulas, estará no plano literário de Osman Lins o verdadeiro depoimento do que aqui é teorizado. Tomando sua obra para demonstração do que até aqui foi dito, vemos como se manifesta o reflexo de uma postura consciente do seu fazer literário inaugurado por Nove, novena. A partir de Nove, novena Osman Lins passa a empregar uma linguagem em que os meios expressivos também são novos:

(...) fui procurando uma literatura que desse uma idéia de flutuação. Consegui isto em Nove, novena Geralmente um livro tem um ponto de observação. Ou é o narrador ou o personagem central que vai mostrando tudo ao leitor. O leitor se coloca neste ponto. Em Nove, novena diluí esse ponto com os sinais gráficos que ajudam a intercalar os diálogos. Mas os sinais gráficos são apenas um acidente. Eles são importantes apenas enquanto servem de instrumento para o que vou escrever. (LINS: 1979, p. 149)

Até então, Osman Lins limitava-se ao uso de métodos tradicionais para a transmissão da "visão nova das coisas". Nos contos de Os gestos (1957) e nos romances $O$ visitante (1955) e O fiel e a pedra (1961) o escritor pernambucano inicia suas experiências narrativas na arte literária, sem grande 
ousadia diante da forma. Em prefácio à edição de 1975 de Os gestos, o próprio escritor, já tendo tido novas experiências, deixa claro suas influências tradicionais e seu caminho de formação:

Quando escrevi os contos aqui reunidos, todos alusivos ao tema da impotência do ser humano (...), minha ambição centrava-se em dois itens:

a) lograr uma frase tão límpida quanto possível;

b) não alheio à voz de Aristóteles, fundir num instante único, privilegiado, os fios de cada breve composição, como se todo o passado ali se adensasse.

A luta que, desde a adolescência, eu mantinha - sempre derrotado e às cegas - com a arte de narrar encontrava finalmente um rumo e, parece, uma resposta. Fazem parte da breve coletânea algumas das primeiras páginas que, após mais de dez anos de exercício constante, atingiram certo equilíbrio. Embora não seja o meu livro de estréia, a maior parte dos trabalhos nele presentes já existiam quando publicado $O$ visitante, na origem um conto a mais no volume e que, para espanto do autor, avultou-se e se definiu como romance. Sintome, por isso, ligado de maneira muito especial a Os gestos.

Nele, contudo, outro fator me atinge: como escritor, ainda havia em mim, quando o compus, uma brandura que não mais existe (...).

Olho, portanto, os treze contos da série (...) como se me visse em outro tempo, eu ainda não transformado pela realidade que me cerca e que, numa fórmula breve, confesso não armar e não admirar.

Se o leitor, por acaso, comparar este livro com Nove, novena, elaborado bem depois, poderá sem esforço atestar o que acima afirmei e talvez incline-se por este volume, nada obstante certo aroma soturno que, aqui e ali, dele se desprende. Não sentimos nós, tantas vezes, depois de contemplar, por exemplo, as crispadas expressões da pintura mais identificada com o nosso tempo, certo prazer em mergulhar nas paisagens e rostos de uma arte mais pacífica - como a de Botticelli? Isso, não porque recusemos a verdade. E sim, acho eu, por pressentirmos que o homem tem direito a um gênero de vida diferente deste que nos cabe e onde a inocência, em qualquer das suas formas, não viesse a converter-se numa espécie de crime. (LINS: 1994, p. 7 e 8)

Apesar da longa citação, lança-se mão dela, pois, no trecho apresentado, muitos aspectos evocam o presente estudo: seu caráter testemunhal, a relação entre a Literatura e as outras artes, o consciente percurso literário traçado por Osman Lins, a análise de sua própria obra (aspecto latente em sua atuação como professor) e o empenho diante do trabalho com a palavra, evidenciada nos longos anos de dedicação a produção de uma obra. Outro aspecto importante e já referenciado em outros momentos é a questão das fases de amadurecimento do escritor frente ao seu fazer literário e aqui, veremos que a preocupação do jovem Osman Lins centrava-se em "lograr uma frase tão límpida quanto possível". Em O fiel e a pedra, será o momento de ir um pouco além, tomando como base o cenário regional, mas afastando-se das características tipicamente regionalistas, tão em voga na Literatura da época. Com ecos da estrutura da epopéia, ganham vozes os personagens de seu romance: “(...) O fiel e a pedra, essa tentativa de transposição, para o Nordeste de 1936, da Eneida. Não propriamente uma transposição, uma vez que muitos personagens e fatos apresentados tem origem na 
minha experiência. Mas a verdade é que o romance, já iniciado, foi replanejado tendo em vista o poema de Virgílio".

Novamente tomando as anotações de aulas, sobre a questão o que escrever?, Osman Lins revela dúvidas e inseguranças que sempre o acompanharam:

Como nasce um romance? Por que escolhemos tal tema? Como nasce, nunca se sabe. Assemelha-se ao nascimento de uma paixão. [O Vento na Vila59]. Mas sempre podemos saber por que tal tema nos seduz. O visitante, pela impotência. O Fiel, pela potência.

Quando somos principiantes, necessário grande esforço da imaginação, para descobrir temas e trabalhá-los. - Aos poucos, vai a vida assemelhando-se à nossa ficção, pois vamos sendo impregnados pelas nossas visões. - Então ...

... o problema da procura é substituído pelo da escolha. CAMINHAMOS TAMBÉM PARA UMA PROGRESSIVA ACEITAÇÃO DA REALIDADE.

$E$ a imaginação passa a ter um papel retificador e ordenador. 60

Nos ensaios de Guerra sem testemunhas, as questões também se fizeram presentes:

Pretendendo seguir, nestas considerações, quando possível, a obra desde a origem, uma pergunta se impõe: 'Quando nasce?' Ninguém sabe. A experiência literária não é muito comum. A do amor, porém, conquanto raramente vivida em sua plenitude, é por assim dizer universal. Todos os que chegaram a conhecer em menor ou maior grau, do amor, os 'domésticos venenos' (CAMÕ̃ES) sabem que êle não surge com relâmpagos. Medra em nós, sutil, e de tal modo que nas relações amorosas qualquer data é fictícia. Ou melhor, não assinala começos, e sim o término de ciclos cujo verdadeiro início é ignorado. Igualmente vão nos empenharmos em buscar, no espírito, o momento em que nasceu determinada obra. (LINS: 1969, p. 59-60)

E quanto ao dilema escrever sobre a realidade imediata versus interrogar a condição humana no

mundo, Osman Lins, claramente, elege a segunda opção:

Uma mente (...) voltada para as sínteses e para $\operatorname{xxxxxxx~a~contemplação,~dificilmente~}$ poderia renunciar a isto, em favor de uma atividade/ que já seria política. Por outro lado, tenho uma noção das minhas fôrças e das fôrças que regem a nossa sociedade - e sei bem que não teria possibilidade de mudar sensivelmente as coisas. Limito-me, então, a contemplar o mundo e o meu povo, testemunhando sobre o nosso estar no mundo e permitindo que a compaixão xx e a cólera se introduzam, como um veneno ou um escorpião, nos meus escritor. 61

59 Apesar das tentativas de levantamento, não foi possível indicar se a referência se trata de um livro, um filme ou uma peça de teatro. 60 Arquivo do Instituto de Estudos Brasileiros USP - Fundo Osman Lins. Código do documento: OL/MAG/Cx2/P2/15. É importante ressaltar o diálogo entre a presente nota e a citação (LINS: 1994, p. 7 e 8), localizada na página 39 do presente trabalho.

61 Arquivo do Instituto de Estudos Brasileiros USP - Fundo Osman Lins. Código do documento: OL/MAG/Cx2/P2/06. Novamente o diálogo e a complementação de idéias, traça-se entre esta nota e a citação (LINS: 1994, p. 7 e 8), localizada na página 39 do presente trabalho. 
Tal observação deve ser lida com cuidado. De fato, o perfil do escritor Osman Lins é de um $\operatorname{artesão}^{62}$, preocupado em alto grau com a arquitetura narrativa e os meios expressivos de suas obras. Portanto, a recusa incisiva de uma Literatura engajada naquilo em que ela se aproxima de uma Literatura proselitista é totalmente coerente com esse perfil. Isso não quer dizer, no entanto, que, mesmo nas obras mais herméticas, as quais realmente sondam de maneira mais abstrata a condição humana, não exista, de forma subjacente, uma apropriação de dados e problemas da realidade imediata. Em entrevista concedida ao Jornal do Comércio, em 1978 e publicada postumamente em Evangelho na Taba, Osman Lins declara:

Se um artista quer engajar-se politicamente, é problema dele. Pessoalmente, acho o engajamento artístico limitador, pelo fato do artista dar à sua obra, a priori, uma determinada direção. Que dizer: ela não oferece surpresas, nem mesmo para o seu criador. Mas, não vamos supor, inversamente, que o não engajamento garanta a validade artística da obra. Hoje cobra-se muito do artista esse engajamento. Mas essa cobrança, em geral, não é feita por grandes artistas, e sim por pessoas fora desse métier ou por artistas secundários. Ainda: por pessoas geralmente ligadas às instituições, à universidade. Ligadas ao sistema. $\mathrm{Eu}$, para ser inteiramente livre e coerente, afastei-me de tudo isso, inclusive do magistério superior. Mas se penso que a obra não deva ser comprometida, acho também que o artista, como homem, como cidadão, não pode omitir-se dos problemas sociais. Essa distinção deve ser feita.

A Rainha dos Cárceres da Grécia foi submetido às ocorrências dos dias em que estava sendo escrito. Fatos noticiados nos jornais, acontecimentos pessoais, etc., alteravam a linha do romance, como podem observar os leitores. A Rainha é um romance exposto, declarada e deliberadamente, às pressões do cotidiano. Detesto fórmulas. Não aceito fórmulas. Meu lema é: explorar. (LINS: 1979, p. 265)

Em aula, no que se refere a sua formação, Osman Lins testemunha o seu itinerário:

(...) Não fiz curso de Letras e sim Economia e Finanças. ${ }^{63}$

Sua preparação:

Formação: leitura e exercícios de redação, [inclusive mentais]. Leituras: ficção e ensaios de interesse geral; relativamente pouca teoria e pouca psicologia. ${ }^{64}$

Suas primeiras influências:

62 Expressão usada também por Marisa Balthasar Soares, no artigo "No Arquivo do Artesão", publicado na Revista Cult, número 48, julho/ 2001.

63 Arquivo do Instituto de Estudos Brasileiros USP - Fundo Osman Lins. Código do documento: OL/MAG/Cx2/P2/28

64 Arquivo do Instituto de Estudos Brasileiros USP - Fundo Osman Lins. Código do documento: OL/MAG/Cx2/P2/28 
Primeiras admirações: os autores de tendência naturalista veritá: Flaubert, T. Dreiser, Tolstoi. - Não tardando que se acrescentassem os grandes ancestrais: Homero e Sófocles (Édipo Rei), depois Virgílio. ${ }^{65}$

Tal como denunciado por ele próprio, a formação de Osman Lins não passa por um curso específico e direcionado, sendo eminentemente autônoma, baseada na sua intuição, dedicação e modelada em escritores canônicos. Essa realidade permitirá que Osman Lins atribua ao próprio Curso de Letras um papel de guia para outros escritores:

[os escritores] não encontram em geral apoio de espécie alguma.

Conseqüências disto: enfraquecimento da Literatura e tendência à esclerose.

Importância, neste sentido, dos Cursos de Letras. ${ }^{66}$

A dificuldade de alcançar o público leitor também é exposta numa perspectiva pessoal. Primeiramente atribuída aos problemas com editores:

Procura-se editor. [Que é o editor?] Nem sequer lêem. As respostas.

Como deveria ser: comissão de leitura. Episódio da Martins: Não Aceitamos Originais - e CR\$ 300,00 para ler. ${ }^{67}$

Apesar de ser considerado inicialmente um inimigo do escritor e da Literatura, os meios de comunicação em massa podem ser aproveitados pelo escritor:

Que devemos fazer?

Não colaborar em caráter permanente com rádio, TV, cinema industrial. Entrar nesses campos, mas como SABOTADOR.

$(\ldots)^{68}$

Osman Lins apresenta tais argumentos com autoridade, visto que, em 1951, envolveu-se na direção e produção de programas radiofônicos culturais, na Rádio Jornal do Commercio de Recife. 
Para a TV, de 1975 a 1977 adaptará para o programa Casos Especiais, produzidos pela Rede Globo, as narrativas A ilha no espaço, Quem era Shirley Temple? e Marcha Fúnebre ${ }^{69}$.

Adaptar a obra a outros meios, certamente, não era uma ação inocente. Além da necessidade de complementação financeira e da tentativa de atrair novos leitores para sua literatura, existe em Osman Lins o ideal de propagar boa cultura no seio do que ele considerava cultura industrializada. O êxito nos moldes oferecidos pela sociedade do espetáculo também não seduz Osman Lins. Seu objetivo na conquista de um público leitor passa novamente pela sobrevivência financeira, e pela tentativa de contribuir para uma melhora das condições sociais por meio da Literatura.

Por falta de reflexão (talvez não de caráter) certos escritores buscam o "êxito", que é também um inimigo da literatura. ${ }^{70}$

Também o seu inconformismo pessoal em relação ao público para o qual ele precisa escrever transparece de maneira saliente:

Escrever, nos países marcados por grandes injustiças sociais, torna-se cada vez mais uma atividade dramática e difícil. Uma minoria detém os privilégios; quanto à maioria, lutando por sobreviver, iletrada (no Brasil, por exemplo, há hoje 30\% de analfabetos), faltam-lhe condições para chegar aos livros. O escritor vê-se privado do único público que desejaria, sendo lido apenas - quando é, pela classe que despreza. ${ }^{71}$

Já a censura, segundo o professor-escritor, poderia, na prática, contornada, pois ela é frágil diante de obras que conseguiram, por meio de sua linguagem, enganá-la :"Orientar-se pela censura e ludibriá-la. O Berço do Herói ${ }^{72}$, Viva Maria ${ }^{73774}$. O próprio Osman Lins consegue isso com Avalovara, a partir do momento que Olavo Hayano pode ser considerado um arquétipo da opressão militar. E,

69 Vale ressaltar que postumamente, em 2003, sua peça Lisbela e o prisioneiro foi adaptada ao cinema.

70 Arquivo do Instituto de Estudos Brasileiros USP - Fundo Osman Lins. Código do documento: OL/MAG/Cx2/P2/04

71 Arquivo do Instituto de Estudos Brasileiros USP - Fundo Osman Lins. Código do documento: OL/MAG/Cx2/P1/04

72 Deduz-se que Osman Lins faz referência à peça $O$ berço do herói, de Dias Gomes. A obra foi publicada em forma de livro, na década de 1960. Chegou a ser montada em 1965, mas foi suspensa pouco antes de sua estréia. Seu enredo é uma crítica à criação de mitos históricos, tão frequientes no Brasil. No caso em questão, a falsa heroicidade de um cabo que serviu na Segunda Guerra Mundial pode ter suscitado a ira do regime militar da época. Posteriormente, em 1975, a peça recebe versão televisiva com o nome de A Fabulosa Estória de Roque Santeiro e Sua Fogosa Viúva, a que Era Sem Nunca Ter Sido, que também será censurada. Ela só chega a ir ao ar dez anos depois, levando o nome de Roque Santeiro, quando movimentos democráticos fortalecem-se no Brasil.

73 Sabendo do interesse de Osman Lins pelo cinema, deduz-se que a obra referida trata-se da comédia Viva Maria!. Dirigida por Luis Malle o filme traz Maria I e Maria II, personagens circenses interpretadas por Brigitte Bardot e Jeanne Moreau. Devido a um equívoco durante um tradicional número de canto, as personagens inventam o strip-tease e o circo fica famoso. Entretanto, em meio à trama, as Marias conhecem Hamilton, líder revolucionário socialista e as duas acabam levantando-se contra o ditador da região, a igreja e o capitalismo.

74 Arquivo do Instituto de Estudos Brasileiros USP - Fundo Osman Lins. Código do documento: OL/MAG/Cx2/P2/04 
quanto às gramáticas: "Breve relato de minha experiência com as gramáticas. Conclusão: os critérios são tendenciosos, cortejam a burguesia. ${ }^{75}, 76$

Como, apesar de tudo, Osman Lins escolheu formatar sua literatura e alcançar o seu público?

$1^{\circ}$ Deve escrever ou ganhar dinheiro?

Pois é quase certo que não alcançará as duas coisas.

(...)

O meu desprezo pelos valores materiais em geral facilitou-me a primeira ação. Pus, acima de tudo, o projeto de realizar uma tarefa de natureza espiritual.

(...)

Entre realizar obra aquém das minhas possibilidades e me fazer o melhor que me fosse possível, escolhi a última opção. ${ }^{77}$

Tal afirmação é confirmada em Guerra sem testemunhas:

O verdadeiro escritor não se resigna a dizer as coisas com prudência, assegurando a idéia; também considera um jôgo indigno e sem finalidade, acumular palavras, inebriando-se com elas. Ambiciona, isto sim, erguer as frases à altura do que tenta exprimir; atingir um ponto em que se interpenetrem o texto e seu sentido. (LINS: 1969: p. 200)

Assim, fiel aos seus ideais, o "verdadeiro escritor" seguirá suas convicções na elaboração da própria obra, enfrentando as dificuldades (que como demonstrado, não são poucas). Seu norte, mais que sucesso e reconhecimento, reside em seu leitor e nele, a possível permanência da obra literária. A busca pelo leitor, se estende até mesmo para dentro da sala de aula:

Que tem de fazer o escritor?

Jamais colaborar com o outro lado, com os inimigos da literatura.

(...)

Bater-se, por todos os meios possíveis, COMO FAÇO NESTE MOMENTO, POIS ESTOU AQUI LUTANDO POR UMA APROXIMAÇÃO COM POSSÍVEIS LEITORES. ${ }^{78}$

Eis, de maneira resumida, os temas e argumentos que constituem as aulas de Osman Lins sobre a natureza do escritor, seus problemas e dilemas. Convêm lembrar, porém, que a marca dessas aulas e o que torna o curso de Osman Lins diferente de outros cursos de Literatura Brasileira é que as reflexões teóricas que vimos descrevendo são permeadas pelo depoimento pessoal do próprio autor, de

75 Sobre o tema, ver também O livro didático - Primeiro tempo: 1965 e O livro didático - Segundo tempo: 1976. In: Do ideal e da glória (1977).

76 Arquivo do Instituto de Estudos Brasileiros USP - Fundo Osman Lins. Código do documento: OL/MAG/Cx2/P2/04

77 Arquivo do Instituto de Estudos Brasileiros USP - Fundo Osman Lins. Código do documento: OL/MAG/Cx2/P2/06

78 Arquivo do Instituto de Estudos Brasileiros USP - Fundo Osman Lins. Código do documento: OL/MAG/Cx2/P2/04 
modo que o caráter testemunhal constitui uma das peculiaridades da pedagogia osmaniana. Peculiaridades que, como demonstrado, apresentam-se também em seus ensaios, e em toda ação realizada por Osman Lins, que, sempre de forma coerente, refletiu e denunciou sobre o fazer literário, independente da sua atividade exercida.

\subsubsection{A estrutura da narrativa}

“Dispensável acrescentar que questiono permanentemente problemas como o do TEMPO, DO ESPAÇO, DO

FOCO NARRATIVO, etc.

Principalmente este último."

Osman Lins ${ }^{79}$

O segundo grande tema abordado em sala de aula por Osman Lins é a estrutura da narrativa. Se na primeira etapa, vê-se o paralelo entre as aulas e ensaios, com especial atenção a Guerra sem testemunhas, nesta segunda etapa, é sua obra ficcional que será utilizada para a exemplificação de análises literárias.

Seu curso, mesclado de teoria e práticas inovadoras, trará a conceituação técnica dos elementos que compõem a narrativa. Mas, da mesma forma como as aulas que tratavam da condição do escritor no Brasil, estas também contarão com a interferência das visões pessoais do escritor:

A nossa não é uma relação entre professor e aluno, mas entre escritor e leitores ou possíveis leitores. ${ }^{80}$

Dessa maneira, poderíamos dividir essas aulas em três grandes blocos. O primeiro deles é puramente técnico, apresentando conceitos de lingüística e Literatura de forma objetiva e ordenada, tal qual um livro didático. Nesse grupo temos as aulas intituladas "Os registros de fala" (que tratam de conceitos como enunciado, enunciação, referência e tipos de discurso, e é baseada no livro Estruturalismo e poética de Tzevetan Todorov); um esquema de aula, sem título, sobre a estrutura da narrativa (níveis de descrição da narrativa, funções, ações, baseado em Roland Barthes, Greimas e 
Propp); e "A narrativa" (trata resumidamente dos principais elementos da narrativa: tempo, espaço, personagem, fábula e foco narrativo).

O segundo bloco compreende planos de aula em que as idéias de Osman Lins como escritor e as análises de suas próprias obras passam a estar mescladas com a exposição teórica, e muitas vezes servem de espinha dorsal. No extremo de um menor grau de intervenção, temos um plano de aula sem título em que se discutem as características e a evolução do romance, como gênero. A maior parte das notas tem caráter objetivo, como, por exemplo, a definição de romance:

Narrativa imaginária mais ou menos extensa, escrita em prosa, onde um ou vários personagens vivem, no espaço e no tempo, aventuras de natureza material ou espiritual. ${ }^{81}$

Além disso, ao historiar a evolução do romance, cita, por exemplo, Cervantes, Fielding, Le Sage, Sthendal, Balzac etc. No entanto, a partir da metade da aula, suas observações passam gradativamente a valorizar o trabalho do romancista, num evidente eco da sua própria experiência, associado ao desejo de enfatizar sua visão da Literatura:

O romancista reflete. E na medida em que o seu espírito é capaz de alcançar ou abranger a realidade, traz-nos uma súmula, uma síntese dessa realidade. Quer que o leitor se alce a um grau superior. ${ }^{82}$

Osman Lins preocupa-se em diferenciar os falsos romancistas dos romancistas verdadeiros. Dos primeiros, diz que "seu processo é parasitário e seguro", enquanto que, sobre os segundos, afirma que "seu processo é pioneiro e aventuroso", e "que procura[m] formas novas para uma realidade nova" ${ }^{93}$. Por fim, roga ao leitor/ aluno que desconfie dos livros que lhe causem "fácil prazer", preferindo a eles aqueles mais difíceis de ler, pois por trás desses últimos esconde-se uma realização mais dramática do que a história narrada. Para esses livros e para os autores desses livros, Osman Lins pede especial atenção e não é difícil notar que é a ele mesmo que o pedido de atenção é dirigido, pois: 
Anos de vida, abdica de empregos, de tudo. Poderia escrever o livro em um ano. Leva 3, 4. Para dar o melhor, mesmo com muitas desvantagens, assume isto, permanece fiel a isto.

Tudo para que o seu trabalho seja o melhor possível, para que os leitores recebam, de suas mãos, o melhor. ${ }^{84}$

$\mathrm{Na}$ aula Etapas de uma exploração no país da narrativa: depoimento, a máscara do professor cai definitivamente:

Teorizar e testemunhar.

Esclarecer: não sou mais professor.

(...)

Isto, portanto, nada tem de aula. ${ }^{85}$

A aula é sobre foco narrativo, um dos principais aspectos formais que interessa a Osman Lins e, na demonstração da teoria, o professor-escritor passará a analisar a sua própria obra: Nove, novena.

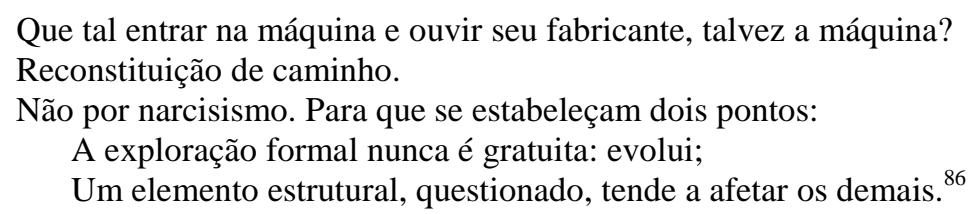

Serão abordados nessa aula os contos: "O pássaro transparente", "Um ponto no círculo", "Pentágono de Hahn", "Retábulo e Santa Joana Carolina", "Conto barroco ou unidade tripartida", "Noivado" e "Perdidos e achados". E, na aula que se segue a essa, intitulada Foco narrativo, fala de "Os confundidos", "Pastoral", além de retomar pontos de alguns dos contos já analisados anteriormente.

As notas são fragmentárias e apenas indicativas: registros mnemônicos para utilização posterior. Em geral, exigem um esforço de interpretação. Para "O pássaro transparente", Osman desenha um diagrama e anota ao lado dele: "Falar desse diagrama só quando me ocupar das estruturas significativas" ${ }^{\nexists 7}$. Quais são as estruturas significativas e o que o diagrama representa não é explicitado. Explícitas somente são as marcações sobre o foco narrativo: "Narrador impessoal e na $1^{\mathrm{a}}$ pessoa", 
juntamente com observações incompletas: "Por que transparente? Simples. Deixar de lado o tema" e “Um tatear". Depreendemos, no entanto, que o objetivo principal é falar sobre a estrutura e não sobre a temática do conto.

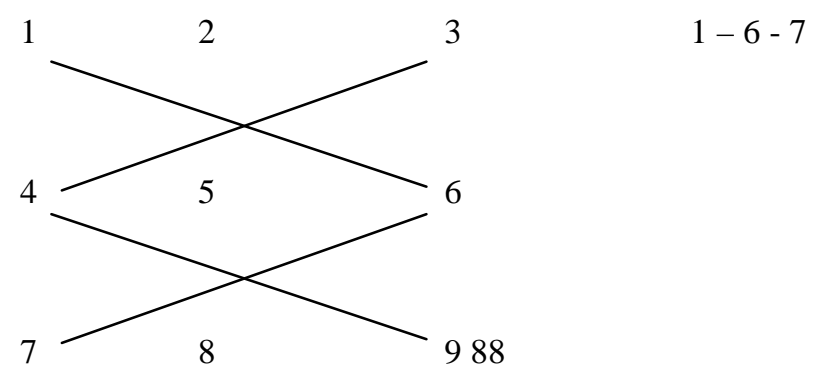

A crítica já identificou os nove quadros que compõem a estrutura do conto ${ }^{89}$ : os mesmos nove quadros que parecem estar representados no diagrama acima. Osman Lins sugere que haja uma relação entre quadros específicos, não só pelas linhas que ligam os quadros, mas também pela anotação aposta “1-6-7”.

Sobre "Um ponto no círculo", a discussão do tema é novamente posta em segundo plano, dando espaço para uma análise do foco narrativo (“Tema, rapidamente. Volta o FOCO”). As notas pretendem enfatizar a existência de dois focos narrativos:

$\square-$ Homem - recorda - Reconstitui um evento já ocorrido.
$\nabla$ - Mulher - Elabora um evento através do discurso. ${ }^{90}$

A conseqüência do contraste entre os dois focos é a instauração de "graus inteiramente diversos de ficcionalidade", isto é:

Aqui, parar um segundo e eliminar a idéia de um olho físico! Já estamos aí no campo da ficção e a realidade imediata já não nos governa !!! ${ }^{91}$

Osman Lins chama a atenção para o fato de que o discurso da mulher já não tem mais nenhuma pretensão mimética, e sustenta esse argumento indicando seu artifício para denunciá-lo dentro da 
narrativa: "acentuar na pg. $24^{92}$, início da fala de , o recurso para esbater o contraste: inicia no pretérito e passa $\mathrm{p} /$ o presente" ${ }^{93}$. O uso dos focos narrativos afeta o tempo, mas não no espaço, como também observa o autor: “mas não houve incursão no problema do espaço, que é o mesmo. ${ }^{94 "}$ Sandra Nitrini aponta tal característica:

\begin{abstract}
O modelo acronológico e adramático, extraído da organização global das narrativas, é inferido a partir da disposição espacial de seus módulos, cujas estruturas narrativas são abafadas, espremidas e minimizadas pela predominância do movimento da escitura, através de recursos técnicos específicos.

Esse modelo percorre Nove, novena de ponta a ponta, constituindo um modus faciendi obsessivo que enforma desde as narrativas voltadas para um único núcleo histórico, como "Os confundidos", "Noivado", "O pássaro transparente", "Pastoral" e "Um ponto no círculo", passando por "Conto barroco ou unidade tripartida" e "Retábulo de Santa Joana Carolina" até as narrativas que giram em torno de vários núcleos históricos, como é o caso de "Pentágono de Hahn" e "Perdidos e achados". No entanto, estas duas últimas radicalizam o processo de pulverização da história, sobretudo no âmbito da organização global do texto, graças às suas matérias compostas de vários núcleos históricos. (NITRINI: 1987, p. 73)
\end{abstract}

Aproveitando a citação acima e dialogando com as análises osmanianas, comprova-se que "O Pentágono de Hahn" representa um novo passo no processo de experimentação do escritor. Comparado ao "Pássaro transparente", temos novamente a visão de um menino e de um adulto, mas lá, segundo Osman Lins, o uso é simples. Aqui, temos:

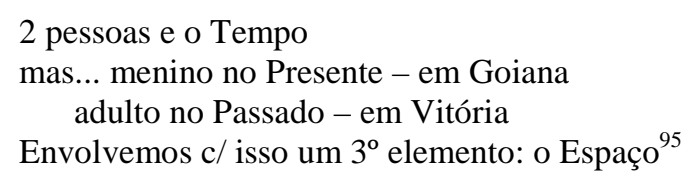

Essa situação reatualiza "novamente os problemas de Um Ponto no Círculo”, isto é, a questão do abandono de uma representação realista: a mistura no mesmo fluxo discursivo de dois tempos e dois espaços diferentes para um mesmo personagem.

De "Retábulo de Santa Joana Carolina", Osman Lins menciona somente um trecho no qual “Tempo e Espaço diversos [são] percebidos por um só personagem, não por 2", fenômeno que, segundo ele, "vai agravar-se" em "Conto barroco ou unidade tripartida". Sobre este último, as notas

92 O número da página refere-se à edição usada por Osman Lins, que desconhecemos. Na edição que usamos o trecho mencionado encontra-se provavelmente na página 21.

93 Arquivo do Instituto de Estudos Brasileiros USP - Fundo Osman Lins. Código do documento: OL/MAG/Cx2/P2/20

94 Arquivo do Instituto de Estudos Brasileiros USP - Fundo Osman Lins. Código do documento: OL/MAG/Cx2/P2/20

95 Arquivo do Instituto de Estudos Brasileiros USP - Fundo Osman Lins. Código do documento: OL/MAG/Cx2/P2/20 
revelam um desdobramento do personagem, que não ocuparia três cidades simultaneamente, mas opcionalmente, afetando a própria fábula e:

Acrescento: o leitor mesmo, que não sabe mais em que lugar situa os eventos: está em três cidades. 96

\section{Segundo Nitrini:}

(...) o encadeamento cronológico dessas funções pulveriza-se não apenas pela justaposição de quadros (...) mas também pelo recurso específico da introdução de módulos, cuja matéria central ultrapassa o núcleo diegético, mantendo com ele uma relação periférica do ponto de vista da ação principal. (...)

$\mathrm{O}$ esgarçamento dos fios narrativos e suas conseqüentes desdramatização concretiza-se graças à tripartição de alguns módulos e à inserção de quadros periféricos que ampliam o espaço textual entre os segmentos diegéticos centrais. Tais recursos específicos pulverizam a história, marcam o movimento da escritura, na grande sintagmática narrativa. (...)

A inserção de trechos insólitos e enigmáticos constitui, portanto, um dos recursos do fazer literário osmaniano para travar ou, pelo menos, retardar a transparência de segmentos narrativos lineares, que remetem a uma literatura mimética, enfatizando, dessa maneira, o movimento da escritura. (NITRINI: 1987, p. 98-103)

Ainda de acordo com as notas, esse personagem que flutua entre as cidades repercutirá em Mendonça de "Noivado". Nessa narrativa, a própria personagem, como entidade, será "ameaçada", “assediada pelas mutações no Espaço e no Tempo", sofrendo um impacto na sua construção, que será feita de "ferragens e sons". Quanto à relação do personagem no tempo e espaço, a crítica, posteriormente, detecta tal característica, e a aponta em vários momentos:

(...) "Noivado" compõem-se de discursos isolados e conjuntos da noiva, representada por ǒ e do noivo, representado por $\mathbf{I}$, de diálogos entre eles e os vários Mendonças e de trechos discursivos colocados entre parênteses, (...).(NITRINI: 1987, p.79)

O aparecimento de Mendonça em várias idades, além de representar um procedimento implicado, de modo direto, no processo de constituição da personagem, mexe com a instância temporal da narrativa: destemporaliza-a e, num movimento dialético, concentra seu processo de reificação, inserido obviamente numa temporalidade. (NITRINI: 1987, p.82)

Embora cada um encarne a visão própria das diversas etapas de sua história pessoal de reificação, a justaposição dos diferentes Mendonças, na mesma seqüência, quebra a linha evolutiva temporal, instaurando, ao longo da narrativa, verdadeiros segmentos atemporais ou, pelo menos, criando um clima insólito e inverossímel. ((NITRINI: 1987, p.84) 
No conto, a caracterização dos vários Mendonças, e de suas "ferragens e sons" é condensada na

fala da noiva:

\begin{abstract}
б̆ É o velho quem reponde. Os que o ladeiam olham-no de suas idades remotas. Ouço, no jovem, um ranger de dobradiças, de rolimãs sobre eixo não lubrificado. No outro, de trinta e nove anos, em algum impreciso recanto de seu corpo, uma roldana é acionada com insistência, pesos em forma de cubo vão e vêm no escuro. Diz o moço: "O mar está rugindo". A roldana interrompe os movimentos: "continua avançando na praia dos milagres". Interfiro: "onde, há um ano, havia residências, hoje só restam alicerces e alguns tijolos soltos!". Todos concordam: "É mesmo". Volta o silêncio e os três me contemplam, decerto sem ver-me, aflitos com o estorvo de suas almas de serragem, de colheres dobradas, de facas cegas, comportas e alçapões. Uma noite foram dez os que vieram; ocuparam o sofá, as seis cadeiras, o banco do piano, todos irados, numa agitada conversa a respeito de grades e portões. Infelizmente, são em geral esses três que me visitam. O de sessenta anos faz-me lembrar um zoológico onde todos os bichos estivessem mortos e mesmo assim visitados. Mas uma noite eu o vi aos dezessete anos. Encheu a sala de sons, contou a história da primeira mulher que se deitou com ele, ouviu-me. Há mais de quatro anos aguardo seu retorno. Desejaria revê-lo, ardoroso e sensível, talvez um pouco perverso, com seu rumor de címbalos e guizos. (LINS: 1994, p. 153-154)
\end{abstract}

As notas dessa aula acabam com "Perdidos e achados". Para Osman Lins, essa narrativa, posta no fim do livro, é, de certo modo, a culminância e a "súmula das explorações feitas". Neste momento da aula, ele pede que os alunos recordem as observações iniciais da exposição que falam da evolução da exploração formal e da influência de um elemento estrutural sobre os demais quando questionado:

Reconstituição de caminho.

Não por narcisismo. Para que restabeleçam 2 pontos:

$\rightarrow$ a exploração formal nunca é gratuita: evolui;

$\rightarrow$ um elemento estrutural questionado, tende a afetar os demais.97

Também o título e o tema dessa narrativa, "Perdidos e achados", ganham importância, pois "ele nos remete a própria aventura do livro: nele muito perdi e muito achei”. ${ }^{98}$

A aula intitulada Foco narrativo se inicia com algumas conceituações teóricas sobre o tema. O argumento principal é de que antigamente o uso de determinado foco narrativo estava subordinado à busca da veracidade do texto, enquanto que, modernamente, o foco narrativo livra-se dessa determinação e não se esquiva em mostrar-se artifício. Em seguida, são retomados rapidamente alguns pontos das narrativas analisadas na aula anterior: "O pássaro transparente", "Um ponto no círculo" e "Pentágono de Hahn". Dessa revisão, Osman Lins quer que fiquem claros três pontos: 
a) o abandono do narrador impessoal (só em O Pássaro) - Tudo na $1^{\mathrm{a}}$ pessoa.

b) pg. 67 - c/ isto, a concepção do F.N. proclama a sua liberdade. Não está preso à realidade imediata.

c) o caráter do discurso: literário. - Não há mimetismo. (Ver, p. ex., 66/7)

Que concluir de tudo isto? Que esse EU reveste-se de um valor novo. Pronome em lugar do nome? Aqui não fica no lugar de ninguém. Simples recurso expressivo p/ sustentar o discurso. 99

De "Os confundidos", narrativa não analisada na aula anterior, Osman Lins diz que ela "leva mais longe a pesquisa do F.N. - elimina a $3^{\text {a }}$ pessoa, de modo que a narrativa é contemplada de lugar nenhum". Sobre "Pastoral”, uma observação similar: "Quem narra? Um menino rústico. Como nos fala?" e "Mais: descreve-se morto." Apresentados todos os contos de Nove, novena, e suas características de foco narrativo, Osman Lins retoma "Retábulo de Santa Joana Carolina”, por conter “características muito especiais":

DESENHAR. Retábulo, não insistindo na estrutura. - Explicar como foi concebido aí o F.N. Tudo em torno da figura central; muitas vezes; o contemplador imaginário.

Nesta mesma narrativa, introduz-se a voz coletiva. Mostrar. - O recurso reaparece em Perdidos e Achados, súmula do livro, como já visto. ${ }^{100}$ 


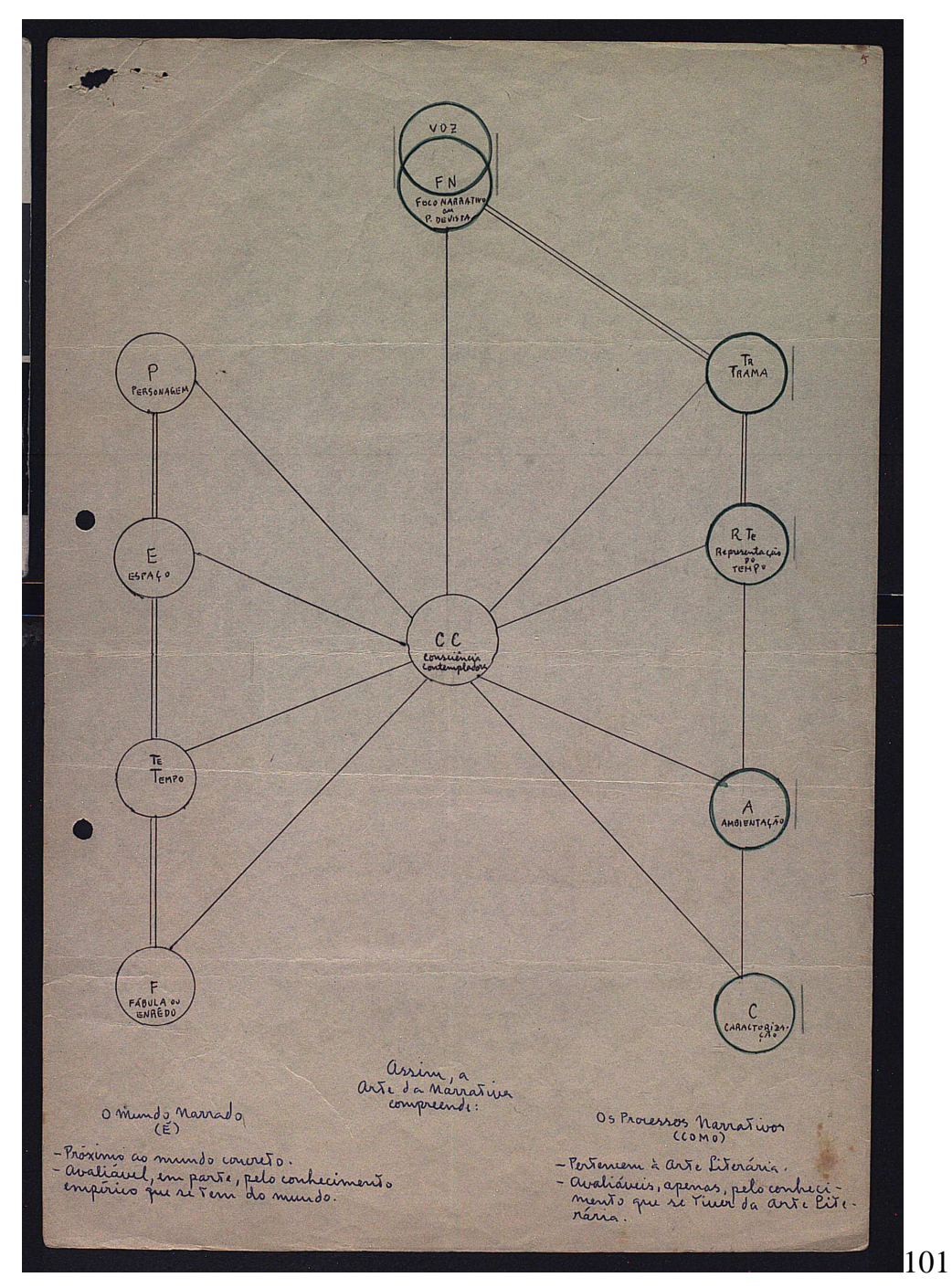

As duas aulas que acabamos de descrever mostram o papel central que o foco narrativo tinha para a construção das narrativas osmanianas, como ele mesmo não cansa de salientar:

No meu caso especial, [o foco narrativo] não pode ser ignorado, se se quer estudar os meus processos. ${ }^{102}$

E, a partir das análises que Osman Lins faz de Nove, novena, vemos como, progressivamente, na seqüência das narrativas, as experiências de questionamento das estruturas narrativas são intensificadas, seja pelo tipo de experimentação realizada, seja pela quantidade de elementos estruturais desafiados. 
A noção de aula é quase que totalmente obscurecida no material sem título que se inicia com a seguinte frase: "Objetivo: assinalar o percurso, ou talvez a evolução, na minha ficção de alguns elementos constitucionais" ${ }^{103}$. Novamente, Osman Lins pretende insistir como fora de sua "configuração habitual" um elemento narrativo tende a afetar os demais. Sete dos contos de Nove, novena recebem breves observações, mais ou menos nos mesmos moldes das duas aulas anteriores. Acentua em "O pássaro transparente" a coincidência entre os focos "de fora e de dentro"; em "Um ponto no círculo", o tempo duplo e o espaço único; em "Pentágono de Hahn", o templo duplo e a "espacialidade projetada no cilindro", afetando "a integridade do mundo representado"; em "Os confundidos", a duplicação do eu, o comprometimento da relação espacial, a "subversão da linguagem" e o "deslocamento do centro do leitor; em "Retábulo de Santa Joana Carolina", os ornatos; em "Conto barroco ou unidade tripartida", a "dupla visão", a "dupla espacialidade" e o "personagem afetado na sua integridade; em "Pastoral" o "eu", “o final” e "o personagem de cipó". Todas essas notas, ainda que ligeiramente diferentes das notas das aulas anteriores, repetem, quase nos mesmos termos, a análise já realizada.

Mas, o objetivo mais saliente da exposição torna-se

tentar recuperar - o que só é possível parcialmente - a construção de uma narrativa específica, demonstrando o reflexo, nela, das explorações que a antecederam; testemunhar sobre o aproveitamento e a transformação dos diversos materiais incorporados à mesma narrativa. 104

A narrativa específica escolhida é "Noivado". As notas de explicação da composição desse conto provêm de duas fontes: a aula que vimos descrevendo, datilografada com correções ou adições manuscritas e três páginas manuscritas que tratam somente dessa narrativa e que, apesar de estruturada de maneira um pouco diferente e de conter algumas observações adicionais, basicamente aborda as mesmas questões. Por essa razão consideraremos essas duas fontes como se fossem uma só, na hipótese de que a versão manuscrita tenha servido de base para a versão datilografada final. Além disso, vale ressaltar que, no espaço dessa dissertação, não vamos fazer uma nova análise desse conto, 
mas apenas descrever e analisar como o próprio Osman Lins testemunha sua criação. De modo que seria possível reunir esse conjunto de aulas sob o título "Discurso do Processo Criativo de Osman Lins".

Comecemos com o que Osman Lins indica como sendo a origem da idéia do conto:

Conheci casos.

A "história" se impunha: aposentou-se e é noivo;

Mas não vai casar e sim romper, com o

Que se define pela esterilidade. ${ }^{105}$

Da idéia inicial, derivam-se idéias complementares:

Funcionário: desumanização; mecanização.

A desumanização do trabalho provocando falta de adesão ao mesmo, de modo que o homem fixa-se na idéia de aposentadoria.

Esse clima afetando as relações humanas.

Projetar isto na vida particular, que recebe o contágio da aridez e da falta de futuro da vida funcional.

Daí o noivado eterno. ${ }^{106}$

Aí está, segundo o próprio Osman Lins, o tema da história: um verdadeiro resumo do seu núcleo. No que concerne a estrutura geral da narrativa, o autor também apresenta seu ponto de partida:

ORGANIZAÇÃO - Desafio básico: o anti-conflito dramático. ${ }^{107}$

Ambos querem terminar o noivado. ${ }^{108}$

E as configurações dos personagens também tem motivação especial:

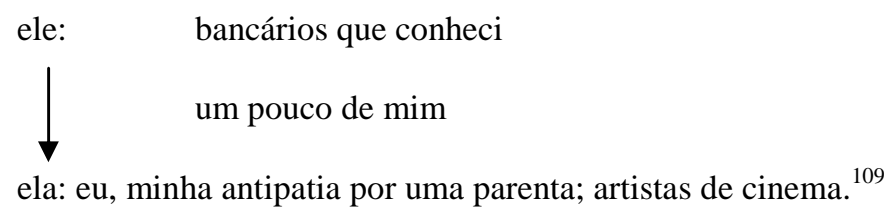

105 Arquivo do Instituto de Estudos Brasileiros USP - Fundo Osman Lins. Código do documento: OL/MAG/Cx2/P2/22

106 Arquivo do Instituto de Estudos Brasileiros USP - Fundo Osman Lins. Código do documento: OL/MAG/Cx2/P2/23

107 Arquivo do Instituto de Estudos Brasileiros USP - Fundo Osman Lins. Código do documento: OL/MAG/Cx2/P2/22

108 Arquivo do Instituto de Estudos Brasileiros USP - Fundo Osman Lins. Código do documento: OL/MAG/Cx2/P2/23

109 Arquivo do Instituto de Estudos Brasileiros USP - Fundo Osman Lins. Código do documento: OL/MAG/Cx2/P2/23 
Definido o tema, estabelecida a estrutura geral que rege a narrativa e esboçados preliminarmente os personagens, Osman Lins detalha a fase que chama de "convocação de material"110. Conforme o escritor, essa fase demanda "várias semanas de preparativos". O trabalho consiste no acúmulo dos motivos que irão compor a história:

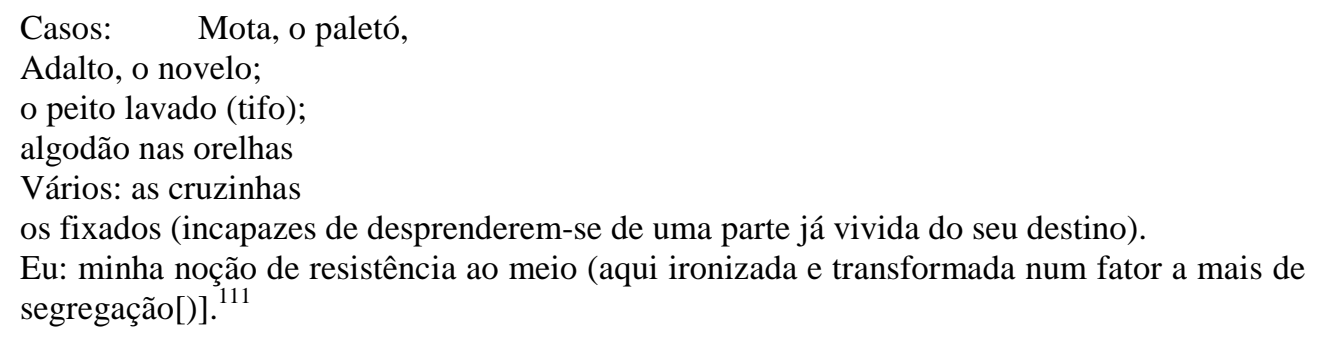

Vemos como Osman Lins utiliza material retirado da vida real, para construir a narrativa, incluindo a sua própria experiência. Por fim, dois motivos adicionais, retirados provavelmente de seu estoque:

$$
\begin{array}{ll}
\text { Outros motivos: } & \text { o pássaro (6 ou } 7 \text { anos antes). Surgiria depois. } \\
& \text { Os fogos de artifício sobre o corpo nu (imaginário). }{ }^{112}
\end{array}
$$

Inicia, então, o planejamento dos elementos estruturais do conto. Primeiro, o foco narrativo: “mais de uma voz”, "sendo que a visão deles não é natural”; multiplicação do homem em três, em 60, 39 e 28 anos". Mas Osman Lins adverte: “não é divisão de "personalidade”". A conseqüência dessa multiplicação sente-se na configuração do espaço, do tempo e da personagem. Sobre o tempo: "vários Mendonças, possibilitando, sem retrospecto, conhecendo sua transformação em [ilegível] da burocracia". Sobre o personagem:

Nada de introspecção (sentiu etc.) Ele vai ser composto de ferragens, percebidos através de SONS. ${ }^{113}$ 
Osman Lins confirma que existe uma oposição entre os sons pesados do adulto e os sons melodiosos do adolescente, em que a expressão de suas obsessões são expressas na sua fala na forma de um discurso que se assemelha a um relatório.

O autor destaca outro motivo, o mais importante e elaborado, de função simbólica polivalente, o qual ele também chama de ornato: os insetos. Esse motivo, de fato, aparece em quantidade numerosa na narrativa, exercendo diferentes papéis. Osman Lins chega a indicar as páginas em que ele aparece e revelar seus significados:

\begin{tabular}{|l|l|}
\hline Número da página & \\
\hline 185 & ironiza o repouso de Mendonça \\
\hline 188 & "esvaziamento da substância humana" \\
\hline 191 & ordenação e segurança \\
\hline 193 & $\begin{array}{l}\text { liga-se ao motivo dos vidros quebrados: "associa-se claramente o inseto aos } \\
\text { buratas" }\end{array}$ \\
\hline 194 & motivo da sobrevivência, da reflexão, em meio à esterilidade da burocracia \\
\hline 195 & desmoralização dos fundamentos científicos \\
\hline $195 / 6$ & "imagem negativa da burocracia" \\
\hline $198 / 9$ & "força de sobrevivência da literatura" e "profético: o gigantismo da burocracia \\
\hline 199 & a invasão do mundo pelos burocratas \\
\hline 199 & "evoca força da vida e da reprodução" \\
\hline
\end{tabular}

Para finalizar, Osman Lins explica o final da narrativa: "uma espécie de apelo aos sons cristalinos da infância" e a presença da mangueira, última palavra da narrativa, "árvore cuja conotação de descompromisso e de ligação com a infância é bem conhecido de quem foi menino no Nordeste."

Realmente, o último parágrafo do conto retrata tudo isso: 
(...)Fecho os olhos e recordo os alegres rumores cuja volta esperei em vão ao longo destes anos, sinetas de colégio, guizos, maracás, sons de brinquedos de corda, balanço de criança rangendo compassadamente em sombreados galhos de mangueira. (LINS: 1994, p. 169)

O terceiro bloco reconhece-se pela referida prática inovadora114 que questionará a tradição teórica até aqui usada em suas aulas. Nesta etapa, o diálogo entre aulas e obra estende-se a Do ideal e da glória: problemas inculturais brasileiros. Apesar de publicado posteriormente à carreira de professor, o livro traz ensaios dedicados à experiência do escritor na sala de aula, e idéias que foram amadurecidas durante o período em que Osman Lins exerceu o magistério. Assim, aos planos de aula, esses textos servem como complemento. Pela escolha das análises privilegiarem o material presente nos documentos do Fundo Osman Lins, os ensaios publicados não serão aqui examinados de forma detida, usados apenas quando forem necessários ao diálogo com a documentação do escritor.

\subsection{As aulas de Teatro}

"O fato de que o texto teatral é escrito para a cena faz do teatro uma arte de situações"

O momento do curso dedicado à Arte Dramática, mais do que profundidade, traz a intenção do escritor em se aproximar a uma espécie de instrumentação para as atividades didáticas propostas por Osman Lins. Dentre o material presente no arquivo, há um conjunto de cerca de 44 documentos referentes à teoria teatral, que inicialmente foram considerados como planos de aulas ministrados aos alunos de Marília. Entretanto, mediante uma leitura atenta, dois aspectos apresentaram-se como argumento de dúvida quanto à utilização desse material pelo professor Osman Lins: o primeiro diz respeito a datas que, em dois documentos, indicam o ano de $1959^{116}$, ou seja, cerca de onze anos de 
diferença entre tais registros e o início de Osman Lins como docente na Universidade; o outro aspecto aponta para a densidade dos conteúdos ${ }^{117}$. Os temas das possíveis aulas seriam:

1. "O texto literário"

2. "As origens da Arte. Teoria do Jogo"

3. "Estética de baixo"

4. "Concepção Kantiana da Arte"

5. "O Cômico"

6. "A Arte e a moral"

7. "O Sublime"

8. "O Mal e o Feio na obra de arte"

9. "O Drama"

10. "Ofício, técnica e forma"

11. "As Fontes Teatrais"

12. "O Texto Teatral"

13. "Realismo do texto teatral"

14. "Relação entre o texto e o espetáculo"

15. "O Nascimento da obra"

16. "As regras teatrais"

17. "O autor. Visão do mundo"

18. "O princípio da predominância da ação"

19. "O reconhecimento"

20. "O desenvolvimento"

21. "O clímax"

22. "A parte final"

23. "A peripécia"

24. "Planificação do drama"

117 Vale ressaltar que dentre a documentação mantiveram-se duas etiquetas feitas por Julieta de Godoy Ladeira, com a indicação: 1) Aula de OL (teatro) e 2) Arte teatral / Aulas dadas por OL. A separação inicial não gratuita reforça nossa hipótese sobre as diferenças do material. 
25. "A linguagem dramática e a cômica"

26. "Planificação da comédia"

27. "O personagem cômico"

28. "A tragédia"

29. "O dramático"

30. "O cômico"

31. "Textos de privação"

32. "Textos de síntese"

33. "A tragédia grega"

34. "A Tragédia Elizabetana"

35. "O primeiro ato"

36. "Planificação da ação tragédia"

37. "O personagem trágico"

38. "A linguagem trágica"

39. "Planificação das sínteses e dos movimentos da privação"

40. "O personagem dos textos de privação"

41. "A linguagem das peças de síntese e de privação"

42. "O personagem dramático"

A partir dos títulos, reconhece-se uma minúcia desnecessária para um curso de Letras. Porém, tanto a indicação das datas quanto a temática aprofundada nos remetem ao período de formação de Osman Lins. Como dito no Capítulo 1 do presente estudo, Osman Lins realizou o curso de dramaturgia na Escola de Belas Artes da Universidade do Recife, finalizando-o em 1960, um ano após a indicação cronológica presente nesta documentação. Voltando ao título e aos conteúdos, no decorrer das possíveis aulas, conceitos de filosofia permeiam uma densa referência a autores gregos representados por Aristóteles, Platão, Heráclito, Homero, Sófocles e Parmênides, como não poderiam deixar de ter; filósofos como Hegel, Kant, Bérgson, Hobbes, Nietzche, Schopenhauer, São Tomaz, Santo Agostinho 
entre outros e escritores como, Shakespeare, Brech, Henrik Ibsen, Sthendhal, Dostoievski. Dentre os gregos, percebe-se a predominância de autores e teóricos da arte dramática. Sobre os filósofos, recai a primazia pela estética e finalmente, entre os escritores, com exceção de Sthendhal e Dostoievski, os demais são referências fundamentais a um estudioso teatral.

Osman Lins deixa claro, em seus ensaios, a preocupação com as novas técnicas de ensino, pautadas no estruturalismo, que, segundo o autor, traz receitas de análise literária, na tentativa de suprir o déficit de leitura dos alunos, alimentando a "gigantesca máquina de enganar que é o atual ensino brasileiro" ${ }^{118}$ :

os métodos de abordagem a que nos referimos, apesar de complexos, são mesmo assim claramente articulados, rígidos, seguem determinados cânones, obedecem a fórmulas bem definidas, e, por tudo isso, podem ser ensinados, embora um tanto superficialmente, mas, ao mesmo tempo, com uma certa eficiência, a alunos com escassa ou nenhuma experiência de leitura. (LINS: 1977, p. 86)

Ao leitor menos atento, soa a crítica ao estruturalismo. Entretanto, as posições rígidas de Osman Lins, demonstradas até aqui, não deixam dúvida sobre a crítica ao uso indevido da metodologia estruturalista, adotada (muitas vezes por colegas despreparados) no ensino de Literatura:

(...) Apesar das insuficiências dos alunos, altamente imaturos e despreparados, continuam os professores a organizar e ministrar seus cursos de graduação como se estivessem diante de si alunos ideais, ou ao menos, com alguma leitura, quando não são raros os que chegam à faculdade sem nunca terem lido uma obra literária sequer (...). A esse auditório, evidentemente sem condições para a tarefa a que se candidata (...), costuma o professor ministrar uma dieta maciça de escritores teóricos, que, contrapostos à escassa leitura dos alunos, soam de maneira estranha. (LINS: 1977, p. 82)

Tendo isso em mãos, sabe-se que Osman Lins não cairia no mesmo erro, ao propor uma dieta recheada de autores clássicos e filósofos. Diante disso, o estilo apresentado nas aulas, torna-se um possível diferenciador no que foi usado por Osman Lins como professor e o que lhe foi ministrado enquanto aluno do curso de dramaturgia, em Recife. O diferencial é a forma de registro dos documentos, sendo parte deles apresentados com títulos temáticos, em tópicos numerados, datilografado e uma pequena parcela composta com anotações manuscritas, algumas vezes com 
correções sobrepostas sobre os registros datilografados, mas longe de uma estruturação limpa e clara como a maioria dos demais documentos.

Muito mais intensas, as anotações trazem referências a alguns dos pensadores e autores da arte dramática anteriormente apontados, mas escritas de forma inquieta, em registros mnemônicos e quadros estilizados.

Dentre elas destaca-se um texto corrido, inicialmente datilografado, mas com muitas correções manuscritas, que analisa a adaptação da peça $O$ balcão de Jean Genet. As reflexões de Osman Lins criticam veementemente a produção do espetáculo que na época, com a direção de Victor Garcia, consumiu cerca de "duzentos mil cruzeiros", abrindo mote para a reflexão sobre as produções culturais e às condições sociais da realidade onde esta se insere. O levantamento realizado sobre o período em que a produção esteve em cartaz, aponta o ano de 1969, um ano antes de Osman Lins assumir a cátedra de Literatura Brasileira, data muito mais próxima para servir de ilustração às aulas, dos que os demais documentos que marcam quase onze anos de diferença.

Assim como as aulas de teoria literária não apresentam um plano, o mesmo ocorre com as possíveis aulas de arte dramática. Há uma possível exceção de um esboço, que traz o esquema de nove tópicos. São eles:

1. Concepção kantiana da arte. - Categorias do estético: Aristóteles.

2. Concepção hegeliana da arte. - Categorias do estético: [Lalo].

3. O trágico. - A arte e a moral.

4. O cômico. - A gratuidade da arte.

5. Teoria bersoniana do cômico. - As origens da arte: teoria do jogo.

6. Concepção kantiana do sublime. - forma, Técnica e ofício na obra de arte.

7. Concepção hegeliana do sublime. - Hierarquia e classificação das artes.

8. O mau e o feio na arte. - A estética de baixo.

9.

119

O nono não é completado e os demais dialogam diretamente com os 42 temas já elencados anteriormente. Enquanto há cerca de 30 planos de aula sobre teoria literária, haveria motivo diante de todos os argumentos do próprio Osman Lins de ater-se por tanto tempo à arte dramática? Chegou-se à conclusão que não e a hipótese é que talvez os planos tenham sido sim usados pelo professor, mas 
como material fonte para posterior adaptação aos alunos, tendo como apoio declaração colhida no ensaio Uma experiência didática:

\begin{abstract}
Alguém desejará saber se as encenações dos autos (Na Festa de Natal e Na Vila de Vitória) foram satisfatórias do ponto de vista teatral. Não. Foram, ao contrário, cheias de defeitos, não obstante a generosa colaboração de amadores de teatro da cidade. Temos, porém, aqui, um ponto de importância a discutir. Acho que, em experiências dessa ordem, não só é dispensável que a encenação seja perfeita, como é desejável que não seja. Se a encenação é perfeita ou busca a perfeição, há um desvirtuamento. Estaremos, aí; ensinando Arte Dramática e não Literatura Brasileira. (LINS: 1977, p. 73)
\end{abstract}

Tal reflexão nos indica mais uma vez para o caminho que aponta que o material descrito não seria adequado para o uso direto em aula, além de mais uma vez reforçar a verdadeira preocupação de Osman Lins com o curso de Literatura Brasileira e o uso da dramaturgia e de disciplinas como História da Arte como ferramentas no processo de formação de seus alunos de Letras. 


\section{Capítulo 3}

\section{O curso de História da Arte}

"Mas a relação da linguagem com a pintura é uma relação infinita."

(FOUCAULT: 1999, p.12)

\subsection{Literatura e outras artes na Teoria Literária e na obra osmaniana}

Afastemo-nos brevemente da prática docente de Osman Lins e façamos um recuo, voltando-nos para a já amplamente discutida relação entre a Literatura e as outras artes. Essa proposta de relação não é nova: existe grande quantidade de trabalhos que apontam para semelhanças e diferenças entre as várias formas de expressões artísticas - a arquitetura, a escultura, a Literatura, a pintura, a música, a fotografia, o cinema e outras manifestações que começam a surgir diante das novas tecnologias. Com o passar do tempo, ora as semelhanças, ora as diferenças são mais acentuadas. Na Época Clássica, inicialmente com Horácio e sua Arte Poética, surge a chamada teoria das Artes Irmãs, que encontra na frase latina Ut Pictura Poiesis a súmula para defender a proximidade entre poesia e pintura, em que se nomeia a pintura de "poesia muda" e a poesia de "pintura falada".

No final do século VI, o papa Gregório Magno cunha aquela que se tornaria a célebre frase do período: "A pintura pode fazer pelos analfabetos o que a escrita faz pelos que sabem ler" ${ }^{120}$, quando defende importância das pinturas nas paredes das igrejas, as quais retratavam trechos das escrituras bíblicas. Marca-se, assim, outro frutífero casamento para o estudo comparado das expressões artísticas, protagonizado pela defesa da fé e pela busca da catequização e conversão do povo, por meio das imagens, sejam elas afrescos, mosaicos, vitrais ou esculturas. 
Tal paralelo encontra ressonâncias profundas até o Renascimento, apesar de conceitualmente o movimento diferenciar-se em seu cerne dos anteriores, em sua tentativa de solidificar a importância do homem, independente de Deus. Obras importantes da época ampliam os estudos comparativos, por exemplo, o tratado De pictura de Alberti, no qual o autor

adota as noções da retórica para a composição do quadro bem articulado, composito, sublinhando o papel dos elementos singulares da imagem numa composição hierárquica análoga à subdivisão clássica da frase em sentença, oração e palavra. (...) Alberti enfatiza que a totalidade do quadro deveria submeter-se à centralidade da narrativa - a 'história' como princípio de organização intrínseca do perspectivismo. (SCHØLLHAMMER: 2007, p. 13)

Dessa forma, vemos a aproximação entre a escrita e a imagem tomarem frente na discussão entre as semelhanças das expressões artísticas. Ainda no Renascimento, contamos com os apontamentos de Leonardo da Vinci, reunidos no que se chamou de Tratado de Pintura, em que as comparações entre o escritor e o pintor abrem uma polêmica que se estenderá por todo o livro, alcançando o questionamento dicotômico sobre o papel do músico e do escultor. É interessante perceber que, em nenhum dos casos até aqui apontados, a abordagem é neutra ou ingênua. No último caso, Leonardo defende a superioridade da pintura, sem o menor constrangimento.

Em 1766, Gothhold Efraim Lessing marcará definitivamente uma linha divisória entre a palavra e o desenho, com seu livro Laocoonte. Usando as palavras de Schøllhammer, "o autor alemão observa que a representação pictórica pertence ao espaço, sendo portanto essencialmente estática e não progressiva, ao passo que a poesia pertence ao tempo, sendo portanto dinâmica e progressiva" (SCHØLLHAMMER: 2007, p. 13).

Entretanto, apesar do questionador estudo de Lessing, a tradição das Artes Irmãs ressurgirá com força na modernidade, em estudos como o de Mário Praz, traduzido no Brasil como Literatura e Artes Visuais, o qual, segundo especialistas como Thomas Mitchell121, chamará de "a cilada

121 Willian J. Thomas Mitchell é professor da Universidade de Chicago. Editor da revista Critical Inquiry, em 1980 editou um número especial com o nome The Languages of Images. É autor de vários livros sobre o assunto, dentre eles What do Pictures Want? the Lives and Loves of Images e Picture Theory: Essays on Verbal and Visual Representation, no qual, segundo Schøllhammer, "expõe a idéia de que a imagem hoje emerge como paradigma dentro das ciências humanas, da mesma maneira como teria ocorrido nos anos 1960 com a linguagem, caracterizando a chamada virada lingüística. Ou seja, a imagem não constituiria apenas um tópico privilegiado de interesse, mas uma característica cultural predominante, percebida, por exemplo, nas teorias de Guy Debord (1967) sobre A sociedade do espetáculo e de Foucault (1983) sobre a sociedade da vigilância panóptica. (...) A reflexão de Mitchell sobre o paradigma contemporâneo da imagem encontra seu fundamento no trabalho seminal de Foucault (1987), As palavras e as coisas. A relação entre o enunciável e o 
comparativista”. Mais do que um simples levantamento descritivo do que está sendo a nós apresentado, é necessário nos questionarmos sobre o que nos está sendo apresentado e o por quê daquilo nos estar sendo apresentado. Ainda usando as palavras de Schøllhammer (2007, p. 16),

o que define uma época histórica é o que pode ser dito e o que pode ser visto; em cada época, todo dizível é dito assim como todo o visível é visto, ainda que não devamos confundir os dois níveis. (...) Devemos portanto entender o visível não como uma visibilidade óptica, mas como uma visualidade, um procedimento representativo que não é necessariamente objeto de uma observação consciente: na verdade, é anterior a ela, apresenta-se como uma forma de luminosidade, uma luz como forma, imanente nos objetos.

No que se refere à obra literária, a fortuna crítica de Osman Lins tem chamado a atenção para seu forte apelo visual e estabelecido suas relações com a pintura e a arquitetura. Dentre os estudos anteriores que apresentam traços comparativos entre as várias expressões artísticas presentes na escrita osmaniana, destacamos o ensaio de Ermelinda Ferreira, que realiza uma aproximação da Literatura com a tapeçaria ${ }^{122}$.

Posteriormente, de forma mais alongada, Ermelinda Ferreira compara a obra osmaniana às pinturas de Arcimboldo, Dali, Magritte e outros, no livro Cabeças compostas: a personagem feminina na narrativa de Osman Lins. Desdobramento de sua dissertação de mestrado, Ermelinda propõe traçar as relações intersemióticas da obra de Osman Lins com técnicas específicas utilizadas na Literatura, pintura e na música medievais e barrocas. Apesar da autora não acrescentar em seu estudo a possibilidade de aproximação entre a obra de Osman Lins e as gravuras de M. C. Escher ${ }^{123}$, aqui, sem grandes pretensões, sugerimos o que acreditamos ser um estudo pertinente entre a segunda fase da produção osmaniana e a produção do gravurista ${ }^{124}$.

\footnotetext{
visível, tal como é examinada nessa obra, consolidou uma definição de época que permitia compreender a modernidade em termos representativos. (SCHØLLHAMMER: 2007, p. 15)

122 FERREIRA, Ermelinda. A dama e o unicórnio: exercício de imaginação. In: Almeida, Hugo (org). O sopro na argila. São Paulo: Nankin Editorial, 2004.

123 Maurits Cornelis Escher (1898-1972), morre um ano antes da publicação do romance Avalovara. Apesar da proximidade e de praticamente pertencerem à uma mesma geração, não se encontrou referência direta sobre o contato de Osman Lins com as gravuras de Escher. Entretanto, a biografia de ambos apresenta pontos de contato que valem a pena serem apresentados. O gravurista foi autor de cerca de 448 gravuras, interessava-se por tapeçarias, e pelo que seus críticos chamam de divisão do espaço, que gerariam seus conhecidos desenhos sobre os "espaços impossíveis". Assim como Osman Lins que modificou sua visão a partir de sua experiência na Europa, será na Itália que Escher alimentará a criação de novas gravuras e dali sairão esboços que ele utilizará por toda a vida. Não cabe ao presente estudo o desenvolvimento de tal temática, que necessitaria atento levantamento, entretanto, fica o registro que será desenvolvido em próximo e pertinente momento. Dados retirados do site oficial do artista: http://www.mcescher.com/, acessado em 17 de abril de 2011 , às $14 \mathrm{~h} 28$

124 A presente comparação não é originária da pesquisadora. Tal proposta remete às conversas realizadas em encontros nos quais, um grupo de alunos de graduação, durante os anos de 2001 a 2004, sob a coordenação da professora Sandra Nitrini, encontrava-se regularmente para trabalhar com a obra osmaniana. Deste trabalho surgiu primeiramente a publicação Marinheiros de Primeira Leitura
} 
Voltando à fortuna crítica de Osman Lins, Luiz Ernani Fritoli, na dissertação intitulada Do ideal e da obra: visualidade e conformação do espaço literário em "Retábulo de Santa Joana Carolina”, de Osman Lins, também apresenta um estudo analítico-interpretativo do espaço literário e suas relações com as artes visuais, a partir da narrativa "Retábulo de Santa Joana Carolina", que compõe o livro Nove, novena. Em importante diálogo com a técnica da narração e a écfrasis, o trabalho de Ernani mostra como a plasticidade da linguagem imbrica-se por meio do espaço onde ocorre a narrativa. Dessa maneira, o local de composição descrito, somado ao foco narrativo, compõe a chamada plasticidade da Literatura. Ernani aponta, em "Retábulo de Santa Joana Carolina", a plasticidade aliada às técnicas teatrais. Dessa maneira, em Osman Lins, podemos concluir que quadros e cenas dialogam e assemelham-se de forma particular. Usando as palavras de Fritoli:

A representação literária de uma outra manifestação artística - principalmente a pintura não é novidade inventada por Osman Lins. Esse processo de transposição, a écfrasis, tem uma longa tradição na literatura ocidental. Mas Lins é um perito nesse processo, e no caso do "Retábulo de Santa Joana Carolina" vai além da tradição: o texto como escultura, pintura ou entalhe, as cenas organizadas no modo típico de outro gênero artístico: o teatro. (FRITOLI, 2004, p.121)

O livro Marinheiro de primeira viagem será analisado atentamente a partir de uma série de ensaios $^{125}$ produzidos por Sandra Nitrini, dedicados à comparação entre Literatura e pintura. Ela resgata um livro muitas vezes diminuído pela crítica, mas que tem se mostrado como parte fundamental para a composição da fortuna crítica da obra osmaniana ${ }^{126}$. Dessa forma, Sandra Nitrini inclui Marinheiro, em $\mathbf{O}$ tempo na arte, a arte no tempo (uma leitura de Marinheiro de primeira

\footnotetext{
pela editora Hucitec, em 2004. Dentre os cinco ensaístas que participaram da publicação, três delas deram continuidade aos seus estudos: Fabíola Moura, com a dissertação Serpente em espiral (o movimento do erotismo em Avalovara), dissertação de mestrado DTLLCFFLCH, 2009; Rosângela Felício dos Santos, com a dissertação Osman Lins e o Suplemento Literário d'O Estado de São Paulo (1956-1961): cotejos com sua obra ficcional e Elisabete Marin Ribas, com o presente estudo. Dessa maneira, atribuo aos colegas do inicial grupo, em especial a Rodrigo Leite Gouvêa e Rosângela Felício dos Santos, a indicação do possível diálogo entre a literatura de Osman Lins e as gravuras de M. C. Escher.

125 Dentre eles, Marinheiro de primeira viagem, in: Transfigurações: ensaios sobre a obra de Osman Lins. São Paulo: Hucitec, 2010; Aquém, além mar. São Paulo: Hucitec, 2000

126 Igel (1988, p.56-57) justifica nossa afirmação com o trecho em que apresenta o gráfico na qual a autora situa o romance $O$ fiel $e$ a pedra em sua obra. Entretanto, mais que o romance referido, um divisor da obra osmaniana torna-se a viagem à Europa: "No setor literário, é possível discernir os dois hemisférios em que se dividiu sua criação romanesca, imaginando-se a viagem à Europa como uma linha a definir as duas metades. No hemisfério anterior ao percurso europeu, localizam-se os dois primeiros livros, $O$ visitante e $O$ fiel e a pedra. O ponto em comum na caracterização de ambos é o conservadorismo em que foram talhados. Neles, o manejo estrutural é tradicional, em que se guarda respeito por uma aderência entre narração e cronologia de fatos, e em que a voz narradora é única, onisciente e de alcance global. Todos os demais elementos que contribuíram para a elevação artística destas duas obras são aqui propositadamente excluídos, ressaltando-se apenas aqueles que estabelecem sua base comum e diferenciadora daquelas outras duas, que surgiram depois da viagem à Europa.” Para gráfico, ver ANEXO 1.
} 
viagem $^{127}$ ), como parte relevante da obra ficcional de Osman Lins, uma obra de preparação do escritor para a segunda etapa de seu projeto literário:

\begin{abstract}
Ele acabou escrevendo um verdadeiro diário sem complicações sentimentais. Não o inovou. Mas não foi o diário tal e qual que veio a público. Osman Lins trabalhou como ficção essa sua experiência, transmitida numa cuidadosa linguagem literária e numa pensada arquitetura estrutural, em Marinheiro de primeira viagem, publicado em 1963, pela editora Civilização Brasileira. Literalmente fragmentada, essa narrativa de viagem prenuncia a composição descontínua de Nove, novena e Avalovara e seu parentesco mais chegado à arte do retábulo e da pintura. (NITRINI, 2004, p.36)
\end{abstract}

A partir de então, acompanhando a obra osmaniana, sua leitura dedicada à comparação entre Literatura e Pintura, trará o ensaio Do fular ao tapete, em que retoma as características picturais da obra osmaniana, à luz do conceito de Daniel Bergez. Além disso, atribuindo atenção especial ao romance Avalovara, analisará as imagens do tecido representado no fular de Roos e da tapeçaria que cobre a sala da mulher feita de palavras.

\title{
3.2 As aulas de História da Arte
}

"As potencialidades da imagem e da palavra gozam de um dom talvez inexaurível: o de formar novas arborescências que dialetizam a expressão da seiva original.” (BOSI: 1986, p.65)

Vê-se, assim, que a fortuna crítica osmaniana reconhece e dedica-se à cara relação entre a obra do escritor e as artes plásticas, principalmente na chamada segunda fase de sua carreira. E, da mesma maneira que, durante as aulas de Teoria Literária, Osman Lins, a partir de sua produção literária, dá o depoimento de sua experiência como escritor - suas preferências, escolhas e dilemas -, nas aulas de História da Arte evidenciam-se suas preferências artísticas, as quais, de forma direta ou indireta, surgirão quer em sua Literatura, quer nos demais pontos do conjunto de aulas do Curso de Literatura Brasileira. ${ }^{128}$

127 ALMEIDA, Hugo (org.). O sopro na argila. São Paulo: Nankin, 2004.

128 De forma despretensiosa, o presente estudo apresentará exemplos pontuais coletados na produção literária osmanaiana, como recurso de caracterização do uso e do diálogo entre sua literatura e as artes plásticas. Mas salienta-se que análises minuciosas estão presentes na fortuna crítica anteriormente referidas no ponto 3.1 . 
Quanto à estrutura do curso, diferentemente da maioria das aulas de Teoria Literária, as exposições de História da Arte são narrativas lineares, sem nenhum tipo de esquema, todas acompanhadas de trilha sonora, que faz fundo à voz de Osman Lins narrador do texto. Ao final, muitas das aulas trazem referência bibliográfica e as informações da trilha sonora. O texto que predomina na composição didática de Osman Lins foi retirado do conjunto de livros editados pelo Museu do Louvre, chamados de Images des Grandes Civilisations, Editions Rencontre / Lausanne, publicados entre 1964 e 1965. Sabemos que a coleção de livros, que apresenta os slides das imagens analisadas, foi adquirida por iniciativa da cadeira de Literatura Brasileira, na época ocupada pelo escritor e pela professora Suzi Frankl Sperber. Também são referenciadas as obras: Crete and Early Greece de Friedrich Matz; La cathédrale de Chartres de Yves de la Porte e La Renaissance en Italie de Bernard de Motgolfier e Michel Gallet.

Do conjunto das oito aulas, foi possível recuperar seis delas:
1) Aula de pintura 1;
2) Grécia clássica e helenismo;
3) Arte Bizâncio-românica;
4) Pintura Românica;
5) Gótico e
6) Renascimento Italiano.

Observando os temas propostos para o curso extracurricular de História da Arte, percebemos, de imediato, que apenas a primeira aula apresenta um título que difere do real conteúdo ministrado. No entanto, tal indicação é significativa, pois, dentre as modalidades artísticas que poderiam ser escolhidas pelo escritor, ele elege a pintura. Ainda tendo por base apenas os títulos, a eleição da pintura se repetirá na quarta aula, voltada à pintura românica. Essa escolha, não aleatória, será justificada, logo no início da narração da primeira sessão. Transcrevo as próprias palavras do escritor: 
Achamos que as artes se relacionam e que uma certa familiaridade com a escultura e a pintura nos oferecem mais alguns instrumentos para abordarmos com segurança maior o problema literário. ${ }^{129}$

Ou seja, o curso estará voltado para a pintura e a escultura, pois os elementos de composição dessas artes servirão de suporte para o trabalho com a Literatura, tema principal da disciplina ministrada por Osman Lins. Essa será a justificativa do escritor diante da proposta de seu trabalho, que podemos chamar de interdisciplinar.

Vale ressaltar que, além do objetivo maior do escritor - oferecer suporte teórico para o problema literário - há outros motivos para a idealização e realização do curso, motivos esses subordinados a seu senso crítico:

\footnotetext{
Tendo em vista a ausência de museus em nossa cidade, e mesmo nas grandes capitais brasileiras, uma vez que o nosso país é bastante pobre em acervos artísticos, decidimos, como parte do curso de literatura brasileira, organizarmos periodicamente pequenas sessões audiovisuais de artes plásticas. Pretendemos, assim, fazer uma retrospectiva indo, dentro do possível, das primeiras civilizações humanas aos nossos dias.130
}

A partir de agora, apresentaremos o conteúdo de cada aula. Ao final do presente trabalho, anexamos as transcrições e, quando possível, as imagens do material original utilizado por Osman Lins.

\subsubsection{Aula de pintura 1}

A aula que inaugura o curso de História da Arte é dedicada ao estudo da Pré-história, Egito, Creta. Por se tratar da aula introdutória, é nela, como mencionamos anteriormente, que Osman Lins se aproveita para expor os objetivos do curso, a saber: suprir uma deficiência curricular e a ausência de espaços culturais na cidade e a partir do estudo de outras manifestações artísticas, fornecer subsídios para o estudo da Literatura, com ênfase em uma programática inter-relação entre as artes.

129 Arquivo do Instituto de Estudos Brasileiros USP - Fundo Osman Lins. Código do documento: Aula de Pintura 1 130 Arquivo do Instituto de Estudos Brasileiros USP - Fundo Osman Lins. Código do documento: aula de pintura 1 
Verificamos que o princípio estruturador não só desta aula, mas de todo o Curso de História da Arte é apresentar como o homem, de maneira insistente, criou ao longo do tempo, diferentes formas de representar a realidade.

A primeira coisa que nos chama a atenção, quando nos ocupamos das artes é a insistência, dizemos melhor, a persistência com que elas têm acompanhado desde a mais remota antiguidade a aventura humana.

A partir das palavras do professor Osman Lins, transcritas abaixo, ao aluno mais atento ficará explícito o paralelo entre as aulas de Teoria Literária e as aulas de História da Arte, bem como o interesse do escritor Osman Lins. Esquematizemos no quadro abaixo:

\begin{tabular}{|c|c|}
\hline $\begin{array}{c}\text { Curso de Literatura Brasileira } \\
\text { Aula de Teoria Literária }\end{array}$ & $\begin{array}{c}\text { Curso de História da Arte } \\
\text { Aula de pintura } 1 .\end{array}$ \\
\hline Não transmitir, com métodos tradicionais, uma visão nova & (...) os artistas, tanto os primitivos como os civilizados, \\
das coisas; mas criar uma obra que seja através dos seus & tendem a modificar a natureza, a criar formas e imagens \\
meios expressivos, esta visão nova posta em termos & que não constituem apenas uma cópia, uma repetição das \\
romanescos. ${ }^{131}$ & formas existentes. A arte busca sempre uma transfiguração, \\
& uma visão rebelde e se possível nova do real.
\end{tabular}

Não por acaso, o primeiro artefato primitivo apresentado por Osman Lins é uma lâmpada da Idade do Paleolítico.

131 Arquivo do Instituto de Estudos Brasileiros USP - Fundo Osman Lins. Código do documento: OL/MAG/CX02/P01/07. Também usada como ilustração na nota 14 . 


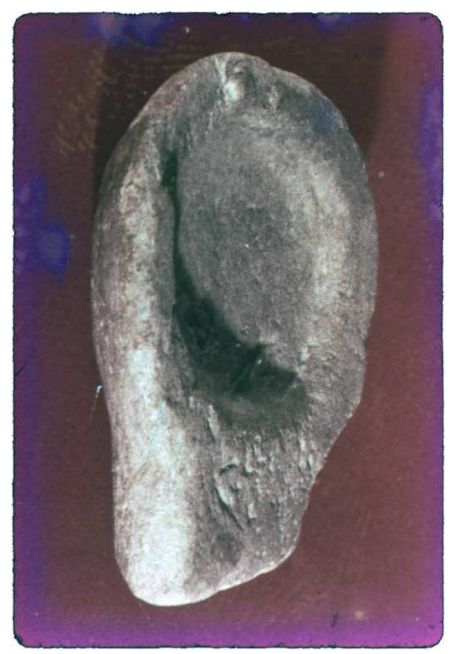

GC_1-01

Essa lâmpada tem valor simbólico múltiplo. Nas palavras do próprio autor ela é "símbolo da ânsia humana de, através da arte, ver um pouco na escuridão do mundo”. Novamente, não deixa de ser esse o papel do artista e do escritor. A lâmpada tem ainda uma outra função de destaque nas sociedades primitivas: ela presidia, nas "antigas noites humanas", as reuniões, as festas e as cerimônias e, assim, "talvez os primeiros contos". Esse é um ponto de vital importância para o escritor Osman Lins: oferecer um vislumbre das origens da narrativa, como um impulso que, desde os primórdios, fez parte da experiência humana - uma justificativa da legitimidade de seu próprio ofício. Por fim, esse objeto, colocado no pórtico das aulas, sugere também o caráter iluminador do curso de História da Arte.

Esta aula, como também o restante do curso, segue a seguinte estrutura: Osman Lins apresenta elementos históricos e geográficos dos povos e regiões que serão estudados, e descreve, de forma razoavelmente cronológica, os objetos artísticos produzidos e os conceitos estéticos que os conformaram. Nesta aula, em particular, os tipos de objetos discutidos são: pinturas rupestres, e instrumentos de caça, esculturas, vasos e jarros, baixos relevos e frisos, testemunhos escritos, utensílios domésticos, afrescos e objetos mortuários. Esses objetos refletem temas como fecundidade, paz e guerra, vida campestre e cotidiana, luta do homem para a conquista da terra, morte e vida após a morte. Os conceitos estéticos que o professor pretende ilustrar aos seus alunos são: esquematismo, 
geometrização e estilização das formas, simetria e assimetria, perspectiva, rigidez e movimento, sobriedade, lei da frontalidade e epifania.

De especial importância é a discussão sobre os testemunhos escritos dos povos primitivos, afinal é um professor que leciona em um curso de Literatura. Entre essas manifestações, a mais destacada é o Código de Hamurabi.

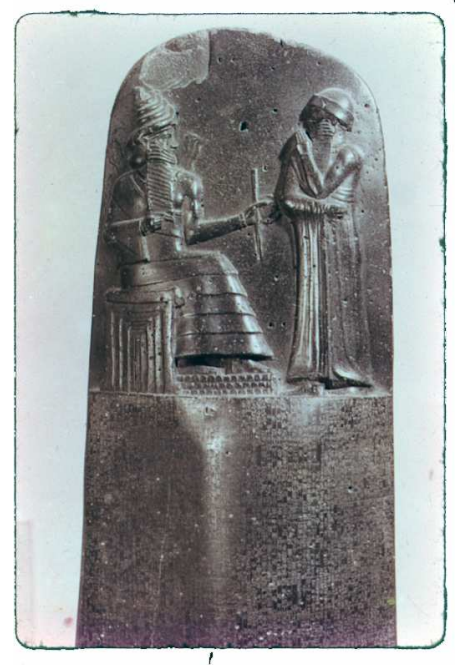

GC_1-13

Osman Lins ressalta o caráter divino do documento, e como, pela dureza da pedra, a representação artística de sua composição, simboliza o desejo de sua permanência. Também a escrita egípcia, "bela e misteriosa", merece referência. A sua decifração por Champollion é considerada uma das grandes descobertas históricas, pois "antes disso, era como se os monumentos egípcios fossem mudos". Osman Lins se permite inclusive uma observação metafórica: "De súbito, porém, os mortos silenciosos nos falaram. Ouvimos a voz dessa mulher, desse homem”. Tanto nas referências ao Código de Hamurabi, quanto à escrita egípcia, percebemos a intenção, talvez inconsciente, da valorização do texto escrito, ora dotado de status divino ora servindo de testemunho privilegiado de uma civilização, complementar aos seus monumentos e obras de arte.

A escrita, segundo Osman Lins, representaria o ápice da tendência do homem primitivo de criar representações cada vez mais econômicas e abstratas do seu mundo, "substituindo por uma forma conceitual, a força viva". Essa tendência, no entanto, permanece nos objetos artísticos per se. Em 
verdade, o esquematismo, a geometrização e a estilização das figuras é a técnica predominante das civilizações estudadas, fato para o qual Osman Lins dá grande ênfase. Seu interesse por esses procedimentos não é gratuito: o autor, reconhecidamente, vale-se de esquemas e formas geométricas para compor suas narrativas, especialmente a partir de Nove, novena. Já é lugar comum destacar a estrutura da espiral e do quadrado que rege o romance Avalovara e em Nove, novena uma das epígrafes não deixa dúvidas: "Uma concepção geométrica sintética e clara fornece sempre um bom plano. Matila C. Ghyka, Esthétique des proportions dans la nature et dans le arts". Além disso, na obra de Osman Lins, o esquematismo se fará presente pelo uso de símbolos gráficos que representam personagens. Em última análise, as técnicas artísticas usadas pelos antigos revelam a falta de "preocupação com a representação realista do modelo" e a "tendência transfiguradora da arte", característica fundamental presente na fase madura de Osman Lins. Não é a toa que os objetos analisados recebem qualificações como "caprichosos", “requintados", "notáveis", “interessantíssimos”.

Aliados aos conceitos acima, estão os de rigor e sobriedade, especialmente relacionadas à arte egípcia, e também caros a Osman Lins. Em paralelo com a complexidade das suas tramas narrativas, é possível depreender uma busca pela precisão e até mesmo por uma contenção: “Em Osman Lins identifica-se logo uma atitude de sobriedade e de comedimento. Eduardo Portela (encarte da primeira edição de Avalovara)". Essas qualidades serão destacadas durante a aula através de expressões como: arte "sóbria e rigorosa", em que se acham "linhas de grande simplicidade"; "economia de esforço"; e o conceito de "hieratismo".

Outro conceito central na aula é o de epifania, como "a revelação divina, indicada, em geral, nas obras de arte, por um pássaro". Osman Lins aproveitará esse conceito e a figura do pássaro no romance Avalovara. Nele, o místico e o transcendental estão também simbolizados no pássaro, que se manifesta no próprio título do livro - Avalovara -, e é a imagem que representará a busca de Abel pela composição de seu livro e de sua vida. Assim, vida e morte estão no cento da aula e do romance. Ao final da narrativa 'A mulher feita de palavras e Abel: o Paraíso', no momento de consumação da plenitude do amor vivido pelos personagens, Osman Lins apresenta a morte como solução para a união 
definitiva. Será ela a porta para a transcendência. Nesse momento fulcral, a imagem do pássaro toma proeminência:

\begin{abstract}
“(...) nós esperamos calados os ternos dedos no meu rosto juntam-se as placas de aço abrese o pássaro de pássaros toda a minha vida se concentra no ato de buscar sabendo ou não o que pesada como chumbo perde-se nas nuvens a fuliginosa ave de canto ignóbil o Portador na mão direita a morte o fim a conclusão o pássaro dentro de nós agita as asas de seda e canta com bondosa voz humana Olavo Hayano o cabelo negro e branco os dentes grandes e vazia devorada uma banda da cara volta para nós o cano vemos bem o seu gesto e não sabemos o que significa, nada sabemos além do reconhecimento e da beatitude, as figuras antigas e rescendentes a flores e a guardados seus bandos plastrons rendas chapéus continuam imóveis e voltadas para o portador, ele abre a boca exicial e vários cães ou abonaxis latem de uma vez, canta apaziguador o nosso pássaro mais forte o nosso abraço, novo relâmpago na sala e ouvimos irado cheio de dentes irados o ladrar dos cães e cruzamos um limite e nos integramos no tapete somos tecidos no tapete eu e eu margens de um rio claro murmurante povoado de peixes e de vozes nós e as mariposas nós e girassóis nós e o pássaro benévolo mais e mais distantes latidos dos cachorros vem um silêncio novo e luminoso vem a paz e nada nos atinge, nada, passeamos, ditosos, enlaçados entre os animais e plantas do Jardim." (Avalovara, p. 412-413)
\end{abstract}

Assim como os corpos de Abel e da mulher feita de palavras entrelaçam-se ao tapete, começamos a perceber a rede de idéias e imagens presentes na criação literária de Osman Lins, que não separa seus ofícios de escritor e professor, ao mesmo tempo que une Literatura e Artes Plástica, em sua obra e em suas aulas.

O último objeto apresentado por Osman Lins nesta aula é uma máscara mortuária. Enquanto a lâmpada do início representava a luz e a vida, a máscara que fecha a aula quer significar a morte e também a cegueira. É o próprio Osman Lins que deixa isso explícito aos seus alunos: "Concluímos com ela, simbolicamente, por dois motivos a aula de hoje: sobreviver à morte não parece ser uma das finalidades da arte? Por outro lado, vemos nos olhos fechados da máscara uma imagem da nossa própria cegueira em face do universo. Uma cegueira que a arte busca ultrapassar”.

\title{
3.2.2 Grécia clássica e helenismo
}

A segunda aula traz como tema a Grécia clássica e helenística. Osman Lins reconhece, como de praxe, a influência da civilização grega no mundo ocidental, sentida até os nossos dias pela 
valorização e apropriação de sua cultura: a política, o teatro, a filosofia, a arquitetura, a Literatura e as demais expressões artísticas. Diz o autor:

\begin{abstract}
Nenhuma das antigas civilizações exerceu tanta influência sobre a arte ocidental quanto a civilização grega. (...)As imensas e harmoniosas colunatas dos seus edifícios públicos continuam a repercutir, transformadas ou simplesmente imitadas, em muitas construções do nosso tempo. (...)Filósofos como Platão e Aristóteles, escultores como Fídias, dramaturgos como Sófocles, poetas como Anacreonte, arquitetos como Hiptnos, responsável pelo Partenon, são alguns dos nomes com os quais dialoga ainda hoje o homem culto do ocidente. $^{132}$
\end{abstract}

Convém, primeiramente, situarmos esta aula dentro do projeto pedagógico do escritor de mapear as formas de representação da realidade efetuada pela criação artística. Enquanto, na aula anterior, a realidade era transfigurada a partir de técnicas como a geometrização e a estilização, gerando figuras mais abstratas e esquemáticas, a arte grega aproxima-se de um maior realismo, muitas vezes ultrapassando-o, em busca da harmonia, da perfeição, da beleza ideal. Apesar de não ser explicitamente nomeado por Osman Lins, um dos conceitos básicos da arte grega é o belo composto. Segundo os estudos da estatuária grega, a composição do corpo é feita a partir da divisão deste em sete partes, gerando uma harmonia matemática que produz a simetria das formas e conseqüentemente, alcança o status do belo.

A matemática não estará presente apenas nas esculturas gregas. Platão, ao apresentar a técnica do bom discurso, dirá que este deve ser ordenado e o orador deve seguir os passos de um bom açougueiro, que realiza um corte matemático nos excessos ${ }^{133}$. Encontramos, portanto, outra aproximação entre a seleção feita por Osman Lins para sua exposição de História da Arte e a sua obra literária: o trabalho dedicado do artista, e a ordem matemática - traços tantas vezes apontada pelos estudos críticos de sua obra. E voltando à temática da aula, o conceito do belo composto emerge:

Aqui, um precioso exemplar da chamada fase Clássica. O que o caracteriza? Um acentuado realismo, inclinação decidida para o figurativo e completando das tendências uma concepção ideal, quase matemática, da beleza das formas. Já tivemos oportunidade de acentuar a tendência universal da arte para recriar a natureza. Ao invés de copiar de um

132 Arquivo do Instituto de Estudos Brasileiros USP - Fundo Osman Lins. Código do documento: XXXXX

133 Já utilizado como argumento anterior, o artigo Reflexões do jovem escritor, (NITRINI: 2010), traz as anotações resgatadas de caderneta do escritor, apresentam as reflexões do início de seu projeto literário. Dentre elas está: "Creio que já escrevi uma vez: nada é mais funesto a uma obra de arte literária (ou qualquer outra) que a piedade, ou melhor, o apêgo material a certos trechos do trabalho que custaram o nosso esforço, mas cuja composição difere do conjunto. Sobretudo a Unidade" (NITRINI: 2010, p. 32-33) 
modo servil o mundo, tende o artista a inventar novos mundos. A arte clássica grega assinala um dos raros momentos em que a recriação artística vai manifestar-se não através de uma geometrização ou violação das formas e sim através de uma intensificação ou idealização. Vê-se claramente o que afirmamos neste Hermes sustentando Dionísio.

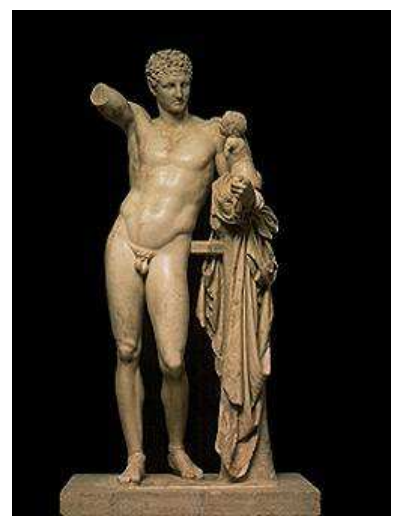

A superação da natureza será um tema caro ao Renascimento, como veremos adiante, na aula específica sobre o período. Matemática e geometrização, também estavam presentes na arte egípcia, apresentadas na seção anterior. Dessa forma, o plano pedagógico traçado pelo escritor começa a se apresentar, e, durante todo o material, veremos referências para tópicos que já foram expostos ou que serão apresentados mais tarde.

Apesar da obra de Osman Lins não poder ser chamada de clássica, harmoniosa e serena, o professor e o apreciador de arte não esconde o seu entusiasmo pela arte grega, utilizando-se de expressões como "composição vigorosa e pungente", "precioso exemplar", "apuro da escultura grega", "ritmos sutis", “desenho depurado", "delicadeza apurada e comovente", "grande elegância", visualizamos, de certa forma, o fascínio de um artesão do reino literário pela habilidade compositiva de outros mestres. Em especial, o autor exalta o modo de representação de um ideal da beleza da mulher feita pelos artistas gregos, onde, segundo ele, "a escultura grega vai atingir os seus pontos mais altos”. No entanto, segundo Ferreira (2005), “as figuras femininas de Osman Lins, traçadas ao estilo da pintura clássica, são, contudo, despedaçadas por um gesto demolidor, transformadas em mulheresespaço, mulheres-mosaicos. Tal como Magritte, na pintura, Osman Lins parece desejar para a literatura, pela conservação/ negação da representação mimética, um afastamento do vínculo com a realidade" (p. 203).

Dignas de nota por ser próprio da atitude de um literato, são as inserções, durante a aula, de trechos de textos de Platão ou de poemas de Anacreonte, que servem de glosa ou comentário às obras 
apresentadas. Assim, por exemplo, sobre uma das vitórias, Osman Lins justapõe um excerto de composição de Anacreonte:

"Ó tu, mais sábio e gracioso dos pintores louvados por Rodes, eleva a tua arte ao nível superior e traça os encantos de minha amante ausente. Veste-a de púrpura e faz que de seu corpo uma parte adorável surgindo dentre as dobras de seu manto, faça-nos entrever os tesouros que ali esconde ao nosso olhar."

Essa estratégia de Osman Lins de ilustrar as obras por textos literários também se manifesta em uma comparação entre obras de arte de diferentes épocas, mas que possuem elementos técnicos ou temáticos semelhantes, tornando a aula mais rica ao mostrar que a arte não pode ser limitada a só um tipo de expressão ou cronologia. Assim, ao falar de um mosaico que representa a batalha de Issus:

Outro mosaico, representado a batalha de Issus, onde Dario é vencido por Alexandre. Data do século II antes de Cristo.

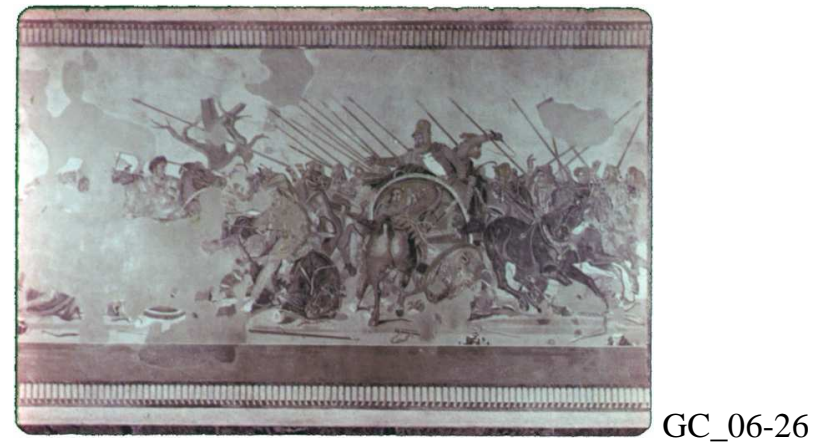

Neste ponto, Osman Lins dá um salto temporal e compara o mosaico do século II a.C. com uma pintura de Uccello, pintor Florentino do Renascimento, preocupado em retratar em sua obra conceitos de perspectiva e cor. A perspectiva da pintura assemelha-se ao foco narrativo da Literatura. E a escolha de uma obra representada em três quadros já será o anúncio das preferências artísticas de Osman Lins, pois, a sua maneira, a pintura de Uccello, além do passado, dialoga com o futuro, ao anunciar os retábulos, que tanto encantam Osman Lins:

A título de curiosidade, vale a pena compará-la com essa batalha de Uccello, pintor florentino morto em 1475. 

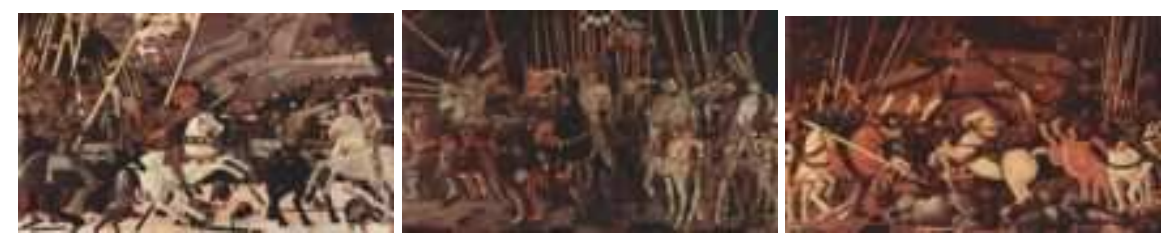

Dezesseis séculos separam as duas obras, entre as quais se nota, entretanto, grande semelhança de composição.

Tal como na primeira aula, o encerramento desta é significativo. A imagem de fechamento é a Vitória de Samortrace, reconstituída a partir de 118 pedaços. Diz Osman Lins: "O longo esforço no sentido de restaurá-la, não é um pouco a imagem da atividade artística, através da qual, dentre outros objetivos, buscamos uma unidade perdida?". Ao lembrarmos da estrutura de Avalovara, composto de linhas narrativas independentes, que em determinado ponto relacionam-se, formando a obra, podemos também especular que seu objetivo também seja reconstituir algum tipo de unidade perdida.

\subsubsection{Arte Bizâncio-românica}

Dentro do plano osmaniano de ilustrar as maneiras como a arte representa a realidade, este período, em comparação com o anterior, deixa de representar "a glória do corpo e as vitórias humanas", para enfatizar "as vitórias e as glórias de Deus". Do mundo grego, vasta era que abrange dos séculos VII a.C. a I d.C., passa-se à arte bizantina, que abarca dos século V ao XIII d.C.

Com o intuito de fortalecer o cristianismo, a igreja católica adota a política de acolher (e atrair) novos fiéis, fazendo uso da arquitetura das igrejas, suas pinturas e mosaicos, como ferramentas para a catequização do povo cristão. A escolha por uma arquitetura sóbria na representação externa das igrejas contrastava com seus adornos internos, feitos com pinturas e mosaicos. Dessa maneira, a arquitetura bizantina, de forma simbólica, representará o que será o corpo visto pela concepção cristã: por fora, o desapego ao adorno sugere o desprendimento pelas superficialidades e ostentação da matéria. Em contrapartida, seu interior, onde está abrigada a alma, será revestido de riqueza e preciosidade. Também os motivos abordados pelas obras são, segundo o próprio Osman Lins explicita, de natureza bíblica. 
Este período permite que Osman Lins ofereça como exemplo um tipo de objeto artístico que lhe é caro, por servir virtualmente de modelo para muitas de suas narrativas: o mosaico. Como já observamos anteriormente, muitos dos textos do escritor são formados de linhas narrativas cronológica e espacialmente independentes que obrigam uma síntese por parte do leitor para que eles possam ser reconstituídos - assim também o mosaico, composto de vários fragmentos, forma uma única figura.

O mosaico, "expressão por excelência da arte bizantina", juntamente com os retábulos e as ilustrações de manuscritos, compartilham o mesmo traço do período: "suntuosidade" e "magnificência das cores". Esses efeitos são obtidos pelo uso de esmaltes, pedras preciosas, filigranas de prata e ouro e dimensões avantajadas. Dos mosaicos, em especial, Osman Lins falará da "imortal e fascinante beleza dessas obras", e do mosaico que representa a Imperatriz Teodora e sua corte, localizado na igreja de São Vital em Ravena, caracterizado como um "majestoso e cintilante mosaico”, em que se percebem “notáveis gamas de cores e a pulsação de vida".

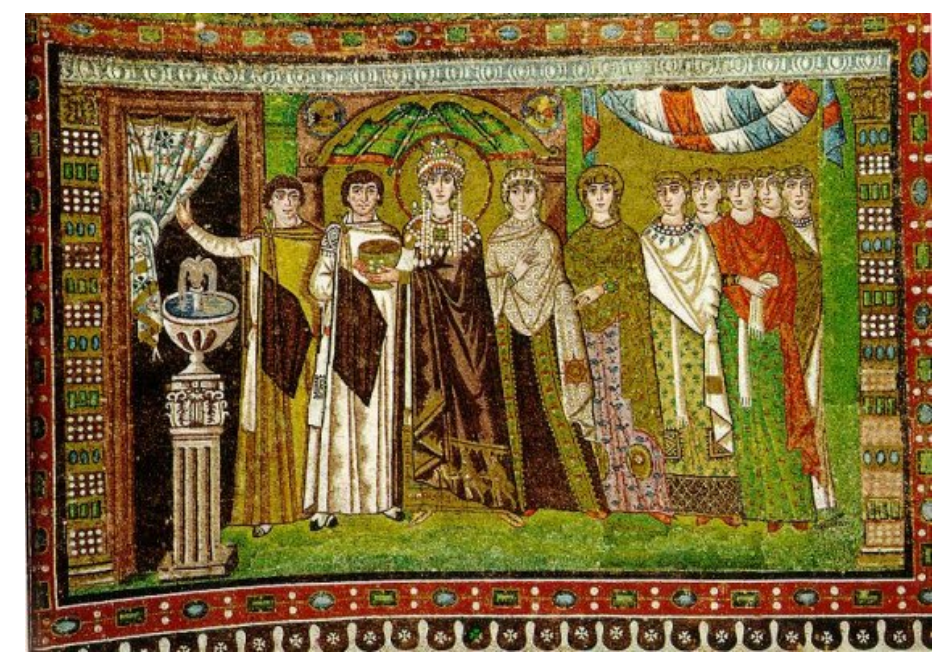

O fascínio de Osman Lins por luzes e cores pode ser encontrado em alguns momentos de sua obra, muitos deles tendo associado uma obra de arte ou objeto arquitetônico. Em Os gestos, livro da primeira fase osmaniana, o conto "O vitral" trará, no próprio título, o artefato que sublima os dois elementos - luz e cores - que também estarão presentes na descrição espacial da breve narrativa: paredes, mas não com as alegrias sonhadas, sem o que tudo o mais se tornara inexpressivo. (...) 
Abriu a porta, saíram. Flutuavam raras nuvens brancas; as folhas das aglaias tinham um brilho fosco. (...)

Seguiram. Soprou um vento brusco, uma janela se abriu, o sol flamejou nos vidros. (...)

(...) Nenhum vitral retém a claridade. (LINS: 1994, p. 82-83)

Em Marinheiro de primeira viagem, livro que marca a transição da obra osmaniana, a descrição presente no trecho "A Môça" relata a luz que compõe uma espécie de quadro134:

A cabeça inclinada, lia com atenção. O sol iluminava em cheio as páginas do livro, suas mãos, parte da blusa, o rosto, a cabeleira. Ele contemplava, orlada por um fio de luz que era o gume daquele perfil, a face sombreada; esta, porém, parecia esplendente como se fora de vidro, recortada contra a janela do vagão, através da qual ele via o campo nu, ensolarado e frio, com seus ramos secos. (LINS: 1963, p. 5)

Nove, novena traz no conto "Noivado", também o sol e um vitral que protagonizam uma cena plástica e fulgurante:

Vou de ônibus. Ao passar ante o Colégio da Sagrada Família, um pássaro desliza sobre a relva e, erguendo vôo, orienta-se em direção à rosácea da capela. Com o movimento do ônibus, há um instante, uma fração de segundo em que o vitral chameja, refletindo o sol, numa palpitação breve e cegante. (LINS: 1994, p. 165)

Por fim, em Avalovara, luz e cor dão o tom da narrativa R:

(...) Mergulho, olhos abertos, sob o seu corpo e deslizo sobre o corpo que flutua e creio ver, meio ofuscado, entre os reflexos, outro corpo: vejo, como se os reflexos das águas penetrassem-na, pontos luminosos, roxos, verdes, brancos, não simples reflexos, signos. (Letras?) (LINS: 1973, p. 62)

Surpreendemos certa semelhança entre esses trechos citados e uma própria passagem da aula:

A luz exterior, penetrando pelas aberturas da igreja, modifica a iluminação desses murais e faz vibrar as cores com prodigioso número de matizes. Segundo o teor da luz, os mesmos tons ressoam diferentemente. 
Outro ponto que interessa a Osman Lins é a capacidade dos artistas bizantinos de produzirem grandes obras sob as "coerções estilísticas" do período. Afinal toda arte tinha como finalidade principal a propagação da fé e procurava representar ou a "grandeza imperial", ou "o esplendor de Deus". Em certa medida essa também é uma preocupação do próprio escritor, como vimos no capítulo 1 desta dissertação, cuja liberdade está limitada economicamente pelo mercado, estilisticamente pela cultura de massa e politicamente pela censura.

\subsubsection{Pintura Românica}

Esta aula, em certa medida, complementa a anterior. Enquanto aquela tratou especialmente dos mosaicos bizantinos, esta aborda a arquitetura, os afrescos, as esculturas e as iluminuras românicas, também motivadas pela ideologia cristã. Para Osman Lins o românico representa um certo retorno ao esquematismo, estilização, sobriedade e simplicidade dos povos antigos, aqui subordinados a outros propósitos. Ainda assim, o autor não deixa de considerar essa arte "poderosa, expressiva e original". Para ele, a "força concentrada e severa" das obras "compensa as deficiências de composição".

De fato, Osman Lins enfatizará reiteradamente como, nas suas diversas manifestações, a "simplicidade de meios" utilizados pelo artista românico "não afeta a beleza e a grandiosidade da representação", ou, posto de outra forma, a "eficácia expressiva da obra". Um dos exemplos dessas limitações técnicas é a ausência de perspectiva em afrescos, retábulos e iluminuras.

O que para os artistas romanescos é apontado aparentemente como limitação, para Osman Lins, na composição de sua obra, o aperspectivismo é um recurso conscientemente empregado. Exemplo disso encontra-se na fase madura do escritor, inaugurada pelas narrativas de Nove, novena. Em entrevista concedida em 1976, Osman Lins aponta sua primeira viagem à Europa e o contato com vários tipos de arte, entre elas a românica, como principal ponto a ser considerado:

Gostaria só de acrescentar que esta minha temporada na Europa foi muito importante, porque eu a levei muito a sério, estabeleci programas muito rígidos de visitas a museus, concertos, de visitas a determinadas cidades, (...). E a viagem me marcaria muito porque 
nela viriam a se definir certas coisas que já se esboçavam no meu espírito antes de partir. Eu diria que a principal experiência desta minha temporada, que me marcou e marcará o resto da minha vida, foi o contato com os vitrais e com a arte românica, a arte medieval em geral. (LINS: 1979, p. 212)

\section{A crítica corrobora o autor:}

O que mais o marcou em sua primeira viagem à França foi o contato com os vitrais, com a arte românica e a arte medieval em geral. Percebeu que o aperspectivismo não é uma preocupação exclusivamente sua. Localiza o início dessa visão nos tempos modernos, nos poetas Apollinaire e Mallarmé e no romance de Faulkner e em algumas narrativas de Virginia Woolf. Nesse sentido ele se insere nessa tradição moderna, a partir de Nove,novena e contradiz parte da crítica que insistiu em lê-lo com as chaves do Novo Romance. (NITRINI: 2011, p. 108)

Ainda sobre o tema da "simplicidade de meios", temos acesso a uma explicação mais esclarecedora de Osman Lins: "as coisas fulguram, vamos dizer, nas suas limitações. As limitações não são necessariamente uma limitação no sentido corrente, mas uma força." (LINS: 1979, p. 212)

$\mathrm{Na}$ aula, tais aspectos são desenvolvidos:

Há no desenho uma certa ingenuidade e não se pode falar aqui de claro-escuro ou de perspectiva. É como se esses artistas, cujos nomes muitas vezes ignoramos, buscassem apenas, em suas sínteses, a essência das coisas. Essa busca da essencialidade vamos encontrá-la sempre com um acentuado caráter primitivo, mesmo em motivos profanos. Como nesta cena de caça à lebre, afresco da capela de Berlanga, em Castela, da primeira metade do século XII. São apenas sugeridas as árvores e rígidos os movimentos. Nenhuma perspectiva.

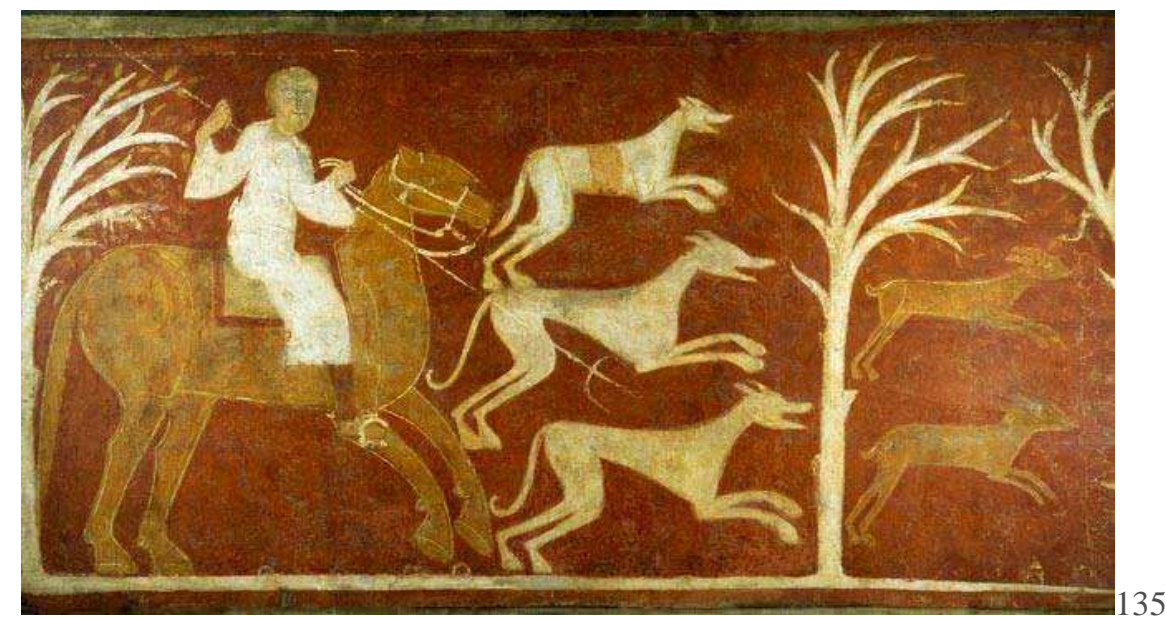


E dentre os motivos profanos apresentados por Osman Lins, não gratuitamente, na seqüência das imagens analisadas, surge a referência a um elefante:

O mesmo fenômeno neste portentoso elefante de combate, animal provavelmente desconhecido do pintor.

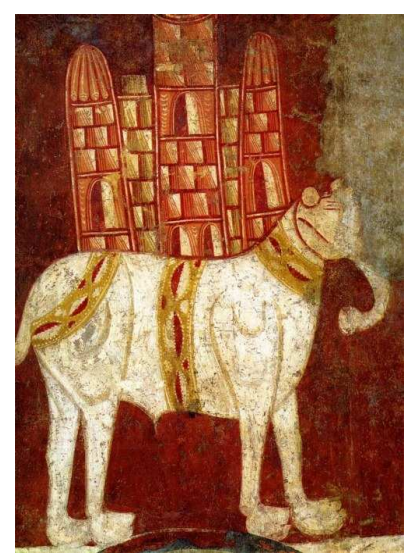

Na narrativa "O Pentágono de Hahn”, presente em Nove, novena a figura central também é uma elefanta - Hahn - que dá nome ao conto. O pentágono é formado a partir de cinco linhas narrativas que são personagens que, dialogando consigo mesmos ou com os demais, formam simbolicamente o pentagrama, figura geométrica composta de cinco pontas. Nesta imagem simbólica, a elefanta estaria no centro da figura. O que nos chama a atenção - mais do que o animal presente no conto e no afresco apresentado em aula - será a relação feita por Osman Lins, entre o texto da aula e a fala de Armando136, um artista, e seu irmão, identificado como um homem celibatário:

(...) Também Armando recusou ir comigo:

- Muita gente.

- Já foi lá?

- Não.

- Você não gosta de pintar bichos?

- Não se trata de gostar. É uma necessidade.

- Mas por que não vai ver um elefante de perto?

- Não preciso vê-lo. Sei muito bem como é um elefante.

- Isso é o que você pensa. (...) (LINS: 1994, p. 43-44)

Outro conceito que recebe destaque nesta aula é o grotesco. Esse conceito já havia sido mencionado, de passagem, na aula dedicada ao período helenístico, quando da apresentação de uma escultura chamada "Velha bêbada": 


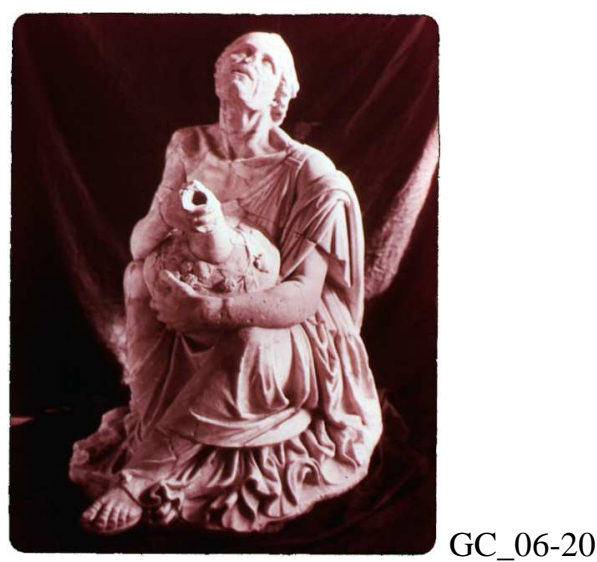

Aqui, o grotesco será mais bem explorado, inclusive a partir de um procedimento inédito e único no Curso de História da Arte: a referência a uma fonte bibliográfica de apoio - o ensaio $O$ Grotesco, de Wolfgang Kayser. O grotesco, para a exposição osmaniana, configura-se como outra técnica de representação do real, diferente das já estudadas. Ele representa o "fracasso da simples orientação física do mundo", um "jogo com o absurdo" (definições que misturam as palavras de Osman Lins e de Kayser). O autor também qualifica a importância do grotesco na época românica como "notável", por beber na imaginação popular um mundo recheado de "demônios e representações do horror", gerando, no entanto criações "ingênuas, vigorosas e expressivas”. Em última análise, para Osman Lins, o grotesco é “um modo também de interrogar o mundo e a condição humana”.

A aula termina com a discussão de códices e suas iluminuras, esta última, segundo Osman Lins, "uma das mais delicadas [artes] que o gênio humano tem concebido". Percebe-se assim, que o interesse do autor pela história da escrita contamina não somente mais de uma aula do Curso de História da Arte, como também tal forma já tinha sido tema de uma das aulas de Teoria Literária.

\begin{tabular}{|c|c|}
\hline $\begin{array}{l}\text { Curso de Literatura Brasileira } \\
\text { Aula: Códices e incunábulos }\end{array}$ & $\begin{array}{l}\text { Curso de História da Arte } \\
\text { Aula: Pintura românica }\end{array}$ \\
\hline $\begin{array}{l}\text { (...) O papiro. Fabricação. Depois da trama, o martelo; } \\
\text { polimento com Pedra-pomes ou dentes. Goma. Óleo de } \\
\text { cedro. (...) } \\
\text { Etapa seguinte: PERGAMINHO. Pele de carneiro ou cabra, }\end{array}$ & $\begin{array}{l}\text { Um informe: aos livros manuscritos dá-se o nome } \\
\text { específico de códice. Os primeiros livros impressos, por } \\
\text { outro lado, denominam-se incunábulos. Na época românica, } \\
\text { anterior à invenção da imprensa, inexistem incunábulos. }\end{array}$ \\
\hline
\end{tabular}


macerada em cal e polida.

Continua sendo escrita de um só lado, uma só face.

O corte e sobreposição (libri quadrati) já anuncia o livro

como o conhecemos. Sua denominação: CÓDICE.

Em uma comparação tripartida, as aulas de Literatura Brasileira, o Curso de História da Arte e a obra literária de Osman Lins, representada aqui por Avalovara, compartilham o mesmo tópico: as

iluminuras. Na mesma aula sobre códices e incunábulos encontramos:

1450. Os novos "manuscritos", sobre velino e papel.

Papel: século XII, origem China, através árabes. Desconfiança: funciona como ersatz. Notários de Gênova: escrevem nas margens de manuscritos árabes. Pouco a pouco ganha terreno.

Segunda metade do séc. 14, já substitui largamente o pergaminho.

200 anos.

Os tipos móveis: ancestral: a xilogravura. As grandes iniciais já se beneficiavam de moldes.

Já conhecida a técnica de impressão sobre linho ou seda, vinda do Oriente.

Cerca de 70 anos antes que apareça o LIVRO IMPRESSO, voga das imagens religiosas em xilogravura.

(...)

Conhecemos bem a aparência de tais manuscritos: as iluminuras etc.

$\mathrm{Na}$ aula sobre a arte românica, as iluminuras são mencionadas com destaque e entusiasmo:

"Folhear um desses livros é atravessar um mundo alegre e colorido, cheio de ornatos."

$\mathrm{Na}$ aula Arte Bizâncio-Românica, os manuscritos e suas ilustrações também estão presentes:

Menos riqueza do material, mas idêntica preocupação com a magnificência das cores, observava-se também nos seus manuscritos. É o que vemos nesta ilustração, representando a passagem do Mar Vermelho.

E por sua vez, na obra literária, o pássaro Avalovara que dá nome ao romance, é comparado a um manuscrito iluminado, com destaque para seu esplendor de cores:

Ataviado com todas as cores dos pavões, o Avalovara lembra um manuscrito iluminado. Nele, quase é possível ler. A cauda é longa e curva, com reflexos de cobre. As asas, seis, de um tom verde celeste quando repousadas, ostentam na face interna, quando abertas, círculos de muitas cores, dispostos com simetria sobre fundo escarlate. (...) Traçadas no seu peito, faixas e fitas roxas. Da delicada cabeça, parecendo ornada com um diadema de pequenas flores e encimada por uma espécie de língua, descem longas plumas muito claras, semelhantes a flâmulas. Rosa brilhante o resto do corpo. Bico rubro e curto, olhos oblíquos. (...) (LINS: 1973, p. 281) 
Com estas mesmas cores, a aula dedicada à pintura românica é finalizada, quando Osman Lins relembra aos alunos os mesmos matizes da arte bizantina e anuncia as luzes multicoloridas dos vitrais góticos que seguirão na próxima aula:

\begin{abstract}
A beleza reside no conjunto e expressa-se, notadamente, no colorido. Um colorido no qual ainda pressentimos ressonâncias bizantinas e que a seguir, viria a esplender dos magníficos vitrais da fase gótica.
\end{abstract}

\title{
3.2.5 Gótico
}

Esta aula apresenta uma estrutura diferenciada em relação às demais. Enquanto naquelas, Osman Lins inclui objetos cronológico e geograficamente variados, nesta, todos os elementos do gótico que o escritor-professor deseja dar a conhecer a seus alunos serão localizados em um só monumento: a Catedral de Chartres. Nesse sentido, Osman Lins faz as vezes de um guia turístico, utilizando mesmo, em diversas passagens, a primeira pessoa do plural. Assim, por exemplo, ao exibir a imagem da entrada principal do templo, ele convida os alunos: “Aproximemo-nos. Observemos a porta central"; ou, ao mostrar uma vista aérea da catedral: "voemos e contemplemos mesmo a coberta de cobre".

Osman Lins, durante essa visita guiada, não esconde seu entusiasmo e maravilhamento diante dos objetos arquitetônicos e ornamentos mostrados, usando expressões como "proporções felizes", “esplêndida ornamentação", "riqueza de invenção", "grandiosidade da concepção", "minúcia da execução", "caprichosas soluções arquiteturais", "colorido rico e harmonioso", "deslumbrante pormenor", “admirável equilíbrio". Ou, observação extremamente enfática: "Não há, pode-se dizer, um só ponto nessa imensa obra de arte que dispense o nosso olhar e o nosso exame". Em outro momento, a sensação de fascínio é tão avassaladora, que o professor recusa mesmo fazer uma análise: “A composição, por assim dizer, dispensa comentário". Esse tipo de postura, em sala de aula evidencia 
um profissional do ensino que não se limita a transmitir informações objetivas, mas que deseja algo quixotescamente: comunicar as próprias sensações de se estar frente-a-frente a grandes obras de arte. Além disso, a própria aula, em certas passagens, reveste-se de um caráter estético literário: o professor, contaminado pelos materiais apresentados, assume temporariamente a máscara do escritor:

O melhor modo de aproximar-se de Chartres, dizem os conhecedores, é pela estrada de rodagem vindo de Paris. A catedral surge no horizonte, desaparecendo e surgindo ao sabor das ondulações. Se estão maduros os imensos campos de trigo, a catedral, como um imenso navio, parece navegar solitária sobre este mar dourado.

Essa ambigüidade entre descrição e criação literária também está presente em Marinheiro de Primeira Viagem. Não gratuitamente, selecionamos um trecho em que, diante d'A Batalha de Uccello - composição usada por Osman Lins na aula dedicada à Grécia - a narrativa emerge:

(...) A Coroação da Virgem, de Fra Angélico, antecipação da visita que haverá de fazer, logo mais, ao Convento de São Marcos. Veronese. Andréa Del Sarto. A Batalha, de Uccello, com seus potentes e oníricos cavalos. Monta num cavalo azul, atravessa as salas, compassadamente. Madonas seguem-no (...). (LINS: 1963, p. 87)

Em se tratando de uma aula dedicada a Chartres e aos vitrais, objeto artístico que explicitamente sempre encantou o escritor, não há como esconder a paixão e o envolvimento de Osman Lins pela Literatura e pela arte gótica. Estes caminham juntos, desde a primeira fase de sua literatura, com o já citado conto "O Vitral", de Os gestos. Nele, a protagonista Matilde é a personificação de um vitral:

Compreendera que tudo aquilo era inapreensível: enganara-se ou subestimara o instante ao julgar que poderia guardá-lo. "Que este momento me possua, me ilumine e desapareça", pensava. "Eu o vivi. Eu o estou vivendo."

Sentia que a luz do sol a trespassava, como um vitral. (LINS: 1994, p. 83)

Novamente fazendo referência a Marinheiro de Primeira Viagem, livro que marcará o retorno de Osman Lins após sua experiência na Europa, Chartres e os vitrais ganham destaque no trecho que leva o nome da catedral: 


\section{Chartres}

"Maninha:

Poderia escrever, sendo conciso, quatro ou cinco páginas com os variados elementos da visita a Chartres. (...) Limito-me a dizer que, ao entrar na catedral, tive uma desilusão. Que, de súbito, descobrindo os vitrais do transepto, com suas grandes figuras solitárias, Aarão, David, parei extático. E que, alguns minutos depois, baixando os olhos, tive um sobressalto: as criaturas humanas pareceram-se chamas apagadas." (LINS: 1963, p. 40)

No que a crítica chamou de sua fase madura, ao compor Nove Novena, vitrais estão presentes no conto "Noivado" e em Avalovara, Osman Lins apresentará catedrais que abrigam os vitrais, povoando os espaços do livro, principalmente na narrativa A:

Ao sairmos, já os outros passageiros romperam esse contacto e é por cima do seu ombro que eu vejo, contra o céu estrelado, a torre em flecha da Sainte-Chapelle. Dezenas de pessoas seguem-nos, rápidas, entre as barracas dos vendedores de flores, haverá um concerto em Notre-Dame. A noite, depois das chuvas, lembra-se ladrilhos polidos e frascos transparentes. (LINS: 1973, p. 126)

Seja em sua literatura, seja em sua crítica encontramos catedrais e vitrais. Dentre seus ensaios, em Guerra sem testemunhas recolhemos as imagens, mesmo que usadas, por Osman Lins, como exemplificação de locais onde há o registro de seus artistas:

Construtores, na Idade Média, gravam seus nomes no piso das igrejas. No século XII, Surger, o reconstrutor de Saint-Denis, faz-se representar quatro vêzes na abadia e redige, em sua própria honra, nada menos de treze inscrições que faz gravar na pedra ou no metal, em diversos lugares do templo. Num dos vitrais, seu nome está inscrito em letras bem visíveis, idênticas que glorificam a virgem. (LINS: 1969, p. 67)

Em entrevista à Revista Escrita, em 1976, Osman Lins fala claramente sobre seu contato com os vitrais, as reflexões que estes suscitaram no escritor e seu desejo claro de transposição da técnica artística para sua literatura:

(...) [o vitral], sendo uma arte extremamente sintética, e até rústica, era uma arte altamente expressiva. (...) Então na minha literatura venho realmente buscando realizar uma obra que seja direta. Pode-se ter a impressão de que ela não é, mas no Avalovara, por exemplo, tudo é direto, muito nítido e luminoso, num certo sentido. (LINS: 1979, p. 212-213) 
Tais evidências atestam o interesse de Osman Lins pela arte presente nos vitrais e catedrais. Conseqüentemente, em seu Curso de História da Arte, o tema ganhará destaque, como mostrou-se até agora nesta aula sobre o gótico.

Osman Lins reconhece a tendência não realista da arte gótica, naquilo que ele chama de "admirável equilíbrio entre natureza e estilização", "simplicidade dos traços”, "concisão dos elementos", e a busca por uma solenidade e grandeza que não pertencem a este mundo, mas ao reino de Deus. Osman Lins, ele mesmo, assume, várias vezes, o objetivo não realista da sua literatura, como já vimos nas próprias aulas de Teoria Literária. Como no trecho já citado de Marinheiro de primeira viagem, nesta aula sobre o gótico, o autor oferece uma espécie de justificativa para o abandono relativo do puro figurativismo: "Diante desses vitrais, esquecemos por completo a natureza, qualquer exigência de semelhança, e mergulhamos inteiramente no reino da arte."

O modo como Osman Lins finaliza sua aula demonstra a perfeita consciência e domínio dos seus materiais e objetivos:

Cremos haver dado, tomando como exemplo a Catedral de Chartres, uma idéia bastante razoável da Arte Gótica. Vimos a igreja do exterior. Chegamos mesmo a vê-la do alto e nela penetramos. Notamos seus contrafortes, suas arcadas. Respiramos um pouco da sua atmosfera, deixamo-nos invadir pela solenidade dos seus interiores, vimos a luz de seus vitrais. Ao que já conhecemos da evolução das artes, mais uma noção definida e individualizada se acrescenta: o gótico.

\subsubsection{Renascimento Italiano}

Curiosamente, esta aula sobre o Renascimento não compartilha da mesma atmosfera de entusiasmo e alumbramento que existe nas aulas sobre o Românico e o Gótico. Mesmo com o risco de parecermos exagerados, é possível dizer que Osman Lins aborda esse período com certa secura, como se a harmonia, o equilíbrio e a perfeição das figuras o entediassem. Em vários momentos, o escritorprofessor apenas apresenta a imagem da obra, sem qualquer comentário. Às vezes, sua apreciação torna-se extremamente negativa: "Madonna della Candeletta, de Carlo Crivelli. Pinacoteca de Brera, em Milão: preocupação decorativa um tanto superficial”. 


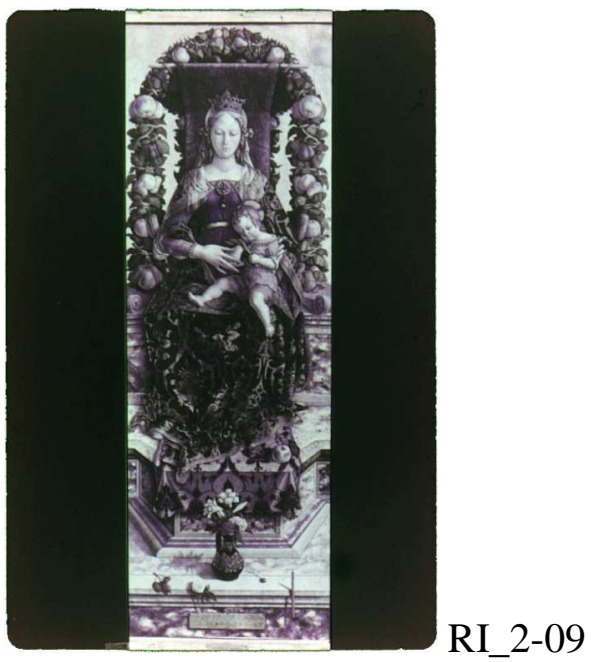

Evidentemente, no entanto, quando menciona os grandes mestres da época, como Michelangelo, Leonardo da Vinci e Rafael, Osman Lins não deixa de enfatizar sua grande qualidade.

De fato, podemos encontrar um suposta confirmação dessa suspeita na mesma entrevista de 1976, em que o autor revela claramente sua falta de simpatia pela arte renascentista:

(...) enquanto o Renascimento havia levado a uma visão perspectívica do mundo, naturalmente centrado no olho carnal humano, a Idade Média o levava a uma visão aperspectívica, devido ao fato exatamente de ser uma época não antropomórfica, uma época não antropocêntrica (...). Isso levava a uma visão do mundo muito mais rica, e não limitava a uma visão das coisas à condição carnal. (LINS: 1979, p. 212-213)137

E, mais adiante:

Um quadro de Rafael é realmente visto de uma perspectiva humana centralizada, ligada ao que há de perecível no olho humano. Enquanto que num quadro de Picasso, em sua fase cubista, por exemplo, nós vemos a cara do personagem de frente e esta mesma cara com um olho de lado. (...) Uma tentativa de romper com a condição mortal do olho humano, de ver através de um ponto de vista espiritual. O que se aproxima da visão do homem religioso da Idade Média. (LINS: 1979, p. 215)

Ao longo da aula Osman Lins acaba valorizando com maior intensidade obras que, por diferentes motivos fogem a uma configuração puramente clássica, seja pela incorporação de traços barrocos, seja pelo aproveitamento de elementos de períodos anteriores. Assim, a Pietá de Michelangelo, em que "toda a preocupação com a beleza plástica desaparece neste tronco nodoso, no qual, no movimento dos dois corpos paralelos, como escreve Michel Gallet, desafia o equilíbrio"; também em "A Ressurreição da Carne", de Signorelli, "quadro altamente estranho, com algo de 
selvagem". Por outro lado, o retorno a certas características medievais é destacado na obra de Filippo Lippi, Festa de Herodes: "segundo o hábito medieval, justapõe na mesma imagem dois episódios. Salomé à esquerda, obtém a cabeça de João. À direita, oferece-a a sua mãe", técnica que não deixa de lembrar um retábulo.

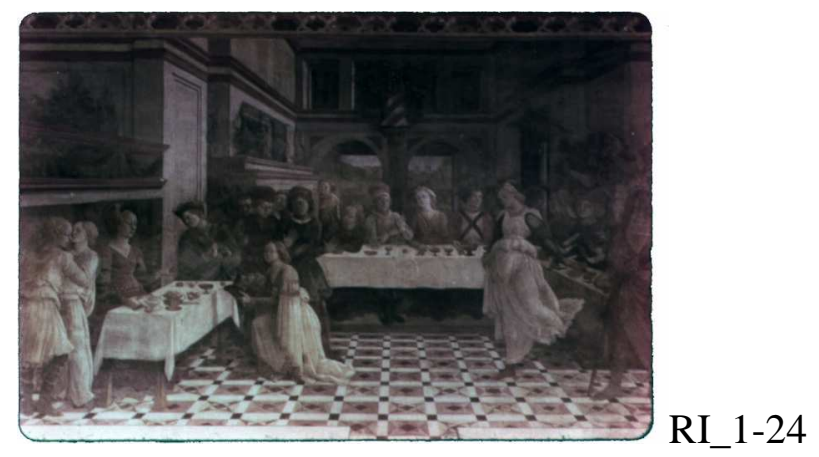

Verificamos que o que Osman Lins parece buscar nas obras de arte é a característica de transcendência. Sobre "A Virgem e o filho" de Baldovinetti, ele comenta: "indiscutível a beleza plástica", para depois acrescentar uma ressalva: "mas estamos longe da severidade e da transcendência que encontramos na arte religiosa das épocas gótica e românica”. Da mesma forma, sobre a Anunciação de Fra Angélico, observa: "sem perda da transcendência, muitas características do renascimento aí se encontram: a harmonia, a obsessão arquitetural, a atração pelo luxo".

Essa ênfase na transcendência também se manifesta na sua entrevista, quando define a sua posição como ficcionista:

(...) enquanto romancista, eu aspiro a uma visão cósmica. (...) O que eu procuro dar nos meus textos não é uma visão exclusiva do homem brasileiro, ou do Brasil, mas do cosmos. Eu sou um espírito voltado para o cosmos e a própria construção de Avalovara decorre disso. (LINS: 1979, p. 218)

A título de curiosidade, os painéis que compõem A Batalha de Uccello são novamente apresentados, posto que na aula sobre a Grécia, eles já foram usados: 


\begin{tabular}{|c|c|}
\hline Aula: Grécia clássica e helenística & Aula: Renascimento Italiano \\
\hline $\begin{array}{l}\text { Outro mosaico, representado a batalha de Isso, onde Dario é } \\
\text { vencido por Alexandre. Data do século II antes de Cristo. A } \\
\text { título de curiosidade, vale a pena compará-la com essa } \\
\text { batalha de Uccello, pintor florentino morto em } 1475 . \\
\text { Dezesseis séculos separam as duas obras, entre as quais se } \\
\text { nota, entretanto, grande semelhança de composição. }\end{array}$ & $\begin{array}{l}\text { (...) é principalmente através da pintura que o Renascimento } \\
\text { marcaria a arte no mundo. Batalha de São Romano, de } \\
\text { Paulo Uccello. Uccello pintou três painéis relativos a essa } \\
\text { batalha. }\end{array}$ \\
\hline
\end{tabular}




\section{Considerações finais}

"Para nós, há somente tentativa. O resto não é da nossa conta". T. S. Eliot 138

Ao assumir a cadeira de Literatura Brasileira, paralelamente às atividades exigidas de um professor universitário, Osman Lins dá continuidade à sua obra literária e desse período consolidam-se Avalovara (romance metalingüístico usado como projeto de pesquisa universitária), Lima Barreto e o espaço romanesco (fruto de sua dissertação de doutorado) e grande parte dos ensaios posteriormente publicados em Do ideal e da glória: problemas inculturais brasileiros. Seja em suas aulas, seja na sua obra, Osman Lins, ao mesmo tempo que reflete sobre seu próprio fazer literário, aponta para as dificuldades enfrentadas no ofício do escritor. Durante tal experiência como professor, emergem os problemas tanto no âmbito da educação superior no Brasil, quanto, de forma mais pontual, nas deficiências percebidas no ensino de Literatura. A dura realidade enfrentada no campo literário transpõe-se para o ambiente da universidade: ambos espaços carentes de apoio e estrutura para um pleno desenvolvimento cultural.

Diante desse desafio, o escritor assumiu o papel de professor e, com o mesmo empenho com que produziu seus livros, Osman Lins ministrou o Curso de Literatura Brasileira, buscando proporcionar aos estudantes, por meio de uma formação interdisciplinar, a oportunidade de desenvolverem seus próprios conhecimentos junto à arte literrária, e, à sua maneira, contaminá-los com sua fascinação por esta. Nesse intuito, lançou mão de outras artes: a dramática serviu como ferramenta didática na proposição de atividades em sala de aula e um curso extracurricular de História da Arte, com recursos audiovisuais, foi oferecido aos alunos. A reconstituição desse último permitiu a confirmação das preferências estéticas do escritor, que permearam sua produção escrita.

As análises dos cursos oferecidos pelo professor refletem a preocupação de um intelectual envolvido com a formação ampla de seus alunos ao mesmo tempo em que apresentam um escritor 
preocupado com seu ofício, a ponto de refletir sobre seu próprio trabalho, seja dentro da sala de aula, seja publicamente, por meio de suas obra literária ou seus ensaios.

Entre a dedicação exigida pela Literatura e os problemas enfrentados no magistério, o apaixonado escritor não hesita em escolher dedicar-se à arte da palavra escrita:

Esta necessidade de concentração contribuindo p/ decisão: afastar-me do ensino. ${ }^{139}$

Osman Lins opta pela Literatura, sem se deixar abater. O professor deixa a cena. Agora é o escritor que falará:

Entre realizar obra aquém de minhas possibilidades e fazer o melhor que me fosse possível, escolhi a última opção. (...)

Uma mente organizada nesses termos, voltada para as sínteses e para a contemplação, dificilmente poderia renunciar a isto, em favor de uma atividade [que já seria política]. Por outro lado, tenho uma noção das minhas forças e das forças que regem nossa sociedade - e sei bem que não teria possibilidade de mudar sensivelmente as coisas. Limito-me, então, a contemplar o mundo e meu povo, testemunhando sobre o nosso estar no mundo e permitindo que a compaixão xx e a cólera se introduzam, como um veneno ou um escorpião, nos meus escritos. ${ }^{140}$

139 Arquivo do Instituto de Estudos Brasileiros USP - Fundo Osman Lins. Código do documento: OL/MAG/Cx2/P2/28

140 Arquivo do Instituto de Estudos Brasileiros USP - Fundo Osman Lins. Código do documento: OL/MAG/Cx2/P2/06. Parte da presente citação também foi usada na nota 61. 


\section{Referências bibliográficas}

\section{Livros de Osman Lins:}

Guerra sem testemunhas: o escritor, sua condição e a realidade social. São Paulo: Martins Fontes, 1969.

Avalovara. São Paulo: Melhoramentos, 1973 (1ª edição).

Lima Barreto e o espaço romanesco. São Paulo: Ática, 1976.

Do ideal e da glória - problemas inculturais brasileiros. São Paulo: Summus, 1977.

Evangelho na Taba. Problemas inculturais brasileiros II, coletânea de artigos, ensaios e entrevistas, com apresentação de Julieta de Godoy Ladeira. São Paulo: Summus, 1979.

Os gestos. São Paulo: Moderna, 1994.

Nove, novena. São Paulo: Companhia das Letras, 1994. (4ª edição)

\section{Sobre Osman Lins:}

ALMEIDA, Hugo (org.). O sopro na argila. São Paulo: Nankin, 2004.

DIAS, Maria Teresa. Um teatro que conta: a dramaturgia de Osman Lins. 2004. 213 f. Tese (Doutorado em Teoria Literária e Literatura Comparada) - Faculdade de Filosofia, Letras e Ciências Humanas, Universidade de São Paulo. 2004.

FERREIRA, Ermelinda. A dama e o unicórnio: exercício de imaginação. In: Almeida, Hugo (org). $O$ sopro na argila. São Paulo: Nankin Editorial, 2004.

Cabeças Compostas: a personagem feminina na narrativa de Osman Lins.

São Paulo: Edusp, 2005.

FRITOLI, Luiz Ernani. Do ideal e da obra: visualidade e conformação do espaço literário em "Retábulo de Santa Joana Carolina”, de Osman Lins. 2004. 182 f. Dissertação (Mestrado em Teoria Literária e Literatura Comparada) - Faculdade de Filosofia, Letras e Ciências Humanas, Universidade de São Paulo. 2004. 
GARCIA, Wladimir. Osman Lins educador. Outra Travessia, Florianópolis, n. 4, p. 63-68, $1^{\text {o }}$ semestre de 2005.

HIGUCHI, Kazuko Kojima. Literatura, comunicação e educação - um romance em diálogo com a mídia. São Paulo: Cortez, 2008. (Coleção Aprender e Ensinar com Textos.)

IGEL, Regina. Osman Lins: uma biografia literária. São Paulo: T.A. Queiroz/INL, 1998.

RIBAS, Elisabete Marin et al. Marinheiros de Primeira Leitura. São Paulo: HUCITEC, 2004.

NITRINI, Sandra Margarida. Poéticas em confronto: Nove, Novena e o novo romance. São Paulo, Editora Hucitec; Brasília, Instituto Nacional do Livro, Fundação Nacional Pró-Memória/MINC, 1987.

NITRINI, Sandra Margarida. O tempo na arte, a arte no tempo (Uma leitura de Marinheiro de Primeira Viagem. In: ALMEIDA, Hugo. O sopro na argila. São Paulo: Nankin, 2004. p. 35-45. . Transfigurações: ensaios sobre a obra de Osman Lins. São Paulo:

Hucitec, 2010.

PEREIRA, Eder Rodrigues. A chave de Jano - os trajetos da criação de Avalovara de Osman Lins: uma leitura das notas de planejamento à luz da Crítica Genética. 2009. 309 f. Dissertação (Mestrado em Teoria Literária e Literatura Comparada) - Faculdade de Filosofia, Letras e Ciências Humanas, Universidade de São Paulo. 2009.

SOARES, Maria Balthasar. No arquivo do artesão. Revista Cult. São Paulo, n. 48, p. 62-63, julho 2001.

Aspectos do teatro de Osman Lins em Retábulo de Santa Joana Carolina.

2003. 113 f. Dissertação (Mestrado em Teoria Literária e Literatura Comparada), Faculdade de Filosofia, Letras e Ciências Humanas, Universidade de São Paulo. 2003.

\section{Demais referências:}

ALENCAR, José de. Como e porque sou romancista. Rio de Janeiro: Leuzinger \& Filhos, 1893. BOSI, Alfredo. Reflexões sobre a arte. São Paulo: Ática, 1986.

DA VINCI, Leonardo. Tratado de Pintura. Madrid: Editora Nacional, 1980. 
FOUCAULT, Michel. As palavras e as coisas: uma arqueologia das ciências humanas. São Paulo: Martins Fontes, 1999.

GOMBRICH, E. H. A História da Arte. Rio de Janeiro: LTC, 1993.

* KAYSER, Wolfgang. O Grotesco: configuração na pintura e na Literatura. São Paulo: Perspectiva, s.d.

LESSING, Gothhold Efraim. Laocoonte ou sobre as fronteiras da Pintura e da Poesia. São Paulo: Iluminuras, 1998.

MOTA, Carlos Guilherme. Ideologia da Cultura Brasileira (1933-1974). São Paulo: Editora 34, 2008.

ORTIZ, Renato. Sociedade e Cultura. In: PINHEIRO, Paulo Sérgio (org.). Brasil: um século de transformações. São Paulo: Companhia das Letras, 2001, p. 184-209.

PRAZ, Mário. Literatura e Artes Visuais. São Paulo: Cultrix, 1982.

SCHØLLHAMMER, Karl Erik. Além do visível: o olhar da Literatura. Rio de Janeiro: 7 Letras, 2007.

* TODOROV, Tzvetan. As estruturas narrativas. São Paulo: Perspectiva, 2006.

*. Livros citados por Osman Lins durante seu Curso de Literatura Brasileira.

\section{Bibliografia Consultada:}

ARISTÓTELES. Poética. São Paulo: Abril Cultural, 1973. Coleção “Os Pensadores”.

BAUMGART, Fritz. Breve História da Arte. São Paulo: Martins Fontes, 2007.

BOSI, Alfredo. Plural, mas não caótico. In: Cultura brasileira. São Paulo, Ática, 1987.

LEITE, Ligia Chiappini Moraes. A invasão da catedral: Literatura e ensino em debate. Porto Alegre: Mercado Aberto, 1988.

. Reinvenção da catedral: língua, literatura, comunicação, novas tecnologias, políticas de ensino. São Paulo: Cortez: 2005.

DEWEY, John. A arte como experiência. In: Os pensadores. São Paulo: Abril, 1974, 1a edição.

FILHO, Domício Proença. A linguagem literária. São Paulo: Ática, 1992. 
JANSON, H. W e JANSON, ANTHONY. Iniciação à história da arte. São Paulo: Martins Fontes, 1996. História geral da arte. São Paulo: Martins Fontes, 2001.

LUKÁCS, George. Narrar ou descrever. In: Ensaios sobre Literatura. Rio de Janeiro: Civilização Brasileira, 1965.

MANGUEL, Alberto. Uma história da leitura. São Paulo: Companhia das Letras, 1997. . Lendo imagens. São Paulo: Companhia das Letras, 2001.

PINHEIRO, Paulo Sérgio (org.). Brasil: um século de transformações. São Paulo: Companhia das Letras, 2001, p.200.

SAMOYAULT, Tiphaine. A intertextualidade. São Paulo: Hucitec, 2008.

SOARES, Maria Balthasar. Tempo de Avalovara: as diferentes dimensões temporais no Romance de Osman Lins. 2007. 160 f. Tese (Doutorado em Teoria Literária e Literatura Comparada) Faculdade de Filosofia, Letras e Ciências Humanas, Universidade de São Paulo. 2007.

STEEN, Edla van. Viver \& Escrever. Porto Alegre: L\&PM, 1981.

WELLEK, René. WARREN, Austin. Teoria da literatura e metodologia dos estudos literários. São Paulo: Martins Fontes, 2003.

WOLFFLIN, Heinrich. Conceitos fundamentais da história da arte. São Paulo: Martins Fontes, 2000.

\section{Sites:}

www.ieb.usp.br/catalogo_eletronico

www.osman.lins.nom.br 


\section{Anexos}

\section{ANEXO 1}

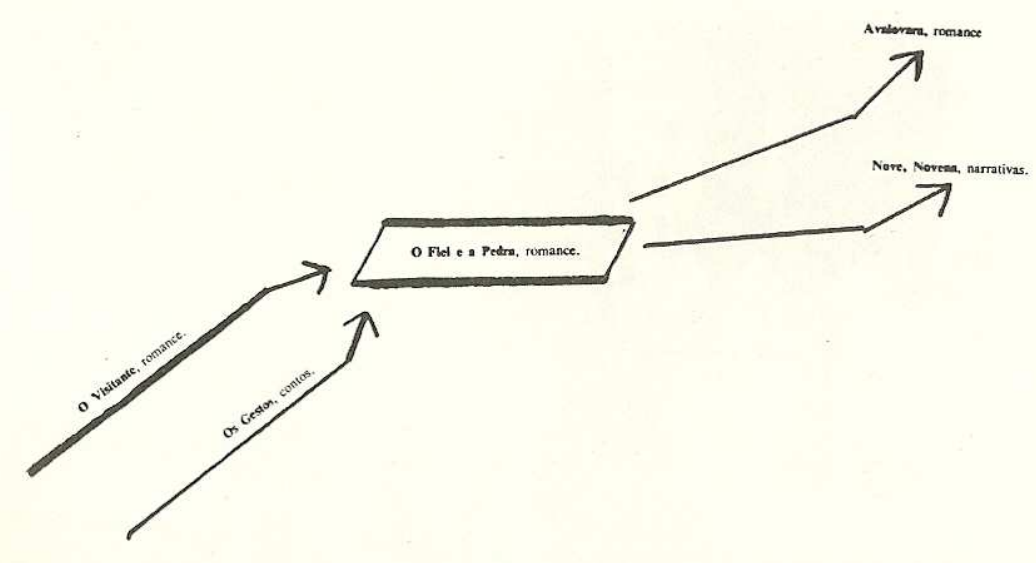

Gráfico em que o autor situa o romance $O$ fiel e a pedra em sua obra.

IGEL, Regina. Osman Lins: uma biografia literária. São Paulo: T.A. Queiroz/INL, 1998, p. 57. 


\section{ANEXO 2}

\section{IEB - Instituto de Estudos Brasileiros \\ Fundo Osman Lins}

Fitas gravadas convertida para MP3

\begin{tabular}{|l|l|l|}
\hline Fita 1 & Data da gravação & Tempo \\
\hline A - Fala da mãe.mp3 & $13 / 06 / 2005$ & $3 \mathrm{~min} 57 \mathrm{seg}$ \\
\hline A - Procissão - Viagem a & $16 / 05 / 2005$ & $48 \mathrm{~min} 38 \mathrm{seg}$ \\
\hline B. mp3 & & \\
\hline Fita 2 & $16 / 05 / 2005$ & $44 \mathrm{~min} 34 \mathrm{seg}$ \\
\hline A - Aula de pintura1.mp3 & $16 / 05 / 2005$ & Tempo \\
\hline B - Grécia - Class. e & Data da gravação & $42 \mathrm{~min} 06 \mathrm{seg}$ \\
\hline Helenismo.mp3 & $16 / 05 / 2005$ & $38 \mathrm{~min} 51 \mathrm{seg}$ \\
\hline Fita 3 & & \\
\hline A - Arte Bizâncio - & & $31 \mathrm{~min} 01 \mathrm{seg}$ \\
\hline Românico.mp3 & Data da gravação & Tempo \\
\hline B - Pintura Românico.mp3 & $19 / 05 / 2005$ & $30 \mathrm{~min} 55 \mathrm{seg}$ \\
\hline Fita 4 & Data da gravação & Tempo \\
\hline A - Gótico.mp3 & $19 / 05 / 2005$ & \\
\hline B - Renascimento italiano.mp3 & $19 / 05 / 2005$ & Tempo \\
\hline Fita 5 & Data da gravação & $3 \mathrm{~min} 24 \mathrm{seg}$ \\
\hline A.mp3 & $19 / 05 / 2005$ & \\
\hline & & \\
\hline
\end{tabular}




\begin{tabular}{|l|l|l|}
\hline B - M. Luponge Tradutora $p$ & $19 / 05 / 2005$ & $30 \mathrm{~min} 49 \mathrm{seg}$ \\
\hline Franceses.mp3 & & \\
\hline A - Audiovisual O. Lins.mp3 & $06 / 06 / 2005$ & $28 \mathrm{~min} 23 \mathrm{seg}$ \\
\hline B.mp3 & $06 / 06 / 2005$ & $1 \mathrm{~min} 21 \mathrm{seg}$ \\
\hline Fita 7 & Data da gravação & Tempo \\
\hline A - Caso Especial.mp3 & $06 / 06 / 2005$ & $30 \mathrm{~min} 43 \mathrm{seg}$ \\
\hline B.mp3 & $06 / 06 / 2005$ & $23 \mathrm{~min} 24 \mathrm{seg}$ \\
\hline Fita 8 & Data da gravação & Tempo \\
\hline A - Aracaju 1976 - & $09 / 06 / 2005$ & $30 \mathrm{~min} 33 \mathrm{seg}$ \\
\hline Avalovara.mp3 & & \\
\hline B.mp3 & & $29 \mathrm{~min} 33 \mathrm{seg}$ \\
\hline Fita 9 & Data da gravação & Tempo \\
\hline A - Conversa com mamãe.mp3 & $13 / 06 / 2005$ & \\
\hline B.mp3 & $13 / 06 / 2005$ & \\
\hline
\end{tabular}




\section{ANEXO 3}

Trecho da CRONOLOGIA ESTRATIFICADA, com recorte temporal selecionando o período em que Osman Lins atuou como professor.

Os eventos são registrados a partir de documentação presente no Fundo Osman Lins - Arquivo IEB-USP:

\begin{tabular}{|c|c|c|c|c|c|c|c|}
\hline $\begin{array}{l}\mathbf{A} \\
\mathbf{N} \\
\mathbf{O}\end{array}$ & $\frac{\text { IDENTIDADE }}{\underline{\text { CIVIL }}}$ & $\begin{array}{l}\text { VIDA DOMÉSTICA E } \\
\text { FAMILIAR }\end{array}$ & RELACÕESS SOCIAIS & FORMAC̄̃̃O & $\begin{array}{l}\text { CARREIRA } \\
\text { BANCÁRIA }\end{array}$ & MAGISTÉRIO & LITERATURA \\
\hline $\begin{array}{l}1 \\
9 \\
7 \\
0\end{array}$ & & & & & $\begin{array}{l}\text {-Pedido de licença de três } \\
\text { meses para ingressar na } \\
\text { Faculdade de Marília. }\end{array}$ & $\begin{array}{l}\text {-Ingresso na Faculdade de } \\
\text { Filosofia de Marília, } \\
\text { cátedra de Literatura } \\
\text { Brasileira (onde atua até } \\
\text { 1976). } \\
\text { - Apresentação do Plano } \\
\text { de Pesquisa, escolhendo } \\
\text { como orientador o } \\
\text { professor Antonio } \\
\text { Candido. A pesquisa } \\
\text { referia-se a composição do } \\
\text { romance Avalovara. } \\
\text { - Acompanhamentos } \\
\text { acadêmicos: apresentação } \\
\text { anual de relatórios com os } \\
\text { programas desenvolvidos } \\
\text { na cadeira de Literatura } \\
\text { Brasileira. }\end{array}$ & 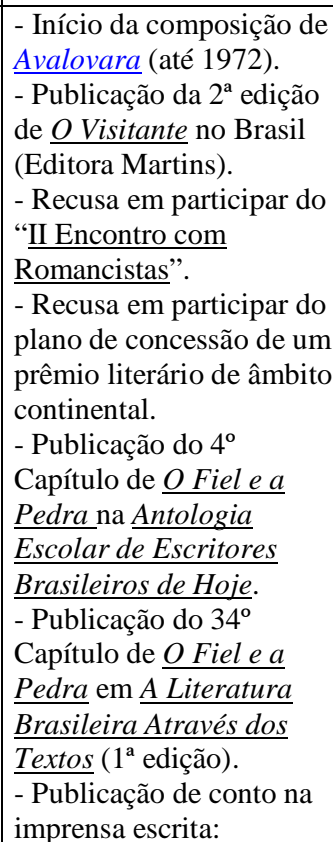 \\
\hline
\end{tabular}




\begin{tabular}{|c|c|c|c|c|c|c|c|}
\hline $\begin{array}{l}\mathbf{A} \\
\mathbf{N} \\
\mathbf{O}\end{array}$ & $\frac{\text { IDENTIDADE }}{\underline{\text { CIVIL }}}$ & $\begin{array}{l}\text { VIDA DOMÉSTICA E } \\
\text { FAMILIAR }\end{array}$ & $\underline{\text { RELACCÕES SOCIAIS }}$ & FORMACC̃̃O & $\begin{array}{l}\text { CARREIRA } \\
\text { BANCÁRIA }\end{array}$ & MAGISTÉRIO & $\underline{\text { LITERATURA }}$ \\
\hline & & & & & & & $\begin{array}{l}\text { "Ventosa, o chofer". } \\
\text { - Tradução de } O \text { Visitante } \\
\text { para o francês, realizada } \\
\text { por Pierre Carré. }\end{array}$ \\
\hline \begin{tabular}{l|}
1 \\
9 \\
7 \\
1
\end{tabular} & & $\begin{array}{l}\text { - Terceira viagem à } \\
\text { Europa, em companhia de } \\
\text { Julieta e Letícia (Janeiro). }\end{array}$ & & & $\begin{array}{l}\text { - Participação no } \\
\text { "Sindicato dos } \\
\text { Empregados em } \\
\text { Estabelecimentos } \\
\text { Bancários" de São Paulo. } \\
\text { - Aposentadoria. }\end{array}$ & $\begin{array}{l}\text { - Renovação de contrato } \\
\text { em período integral com a } \\
\text { Universidade de Marília. } \\
\text { - Programa, planos de } \\
\text { cursos e artigos publicados } \\
\text { durante as atividades } \\
\text { acadêmicas. }\end{array}$ & 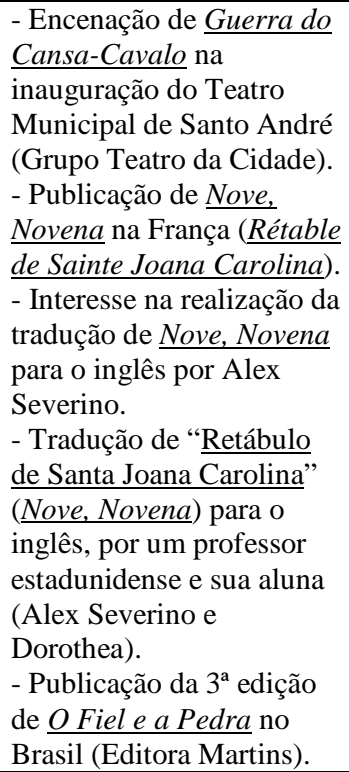 \\
\hline $\begin{array}{l}1 \\
9 \\
7 \\
2\end{array}$ & & $\begin{array}{l}\text { - Morte do pai de Julieta } \\
\text { de Godoy Ladeira, sogro } \\
\text { de Osman Lins (Março). }\end{array}$ & & & & $\begin{array}{l}\text { - Planos de aulas para } \\
\text { atender às mudanças } \\
\text { curriculares do curso de } \\
\text { Letras. }\end{array}$ & $\begin{array}{l}\text { - Publicação de "O Pássaro } \\
\text { Transparente" (Nove, } \\
\text { Novena) nos EUA ("The } \\
\text { Transparent Bird", } \\
\text { International Anthology of } \\
\text { Prose). } \\
\text { - Tradução de "Retábulo } \\
\text { de Santa Joana Carolina" } \\
\text { (Nove, Novena) para o } \\
\text { alemão, por Marianne } \\
\text { Jolowicz. }\end{array}$ \\
\hline $\begin{array}{l}1 \\
9 \\
7 \\
3\end{array}$ & & $\begin{array}{l}\text { - Quarta viagem à Europa } \\
\text { para contato com editores. }\end{array}$ & & $\begin{array}{l}\text { - Defesa da tese de } \\
\text { doutorado } \\
\text { Lima Barreto e o Espaço } \\
\text { Romanesco } \\
\text { (USP) }\end{array}$ & & & $\begin{array}{l}\text { - Publicação da } 1^{\text {a }} \text { edição } \\
\text { de Avalovara no Brasil } \\
\text { (Editora Melhoramentos). } \\
\text { - Publicação de "Elegíada" } \\
\text { (Os gestos) na França }\end{array}$ \\
\hline
\end{tabular}




\begin{tabular}{|c|c|c|c|c|c|c|c|}
\hline $\begin{array}{l}\mathbf{A} \\
\mathbf{N} \\
\mathbf{O}\end{array}$ & $\frac{\underline{\text { IDENTIDADE }}}{\underline{\text { CIVIL }}}$ & $\begin{array}{l}\text { VIDA DOMÉSTICA E } \\
\text { FAMILIAR }\end{array}$ & RELACÕ̃ES SOCIAIS & FORMACÃ̃O & $\begin{array}{l}\text { CARREIRA } \\
\text { BANCÁRIA }\end{array}$ & MAGISTÉRIO & LITERATURA \\
\hline & & & & & & & 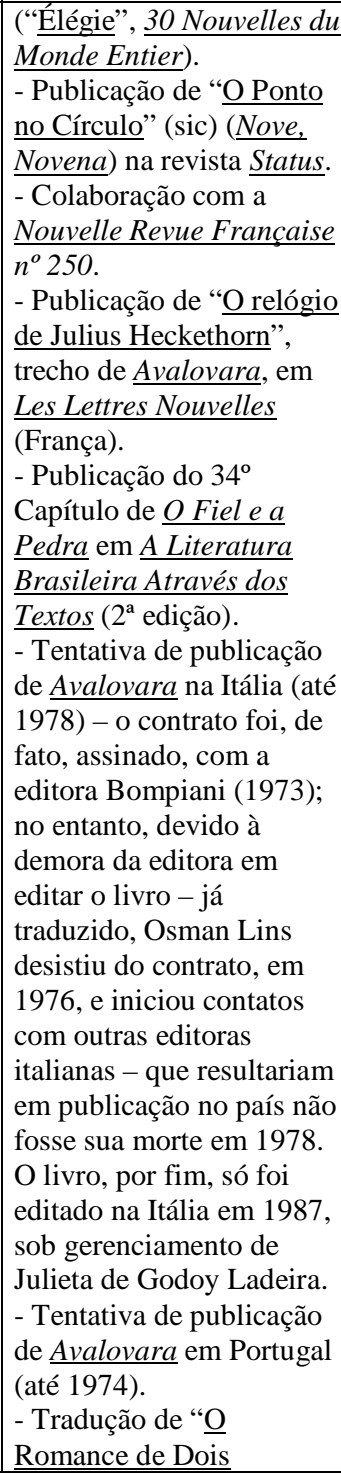 \\
\hline
\end{tabular}




\begin{tabular}{|c|c|c|c|c|c|c|c|}
\hline $\begin{array}{l}\mathbf{A} \\
\mathbf{N} \\
\mathbf{O}\end{array}$ & $\frac{\text { IDENTIDADE }}{\text { CIVIL }}$ & $\begin{array}{l}\text { VIDA DOMÉSTICA E } \\
\text { FAMILIAR }\end{array}$ & $\underline{\text { RELACÕ̃ES SOCIAIS }}$ & FORMACC̃̃O & $\begin{array}{l}\text { CARREIRA } \\
\text { BANCÁRIA }\end{array}$ & MAGISTÉRIO & $\underline{\text { LITERATURA }}$ \\
\hline & & & & & & & $\begin{array}{l}\text { Soldados de Herodes" para } \\
\text { o francês, por Pierre Carré. }\end{array}$ \\
\hline $\begin{array}{l}1 \\
9 \\
7 \\
4\end{array}$ & & $\begin{array}{l}\text { - Morte do tio Antônio } \\
\text { Bento Figueiredo, } \\
\text { inspiração para o herói } \\
\text { Bernardo de } O \text { Fiel e a } \\
\text { Pedra (Julho). } \\
\text { - Quinta viagem à Europa } \\
\text { para contato com editores } \\
\text { (especialmente italianos) - } \\
\text { Janeiro. }\end{array}$ & & $\begin{array}{l}\text { - Obtenção do título de } \\
\text { Doutor em Letras pela } \\
\text { Faculdade de Filosofia, } \\
\text { Ciências e Letras de } \\
\text { Marília. }\end{array}$ & & $\begin{array}{l}\text { - Início do estágio na } \\
\text { Universidade de São } \\
\text { Paulo, junto ao } \\
\text { departamento de Letras } \\
\text { Clássicas e Vernáculas, } \\
\text { onde estagiará até } 1975 . \\
\text { - Convites para a } \\
\text { participação em bancas e } \\
\text { atividades acadêmicas. } \\
\text { - Convite para compor o } \\
\text { corpo docente do curso de } \\
\text { Pós-Graduação da } \\
\text { Universidade de Marília. } \\
\text { - Encenação de Mistério } \\
\text { das Figuras de Barro } \\
\text { pelos alunos de Marília, } \\
\text { sob a direção do autor. } \\
\text { - Concessão de voto de } \\
\text { louvor pela apresentação } \\
\text { da peça Mistério das } \\
\text { Figuras de Barro, na } \\
\text { semana comemorativa do } \\
\text { XV aniversário da } \\
\text { Universidade de Marília. } \\
\text { - Início do processo do } \\
\text { pedido de afastamento, } \\
\text { que desencadeará no } \\
\text { desligamento da } \\
\text { Universidade de Marília. }\end{array}$ & 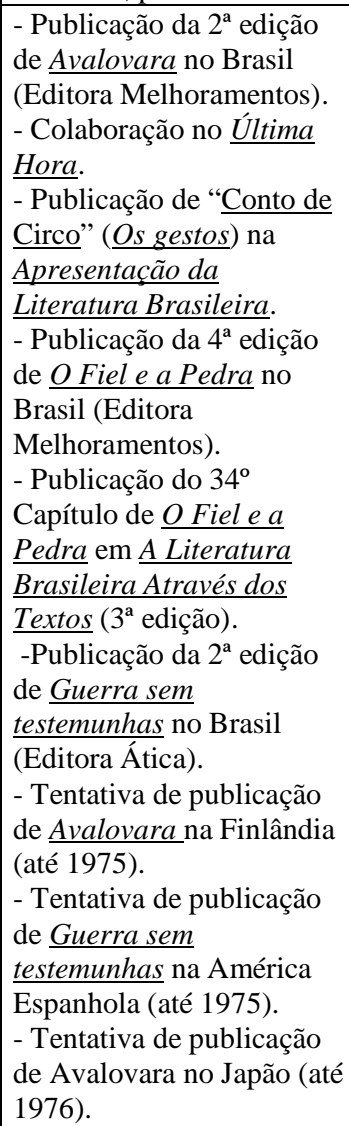 \\
\hline $\begin{array}{l}1 \\
9 \\
7 \\
5\end{array}$ & $\begin{array}{l}\text { - perda e reemissão de } \\
\text { documentos pessoais. }\end{array}$ & $\begin{array}{l}\text { - Casamento da filha: } \\
\text { Litânia (23/12). } \\
\text { - Sexta viagem à Europa } \\
\text { (para o lançamento da } \\
\text { edição francesa de } \\
\text { Avalovara). }\end{array}$ & & & & & $\begin{array}{l}\text { - Publicação da } 3^{\text {a }} \text { edição } \\
\text { de Avalovara no Brasil } \\
\text { (Editora Melhoramentos). } \\
\text { - Publicação da trilogia de } \\
\text { peças Santa, Automóvel e } \\
\text { Soldado no Brasil (Editora } \\
\text { Duas Cidades). } \\
\text { - Adaptação de "A Ilha no }\end{array}$ \\
\hline
\end{tabular}




\begin{tabular}{|c|c|c|c|c|c|c|}
\hline \begin{tabular}{c|c} 
A & IDENTIDADE \\
$\mathbf{N}$ & $\underline{\text { CIVIL }}$ \\
$\mathbf{0}$ &
\end{tabular} & $\begin{array}{l}\text { VIDA DOMÉSTICA E } \\
\text { FAMILIAR }\end{array}$ & RELACÕ̃ES SOCIAIS & $\underline{\text { FORMACC̃̃OO }}$ & $\begin{array}{l}\text { CARREIRA } \\
\text { BANCÁRIA }\end{array}$ & MAGISTÉRIO & LITERATURA \\
\hline & & & & & & 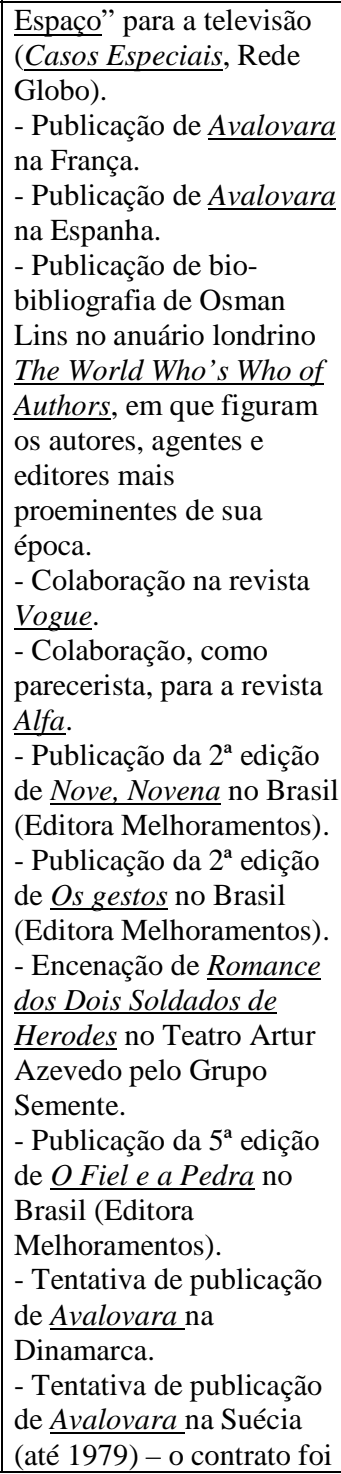 \\
\hline
\end{tabular}




\begin{tabular}{|c|c|c|c|c|c|c|c|}
\hline $\begin{array}{l}\mathbf{A} \\
\mathbf{N} \\
\mathbf{O}\end{array}$ & $\frac{\text { IDENTIDADE }}{\underline{\text { CIVIL }}}$ & $\begin{array}{l}\text { VIDA DOMÉSTICA E } \\
\text { FAMILIAR }\end{array}$ & RELACÕES SOCIAIS & FORMACC̃̃O & $\begin{array}{l}\text { CARREIRA } \\
\text { BANCÁRIA }\end{array}$ & MAGISTÉRIO & LITERATURA \\
\hline & & & & & & & $\begin{array}{l}\text { assinado em } 1976 \text { com a } \\
\text { editora Forum, mas a } \\
\text { publicação não foi } \\
\text { efetuada, apesar de Julieta } \\
\text { de Godoy Ladeira ter } \\
\text { continuado a tentativa } \\
\text { junto à editora sueca após } \\
\text { a morte do autor. } \\
\text { - Tentativa de publicação } \\
\text { de Avalovara na Holanda } \\
\text { (até 1976). } \\
\text { - Tentativa de publicação } \\
\text { de Avalovara na Noruega } \\
\text { (até 1976). } \\
\text { - Tentativa de publicação } \\
\text { de Avalovara na } \\
\text { Tchecoslováquia (até } \\
\text { 1977). } \\
\text { - Tentativa de publicação } \\
\text { de } O \text { Fiel e a Pedra na } \\
\text { URSS. }\end{array}$ \\
\hline $\begin{array}{l}1 \\
9 \\
7 \\
6\end{array}$ & & $\begin{array}{l}\text { - Sétima viagem à Europa } \\
\text { (Feira de Frankfurt) - } \\
\text { Setembro. }\end{array}$ & & & & $\begin{array}{l}\text { - Desligamento da cátedra } \\
\text { de Literatura Brasileira na } \\
\text { Universidade de Marília. }\end{array}$ & $\begin{array}{l}\text { - Publicação de A Rainha } \\
\text { dos Cárceres da Grécia no } \\
\text { Brasil (Editora } \\
\text { Melhoramentos). } \\
\text { - Publicação na imprensa } \\
\text { escrita de artigo crítico ao } \\
\text { ensino de letras no Brasil. } \\
\text { - Adaptação de "Quem era } \\
\text { Shirley Temple?" para a } \\
\text { televisão (Casos } \\
\text { Especiais, Rede Globo). } \\
\text { - Publicação de Avalovara } \\
\text { na Alemanha. } \\
\text { - Colaboraçãao para o } \\
\text { Jornal do Brasil (até } \\
\text { 1978). } \\
\text { - Colaboração no Jornal } \\
\text { da Tarde (até 1977). } \\
\text { - Publicação de "Pastoral" } \\
\text { (Nove, Novena) em Contos } \\
\text { Escolhidos. }\end{array}$ \\
\hline
\end{tabular}




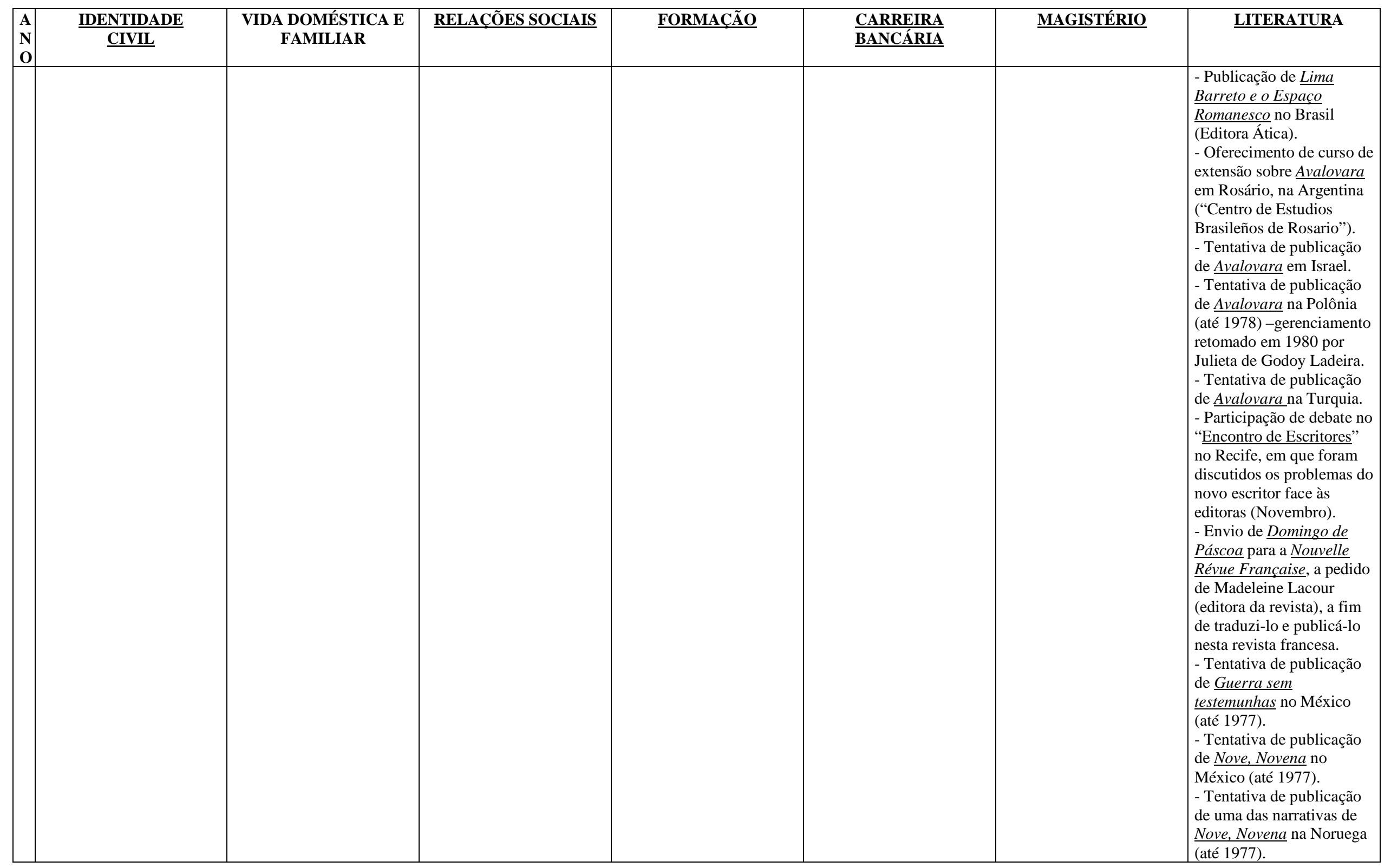




\begin{tabular}{|c|c|c|c|c|c|c|}
\hline \begin{tabular}{c|c}
$\mathbf{A}$ & IDENTIDADE \\
$\mathbf{N}$ & $\underline{\text { CIVIL }}$ \\
$\mathbf{0}$ &
\end{tabular} & $\begin{array}{l}\text { VIDA DOMÉSTICA E } \\
\text { FAMILIAR }\end{array}$ & RELACÕ̃ES SOCIAIS & $\underline{\text { FORMACC̃̃OO }}$ & $\begin{array}{l}\text { CARREIRA } \\
\text { BANCÁRIA }\end{array}$ & MAGISTÉRIO & LITERATURA \\
\hline & & & & & & 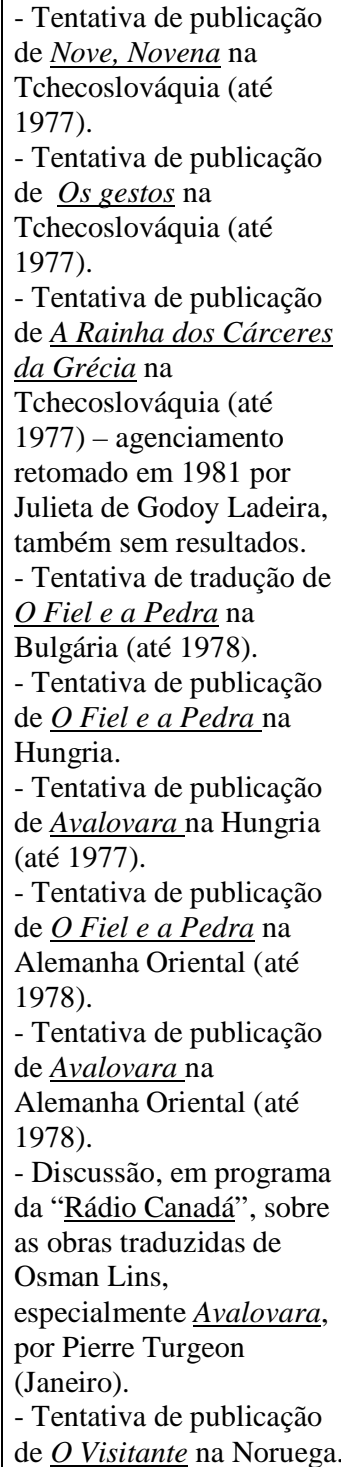 \\
\hline
\end{tabular}




\begin{tabular}{|c|c|c|c|c|c|c|c|}
\hline $\begin{array}{l}\mathbf{A} \\
\mathbf{N} \\
\mathbf{O}\end{array}$ & $\frac{\underline{\text { IDENTIDADE }}}{\underline{\text { CIVIL }}}$ & $\begin{array}{l}\text { VIDA DOMÉSTICA E } \\
\text { FAMILIAR }\end{array}$ & RELACÕ̃ES SOCIAIS & FORMAČ̃̃O & $\begin{array}{l}\text { CARREIRA } \\
\text { BANCÁRIA }\end{array}$ & MAGISTÉRIO & LITERATURA \\
\hline \begin{tabular}{l|}
1 \\
9 \\
7 \\
7
\end{tabular} & & $\begin{array}{l}\text { - Viagem ao Peru e à } \\
\text { Bolívia com } \\
\text { Julieta de Godoy Ladeira } \\
\text { - Falecimento da tia } \\
\text { paterna Laura. } \\
-13^{\circ} \text {. aniversário de } \\
\text { casamento com Julieta. } \\
\text { - Intervenção cirúrgica } \\
\text { (Março). }\end{array}$ & $\begin{array}{l}\text { - Defesa dos direitos } \\
\text { autorais de Oswaldo } \\
\text { Louzada. }\end{array}$ & $\begin{array}{l}\text { - Utilização, para retirada } \\
\text { de livros, da biblioteca do } \\
\text { "Instituto Goethe São } \\
\text { Paulo - Centro Cultural } \\
\text { Brasil-Alemanha". }\end{array}$ & & & 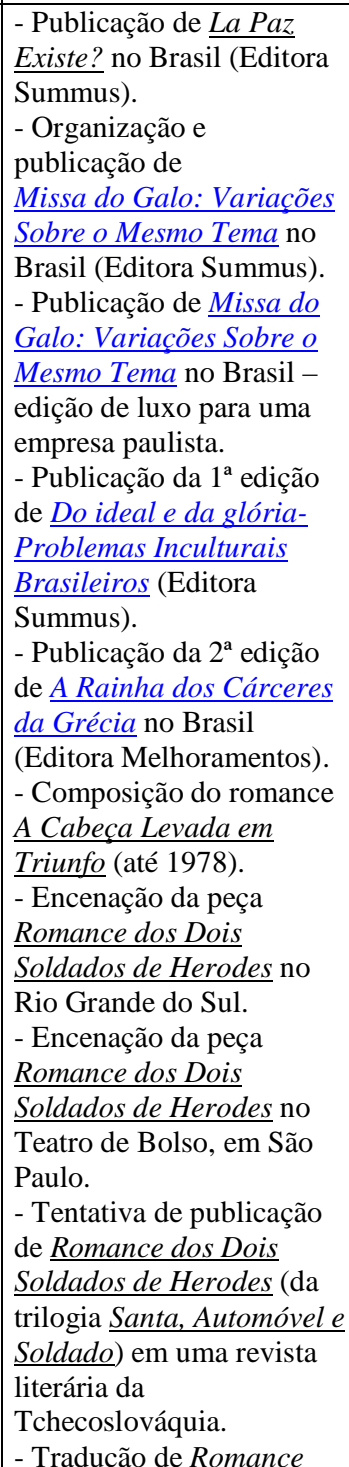 \\
\hline
\end{tabular}




\begin{tabular}{|c|c|c|c|c|c|c|c|}
\hline $\begin{array}{c}\mathbf{A} \\
\mathbf{N} \\
\mathbf{O}\end{array}$ & $\frac{\text { IDENTIDADE }}{\text { CIVIL }}$ & $\begin{array}{l}\text { VIDA DOMÉSTICA E } \\
\text { FAMILIAR }\end{array}$ & RELACÕ̃ES SOCIAIS & $\underline{\text { FORMACCÃOO }}$ & $\begin{array}{l}\text { CARREIRA } \\
\text { BANCÁRIA }\end{array}$ & MAGISTÉRIO & LITERATURA \\
\hline & & & & & & & 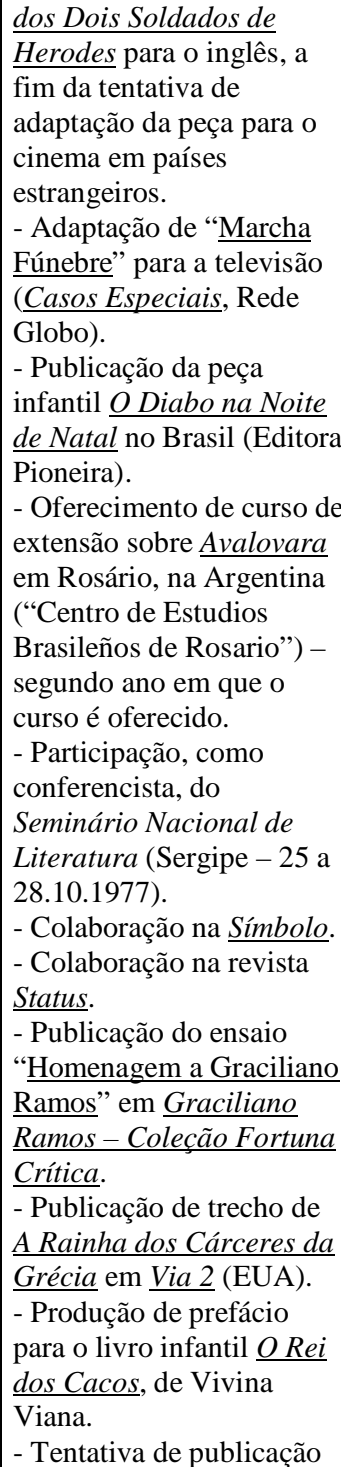 \\
\hline
\end{tabular}




\begin{tabular}{|c|c|c|c|c|c|c|c|}
\hline $\begin{array}{l}\mathbf{A} \\
\mathbf{N} \\
\mathbf{O}\end{array}$ & $\frac{\text { IDENTIDADE }}{\underline{\text { CIVIL }}}$ & $\begin{array}{l}\text { VIDA DOMÉSTICA E } \\
\text { FAMILIAR }\end{array}$ & RELACÕES SOCIAIS & FORMAČ̃̃O & $\begin{array}{l}\text { CARREIRA } \\
\text { BANCÁRIA }\end{array}$ & MAGISTÉRIO & LITERATURA \\
\hline & & & & & & & 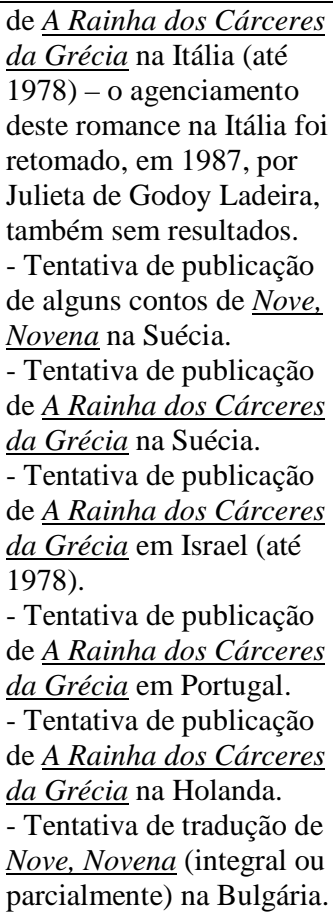 \\
\hline
\end{tabular}




\section{ANEXO 4}

\section{Apólogo do Herói bem conduzido}

Osman Lins

Puseram-me, quando nasci, o nome de Artaxerxes. Até aí, nada mais, pois eu ainda não sabia falar. Já não estou muito de acordo com a troca que foi feita anos depois, à altura dos sete ou oito anos. Perguntaram-me:

- Como se chama?

- Artaxerxes.

- Não. Disseram-me. Agora você se chama João. É melhor, mais cômodo e será mais vantajoso. Pensamos sempre no nosso querido João.

Eu já estava na escola. Não a que eu desejava cursar, num prédio antigo, de paredes amarelas, com um gramado na frente, mas outra, perto do cemitério, com professores vindos do estrangeiro, atenciosos, cheios de sabedoria, mas incapazes de entender o meu Português. Eu preferia ir à aula de manhã e ficar livre à tarde. Por coincidência, assim foi feito: eu ia à escola às oito e voltava ao meiodia, passando a tarde na brincadeira, mas não por ser assim que eu ambicionava, pois não fui consultado. Eis porque, vez por outra, eu me perguntava se não seria melhor o contrário, folga pela manhã e aula de tarde. E se o regime escolhido não tinha em vista os interesses de alguma outra pessoa, não os meus.

Quanto à alimentação, nem uma só vez, em toda a vida, procuraram saber do que eu gostava. Café da manhã, almoço, jantar, tudo era bem preparado e sempre vinha à hora certa. Nunca, entretanto, tive oportunidade de dizer o que desejava ter à mesa. Sabia que devia comer e comia. Mas nunca tive fome, nunca. E acho que o homem, às vezes, tem o direito de jejuar.

No que se refere aos brinquedos e roupas, seria injusto queixar-me. Jamais tive frio e os brinquedos eram periodicamente substituídos, de acordo com minha idade. Houve até alguns os quais me afeiçoei. Não pude conservá-los. Eram tirados de mim no momento oportuno. Naturalmente sem consulta prévia.

Não se pense que os cuidados comigo foram apenas nessas coisas. Eu tinha (e ainda tenho) de pentear o cabelo segundo um molde aprovado sem meu voto; meu modo de falar prejudicava-me, tive de seguir aulas de dicção; andava com as pontas dos pés meio afastadas, fui obrigado a endireitá-las; sentava-me derreado, isto também foi corrigido; dormia de borco e tanto apanhei que me submeti, resignado, à posição correta. 
Alguns dos meus companheiros liam obras pornográficas ou de aventuras. Eu não escolhia o que ler: os livros eram postos em minha cabeceira, histórias de porquinhos, de coelhinhos, de fadas, de princesas de burrinhos filosóficos, de abelhinhas, depois de bons meninos com bons pais, boas mães, boas irmãs, depois de homens honestos, depois de vultos da História Universal, nenhum dos quais urinava.

Concluídos os preparatórios foi estabelecido que eu seria um homem útil e correto. Foi quando me perguntaram:

- João, você quer ser o que?

Eu disse:

- O que vocês quiserem.

E eles:

- Ótimo, excelente. Maravilhoso. Você vai ser um homem útil e correto.

Fiz o vestibular e entrei na Faculdade Integrada de Homens úteis e Corretos. O currículo era amplo e eu, aí, podia escolher, por exemplo, entre Introdução à Obediência ou Prolegômenos do Consentimento Tácito. Ou entre Sistemática da Resignação ou Estilística da Concordância Absoluta. Ou ainda, entre História Universal da Decência ou Filosofia da Honestidade.

Estudávamos em apostilas, as quais tinham vantagem de expurgar, dos livros, os trechos impróprios, incovenientes, cansativos, preparatórios ou dispensáveis, atendo-se ao essencial - ao que caía nos exames. Éramos todos ótimos alunos, cuidadosos, pontuais, servis, jamais questionávamos os programas, venerávamos os professores e sempre estávamos de acordo com tudo que a Direção resolvia. Sempre conversávamos sobre as matérias estudadas e só nos espantava (mesmo assim, não muito) o fato de serem quase idênticas - na verdade, iguais - as apostilas, por exemplo, de Prolegômenos do Consentimento e de Introdução à Obediência. Mas isso nunca chegou a inquietarnos.

Mas saí da faculdade, vi que existia toda uma legislação à minha espera, pronta para guiar-me os passos, proteger-me e evitar que me sobreviesse algum infortúnio. Eu tinha a idéia, é certo que um tanto vaga, de fixar-me no litoral; mas fui enviado para o Oeste, o que foi - confesso - uma surpresa, pois eu nunca pensara que nosso país tivesse Oeste.

Tudo que eu devia fazer fora estabelecido há muito tempo. Aliás, eu aprendera, na Faculdade, com o catedrático de Imobilismo Estrutural, que não devia propor nenhuma idéia nova ou ensaiar qualquer alteração nas organizações para as quais eu fosse nomeado, cuja perfeição e cuja continuidade, em grande parte, dependeriam do meu silêncio.

Pagavam-me bem, e, vez por outra, concediam-me aumentos, sendo-me vedado discutir as respectivas porcentagens.

A certa altura, eu andava cansado, aborrecido, procurando não sabia o quê e me ocorreu que talvez fosse bom ficar desempregado uns tempos. Pedi demissão. Não me foi concedida. Alegaram-me 
que eu ia ser transferido para um clima talvez menos benigno, porém mais adequado à minha natureza. É que, na outra cidade, me esperava a mulher com quem eu devia casar-me.

Protestei. Não sei pro que, mas protestei. Responderam-me que eu não tinha qualquer aptidão para escolher esposa, que eu me inclinava por mulheres totalmente inadequadas ao meu gênio e que a escolha feita por eles tinha em vista apenas o meu bem-estar. Acrescentaram que eu teria três filhos, com um e dois anos de intervalo entre eles, deram-me a lista de nomes para o sexo feminino e outra para o masculino. A casa onde devíamos morar estava pronta e a transação já aprovada: eu tinha de comprá-la a prestações. Já encontraria dentro a mobília, as roupas. Isto porque temiam que eu comprasse tudo errado, podendo assim prejudicar-me e prejudicar a família.

Transferi e casei-me. Minha mulher é ótima, deu-me os três filhos que eu devia ter, eles têm os nomes que deviam ter e eu levo a vida que devia levar. Levanto-me na hora que devo sair, faço o que devo fazer, penso o que devo pensar, digo o que devo dizer, como o que devo comer e sou profundamente grato aos que, sem consultar-me, sem interrogar-me, organizaram tão bem e tão paternalmente a minha existência.

Mas, nos últimos tempos, dois tipos de perguntas, perfurando como vermes toda a minha ventura, vêm insinuando-se. Pergunto se, cuidando tanto de mim, tanto me protegendo, na verdade não cuidaram eles de si: se não se protegiam a eles. Pergunto se, afinal, já que a vida é minha, se sou eu que arc com ela, não tinha o direito de, ao menos uma vez, ser ouvido sobre o meu destino. Ainda: penso que o mundo não pertence apenas a eles, mas também a mim e que talvez eu tenha igualmente o direito de opinar sobre o mundo. Finalmente: se eles decidem por mim, quem decide por eles? Sim, eu gostaria ao menos de substituí-los. 


\section{ANEXO 5}

Transcrição de aulas - Curso História da Arte

\subsection{Aula de pintura 1}

Tendo em vista a ausência de museus em nossa cidade, e mesmo nas grandes capitais brasileiras, uma vez que o nosso país é bastante pobre em acervos artísticos, decidimos, como parte do curso de literatura brasileira, organizarmos periodicamente pequenas sessões audiovisuais de artes plásticas. Pretendemos, assim, fazer uma retrospectiva indo, dentro do possível, das primeiras civilizações humanas aos nossos dias.

Achamos que as artes se relacionam e que uma certa familiaridade com a escultura e a pintura nos oferecem mais alguns instrumentos para abordarmos com segurança maior o problema literário. A primeira coisa que nos chama a atenção, quando nos ocupamos das artes é a insistência, dizemos melhor, a persistência com que elas têm acompanhado desde a mais remota antiguidade a aventura humana. Outro que consideramos da maior importância para nossos estudos é a freqüência com que os artistas, tanto os primitivos como os civilizados, tendem a modificar a natureza, a criar formas e imagens que não constituem apenas uma cópia, uma repetição das formas existentes. A arte busca sempre uma transfiguração, uma visão rebelde e se possível nova do real. Isso será observado com frequiência em nossas sessões dedicadas às artes plásticas.

Parece, aliás, oportuno iniciá-las com esta imagem: uma lâmpada... uma lâmpada.

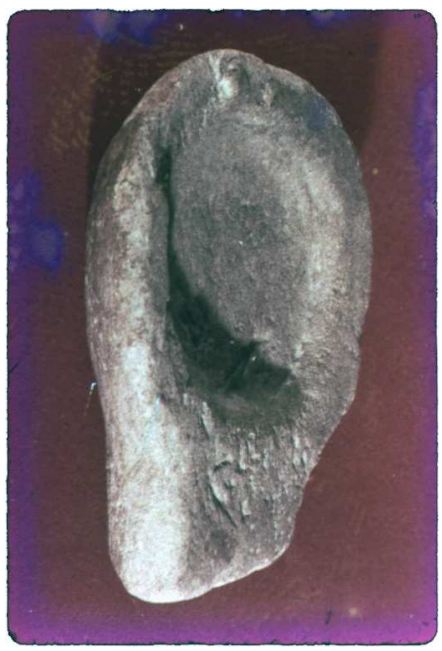

[GC_1 - 01] 
A princípio ela nada nos diz, mas uma emoção sobrevêm se nos lembramos que data do Paleolítico, isto é, da Idade da Pedra, aproximadamente um milhão de anos após a descoberta do fogo. Olhando-a, evocamos facilmente o clarão tímido que ela emitia nessas antigas noites humanas, no seio das cavernas e das florestas, presidindo as primeiras reuniões, as primeiras cerimônias de festas dançantes, talvez os primeiros contos. Ao mesmo tempo queremos apresentá-la nesta primeira aula sobre arte, como um símbolo da ânsia humana de através da arte, ver um pouco na escuridão do mundo. Em torno daquela pequena lâmpada, rugiam os animais. Muitos deles seriam reproduzidos nas paredes das cavernas, numa das primeiras tentativas artísticas.

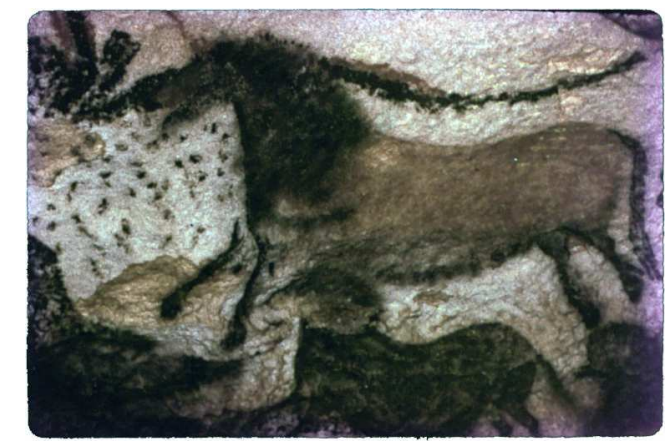

$\left[\mathrm{GC} \_1-02\right]$

Essas pinturas, chamadas rupestres, por serem desenhadas nas rochas, conquanto rústicas, revelam já um certo requinte. Em várias cores, com predominância do castanho e com traçado negro, ligavam-se, segundo os estudiosos, a intenções mágicas. Não menos rústicos, e ao mesmo tempo não menos caprichosos que as representações desses animais, eram os instrumentos com que caçavam. Também eles, a seu modo, uma pequena obra de arte.
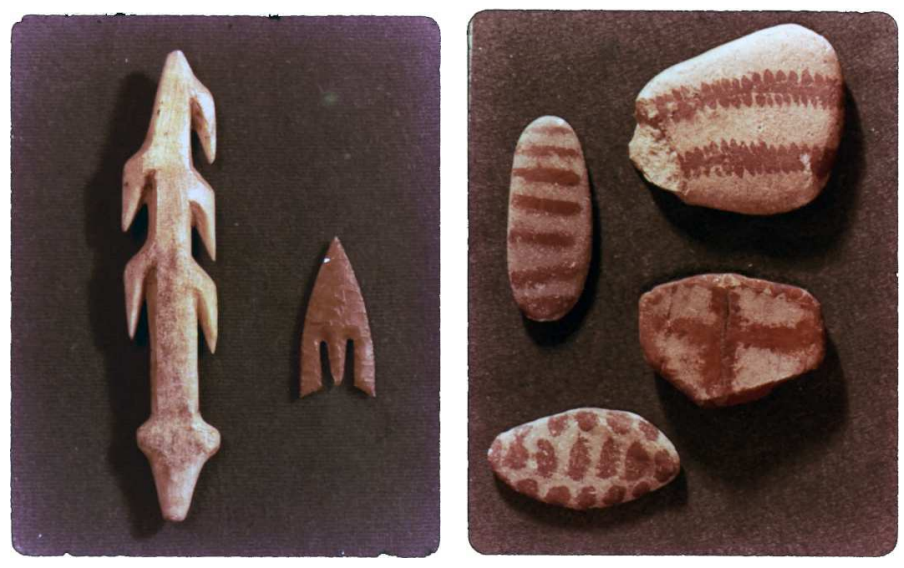

[GC_1-03] [GC_1-04]

Pontas de flecha em sílex. Data aproximada: 100 mil a 40 mil anos antes de Cristo. Registramos aqui nesses desenhos em pedra, uma tendência precoce e permanente ao esquematismo. Essa simplificação, já bastante próxima de uma arte geométrica, corresponde a uma economia de esforço e a um desejo de abstração, um refinamento substituindo por uma forma conceitual, a força viva. Mais importante ainda, estamos aí a um passo da invenção da escrita. Quer viria a se prender, mais tarde em capitulares como esta. 
Ainda na linha da estilização de formas, fato para o qual chamamos a atenção no início, esta figura em pedra, uma das primeiras esculturas da nossa pré-história.

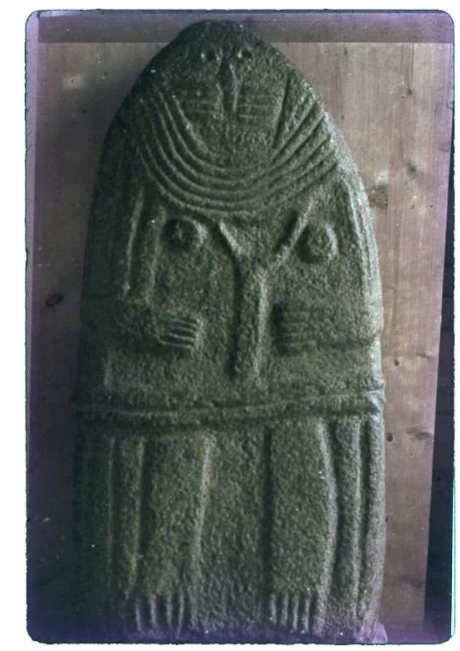

$\left[\mathrm{GC} \_1-05\right]$

Trata-se de uma mulher. Suas mãos sobre o ventre evocam a idéia da fecundidade. Observar os colares e a representação dos seios. A renovação da vida, como se sabe, foi um dos primeiros mistérios a despertar a inquietude dos homens.

Aqui já ingressamos na história.

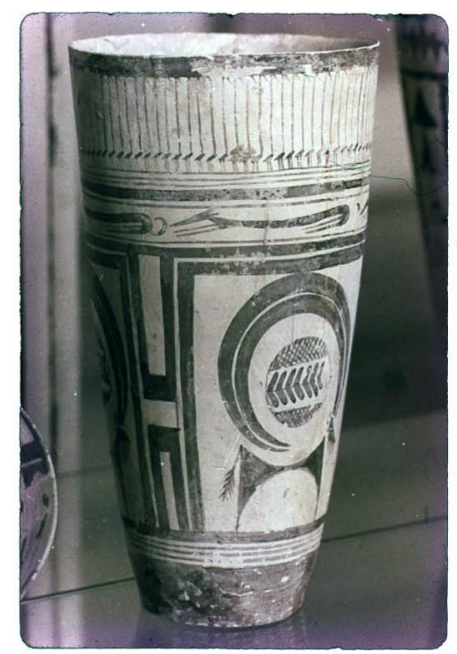

$\left[\mathrm{GC} \_1-06\right]$

Este vaso, datando de quatro mil anos antes de Cristo, vem da Mesopotâmia. Observe-se a busca quase dramática de um equilíbrio entre a forma viva e a expressão geométrica. No alto, aves aquáticas; depois, cães. Por fim, motivo principal do vaso, um cabrito montês. 


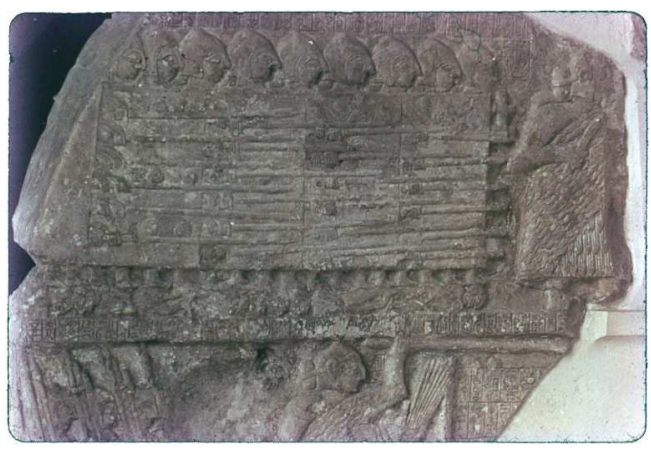

[GC_1 - 07]

Primeira metade do terceiro milênio antes de Cristo: vê-se um rei a frente de seus soldados, protegidos como ele por um capacete e escudo de couro. Armados de lanças, esmagam os inimigos. A coragem do rei, posto sozinho a frente das tropas, acentua o vigor da composição.

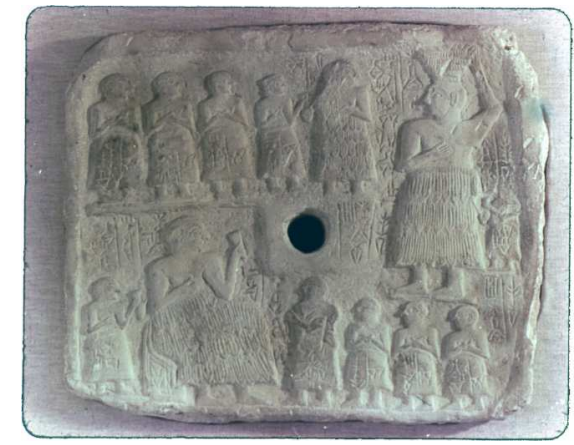

[GC_1 - 08]

Outro baixo relevo curioso, onde a principal figura, o rei, é representada duas vezes. No alto, tem sobre a cabeça uma cesta com tijolos, que servirão para a construção de um templo; embaixo concede audiência. Notar a grande simetria entre as duas cenas acentuada pelas dimensões heróicas do rei.

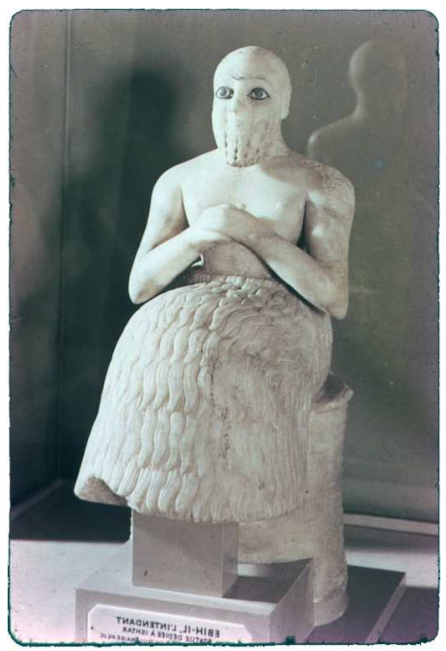

[GC_1 - 09] 
Estatueta de alabastro da primeira metade do terceiro milênio antes de Cristo, medindo cinqüenta e dois centímetros. A figura, numa atitude hierática, também é bastante estilizada. Observemos principalmente a estilização da barba e da roupa.

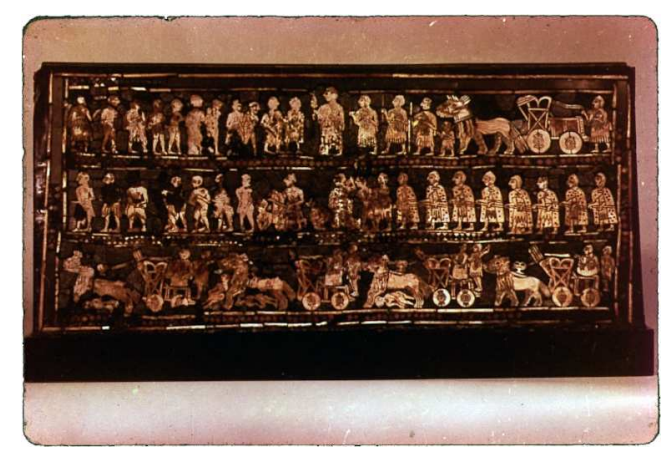

[GC_1 - 10]

Ainda da mesma época, este magnífico e ousado exemplar representa duas grandes preocupações opostas do homem: a paz e a guerra. Aqui, vemos apenas o painel alusivo à guerra. Carros de combate, movimentos de infantaria, captura dos soldados inimigos, terminando por uma oferenda dos cativos ao rei, que desceu do seu carro.

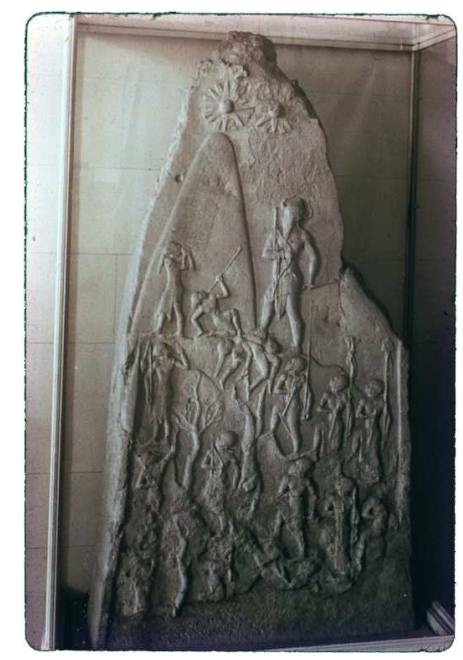

[GC_1 - 11]

Estela da Vitória de Naram-Sin. O rei, ao pé de uma montanha, esmaga os inimigos. No alto, os símbolos das divindades astrais. Notem-se os grandes espaços vazios e a liberdade de composição. 


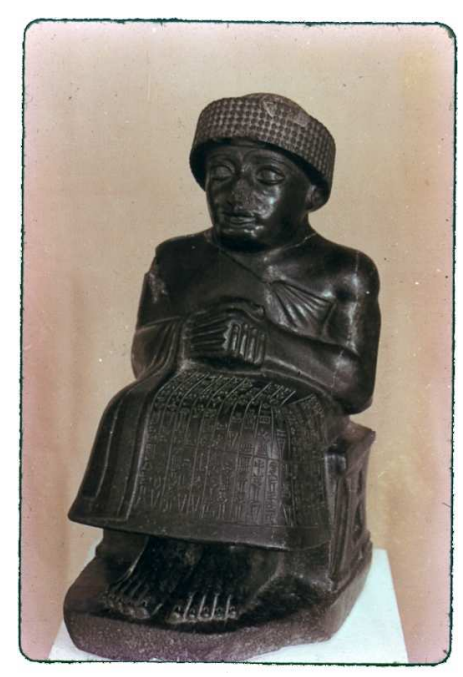

[GC_1 - 12]

Estátua interessantíssima data do XXII século antes de Cristo. Arte extremamente sóbria, e como assinalamos mais uma vez, estilizada com tendência para o abstrato, embora a musculatura do modelo seja acentuada. Observemos a grande inscrição na sua roupagem.

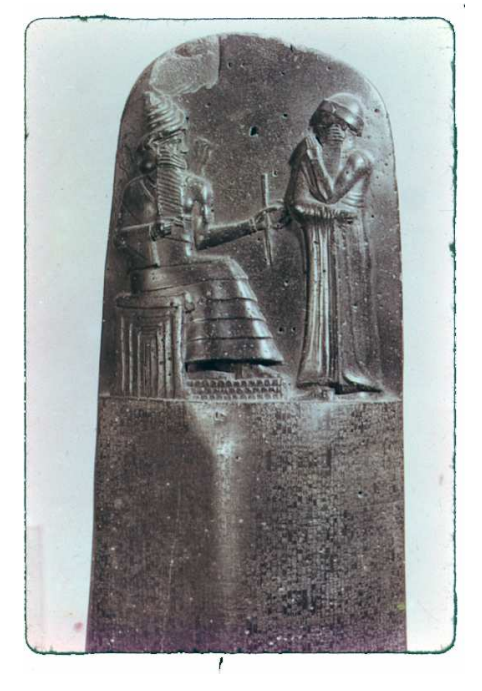

[GC_1 - 13]

Documento da mais alta importância histórica, o código de Hamurabi, de pé ante o deus da justiça. O deus dita o código. Estão no alto de uma montanha, e, aspecto curioso, a montanha é assinalada pelas escamas sob o trono divino. Evoca-nos naturalmente Moisés e o decálogo. Há fragmentos de códigos anteriores da Mesopotâmia. O de Hamurabi é o mais longo de todos: 250 artigos abrangendo toda a vida legislativa, social e econômica do país. A dureza da pedra acentua o valor divino e a permanência do código. 


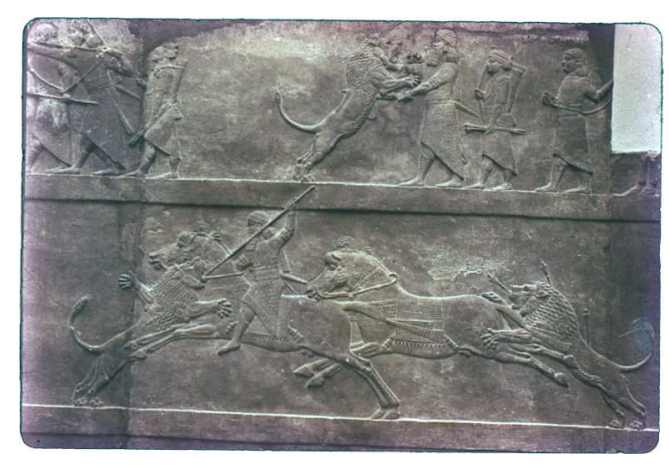

[GC_1 - 17]

A civilização mesopotâmica inaugura, em grande escala, a vida agrícola. Este baixo relevo é alusivo à vida campestre, IX século antes de Cristo. Esta é a primeira representação de caça de um rei assírio, Assurbanípal. O rei, que atravessou um leão com a sua espada, pé, ergue a lança contra um segundo. Há toda uma sala no museu britânico ocupada por esses frisos: todos imponentes e executados com grande finura.

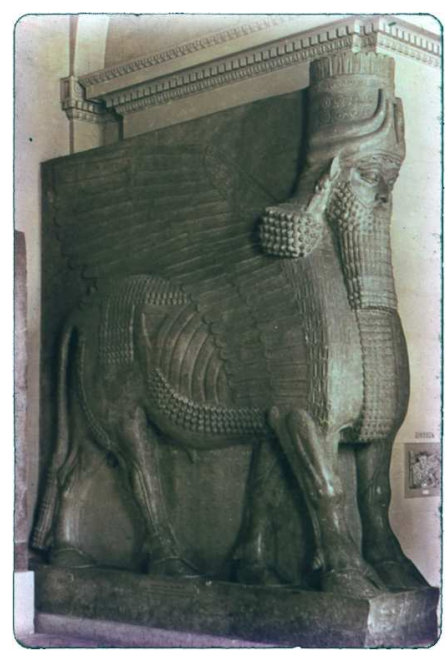

[GC_1 - 18]

Touro alado com cabeça humana. Altura: 4 metros e 20, século oitavo antes de Cristo. Geometrização acentuada contribuindo para a magia da figura. Notemos que ela é representada com cinco patas e não com quatro, possivelmente para dar uma impressão de movimento.

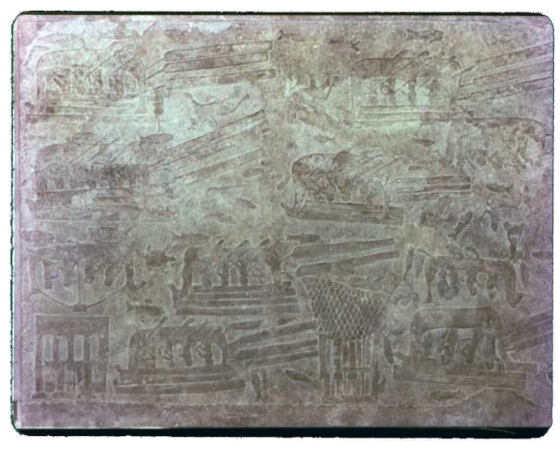


Alabastro do VIII século antes de Cristo, com a altura de quase três metros. Barcas com quatro remadores transportando vigas para a construção. Na Mesopotâmia, havia falta de madeira, quase sempre importada do Líbano. Notar a absoluta ausência de perspectiva. As figuras são apresentadas todas como estando no mesmo plano e à mesma distância. A noção de perspectiva só viria a surgir muito mais tarde.

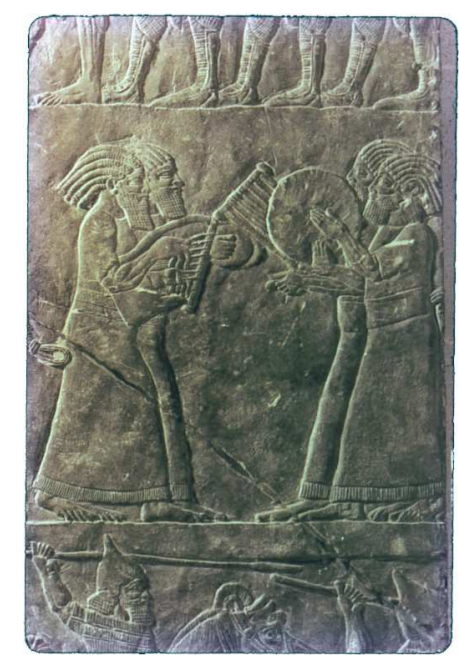

$\left[\mathrm{GC} \_1-20\right]$

Pequeno baixo-relevo de 38 centímetros em alabastro. Músicos, com os cabelos, os gestos e as roupas bastante estilizados - principalmente os cabelos - fazem soar seus instrumentos. Notável assimetria das figuras.

Deixemos agora a Mesopotâmia e passemos à outra grande civilização antiga apenas um pouco mais recente: o Egito. Esta é a primeira grande construção arquitetural em pedra de que se tem notícia.

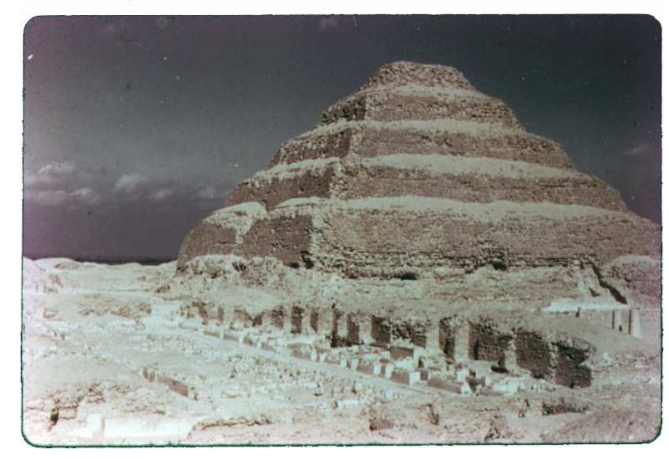

$\left[\mathrm{GC}_{-} 1-24\right]$

Com uma base de 120 metros por 109, seis degraus e cuja altura primitiva seria de sessenta metros, este monumento foi concebido para abrigar, por toda a eternidade, o corpo do faraó Gizé. Havia entre os egípcios e a morte uma espécie de relação permanente, uma luta, uma recusa. O monumento que contemplamos é um exemplo disto. Mas não apenas da morte se ocupavam os egípcios. 


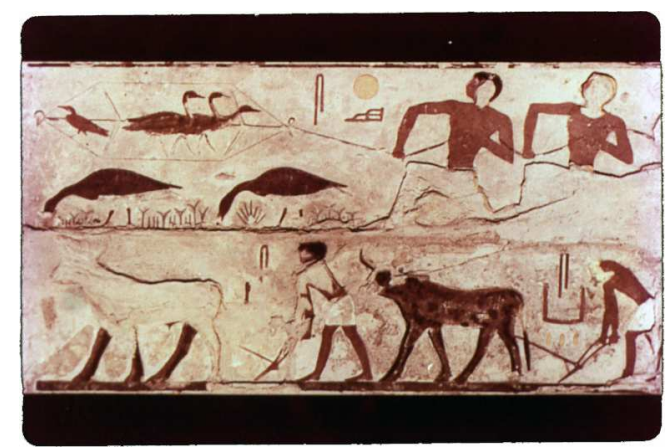

$\left[\mathrm{GC} \_1-25\right]$

Eis aqui, nesta pintura, uma curiosa cena de caça com rede e uma cena de trabalho no campo. O Egito, digamos de passagem, era uma civilização acentuadamente agrícola. Não podemos deixar de refletir, contemplando esta pintura, na luta do homem para a conquista da terra e pelo domínio dos animais que haveriam de ajudá-lo a viver.

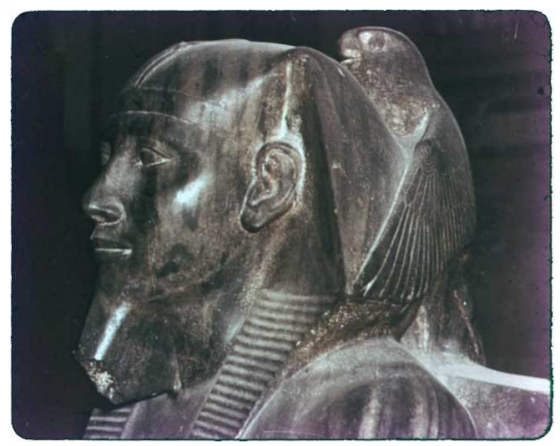

$\left[\mathrm{GC} \_1-26\right]$

A arte egípcia, também geometrizante, era sóbria e rigorosa. Linhas de grande simplicidade conjugam-se nesta cabeça do faraó Quéfren, o construtor da segunda grande pirâmide, os outros sendo Quéopis e Miquerinus. Por trás da cabeça, em forma de falcão, protege-o o deus Horus. Uma grande profundeza espiritual marcava a civilização egípcia. Esta espiritualidade reflete-se num aspecto para nós extremamente importante: a presença da escrita, uma das mais belas criada pelo homem. 


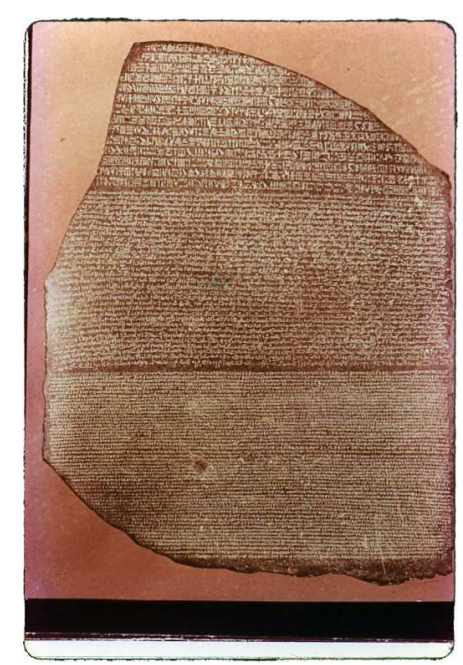

$\left[\mathrm{GC}_{-} 1-36\right]$

Aqui, a pedra de Roseta, porto a leste de Alexandria. Trata-se de um decreto de Pitolomeu quinto, 196 antes de Cristo, em caracteres hieroglíficos, demóticos e gregos. O fato de ser trilingue permitiu a Champollion decifrar, no início do século XIX, a bela e misteriosa escrita egípcia. Com essa decifração teve-se acesso, através da escrita, a uma das mais antigas e prestigiosas civilizações. Antes disso era como se os monumentos egípcios fossem mudos.

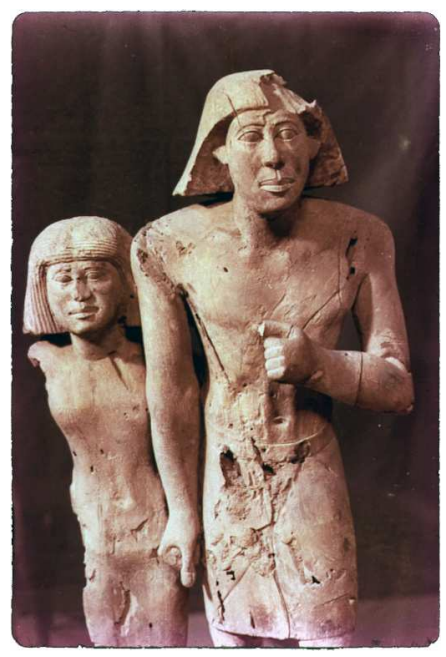

$\left[\mathrm{GC} \_1-27\right]$

De súbito, porém, os mortos silenciosos nos falaram. Ouvimos a voz dessa mulher, desse homem. Por toda a parte escreviam os egípcios. Nos utensílios domésticos, nos túmulos, nos instrumentos musicais, nos muros. 


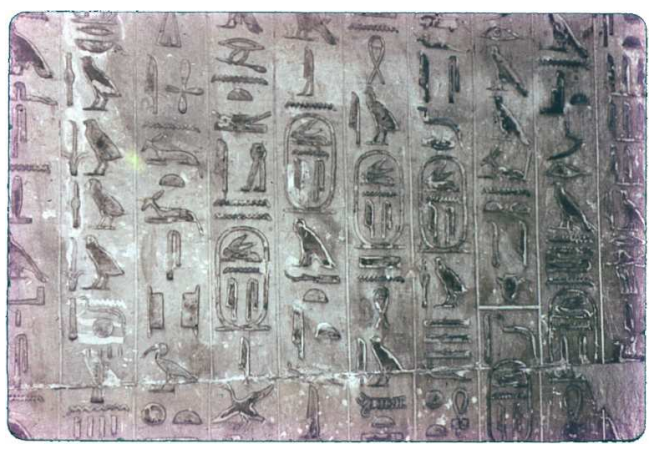

[GC_1 - 28]

Aqui, uma compilação de fórmulas litúrgicas e rápidas descrições do destino do faraó [Onás] após a sua morte. Observe-se que o nome do faraó aparece várias vezes dentro de um cartucho. Este cartucho é o disco solar alongado para melhor adaptar-se às colunas.

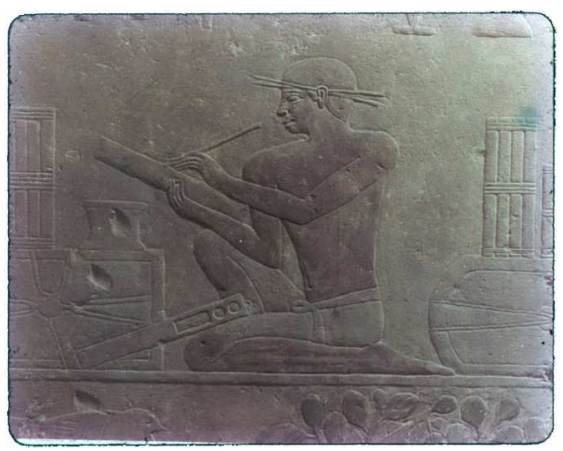

[GC_1 - 29]

Um egípcio escrevendo. Calcário pintado. Havia na arte egípcias uma lei denominada lei da frontalidade. Exigia que se contemplasse nas figuras a maior superfície possível. Esta convenção pode ser observada aqui de maneira muito clara, principalmente se atentarmos [... trecho incompreensível] o escriba serve-se do cálamo, antecessor das penas e dos [?] . Vemos um dos cálamos preso na sua orelha, hábito que ainda hoje persiste. Outro hábito da escritura egípcia que chegou aos nossos dias: usava-se a tinta vermelha para os títulos e a negra para os textos. Vemos isso atualmente nos livros da liturgia católica.

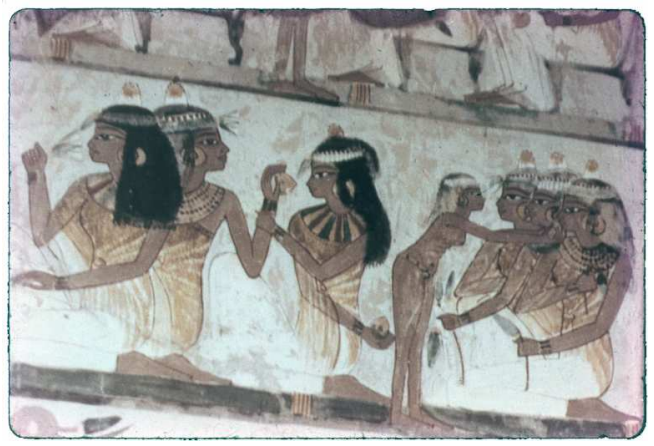

[GC_1 - 31] 
Ainda a lei da frontalidade, nesta cena de banquete. Grande estilização das figuras e extrema graça nas atitudes profundamente teatrais.

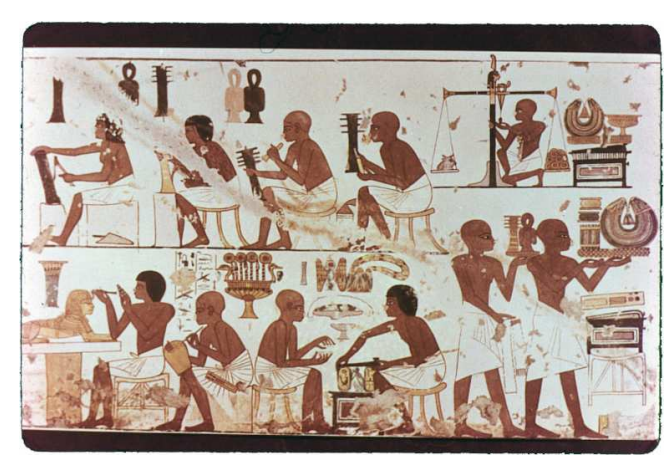

$\left[\mathrm{GC}_{-} 1-32\right]$

Artesãos entregues a seus ofícios. A lei da frontalidade é rompida em algumas das personagens.

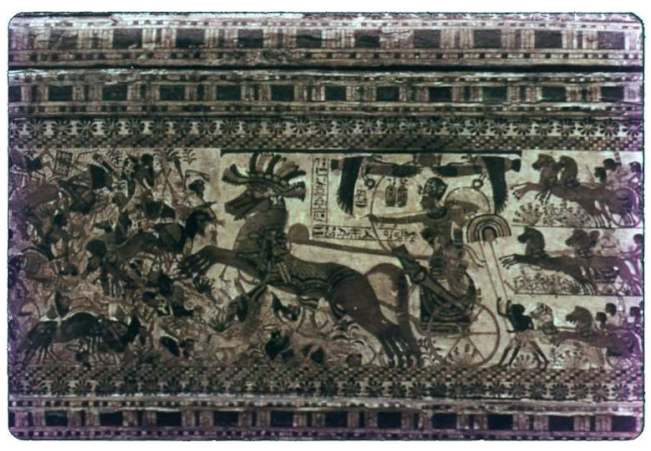

$\left[\mathrm{GC} \_1-34\right]$

Completamente diferente da imagem anterior, tanto no estilo como no motivo, a que vemos agora. Se a outra era rígida, esta é movimentada. Se a outra representava artesãos trabalhando, esta representa Tutankhamon no seu carro de guerra combatendo os assírios. Na realidade, não houve este combate. Tutankhamnn morreu ainda adolescente, mas a representação é um símbolo da vitória, após a morte, sobre os inimigos das sombras. A imponência da figura central contrasta com a disórdia dos vencidos.

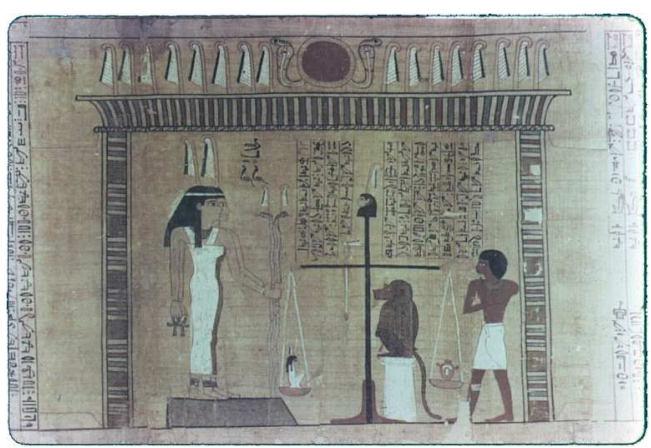


Mas voltemos à serenidade clássica das representações egípcias e delas nos dispersamos com esta pesagem da alma. Perante a deusa Maat, duplamente representada, o morto (?) deve responder pelos 42 pecados de ordem moral. Para controlar sua declaração de inocência, o coração é posto sobre o prato de uma balança e a verdade, a própria deusa Maat, no outro. O deus Thot, representado como um símio, encarrega-se do registro. Cenas de julgamento como esta passariam ao mundo bizantino e iriam influenciar mais tarde, as miniaturas dos livros sagrados e até mesmo profanos na Idade Média. Depois da arte pré-histórica, da mesopotâmica e da egípcia faremos agora uma rápida incursão à arte de Creta, da Grécia primitiva.

Creta, uma ilha do Mediterrâneo, foi de grande importância no interior da civilização helênica. Era uma civilização espiritual, pouco inclinada à guerra e caracterizada pela alegria de viver. Desempenhava o touro um papel importante na religião cretense. Não era propriamente um deus, mas ligava-se à idéia da fertilidade.

\title{
[IMAGEM ORIGINAL EXTRAVIADA] ${ }^{\mathrm{i}}$
}

Notável, nessa escultura, como se funde uma expressão de animalidade e de vitalidade com uma impressão de mistério. O mistério advém talvez da presença de traçados geométricos sobre uma cabeça moldada com grande realismo.

Presente na civilização cretense a idéia de epifania, epifania ... a revelação divina, indicada em geral nas obras de arte por um pássaro. Assim neste vaso de faïance, mil e setecentos anos antes de Cristo, a figura, muito deformada, é concebida de maneira simétrica.

\section{[IMAGEM ORIGINAL EXTRAVIADA] $]^{\mathrm{ii}}$}

Outro exemplo da epifania surge neste afresco existente no sarcófago.

\author{
[IMAGEM ORIGINAL EXTRAVIADA] ${ }^{\mathrm{iii}}$
}

Nota-se um certo parentesco entre os desenhos das figuras e das figuras egípcias. Estas porém, são menos hieráticas e revelam uma ondulação, um movimento inexistente na arte egípcia. Observe-se principalmente o desenho dos olhos, não longe da lei da frontalidade. Os pássaros, representando a epifania, aparecem nos cabos dos machados, de asas abertas.

Cântaro de pedra aproveitado pela artista como decoração, o próprio desenho do material de linhas ondulantes idênticas às linhas do próprio cântaro.

[IMAGEM ORIGINAL EXTRAVIADA] ${ }^{\text {iv }}$ 
Esta em mármore; notemos o estilo abstrato evocador de certa arte contemporânea. Há um abandono claro do detalhe e uma concentração no essencial. Nenhuma preocupação com a representação realista do modelo. Mais uma vez presente a tendência transfiguradora da arte.

\section{[IMAGEM ORIGINAL EXTRAVIADA]}

Fragmento de um afresco: o olho, também neste caso, faz-nos recordar a arte egípcia. A título de curiosidade, informamos que essa figura é chamada pelos arqueólogos, devido ao seu ar gracioso e vivaz, a pequena parisiense.

[IMAGEM ORIGINAL EXTRAVIADA] $]^{\mathrm{v}}$

Recipiente em pedra decorado com relevos:

[IMAGEM ORIGINAL EXTRAVIADA]

Outro vaso, este em ouro, proveniente de um túmulo. Idade: 1500 antes de Cristo. Trata-se, aliás, de objeto extremamente raro. Não eram comuns em Creta, utensílios em ouro.

\section{[IMAGEM ORIGINAL EXTRAVIADA] ${ }^{\mathrm{vi}}$}

Outro objeto de ouro, aqui um pandantife. Seria apenas um adorno? Teria uma função simbólica e mágica? As duas abelhas, com um raio de mel, apresentam perfeito equilíbrio entre realismo e abstração. A composição das asas, dos corpos e, sobretudo das patas das abelhas revelam o senso agudo do estilo. A abelha, animal simbólico aparece em quase todas as civilizações do Mediterrâneo.

$$
\text { [IMAGEM ORIGINAL EXTRAVIADA] }]^{\mathrm{vii}}
$$

Belo objeto de cerâmica, este cântaro, com a sua decoração em S, tão aliada a forma. Note-se, nessa decoração essencialmente abstrata, um grande dinamismo.

$$
\text { [IMAGEM ORIGINAL EXTRAVIADA] }]^{\mathrm{viii}}
$$

Outro tipo de vaso mais recente. Aqui, o motivo principal é um polvo. A forma do vaso é simétrica e a decoração assimétrica. O desenho do polvo de tendência naturalista mantém, contudo, o nítido sentido ornamental. 


\section{[IMAGEM ORIGINAL EXTRAVIADA] ${ }^{\text {ix }}$}

Bem diverso é o desenho deste vaso destinado a mistura de líquidos. Há uma deformação intensa da figura do animal com a finalidade de adaptá-lo à forma do recipiente. Além disso, enquanto o corpo do cavalo é representado de perfil, a sua cabeça é vista de frente. A crina decompõe-se em puros ornamentos. Nota-se um certo maneirismo, uma certa debilitação que faz atribuir esta cerâmica a uma época tardia.

\section{[IMAGEM ORIGINAL EXTRAVIADA $]^{\mathrm{x}}$}

Nossa incursão pelo domínio da arte antiga termina hoje com esta máscara de ouro.

\section{[IMAGEM ORIGINAL EXTRAVIADA] ${ }^{\mathrm{xi}}$}

Trata-se evidentemente de uma máscara mortuária e foi encontrada num túmulo. Concluímos com ela, simbolicamente, por dois motivos a aula de hoje: sobreviver à morte não parece ser uma das finalidades da arte? Por outro lado, vemos nos olhos fechados da máscara uma imagem da nossa própria cegueira em face do universo. Uma cegueira que a arte busca ultrapassar.

As informações sobre os dispositivos apresentados baseiam-se nos livros:

- Imagens das grandes civilizações: Pré-história, Mesopotâmia, Egito de Pierre de Bourguet, Professor de Egiptologia no Instituto Católico de Paris;

- Creta e a Grécia Primitiva - Friedrich Matz

O fundo musical constou de três peças modernas fazendo um contraste com as épocas vistas:

- Ciclos: peça para um percussionista de Stockhausen

- Refrán: para três executantes também de Stockhausen

- Ivan Parick, compositor moderno checo, sonata para flauta desacompanhada.

Agora, na parte final, canções para auto, flauta, celo e piano de (m)Biroslav Basic. Instrumentos utilizados nas peças de Stockhausen: marimba, pedaços de madeira, sinos indianos, símbalos, triângulos, vibrafone, gongo, tantã, piano, seresta, símbalos antigos etc.

Muito obrigado 


\section{BIBLIOGRAFIA CONSULTADA PELA PESQUISADORA:}

BOURGET, Pierre du. Egipte. Suisse: Editions Rencontre Lausanne, 1967.

MATZ, Friedrich. Crete and Early Greece. Holland: Methuen London, 1962. 


\subsection{Grécia Clássica e Helenismo}

Nenhuma das antigas civilizações exerceu tanta influência sobre a arte ocidental quanto a civilização grega. Seu teatro, com os grandes e poderosos mitos que povoam a dramaturgia de Sófocles, de Eurípedes e de Ésquilo, influencia ainda o teatro atual.

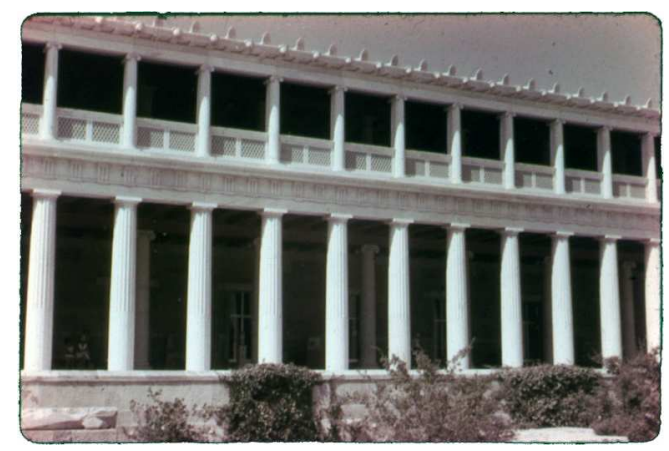

[GC_06-04]

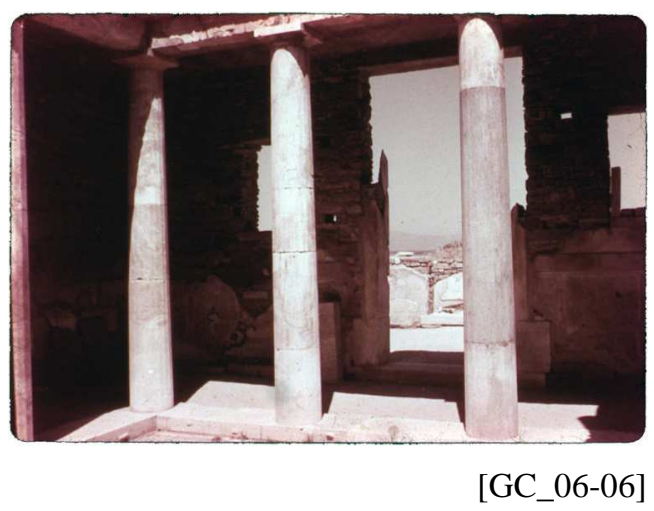

As imensas e harmoniosas colunatas dos seus edifícios públicos continuam a repercutir, transformadas ou simplesmente imitadas, em muitas construções do nosso tempo. Mesmo as suas deidades como Dionísio, Sátiro e Hasmênades, que contemplamos nessas pequenas esculturas de bronze, nas quais acentuaríamos os gestos extremamente graciosos, povoam ainda o mundo presente.

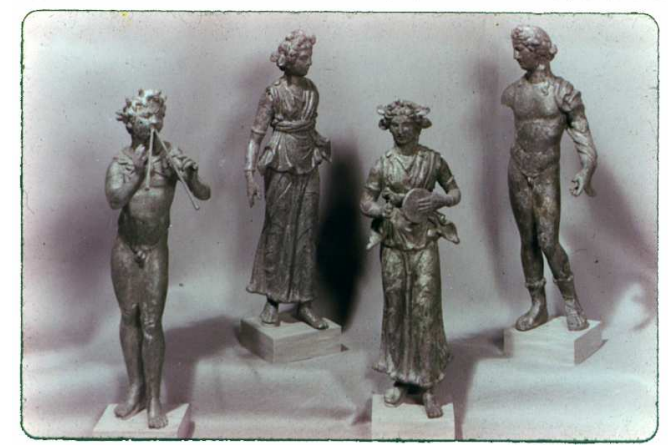

[GC_06-21] 
Vemos, nas ruínas desse mundo propenso à harmonia e ao monumental, uma fonte, por assim dizer, inesgotável de aprendizagem. Filósofos como Platão e Aristóteles, escultores como Fídias, dramaturgos como Sófocles, poetas como Anacreonte, arquitetos como Hiptnos, responsável pelo Partenon, são alguns dos nomes com os quais dialoga ainda hoje o homem culto do ocidente.

Há, na arte grega, além da fase arcaica com a qual tivemos um contato em aula anterior, duas fases bem definidas: a fase Clássica e o período chamado Helenístico.

Aqui, um precioso exemplar da chamada fase Clássica. O que o caracteriza? Um acentuado realismo, inclinação decidida para o figurativo e, completando das tendências, uma concepção ideal, quase matemática, da beleza das formas. Já tivemos oportunidade de acentuar a tendência universal da arte para recriar a natureza. Ao invés de copiar de um modo servil o mundo, tende o artista a inventar novos mundos. A arte clássica grega assinala um dos raros momentos em que a recriação artística vai manifestar-se não através de uma geometrização ou violação das formas, e sim através de uma intensificação ou idealização. Vê-se claramente o que afirmamos neste Hermes sustentando Dionísio.

[IMAGEM ORIGINAL EXTRAVIADA. Imagem GC_06-12] $]^{\mathrm{xii}}$

A princípio, quando encontrada essa estátua, em 1877, acreditou-se ser um original do grande escultor Praxitelis. Posteriormente verificou-se, mediante a análise, tratar-se de uma cópia, realizada com grande cuidado e habilidade.

O atleta Agis.

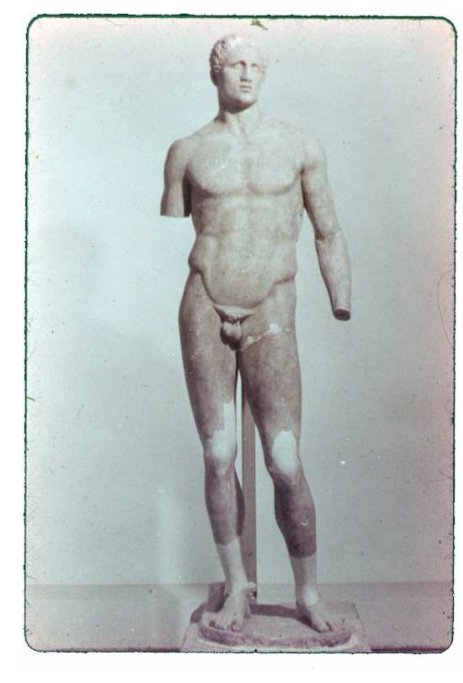

[GC_06-10]

O atleta Agis, escultura de Lisipo, vinte anos mais novo que Praxitelis. Nas figuras de Lisipo, como aqui pode observar-se, a cabeça do modelo era em geral pequena em relação ao corpo. Aliás, no rosto, delicado e sensível, opondo-se ao vigor do corpo, nota-se uma expressão de vigilância um pouco inquieta, segundo escreveu um crítico. Não há propriamente repouso. Tudo denuncia um movimento rápido e potente.

Estela funerária de Helíssos. 


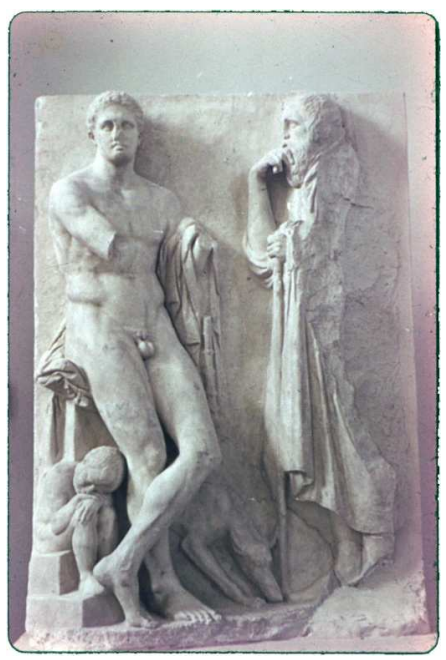

[GC_06-13]

Data aproximadamente de 335 antes de Cristo, sendo considerado um dos mais belos monumentos da segunda parte do século. O jovem atleta, meio assentado sobre um pilar que evoca o estádio, fixa-nos com serenidade. A seus pés, um pequeno servidor em atitude desolada. Junto dele um cão fareja o solo. Do lado oposto, um ancião fixa dolorosamente o rosto do filho. Essa expressão aflita contrasta com a serenidade do jovem morto. Não se conhece o autor dessa composição vigorosa e pungente.

Da mesma época é este friso do mausoléu de Alicarnasso.

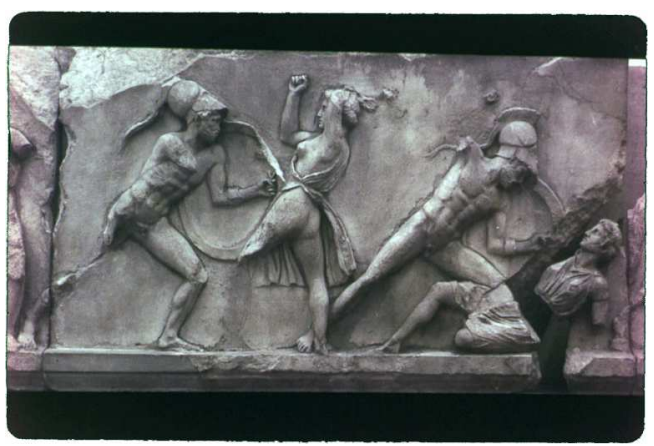

[GC_06-07]

A cena, embora movimentada, não renega a harmonia. Orienta-a, além disto, certa geometrização nas atitudes, observável principalmente em um dos combatentes no qual o torso forma linha reta com uma das pernas lançadas para trás.

O apuro da escultura grega no seu período clássico pode ser apreciado nesta cabeça de Alexandre, o grande.

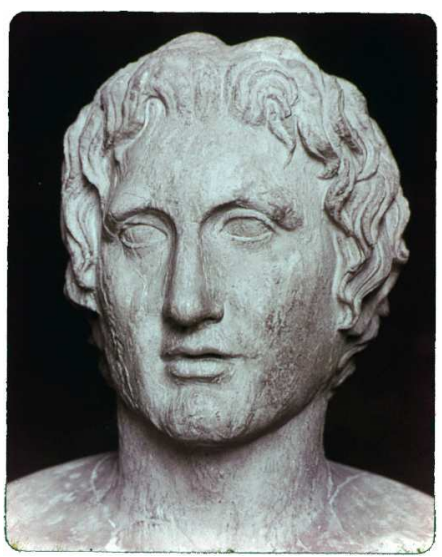


Há aí, é certo, algumas restaurações: na cabeleira, nos supercílios e nos lábios. Além disto, o nariz foi acrescentado posteriormente. Isto não afeta o realismo do trabalho. Diz um cronista: "O olho do escultor registrou impiedosamente a inchação das pálpebras, as têmporas ressecadas e certo amolecimento da carne em torno dos lábios e no rosto". Alexandre, nascido em 356 antes de Cristo, morreria aos 33 anos. Esta escultura representa-o na última fase da sua vida tumultuosa e fulgurante. Em 1900, foi encontrado o navio que há mais de 2000 anos jazia sob as águas, vitimado por um naufrágio. Levava um carregamento de mármores e bronze. Dentre os objetos existentes no barco, havia, esculpidos em bronze, um pé direito calçado com sandália, dois braços, uma parte do pé esquerdo, fragmentos da roupagem e esta cabeça de filósofo. Observar a intensa expressão de vida que emana desse rosto vigoroso, acentuada pela incrustação nos olhos ainda parcialmente conservada.

É na representação do corpo feminino que a escultura grega vai atingir os seus pontos mais altos, eternizando um certo ideal de beleza da mulher. Veja-se essa réplica de Praxitelis.

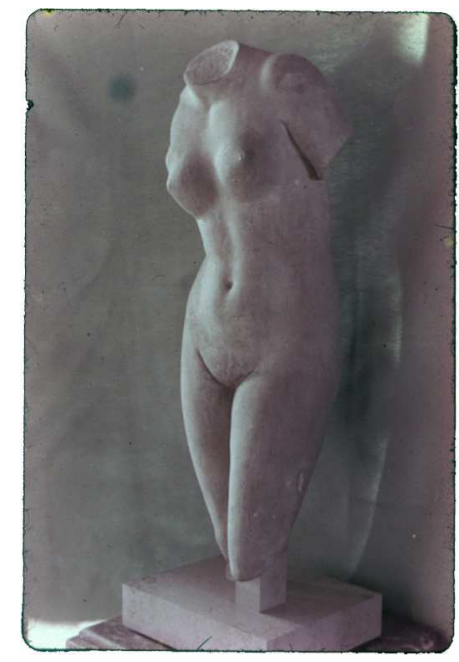

[GC_06-08]

Os ritmos sutis do torso levemente inclinado para a frente. Sobre o modelo escreveria talvez Platão: "Oh fosse eu o céu estrelado, para com mil olhos contemplar-te. Entre os vivos resplandecias como a estrela da manhã".

A Vênus de Millo: a mais bela criação talvez da estatuária clássica.

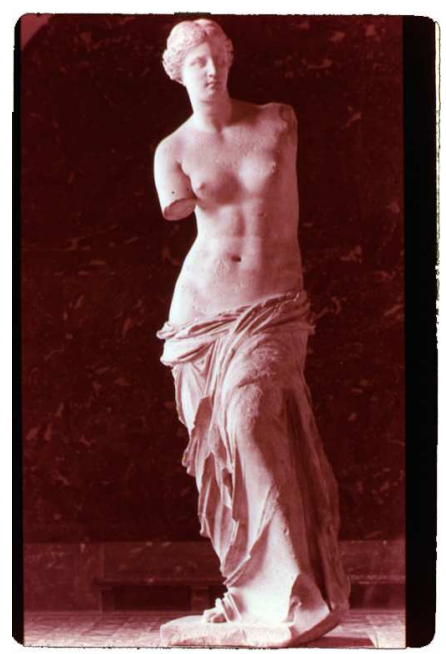

[GC_06-14] 
Autor desconhecido. Estranhamente, eis um dos mistérios da arte: a ausência dos braços, mutilados, não nos dá uma impressão penosa. A figura parece-nos perfeita e acabada na sua mutilação. Supõe-se, entretanto, que a deusa sustentaria o manto sobre a coxa direita, enquanto, na mão esquerda, erguida bem alto contemplava-se ao espelho. $\mathrm{O}$ desenho depurado do torso, um tanto idealizado, opõe-se ao realismo com que foi cinzelado o manto. Há, na atitude do corpo, uma estranha mescla de altaneria e negligência.

Bem diferente da Vênus de Millo é esta vitória, já pertencente a época helenística, na qual a tranqüilidade clássica é modificada por um anseio de movimentos.

\section{[IMAGEM ORIGINAL EXTRAVIADA] $]^{\mathrm{xiii}}$}

Por outro lado, ao contrário da Vênus de Milo, com seus dois metros de altura, a estatueta que observamos dançante, e cujas vestes parecem sopradas pelo vento, mede apenas vinte e cinco centímetros. Trabalho de uma delicadeza apurada e comovente. Sobre a amada, escreve o grego Anacreonte: "Ó tu, mais sábio e gracioso dos pintores louvados por Rodes, eleva a tua arte ao nível superior e traça os encantos de minha amante ausente. Veste-a de púrpura e faz que de seu corpo uma parte adorável surgindo dentre as dobras de seu manto, faça-nos entrever os tesouros que ali esconde ao nosso olhar".

Parece bem atender a súplica do poeta, essa Vênus, também pertencente à época helenística.

\section{[IMAGEM ORIGINAL EXTRAVIADA] ${ }^{\text {xiv }}$}

Não só a nudez e os mantos reveladores ornavam as mulheres que serviam de modelo a essas deusas repousadas ou dançantes. Broches e coroa de loureiro em ouro.

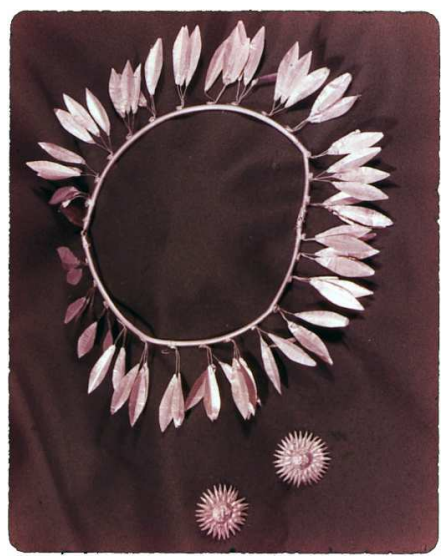

[GC_06-36]

Estes broches, em forma de margaridas serviam a fixar as pregas das vestes femininas.

Aqui, um objeto de grande elegância: uma caixa ou estojo para guardar o espelho. O motivo ornamental é Afrodite cavalgando um caprino. 


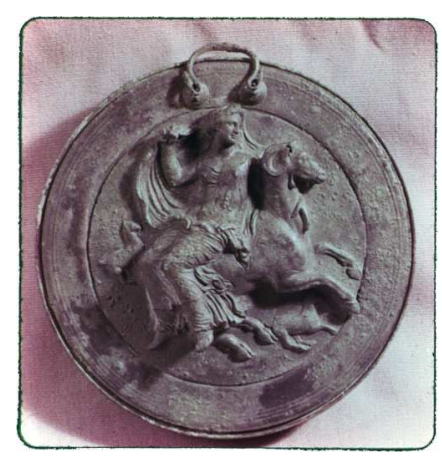

[GC_06-34]

Uma cratera, vaso destinado a misturar a água e o vinho. Material: mármore. Os especialistas assinalam nesta peça sobrevivências do período clássico numa arte já impregnada pelas novas tendências.

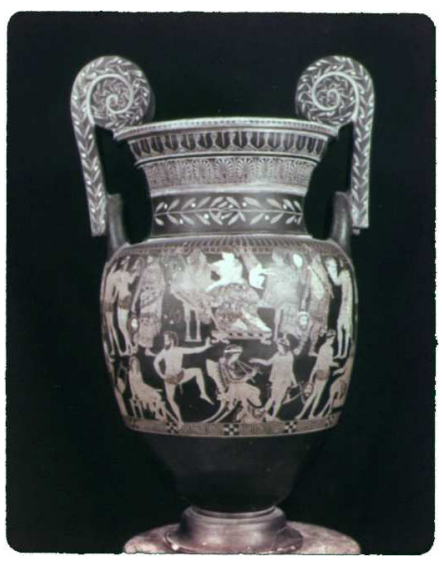

[GC_06-28]

O deus Dionísio se apóia em Ariadne que tange uma cítara. Em torno, um movimento vivo e ritmado, o cortejo dionisíaco.

O mesmo motivo, Dionísio e Ariadne, encontra-se nesta cerâmica.

[IMAGEM ORIGINAL EXTRAVIADA]

Observar a composição em dois planos.

\section{[IMAGEM ORIGINAL EXTRAVIADA]}

Outros belos exemplares de cerâmica que nos fazem novamente evocar Anacreonte, o cantor das mulheres e do vinho: "Depressa, amadas trazei-me, num grande vaso, o vinho refrescante. O calor, a sede abatem-me. Morrerei se não beber. Dai-me também algumas flores frescas. Minha fronte arde de tal modo, que ressecou, num instante, as que me serviam de proteção e ornamento. Secaram. Viverá eternamente, todavia, o violento ardor que guardo no coração.”

Com o Helenismo, instauram-se, segundo vimos o movimento e o patético. Certa dramaticidade substitui as representações clássicas.

Esta escultura, concebida, aliás, segundo a idéia da pirâmide, exemplifica bem o que queremos dizer. 
Antítese: o corpo cheio de vida do homem e o da mulher meio desfalecido.

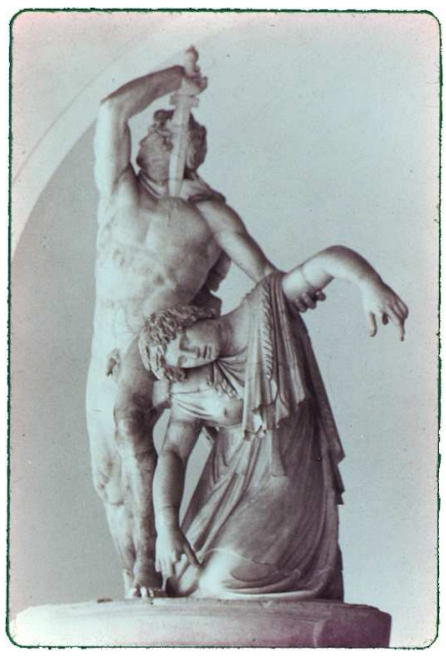

[GC_06-16]

Friso do grande altar de Júpter e Atenéia. Sempre: dramaticidade e movimento.

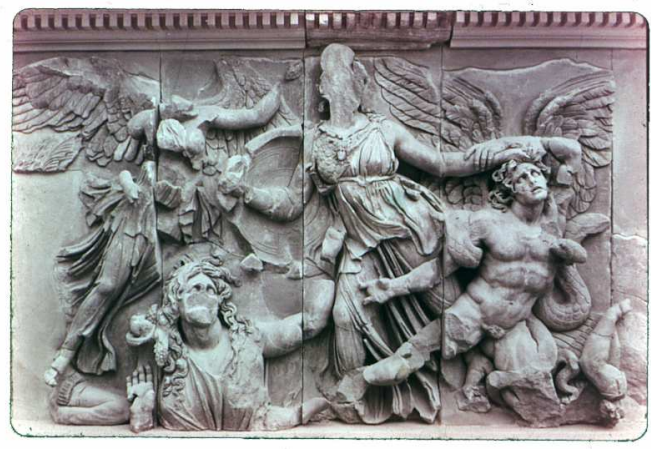

[GC_06-17]

No mesmo friso, a personificação da noite. Vejam-se a crispação das atitudes e as linhas agitadas do panejamento.

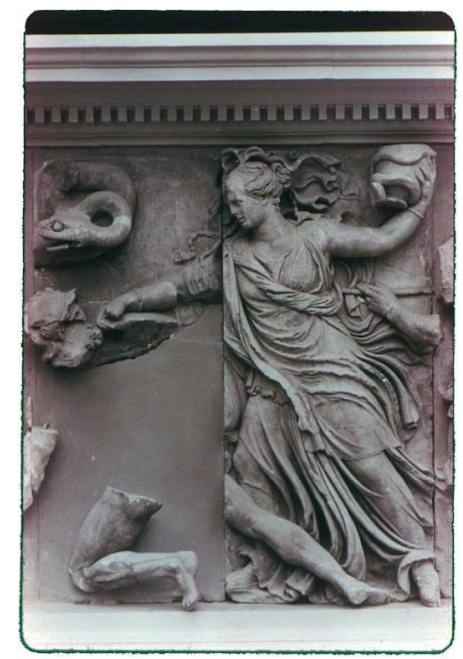

[GC_06-18] 
Caça ao leão: fragmento de um mosaico.

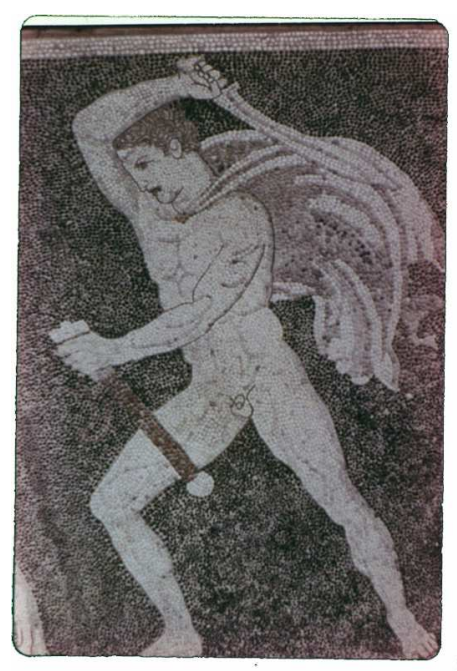

GC_06-25

As linhas principais do desenho, segundo a técnica do mosaico, são marcadas pela inserção de um fio de bronze. A arte helenística também cultiva o grotesco: Velha bêbada.

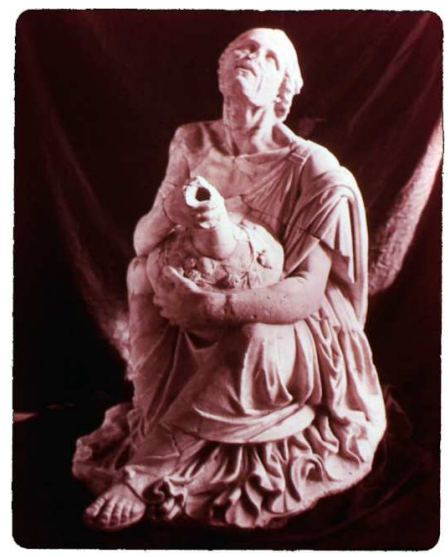

[GC_06-20]

Outro mosaico, representado a batalha de Isso, onde Dario é vencido por Alexandre. Data do século II antes de Cristo.

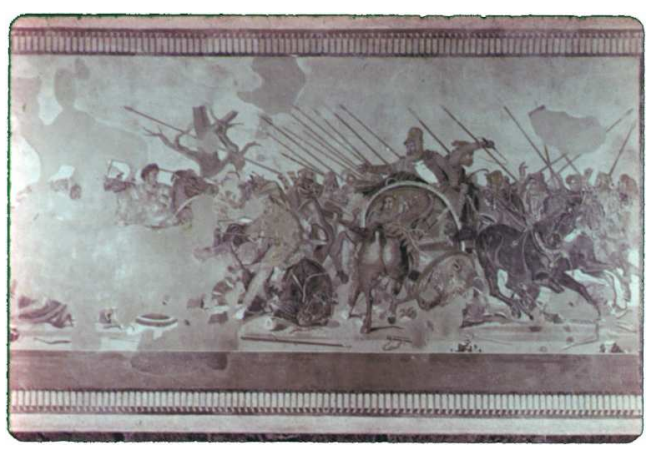

[GC_06-26] 
A título de curiosidade, vale a pena compará-la com essa batalha de Uccello, pintor florentino morto em 1475.
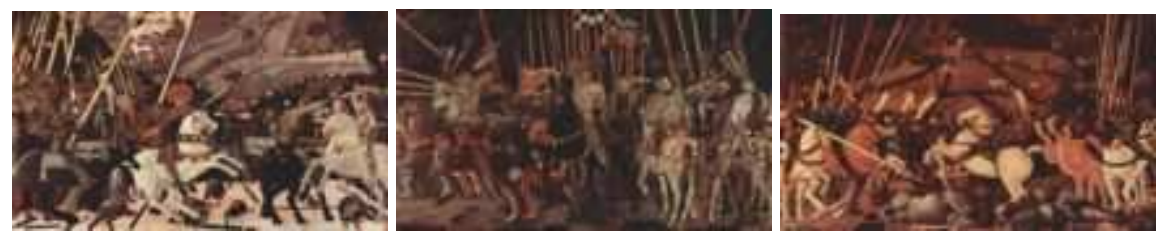

http://es.wikipedia.org/wiki/La_Batalla_de_San_Romano

Dezesseis séculos separam as duas obras, entre as quais se nota, entretanto, grande semelhança de composição.

Mas é na Vitória de Samothrace, existente no museu do Louvre, que a época helenística parece concentrar o máximo de suas virtualidades.

\section{[IMAGEM ORIGINAL EXTRAVIADA] $]^{\mathrm{xv}}$}

A estátua, que mede 2 metros e 45 centímetros de altura, ficava colocada na proa de um navio e anunciava, decerto, uma vitória naval. Poucas vezes tem a arte conseguido representar com tal felicidade, como nesta figura mutilada, a idéia de glória. Com a imagem deste corpo poderoso, a túnica transparente soprada pelos ventos, encerramos o nosso breve percurso através da arte grega, abrangendo a época Clássica e a Helenística. Quando encontrada, só o torso dessa escultura estava partido em cento e dezoito pedaços. O longo esforço no sentido de restaurá-la, não é um pouco a imagem da atividade artística, através da qual, dentre outros objetivos, buscamos uma unidade perdida? 


\subsection{Arte Bizâncio-românica}

Com o cristianismo, abre-se uma nova página na história da arte. Negligenciando a pintura primitiva cristã, não das mais importantes, e dando extenso salto no tempo, incursionemos pelo que se costuma denominar, de um modo globalizante, a arte bizantina, de que temos exemplo neste Bom pastor, da primeira metade do quinto século. Mosaico do mausoléu de Galaplácida em Ravena.

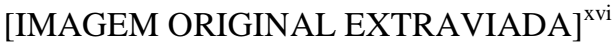

Não ocupa a arte Bizantina um território mais ou menos limitado. Ao longo, praticamente, de mil anos, abrange todo o vasto império cristão do oriente, desde Teodógio até a tomada de Constantinopla pelos turcos em, 1453. Influencia as artes na Grécia, na Ásia Menor, na África do Norte, na Rússia, nos Países Balcânicos, na Itália. O nome Bizantino vem, naturalmente, de Bizâncio que mais tarde chamar-se-ia Constantinopla e finalmente Istambul. Admirada pelos cruzados e conhecida como a cidade, era um porto natural, guarnecida de pórticos, palácios, estátuas. Quando Paris, no século XII, contava cem mil habitantes, sua população chegava a um milhão. Dentre os seus templos, salientava-se a célebre igreja de Santa Sofia, da qual disse um cronista: "Nunca o gênio de Roma e o Gênio do Oriente associaram-se num conjunto mais surpreendente e harmonioso".

\section{[IMAGEM ORIGINAL EXTRAVIADA] $]^{\mathrm{xvii}}$}

Já não temos na arte bizantina a glória do corpo e as vitórias humanas. Contam, aqui, as vitórias e as glórias de Deus.

Surgem os motivos bíblicos: o recenseamento ordenado pelo prefeito romano Cirinus, no Oriente próximo, e ao qual se submetem José e Maria fazendo a viagem a Belém:

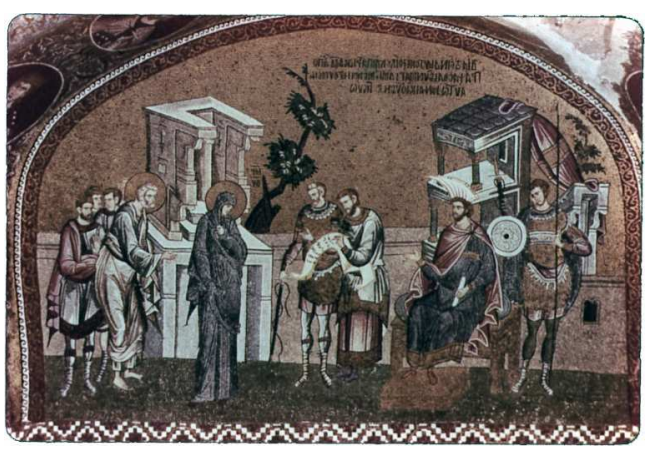

[GC_10-30] 
São Miguel: ícone considerado como obra única da arte bizantina do esmalte. Vemos aí matérias e técnicas diversas. Cabeça e mãos em ouro. Roupas combinando esmalte e ouro com filigranas. Esmaltes revestem as mangas e as asas. Já aparece aí um dos traços da arte bizantina: a suntuosidade.

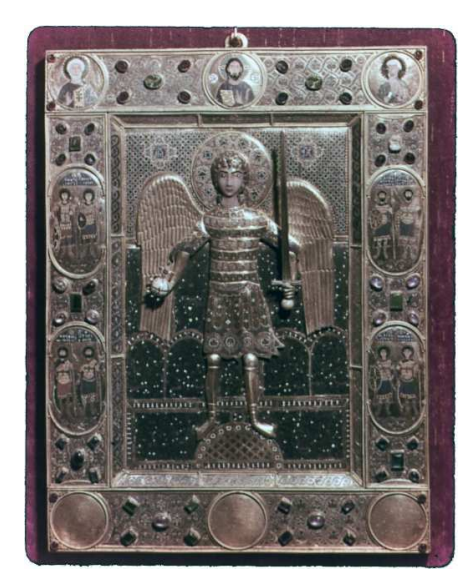

[GC_10-16]

A suntuosidade bizantina pode ser confirmada neste retábulo medindo três metros e quinze de largura por dois metros e dez de altura. Uma grande prancha de metal constelada de pedras preciosas e esmaltes diversos, do total de 85, além de incrustações de prata e ouro. Cristo promulga a lei: rodeiam-lhe quatro medalhões com os evangelistas; a Virgem, arcanjos, profetas e apóstolos completam o magnificente conjunto.

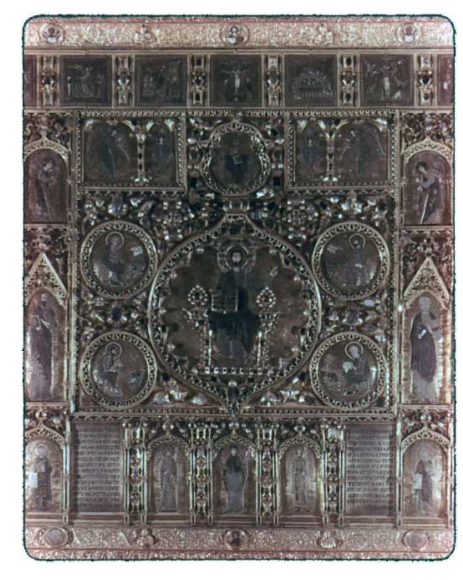

[GC_10-15]

Menos riqueza do material, mas idêntica preocupação com a magnificência das cores observava-se também nos seus manuscritos. É o que vemos nesta ilustração, representando a passagem do Mar Vermelho.

$$
\text { [IMAGEM ORIGINAL EXTRAVIADA }]^{\text {xiii }}
$$

Ou nesta outra: o paraíso, sua porta e seus quatro rios: 
[IMAGEM ORIGINAL EXTRAVIADA]

A arca da Aliança sobre as cabeças dos pretendentes a Maria:

\section{[IMAGEM ORIGINAL EXTRAVIADA]}

Ou neste mosaico portátil, com seis das principais festas do ano:

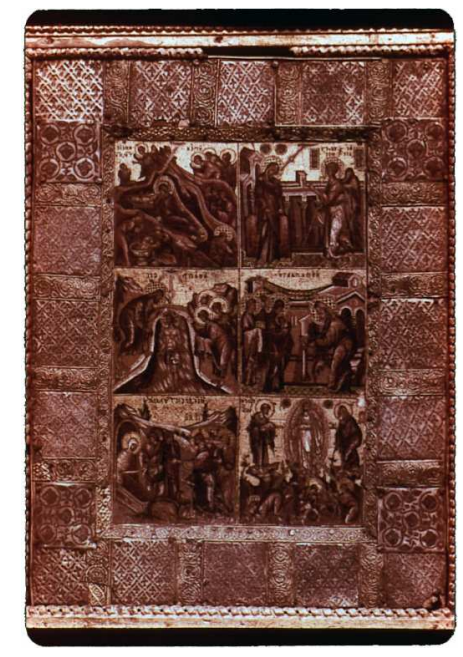

[GC_10_18]

O mosaico, aliás, foi expressão por excelência da arte Bizantina. Obedecia a uma técnica especial. Pequenos cubos de pedras ou artificiais eram embutidos nas paredes com argamassa. Incrustações, segundo a tendência que registra a arte de metais valiosos, matérias raras, e mesmo, segundo vimos, pedras preciosas concorriam para a imortal e fascinante beleza dessas obras.

A igreja de São Vital em Ravena, na Itália, abriga alguns dos mais famosos exemplares de mosaicos. Um deles é a Imperatriz Teodora e sua corte.

\section{[IMAGEM ORIGINAL EXTRAVIADA] ${ }^{\mathrm{xix}}$}

A luz exterior, penetrando pelas aberturas da igreja, modifica a iluminação desses murais e faz vibrar as cores com prodigioso número de matizes. Segundo o teor da luz, os mesmos tons ressoam diferentemente. Olhando-se por longo tempo os mosaicos, neles percebem-se as notáveis gamas das cores e a pulsação de vida que perpassa sobre essas figuras hieráticas. Vimos que uma característica da pintura egípcia era a lei da frontalidade. Segundo esta lei, era apresentada das figuras a maior superfície possível. A mesma lei transformada, surge na arte bizantina. 
Observa-se isto nos personagens desse majestoso e cintilante mosaico, que, além do mais, parecem levitar. Pormenores do mosaico: observar os olhos das figuras, perdidos ao longe, como que contemplando a eternidade.

Na mesma igreja, fazendo par com o grupo da Imperatriz Teodora, há o grupo do Imperador Justiniano e sua corte.

\section{[IMAGEM ORIGINAL EXTRAVIADA] $^{\mathrm{xx}}$}

Ambas as obras são anteriores a 547. Um fato curioso a ser anotado na arte Bizantina, era a escassa liberdade dos artistas. Obedeciam estes a verdadeiros formulários prescritos pelos padres e aprovados nos concílios. A finalidade principal da arte, aqui, era a propagação da fé. Esta coerção estilística, porém, foi superada pelos seus artistas, que nos legaram, dentro das limitações prescritas, obras como esta de Ravena.

Nela, esplendem os traços mais notáveis da arte bizantina: a frontalidade atenuada, o hieratismo, a magnificência. A riqueza e a cor sugeridas pela tendência oriental no sentido do decorativo transformaram-se num meio através do qual se procurava representar, ao lado, por vezes, da grandeza imperial, o esplendor de Deus. Mesmo o espaço celeste concebia-o o homem bizantino recoberto de ouro, diamantes e flores.

Aqui terminamos a nossa aula de hoje.

Como fundo musical utilizamos Trio de Jean Maria Oliveira e Trio de Linderberg Cardoso pelo Trio Universidade da Bahia, portanto música erudita contemporânea brasileira.

No que se refere à Arte Bizantina utilizamos música litúrgica russa, com ofício da semana santa pelos coros da catedral ortodoxa russa de Paris.

Muito obrigado. 


\subsection{Pintura Românica}

Com as profundas alterações trazidas pelo cristianismo, que abrangem todos os aspectos da existência humana, também as artes são afetadas. Vimos este fenômeno na arte Bizantina. Hierática e luxuosa com fortes influências da sensibilidade oriental. Mais tarde, outra poderosa, expressiva e original tendência estética viria a surgir e impor-se: o Românico.

Por que Românico? Sabemos que vários idiomas, entre os quais o português, procedem do latim. Paralelamente, a arte Românica é como se fosse plasticamente uma alteração das formas eruditas cultivadas pelos antigos romanos. Os artistas do período românico - arquitetos, escultores, pintores, iluministas - não têm a mesma técnica apurada dos romanos. Contudo, suas obras, animadas pelo novo espírito religioso, revelam uma espécie de força concentrada e severa que compensa as deficiências de execução.

Surgem, em vários países da Europa, templos religiosos altamente austeros, com perfis e características novos. Não é difícil identificar essas construções, surgidas à altura dos séculos X e XI e XII, e que antecedem o período Gótico. Enquanto a arquitetura gótica se manifesta por uma espécie de ambicioso impulso para o alto, a arquitetura românica permanece como que humildemente presa à terra.

A catedral gótica é inconfundível: portais e ogiva, flechas altíssimas, colunas alongadas, tudo expressões desse irresistível impulso para o alto na direção de Deus. Bem diferentes o espírito e o aspecto dos templos românicos. As torres, quase sempre de linhas verticais, são encimadas por uma pirâmide. Enquanto o gótico aperfeiçoa e cultiva os arcos de lanceta, o românico expande os arcos semi-circulares, pousados sobre colunas sóbrias e cilíndricas. Também nos pórticos, observa-se o arco semi-circular, que é, sem dúvida, uma das marcas distintivas das construções românicas.

Mesmo as janelas e os ornamentos repetem com grande constância esse arqueado. Obsessão a que o espírito do artista românico parece estranhamente ligado. Nem sempre as torres são simples. Têm, às vezes, a forma de um prisma. Contudo, nunca são muito altas, e o templo românico, em geral, mantêm outra característica: vários segmentos superpostos, provocando o conjunto uma impressão de grande severidade. Refletem bem esses templos uma certa espécie de fervor. Um fervor concentrado, um tanto soturno e, sobretudo, extremamente grave. Se há exteriormente nas igrejas românicas uma certa aridez, o mesmo não se pode dizer dos seus interiores.

São inumeráveis, na Europa, preciosos afrescos dessa época, como neste fragmento datando da primeira metade do século XII e representando a vitória do arcanjo Miguel sobre o dragão apocalíptico.

\section{[IMAGEM ORIGINAL EXTRAVIADA]}

A chamada pintura afresco é feita diretamente na parede, cuja superfície recebe uma camada cuidadosamente dosada de areia e cal. Com esse revestimento ainda úmido, isto é, ainda fresco, o pintor, com tintas dissolvidas em água, e trabalhando com muita rapidez, realiza sua obra, evidentemente por partes. Seco o revestimento, as tintas cristalizam-se e podem durar séculos. Vejam-se, por exemplo, as cores ainda brilhantes desta procissão das Santas Virgens, ainda do século XI, e, na qual, aliás, podemos notar uma influência clara da arte bizantina.

[IMAGEM ORIGINAL EXTRAVIADA]

Outro admirável afresco: Adão nomeando os animais. 
Aqui, um tema afim: a criação de Eva.

\section{[IMAGEM ORIGINAL EXTRAVIADA]}

Datam esses dois últimos afrescos de fins do século XII. Há no desenho uma certa ingenuidade e não se pode falar aqui de claro-escuro ou de perspectiva. É como se esses artistas, cujos nomes muitas vezes ignoramos, buscassem apenas, em suas sínteses, a essência das coisas. Essa busca da essencialidade vamos encontrá-la sempre com um acentuado caráter primitivo, mesmo em motivos profanos. Como nesta cena de caça a lebre, afresco da capela de Berlanga, em Castela, da primeira metade do século XII.

[IMAGEM ORIGINAL EXTRAVIADA $]^{\mathrm{xxi}}$

São apenas sugeridas as árvores, e rígidos os movimentos. Nenhuma perspectiva. O mesmo fenômeno neste portentoso elefante de combate, animal provavelmente desconhecido do pintor.

[IMAGEM ORIGINAL EXTRAVIADA $]^{\mathrm{xxii}}$

Mesmo nas obras que buscam expressar movimento, nota-se uma espécie de rigidez: anjos em adoração, afresco datando, mais ou menos, de 1100. Nota-se uma estilização obtida com meios relativamente simples, porém eficazes.

\section{[IMAGEM ORIGINAL EXTRAVIADA]}

Obra tipicamente românica este fragmento de retábulo com cenas da vida dos arcanjos. Figuras simples, nenhuma perspectiva, certa rigidez das figuras. Observar a vivacidade obtida com a alternância de fundos vermelhos e verdes.

\section{[IMAGEM ORIGINAL EXTRAVIADA]}

Outro fator de embelezamento dos templos românicos e que compensava, com a riqueza imaginativa e o vigor de execução, a severidade exterior desses monumentos arquitetônicos, eram as esculturas como esta Eva adormecida.

$$
\text { [IMAGEM ORIGINAL EXTRAVIADA }]^{\text {xiii }}
$$

Curiosamente, e isto nos faz ver ainda mais claramente a unidade de pensamento da época, em que as esculturas, em geral, caracterizavam-se por um certo achatamento das figuras. Rudes e expressivas, refletiam, nas suas proporções, a tendência dos arquitetos, que pareciam recusar, por uma espécie de humildade, o alongamento das personagens ou qualquer atitude de arrogância. Anjos e santos parecem oprimidos pela glória e pelo peso de Deus.

Outro aspecto bem curioso da escultura românica é o grotesco. O que é o grotesco? O ensaísta Wolfgang Kaiser escreveu um livro cujo o título é exatamente este: O Grotesco. Diz ele que o grotesco representa, antes de tudo, o 
fracasso da simples orientação física do mundo. E ainda, as configurações do grotesco são um jogo com o absurdo. O grotesco, aliás, está presente em quase todas as épocas artísticas, mas na época românica é notável a sua importância: o artista dos começos do milênio em que vivemos povoa o mundo de demônios e de representações do horror. Suas criações, que repousam na imaginação popular, são ao mesmo tempo ingênuas, vigorosas e expressivas. Um modo, também, de interrogar o mundo e a condição humana. [Interrupção da fita]

Encontramos também exemplos do grotesco, não nas paredes, colunas ou tímpanos dos templos, mas nos livros manuscritos, onde também esplende, em capitulares de grande riqueza inventiva, o espírito românico. Aqui, a letra A, onde variados motivos grotescamente se entrelaçam.

\section{[IMAGEM ORIGINAL EXTRAVIADA]}

Se o grotesco da iluminura anterior insinua, apesar de tudo, alegria, este, segundo a imaginação do homem medieval, procura expressar todo o horror da condenação aos infernos. O inferno fechado por um anjo. Datando de meados do século XII, pertence ao livro de salmos de Henry de Blois.

\section{[IMAGEM ORIGINAL EXTRAVIADA $]^{\mathrm{xxiv}}$}

Mas nem sempre, evidentemente, é o grotesco que vamos encontrar nas ilustrações que povoam os manuscritos dessa época, quando a arte da iluminura, uma das mais delicadas que o gênio humano tem concebido, alcança um de seus pontos mais altos. Folhear um desses livros é atravessar um mundo alegre e colorido,cheio de ornatos.

Vejamos esta letra L e cenas da vida de Ruth. Bíblia de Lambert, Canterbury, meados do século XII.

[IMAGEM ORIGINAL EXTRAVIADA]

Bem diferente, embora não menos expressiva na sua ingenuidade, esta queda das estrelas, metade do século XII. A importância da profecia é salientada pelas dimensões das estrelas. A simplicidade de meios, mais uma vez, não afeta a beleza e a grandiosidade da representação.

\section{[IMAGEM ORIGINAL EXTRAVIADA]}

Toda uma página do gênesis: a criação do homem, da mulher, a desobediência e a conseqüente expulsão do paraíso. Observar também aqui a ausência de perspectiva, a simplicidade de meios e a eficácia expressiva da obra. No teatro medieval existia também essa simultaneidade de eventos.

\section{[IMAGEM ORIGINAL EXTRAVIADA]}

Aqui, na chamada Bíblia de Winchester, uma inicial inacabada: o E. O anjo da peste abate-se sobre o povo de Israel, enquanto Davi manifesta o seu arrependimento. Esforço de síntese: algumas poucas figuras simbolizam o povo, enquanto que o isolamento de Davi é significado apenas pela sua posição. Ele está de costas para a catástrofe que o angustia.

[IMAGEM ORIGINAL EXTRAVIADA] 
Da Boêmia à Tchecoslováquia é este São Gregório rodeado por outros personagens. A ilustração data do século XII. Pormenor curioso: embaixo, pintores e um monge escrevendo.

\section{[IMAGEM ORIGINAL EXTRAVIADA]}

Aqui, uma página do chamado livro de salmos de Santa Isabel, anterior a 1217. Refere-se ao mês de julho. Em cima, por isto, o leão, signo predominante no mês.

\section{[IMAGEM ORIGINAL EXTRAVIADA]}

As iniciais ou capitulares ocupavam por vezes toda uma página dos manuscritos. Um informe: aos livros manuscritos dá-se o nome específico de códice. Os primeiros livros impressos, por outro lado, denominam-se incunábulos. $\mathrm{Na}$ época românica, anterior à invenção da imprensa, inexistem incunábulos. Contemplamos uma página de códice quase toda ornada com a capitular L. Ao lado, São Marcos.

\section{[IMAGEM ORIGINAL EXTRAVIADA]}

À Bíblia de Stavelot, datada de 1097 a 1098, pertence esta página invulgarmente bela. Com a inicial H, tão profusamente ornada, que mal a distinguimos entre as volutas e figuras, uma cena mostrando claramente Moisés salvo das águas.

\section{[IMAGEM ORIGINAL EXTRAVIADA]}

Acentuamos, mais uma vez, a superposição dos vários elementos, dispostos não segundo registra o olho humano, mas segundo os une uma visão, podemos dizer, espiritual. Notamos, nesta página, certa preocupação realista. A tendência ornamental e estilizadora manifesta-se apenas e, mesmo assim, discretamente, do traçado caprichoso de algumas folhas da árvore. A página, porém, foi escolhida e aqui apresentada para que pudéssemos apreciar a beleza das letras e, portanto, a habilidade caligráfica do copista.

A Anunciação, eis um dos temas preferidos de todos os artistas cristãos. Esta, existente no livro de salmos de Albani, data, aproximadamente, de 1125. Quase 850 anos nos separam dessa pequena obra de arte. O anjo e a Virgem, numa cercadura caprichosamente desenhada e colorida, projetam-se sobre fundo verde. O espalmado trono onde está sentada a virgem e também um retângulo por trás do anjo são azuis, como para indicar a condição celeste, extraterrena de ambos. Um ramo misterioso desce sobre o resplendor do anjo. Nenhuma preocupação de embelezar o seu rosto ou o rosto da mulher. A beleza reside no conjunto e expressa-se notadamente no colorido. Um colorido no qual ainda pressentimos ressonâncias bizantinas, e que, a seguir, viria a esplender nos magníficos vitrais da fase gótica.

\section{[IMAGEM ORIGINAL EXTRAVIADA $]^{\mathrm{xxv}}$}

Escutamos, como acompanhamento: Canto Gregoriano, música de Páscoa pelos monges beneditinos do mosteiro de Saint Morris e da abadia de Saint Mor Clevoau.

Muito obrigado. 


\subsection{Gótico}

Como sabemos, dividiu-se a primitiva arte cristã em dois grandes ramos: um oriental e outro ocidental. O ramo oriental é o bizantino. Expressa-se principalmente pelos grandes e magníficos murais de mosaicos construídos pacientemente com pequenos cubos coloridos, naturais ou artificiais, não lhes faltando a magnificência das pedras preciosas, do ouro e de outros metais de valor. O ramo ocidental, o românico, muito mais sóbrio e severo, rudimentar na técnica, às vezes, mesmo, ingênuo, era bastante deformador. Aliás, a arte românica é como se fosse, já o dissemos, uma alteração das formas plásticas eruditas cultivadas pelos antigos romanos.

Outra grande e importante expressão da arte surgiria com o gótico. Suas expressões mais características são as catedrais, e nestas, os vitrais. À noite, os vitrais, por assim dizer, emudecem. Nascendo a luz do sol, trespassados pela claridade, voltam a falar aos homens com o brilho inigualável das suas cores. Os vidros utilizados para esse gênero de trabalho eram coloridos durante a fundição. Há, em tais obras, no seu melhor período, discretas intervenções com o pincel, para precisar, por exemplo, traços dos rostos ou rugas das roupas. Os pedaços de vidro são emoldurados em chumbo, a grande armação é de ferro. Combinando linhas curvas e retas, essa armação, de certo modo, já constitui uma obra de arte. Mas o vitral, embora importante, é apenas um elemento do gótico. Originário da Ilha de França, o gótico floresceu na Europa durante o século XIII, sendo a última manifestação artística de importância anterior ao Renascimento.

Mencionam-se, na arquitetura gótica, o cruzamento de ogiva, as abóbadas de nervuras e os arcobutantes. Para nossa compreensão, entretanto, o que salta à vista no gótico é uma aspiração para o alto. Há uma reação àquela espécie de humildade que aproximava do solo os templos religiosos. Estes, agora, lançam-se para cima e parecem buscar as estrelas. Dentre os templos góticos, sobressai-se a catedral de Chartres. É o monumento mais antigo no seu gênero e aquele onde brilham com maior vigor os característicos desta arte, de que é uma espécie de súmula. Diz a seu respeito um historiador: “A outras catedrais não foram capazes de dizer-nos tantas coisas, e não as disseram numa ordem tão bela”.

O melhor modo de aproximar-se de Chartres, dizem os conhecedores, é pela estrada de rodagem vindo de Paris. A catedral surge no horizonte, desaparecendo e surgindo ao sabor das ondulações. Se estão maduros os imensos campos de trigo, a catedral, como um imenso navio, parece navegar solitária sobre este mar dourado.

\section{[IMAGEM ORIGINAL EXTRAVIADA $]^{\mathrm{xxvi}}$}

Chartres, a cidade, cheia de ruelas tortuosas com suas casas, muitas das quais de pedra, seus gerânios e seu silêncio conserva ainda certo ar medieval, constituindo uma moldura adequada para a catedral. Quando não povoada de turistas, escutamos, mesmo durante o dia, o eco de nossos passos nas pedras. Por vezes, um visitante solitário, cansado de andar nas ruas ladeirosas, senta-se à margem do Euri e fica a olhar as águas.

\section{[IMAGEM ORIGINAL EXTRAVIADA $]^{\mathrm{xxvii}}$}

Eis a catedral. No seu conjunto, tal como está, o monumento data do século XIII. A fachada, entretanto, incorporou algumas partes admiráveis já existentes no século anterior. Apresentando, embora, altura e formato diferentes, as duas torres se harmonizam. São irmãs, diz-se, mas não gêmeas. O arquiteto da torre situada à direita, a mais alta, quis provavelmente superar o seu antecessor. Quanto à outra, de uma elegância que pode dispensar os ornamentos, foi chamada por um conhecedor do porte de Viollet-le-Duc, $\mathbf{O}$ rei dos campanários. 


\section{[IMAGEM ORIGINAL EXTRAVIADA $]^{\mathrm{xxviii}}$}

O tríplice pórtico sul, sua amplitude, suas proporções felizes e a esplendida ornamentação fazem dele uma obra prima que o observador não cessa de admirar. O fato de ficar em posição elevada realça-o. Figuras de santos e de reis entrelaçam-se com o ornamento de pedra de uma delicadeza de renda.

\section{[IMAGEM ORIGINAL EXTRAVIADA] $]^{\mathrm{xxix}}$}

A entrada principal, como as demais, revestida de esculturas todas alongadas, obedientes a tendência do gótico para o alto. As esculturas repousam sobre pedestais de forma cilíndrica. Tal é a riqueza de invenção, a recusa à repetição, que cada pedestal apresenta um motivo ornamental diferente. Aproximemo-nos. Observemos a porta central. Uma informação: as pedras destinadas a estes trabalhos, eram, muitas vezes, trazidas de lugares situados a mais de dez quilômetros da cidade. As pessoas que se ofereciam para ajudar nessa tarefa, em geral, confessavam-se antes de seus pecados e procuravam reparar o mal que acaso houvessem feito a seus semelhantes.

\section{[IMAGEM ORIGINAL EXTRAVIADA $]^{\mathrm{xxx}}$}

Portal sul: o tema é o juízo final, freqüente na arte religiosa, e que aqui retorna com o sentido do grandioso, próprio do gótico. A composição, por assim dizer, dispensa comentário. Rodeado de anjos com os instrumentos da paixão, Jesus mostra suas chagas. A Virgem e São João intercedem pela humanidade.

\section{[IMAGEM ORIGINAL EXTRAVIADA] $]^{\mathrm{xxxi}}$}

O portal norte, que representa a coroação da Virgem. Escreve Émile Mâle: "Dir-se-ia que as estátuas de Chartres foram moldadas com o limo primitivo, contemporâneas, portanto, dos primeiros dias do mundo." Surgem seus patriarcas e profetas, verdadeiramente como os pais dos povos, como as colunas da humanidade.

\section{[IMAGEM ORIGINAL EXTRAVIADA] $]^{\mathrm{xxxii}}$}

Apóstolos do portal sul: estas esculturas são do século XIII, informam os historiadores da arte. É a primeira vez que os apóstolos aparecem esculpidos no portal de uma igreja. Em pormenor, uma das quinas do templo. Não há, pode-se dizer, um só ponto nessa imensa obra de arte que dispense o nosso olhar e o nosso exame. Fundem-se aí a grandiosidade da concepção e a minúcia da execução. Notar os motivos ornamentais em torno das estátuas.

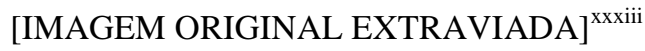

Personagens bíblicos do portal norte. Acentuada estilização das figuras no sentido longitudinal. Há um admirável equilíbrio entre natureza e estilização. Observemos as barbas e os mantos apresentados de maneira quase geometrizante. A esse grande exemplar da arte medieval foram acrescentadas em épocas posteriores algumas contribuições, como a torre do coro, que, iniciada nos primeiros anos do século XVI, prosseguiu até o fim do reinado de Luis XIV, com a duração aproximada, portanto, de um século. Aí, já nos defrontamos com o Neo-classisismo que marcaria a Renascença e 
que podemos observar facilmente nas figuras humanas. Foi abandonado o alongamento que notávamos nas esculturas dos séculos precedentes.

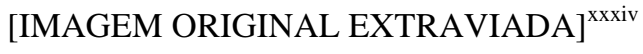

A representação, agora, menos transcendental, assume um compromisso declarado com a natureza, como se vê nesse Batismo de Cristo.

$$
\text { [IMAGEM ORIGINAL EXTRAVIADA] }]^{\mathrm{xxxv}}
$$

Salienta-se, na torre do coro, o relógio. Quando estudarmos a arte renascentista, reencontraremos alguns dos motivos ornamentais aí existentes. Mas também o Barroco aí se insinua. Atente-se, neste sentido, para os panejamentos da figura ao lado do relógio.

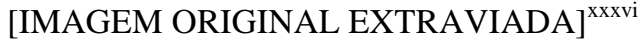

Giremos agora em torno da catedral. Observemos a complexidade das suas arcadas, dos seus arcobotantes, as caprichosas soluções arquiteturais. Ter-se-á por vezes a impressão de estar no centro de uma roda gigantesca ou de numerosas rodas que se entrelaçam, resultando numa espécie de vertigem.

\section{[IMAGEM ORIGINAL EXTRAVIADA $]^{\mathrm{xxxvii}}$}

Voemos e contemplemos mesmo a coberta de cobre. Adquiriu com o tempo uma pátina verde que se harmoniza com a tonalidade das pedras. Ao longe, a paisagem plana e tranqüila.

$$
\text { [IMAGEM ORIGINAL EXTRAVIADA }]^{\mathrm{xxxviii}}
$$

Mas, penetremos no templo. A perspectiva interior da nave, com as suas ogivas, seus vitrais, a aspiração para o alto, não destoa em nada do exterior: a mesma solenidade e a mesma grandeza. Pode-se dizer que não existem paredes e sim, apenas, suportes.

Uma das portas do claustro da Notre Dame das quais subsistem apenas duas. O traçado aí é antes Românico que Gótico. As fontes batismais situadas na cripta, ou seja, na parte subterrânea do templo, datam do século XII. Estavam abandonadas e só em data recente foram restauradas e postas novamente em uso.

\section{[IMAGEM ORIGINAL EXTRAVIADA] $]^{\mathrm{xxxix}}$}

Ainda um exemplo da presença românica neste monumento gótico: arcadas e capitéis. Ficam na parte baixa de uma das torres e os capitéis apresentam apenas ornamentos vegetais que os especialistas reputam excelentes.

$$
\text { [IMAGEM ORIGINAL EXTRAVIADA }]^{\mathrm{xl}}
$$

O Românico, segundo já tivemos oportunidade de ver, era pródigo em figuras grotescas. Acredita-se que a simplicidade desses ornamentos deve-se a São Bernardo, que achava deslocados e custosos os [...] freqüentes no românico. 


\section{[IMAGEM ORIGINAL EXTRAVIADA $]^{\mathrm{xli}}$}

Escultura do púlpito: nascimento de Cristo. Maria, apoiada no braço direito, estende a mão livre para a criança. José inclina-se para a esposa e estende-lhe um manto ou uma coberta. Falta a sua cabeça, única mutilação de importância nesse baixo relevo do século XIII.

\section{[IMAGEM ORIGINAL EXTRAVIADA] $]^{\text {xlii }}$}

Quem contempla de fora a catedral, observa grandes rosáceas compreendendo motivos simétricos. As aberturas abrigam um dos maiores tesouros artísticos da catedral, expressão por excelência do gótico: os vitrais.

\section{[IMAGEM ORIGINAL EXTRAVIADA] $]^{x \text { liii }}$}

Rosácea do juízo final. Pormenor: entrada de Jesus em Jerusalém. Já tivemos a oportunidade de ver que a catedral gótica, com a sua profusão de colunas e poucas paredes, deixava pouco espaço para a pintura. Além disso, eram construções um tanto sombrias no interior. Os vitrais, filtrando, colorida, a luz exterior animam com misteriosos reflexos o piso e as colunas.

\section{[IMAGEM ORIGINAL EXTRAVIADA] $]^{\mathrm{xliv}}$}

Parte inferior de um grade vitral do século XII: A árvore de Jessé. Ótimo estado de conservação, não obstante os seus oitocentos anos. A lamentar: quase todas as cabeças foram objeto de restaurações. Do corpo do ancestral adormecido, surge o tronco de uma vigorosa árvore, cujos ramos, recurvados simetricamente, acabam em volumosos florões. Sentados uns sobre os outros, quatro reis anônimos evocam as gerações pelas quais Maria chega a Davi, pai de Jessé. Maria reina sobre os reis. Mais alta ainda, flor suprema da árvore simbólica, o filho em proporções gigantescas. Rodeiam-nos sete pombas, representando os dons do Espírito Santo. Colorido rico e harmonioso. Diz Émile Mâle: "Não existe vitral mais belo no mundo".

\section{[IMAGEM ORIGINAL EXTRAVIADA $]^{\mathrm{xlv}}$}

Outro vitral famoso: Notre-Dame de La Belle Verrière. Data no máximo de 1140.

$$
\text { [IMAGEM ORIGINAL EXTRAVIADA }]^{\mathrm{xlvi}}
$$

São Diniz e São Clemente, século XIII. Também do século XIII, partido de Carlos Magno da Espanha. Esplendentes vermelhos e azuis sabiamente dosados.

\section{[IMAGEM ORIGINAL EXTRAVIADA]}

Alguns vitrais são chamados vitrais legendários. Assim se denominam porque contam uma história, uma legenda. Este, também do século XIII, conta a história de Santo Eustáquio, santo caçador. Por isso foi doado à capital por comerciantes de peles. Também o de Carlos Magno é um vitral legendário. 


\section{[IMAGEM ORIGINAL EXTRAVIADA] $]^{\mathrm{xlvii}}$}

Conjunto admirável: A rosácea do Sul pousada sobre cinco grandes figuras de pé. Rosácea do Norte fazendo pandam com a do Sul, também posada sobre cinco figuras. Aproximemo-nos e observemos uma dessas figuras: Araão. Chamaríamos a atenção para a simplicidade dos traços, a concisão dos elementos e o grande vigor da figura. O resultado artístico nem sempre depende da minúcia. Diante desses vitrais, esquecemos por completo a natureza, qualquer exigência de semelhança, e mergulhamos inteiramente no reino da arte.

$$
\text { [IMAGEM ORIGINAL EXTRAVIADA] }]^{\mathrm{xlvii}}
$$

Outro deslumbrante pormenor do conjunto: morte e assunção da Virgem, mais um vitral legendário.

$$
\text { [IMAGEM ORIGINAL EXTRAVIADA }]^{\mathrm{xlix}}
$$

Cremos haver dado, tomando como exemplo a Catedral de Chartres, uma idéia bastante razoável da Arte Gótica. Vimos a igreja do exterior. Chegamos mesmo a vê-la do alto e nela penetramos. Notamos seus contrafortes, suas arcadas. Respiramos um pouco da sua atmosfera, deixamo-nos invadir pela solenidade dos seus interiores, vimos a luz de seus vitrais. Ao que já conhecemos da evolução das artes, mais uma noção definida e individualizada se acrescenta: o gótico.

A maioria das informações aqui veiculadas foi colhida no texto do cônego Yves de la Porte: La cathédrale de Chartres. Piblicación Filmedad edistoar.

Fundo musical: música Litúrgica Russa com os ofícios da Semana Santa.

Coros da Catedral Ortodoxa Russa de Paris.

Muito obrigado.

\section{BIBLIOGRAFIA CONSULTADA PELA PESQUISADORA:}

AUBERT, Marcel. La Cathédrale de Chartres. 100 héliogravures em noir, 8 photographies em couleurs dês vitraux de la cathédrale. France/ Paris : B. Arthaud, 1952.

DELAPORTE, Yves. Notre-Dame de Chartres. France/ Paris: Librairie Hachette, 1957.

MÂLE, Émile. Notre-Dame de Chartres. Cent Cinquante-quatre Photographies de Pierre Devinoy. Paris : Paul Hartmann Éditeur, 1948. 


\subsection{Renascimento Italiano}

Abrangendo, grosso modo, os séculos XV e XVI, isto é, indo de 1400 a 1600, temos o que se convencionou chamar o Renascimento. Renascimento de quê? Renascimento, antes de tudo, da harmonia clássica, dos característicos de equilíbrio que haviam marcado a arte greco-romana. Olhando, por vezes, as obras dessa época, temos a impressão de pertencerem ao século de Péricles, como nestes Cantores de Lucca della Robia, ou como nesta Noite de Miguel Ângelo, pormenor do túmulo de Giuliano de Médicis.

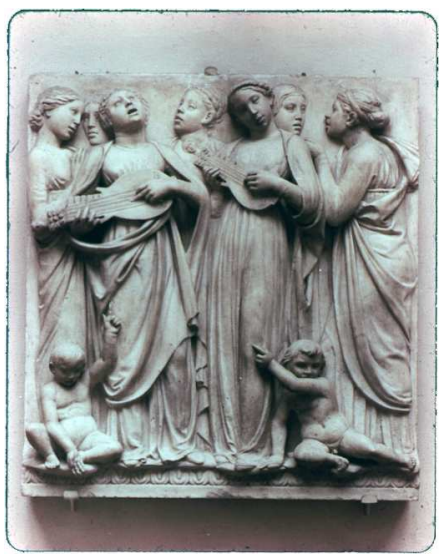

[RI_1-10]

[IMAGEM ORIGINAL EXTRAVIADA: Noite - Michelangelo] ${ }^{1}$

Sobre escultura tão perfeita, escreveu Giovanni Strotisc: "a noite que vês dormir no abandono tão doce foi esculpida nesta pedra por um anjo, uma vez que está dormindo é que vive. Se duvidas, acorda-a. Ela te falará. Ao que respondeu Miguel Ângelo, fazendo alusão à humilhação que se seguiu à queda de Florença: "Para mim é doce dormir, mais doce ainda ser de pedra nestes tempos de infelicidade e de vergonha. Nada a ver nem sentir é para mim uma sorte. Portanto, não me despertes. Fale em voz baixa."

A arte abandonava o simbolismo medieval, impregnado de religiosidade e não raro retomava os temas do paganismo. Vênus de Giambologna e em cima a fonte de Vênus de Florença, em mármore e bronze.

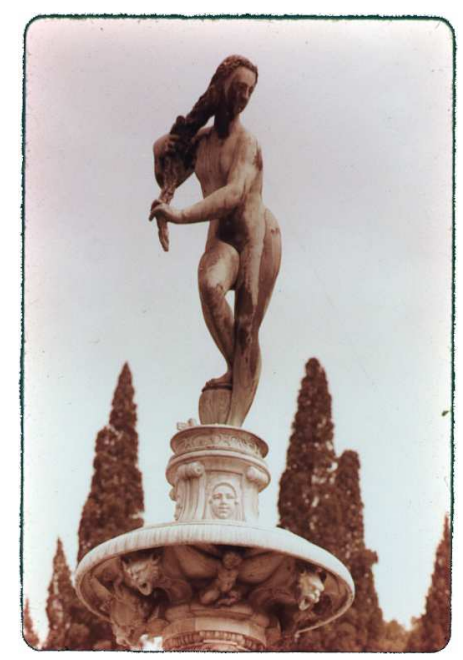


A deusa espreme a cabeleira úmida da qual escorre água quando em funcionamento a fonte. As igrejas, é certo, continuam a povoar-se de afrescos e imagens e algumas obras do renascimento, principalmente na pintura, ficariam como das mais importantes da arte sacra. O homem, entretanto é a medida e o modelo.

Mesmo temas bíblicos, como esse David de Donatello, tem freqüentemente algo de pagão.

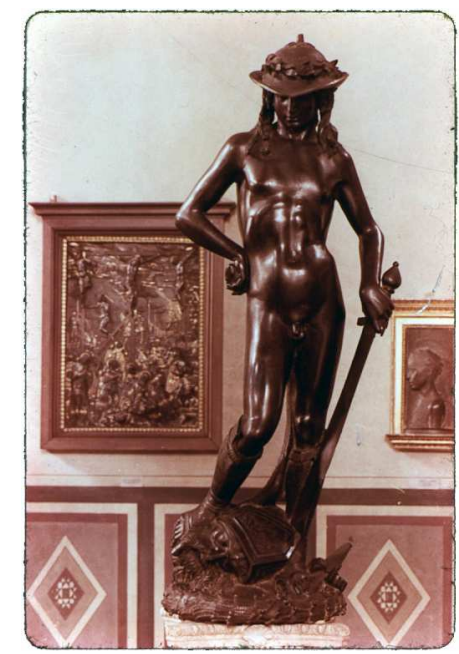

[RI_1-08]

A atitude mesma da figura recorda a arte clássica. A espada inclina-se do lado da perna estendida e há no corpo uma inflexão sutil. Notemos algo de feminino nos traços do rosto e mesmo no modelado do corpo. Esta espécie de sensualidade difusa, presente em grande parte da arte renascentista não deve surpreender nos.

O homem da renascença, centrado em si mesmo, libertando-se das contrições da igreja, concede grande apreço aos sentidos. Disso nos falam, por exemplo, esses Anjos Músicos de Agostino di Duccio ou nestas crianças de Donatello.

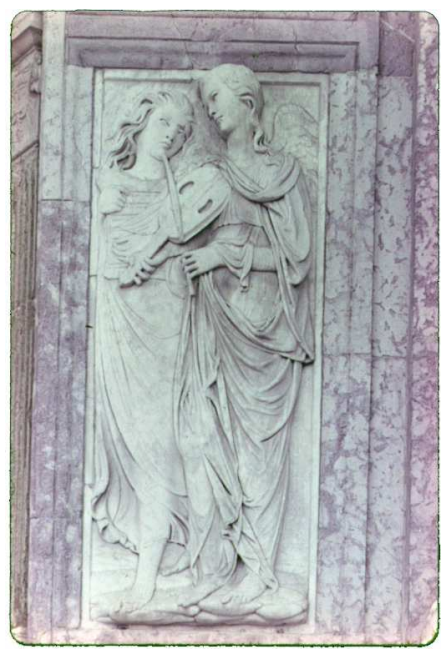

[RI_2-10]

[IMAGEM ORIGINAL EXTRAVIADA: Cantoria, de Donatello] ${ }^{\text {li }}$

A exuberância, a violência e os gritos desses pequenos seres, cujos corpos palpitam sob os véus transparentes e úmidos evocam os jogos de jovens faunos em algum sarcófago romano. 
Adão e Eva: o paraíso é evocado unicamente pela porta.

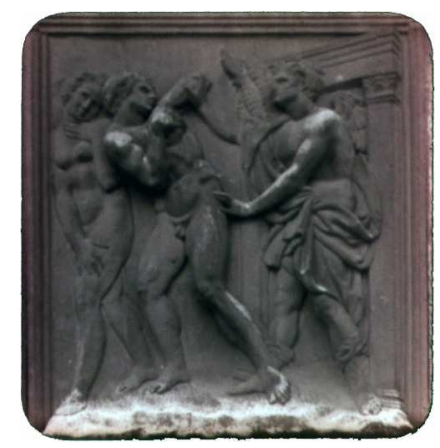

[RI_2-01]

Paisagem inexistente. Para Jacopo della Quércia, autor deste baixo relevo em mármore, contava unicamente como para tantos outros renascentistas, a figura humana.

Nicodemo: estátua em terracota de Niccolo della Arca.

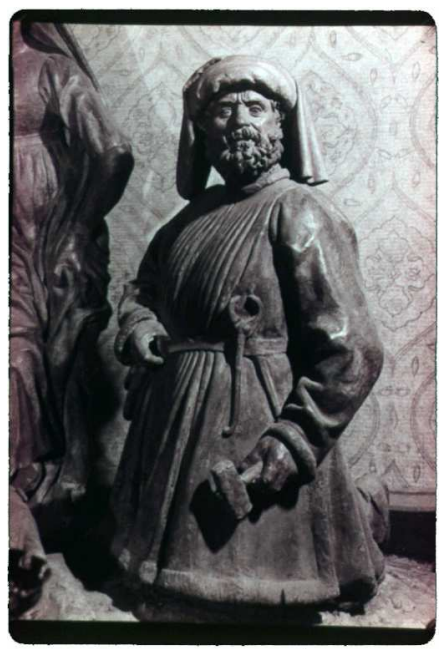

[RI_2-02]

Pertence a um conjunto maior, representando a crucificação. Um tema mitológico freqüente no Renascimento, que tanto se inspirava nos antigos.

Perseu e Andrômeda de Cellini.

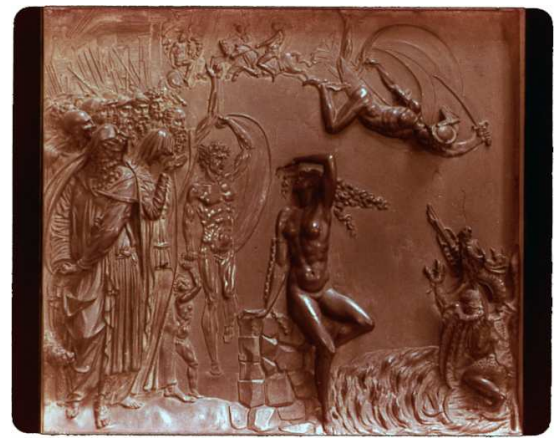

[RI_1-15] 
O assunto é tirado das Metamorfoses de Ovídio, o que não deixa de ser significativo. Mostra a ligação do artista renascentista com a tradição greco-romana.

Aqui, de Miguel Ângelo, um escravo.

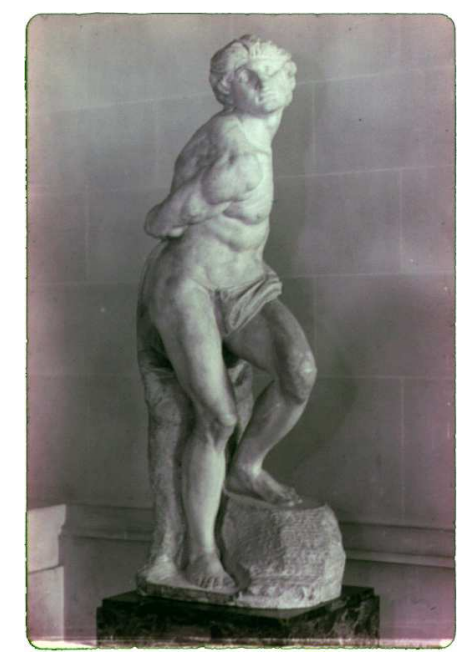

[RI_2-27]

$\mathrm{O}$ fato de ser uma obra inacabada tem chamado a atenção de alguns estudiosos. Acham alguns que o artista, desencorajado de alcançar o que pretendia, teria desistido. Outros, que o artista haveria receado, com o acabamento, quebrar o efeito. Muitas vezes, em Miguel Ângelo, o inacabado restringe-se a algumas partes da estátua _o_que, contrastando com algumas partes polidas, provoca uma estranha impressão.

Esta Pietà é uma das obras da última fase de Miguel Ângelo.

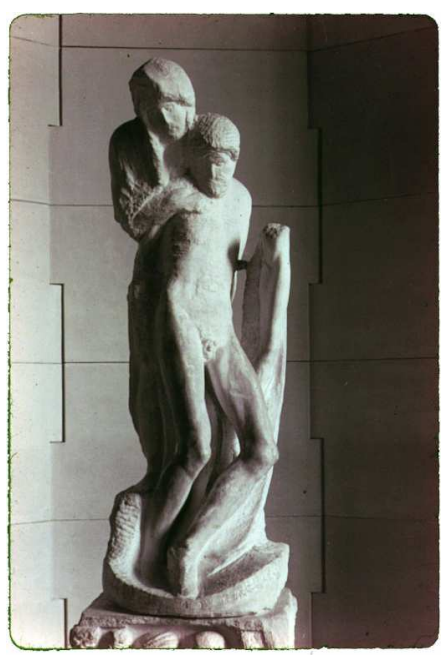

[RI_3 -30]

Aqui, toda preocupação com a beleza plástica desaparece neste tronco nodoso, no qual, no movimento dos dois corpos paralelos, como escreve Michel Gallet, desafia o equilíbrio. Ainda o mesmo crítico: "a Renascença, da qual Miguel Ângelo , havia em sua maturidade cumprido o ideal, parece aqui renunciar suas próprias normas."

Não apenas na estatuária, evidentemente, manifestou-se o espírito renascentista. O homem cercava-se de coisas aprazíveis. Ver esta Fonte das tartarugas de Roma. Interessante. 


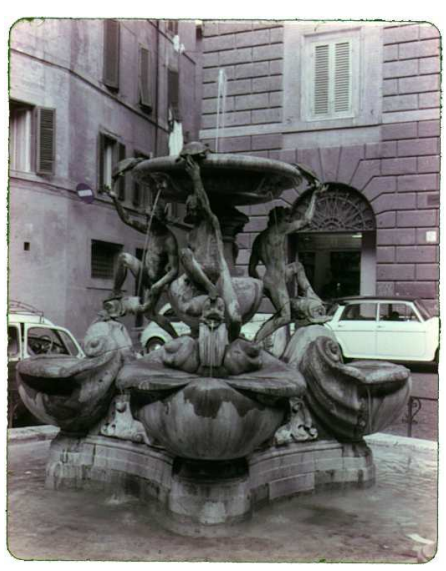

[RI_2-35]

As tartarugas que acabaram dando nome à fonte foram acrescentadas na época barroca.

Jardins da vila Lante em Bagnala.

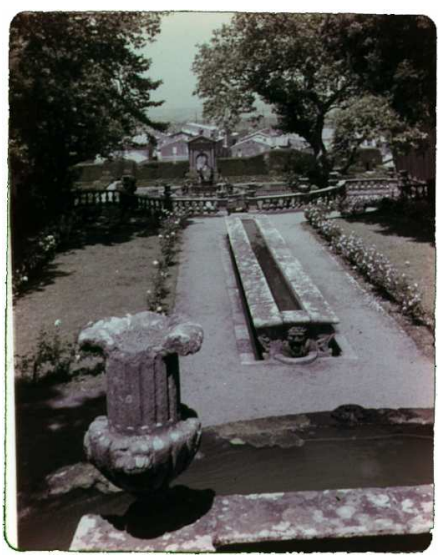

[RI_2-33]

Tentemos agora, mediante uma série de exemplos, dar uma idéia da arquitetura renascentista.

Cortile della Pigna, de Bramante, no Vaticano:

\section{[IMAGEM ORIGINAL EXTRAVIADA] $]^{\text {lii }}$}

A Pinha, que vemos ao centro, era um símbolo de imortalidade nas religiões orientais e provavelmente decorava um templo de Ísis.

Sacristia da igreja de Santo Espírito em Florença. Nem a severidade do Românico, nem o impulso do gótico para o alto. Uma arquitetura clara e cheia de harmonia. 


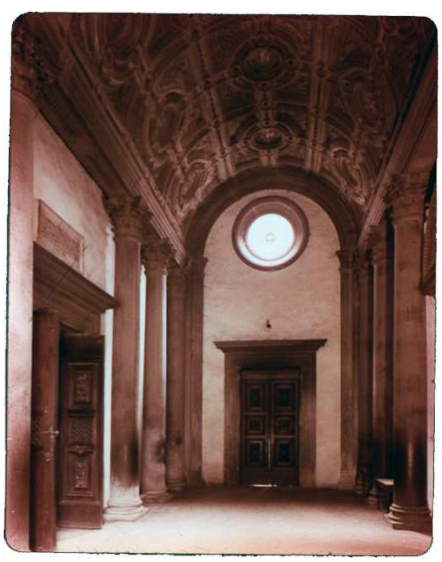

[RI_1-04]

A capela Pazzi de Brunelleschi, Florença.

\section{[IMAGEM ORIGINAL EXTRAVIADA] $]^{\text {liii }}$}

Villa Farnezzi de Vignoli: duas galerias onde altas arcadas alternam com aberturas mais modestas.

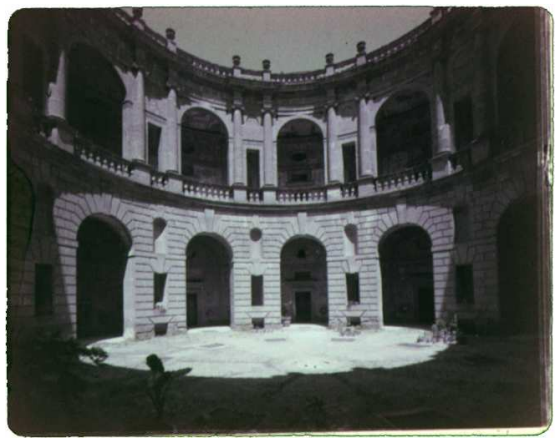

[RI_2 -32]

Fachada principal do palácio Farnezzi.

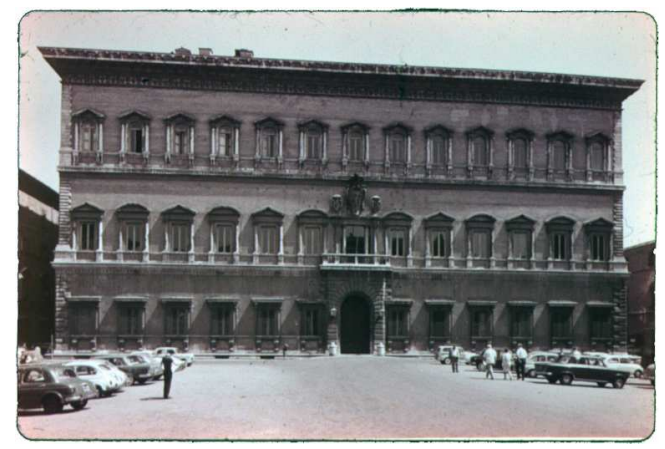

[RI_2 -31]

Iniciado na altura de 1515, por Antonio da Sangallo, o jovem. Esse edifício, note-se bem, é um dos exemplos clássicos da grande habitação humana no apogeu da renascença.

Pequeno templo de São Pedro em Roma. É uma das primeiras construções do arquiteto Bramante, após sua chegada em Roma. Inspira-se nos templos redondos da antiguidade. Um dos monumentos mais famosos do Renascimento e 
da arte ocidental: Cúpula e ápice de São Pedro em Roma. A cento e cinqüenta quilômetros de Roma, a cúpula de São Pedro é a primeira aparição que anuncia a cidade santa aos peregrinos.

\section{[IMAGEM ORIGINAL EXTRAVIADA] $]^{\text {liv }}$}

Templo Malatesta, em Rimini. Malatesta, príncipe da cidade, desejava um monumento que abrigassse as suas cinzas, as dos seus antepassados, as da sua amante e as dos artistas da sua corte. A parte superior ficou inconclusa.

\section{[IMAGEM ORIGINAL EXTRAVIADA $]^{\mathrm{lv}}$}

Esta igreja de Nossa Senhora da Consolação, em Todi, é atribuída a Bramante.

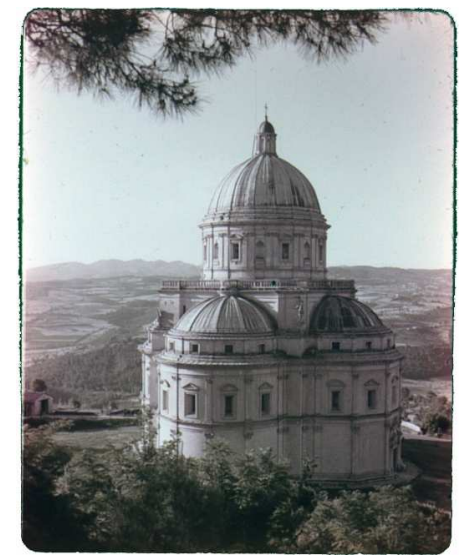

RI_2 -13

Contemporânea da igreja de São Pedro, de Roma, tem alguma semelhança com ela. A cúpula, principalmente, lembra a idealizada por Miguel Ângelo para o famoso templo romano.

Mas é principalmente através da pintura que o Renascimento marcaria a arte no mundo. Batalha de São Romano, de Paulo Ucello. Ucello pintou três painéis relativos a essa batalha.

\section{[IMAGEM ORIGINAL EXTRAVIADA $]^{\text {lvi }}$}

A chegada dos magos de Benozzi Ogazzi. Afresco existente em Florença. A minúcia do pincel faz pensar antes na miniatura que no afresco.

O Renascimento inicia a tradição dos grandes retratos profanos. De Bronzino, Eleonora de Toledo. O fundo azul, sutilmente modulado, limita a profundidade e concede a máxima importância à figura. 


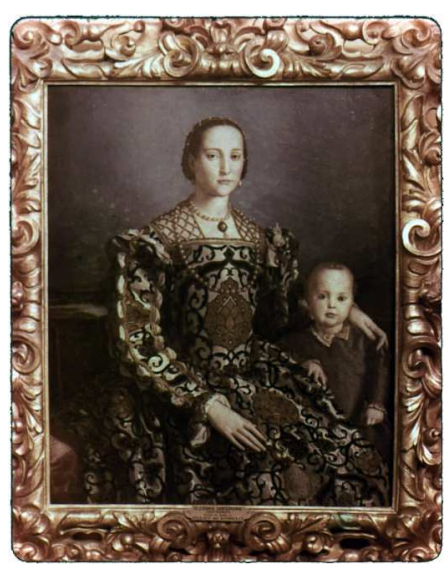

[RI_1-36]

De Andréa Del Castagno, que parece ter sido aluno de Ucello, autor da batalha que vimos a pouco, é este afresco. A figura solene e desafiadora imita o mármore e a rigidez das estátuas.

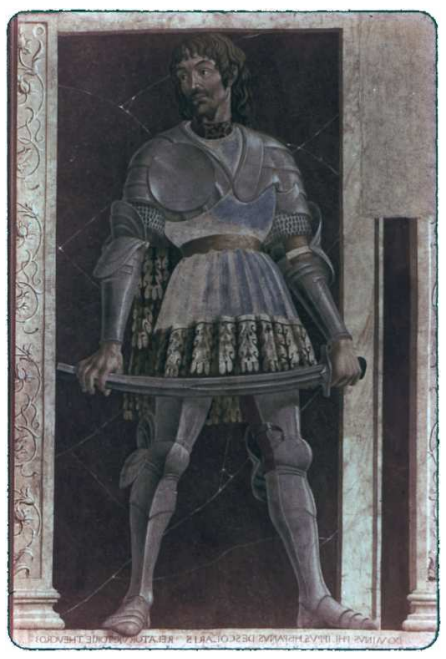

[RI_1-19]

Duque de Urbino e Piero de la Francesca: a grande objetividade do retrato ressalta a presença física do modelo. Ao fundo, uma paisagem.

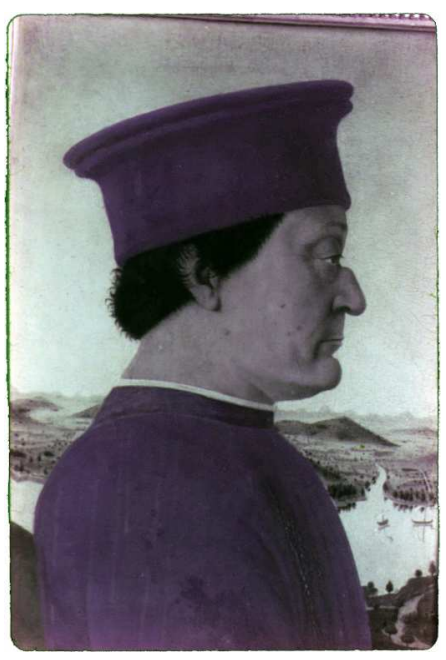

[RI_2 -04] 
O Papa Leão X, de Rafael. Grande maestria nos jogos com a cor vermelha. A textura dos tecidos dá uma ilusão perfeita da matéria.

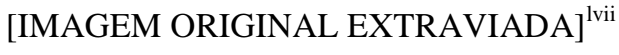

De Miguel Ângelo, aqui representado através de sua pintura, a sibila Délfica.

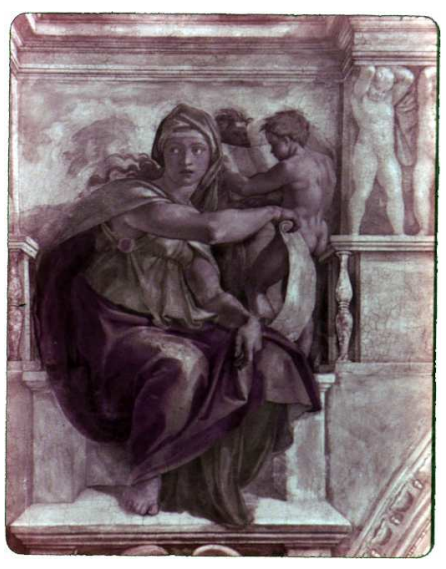

[RI_2 -25]

Detalhe da cúpula da capela Sistina, em Roma. Do mesmo conjunto, a criação de Adão.

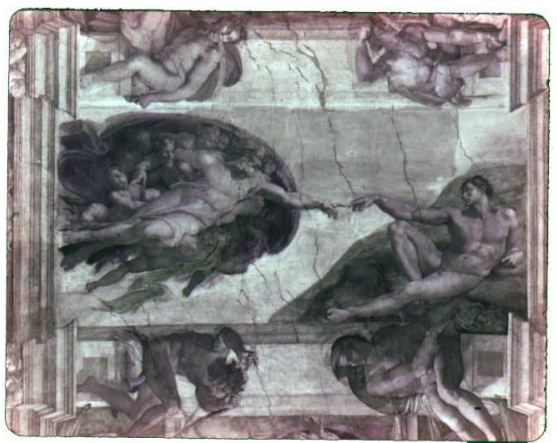

[RI_2 -24]

Não podemos deixar de assinalar que o barroco já se anuncia com bastante clareza na obra desse grande artista. Há algo de pagão nas suas figuras, mas a serenidade, a harmonia características da renascença parece esvair-se.

As núpcias de Alexandre, de Sodoma. A notar: o assunto colhido na antiguidade e a fusão das figuras com_motivos arquitetônicos. Há uma grande presença da arquitetura na arte renascentista.

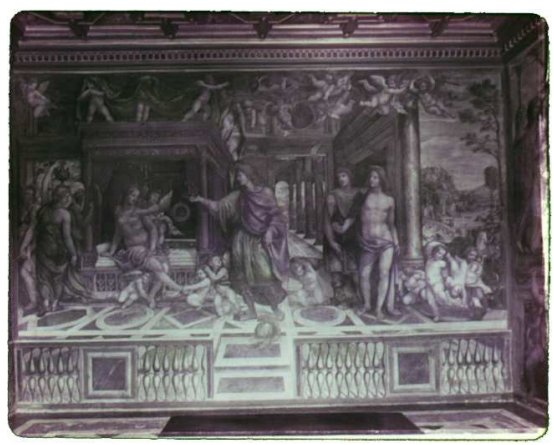

[RI_2 -22] 
As mesmas observações para este quadro de Rafael representando a Escola de Atenas. No centro: Platão e Aristóteles.

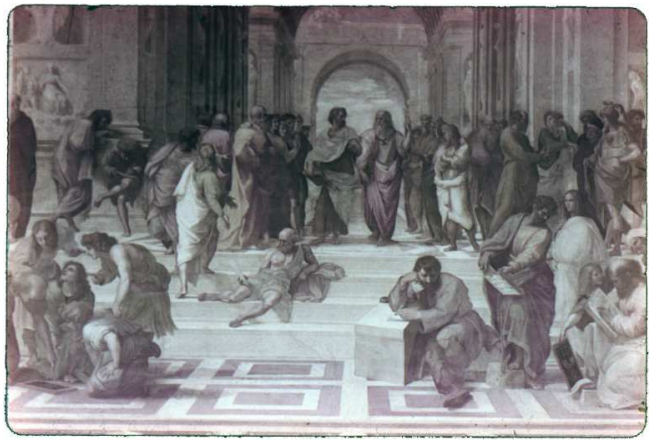

[RI_2 -20]

Um dos quadros mais famosos de toda a renascença: A Primavera, de Boticcelli. A deusa, ligeiramente inclinada, tem uma expressão distante, lânguida e enigmática como quase todas as mulheres de Boticcelli.

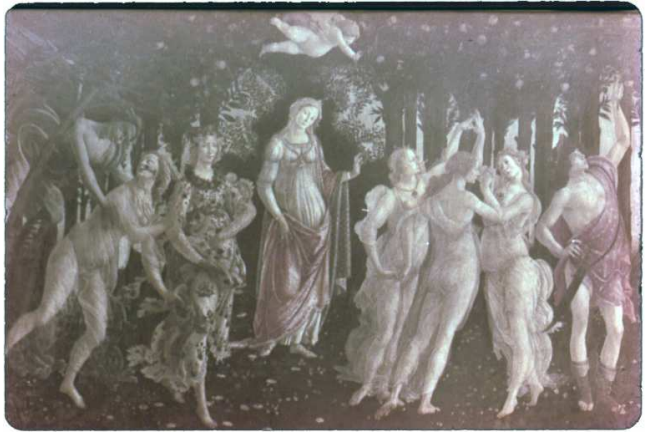

[RI_1-26]

Outro assunto mitológico: Galatéia, de Rafael.

\section{[IMAGEM ORIGINAL EXTRAVIADA] $]^{\text {viii }}$}

Ao lado dos retratos, são freqüentes na arte renascentista os registros históricos. Sixto IV concedendo a platina ao cargo de bibliotecário. Chamamos a atenção mais uma vez para o confronto figura humana arquitetura.

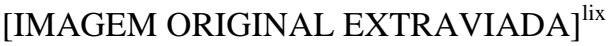

Mais uma representação de natureza histórica: disputa de Santa Catarina de Alexandria com os filósofos, diante do imperador Maximiano. 


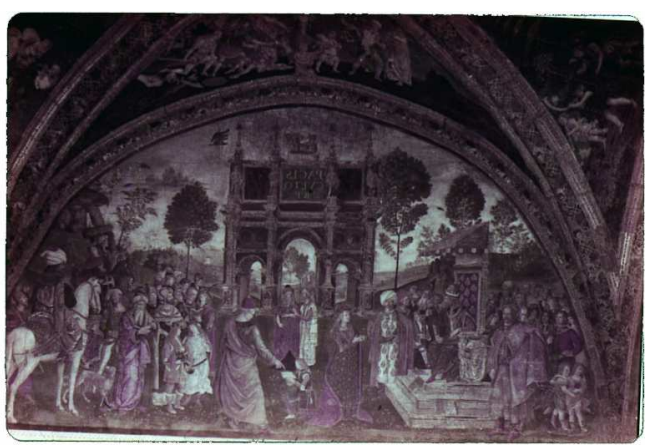

[RI_2-17]

Guirlandaio: funerais de Santa Fina. Composição simétrica, solene e de grande imponência.

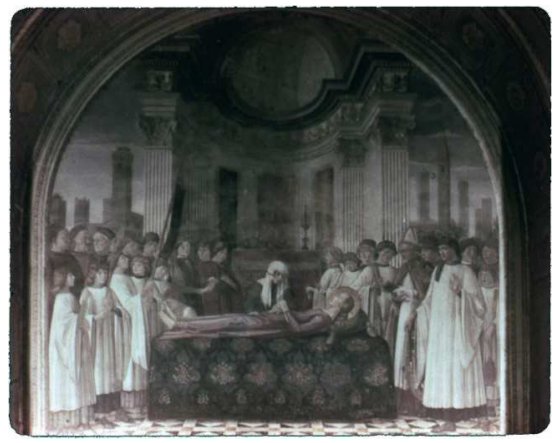

[RI_1-27]

Felipo Lipe: festim de Herodes. Lipe, segundo o hábito medieval, justapõe na mesma imagem dois episódios. Salomé à esquerda, obtém a cabeça de João. À direita, oferece-a a sua mãe.

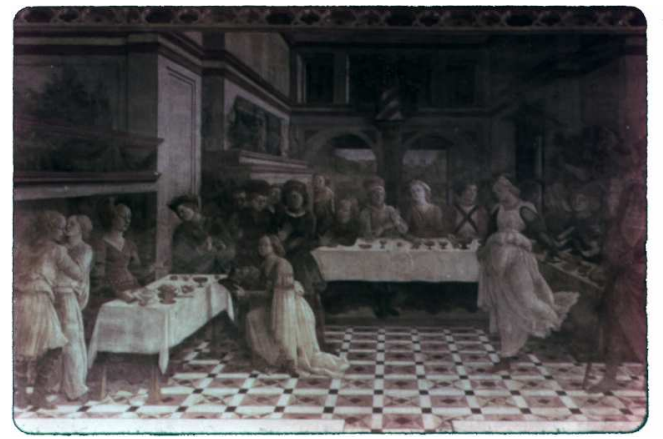

[RI_1-24]

Voltamos a Botticelli, com um quadro não muito conhecido: Juventude de Moisés.

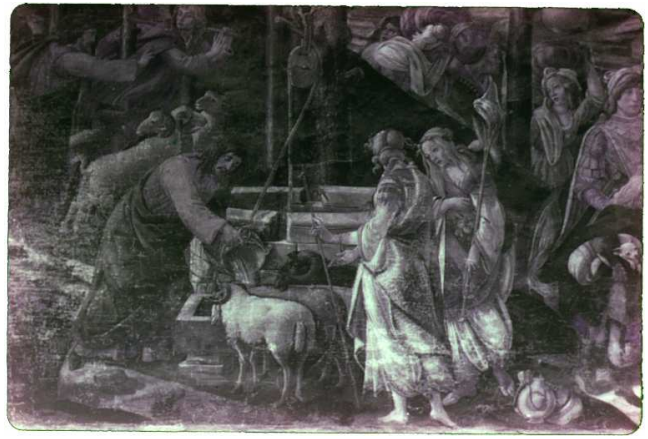


Outro assunto bíblico: Viagem de Tobias, quadro de Polaiolo. Grande parte do interesse do quadro está na paisagem ao fundo.

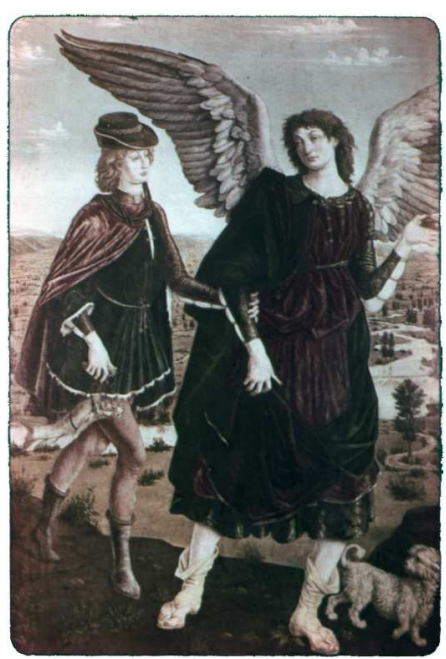

[RI_1 -25]

Obra de grande sobriedade e força: Adão e Eva, de Masaccio. O homem, ao contrário da mulher, manifesta uma tristeza silenciosa e secreta. Quadro altamente estranho, com algo de selvagem:

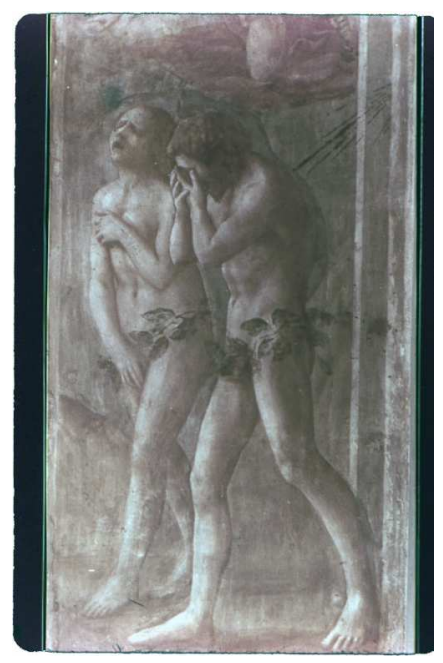

[RI_1 -17]

A Ressurreição da Carne, de Signorelli. Esqueletos de corpos revestidos de carne regressam do seio da terra. 


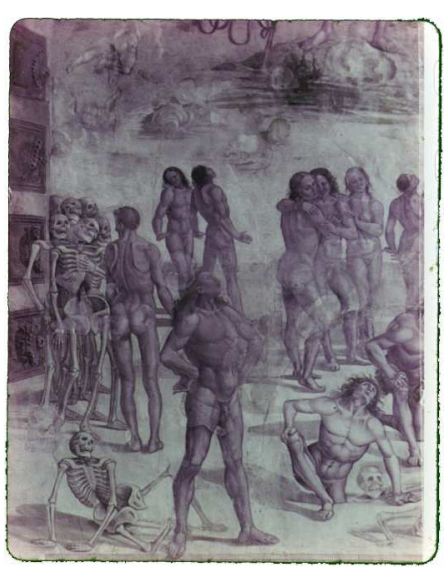

[RI_2 -12]

Bem diversa, esta ressurreição de Cristo, de. Piero Della Francesca.

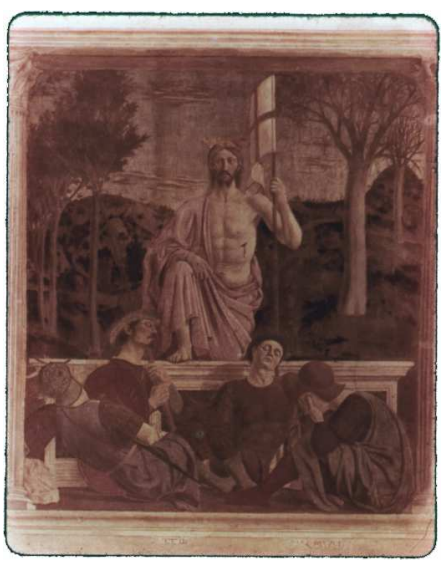

[RI_1 -23]

Deposição da cruz, de Pontormo, Igreja de Santa Felicita, de Florença. Um desenho atormentado que anuncia o barroco.

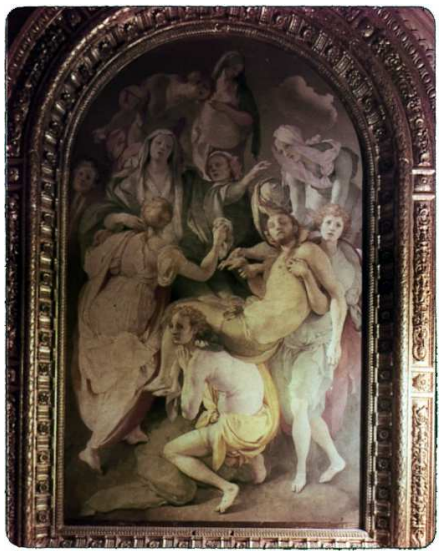

[RI_1 -35]

Verrocchio: batismo de Cristo. Doce e sóbria harmonia emana destes corpos acéticos pintados com grande precisão. É interessante notar como mesmo tratando assuntos religiosos, algo de muito humano insinua-se na arte renascentista. 


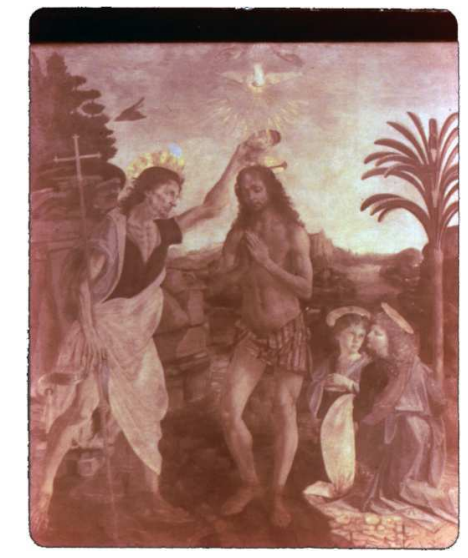

[RI_1 -30]

Repouso da Santa Família, de André Del Sarto:

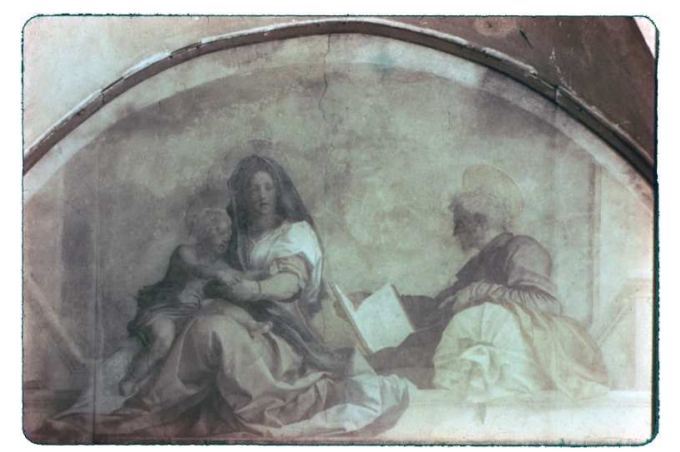

[RI_1 -34]

A mesma observação para esta Santa família, de Miguel Ângelo.

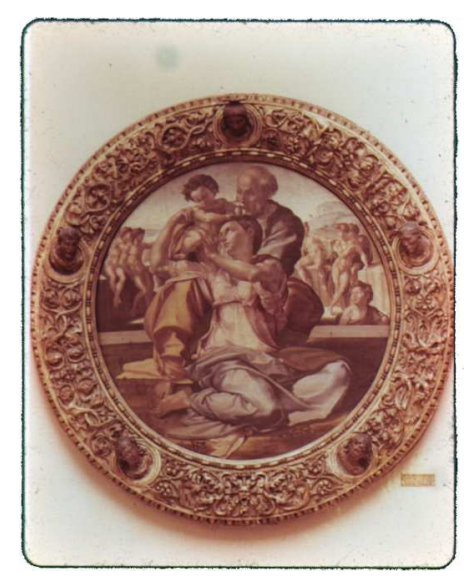

[RI_1 -32]

Obsessão arquitetural manifesta-se-se mais uma vez nesta natividade de Perugino: 


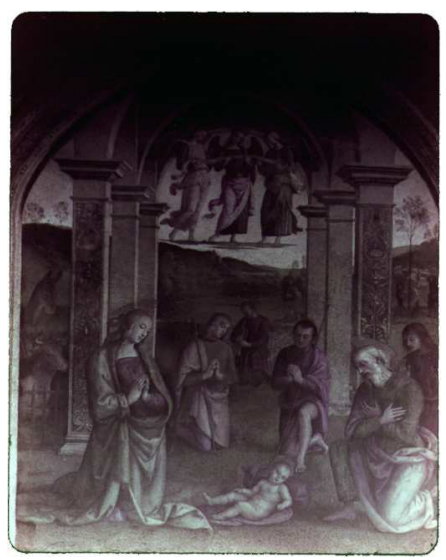

[RI_2 -11]

Nessa natividade, de Giorgio Martini.

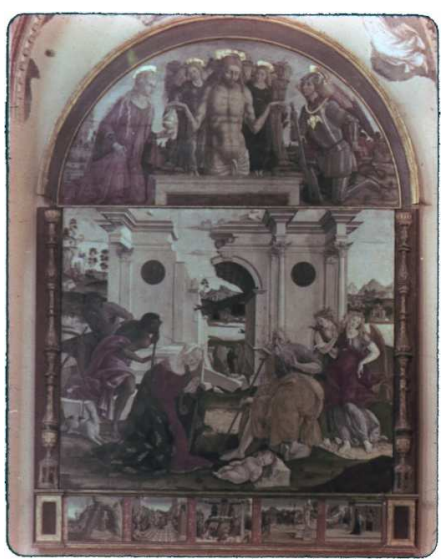

[RI_1 -29]

E ainda, nesta virgem e santos de Veneziano.

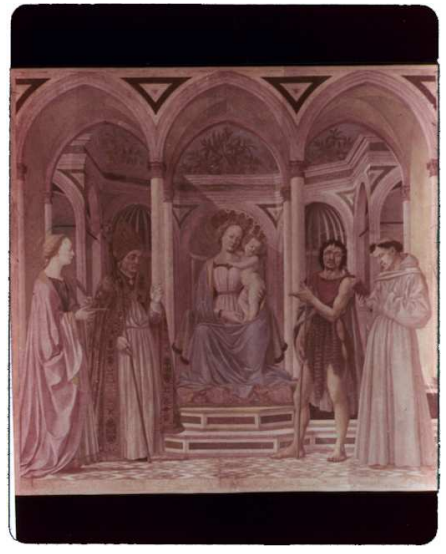

[RI_1 -20]

Arquitetura, signo da habitação humana, desloca as figuras sagradas do espaço mítico, inserindo-as, de certo modo, na escala terrena.

Madonna de São Simioni, de Barocci: 


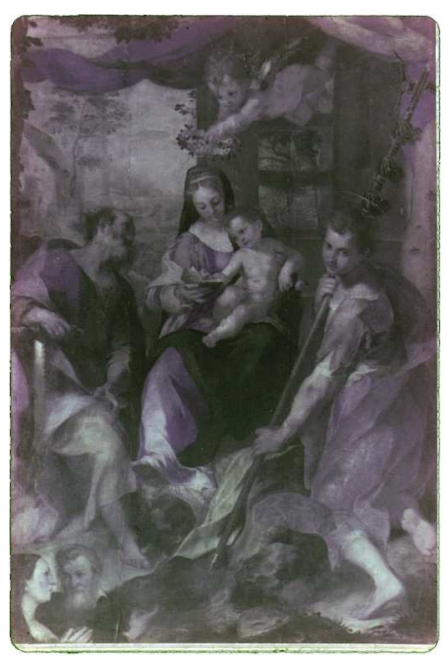

[RI_2 -08]

Madona della Candeletta, de Carlo Crivelli, Pinacoteca de Brera, em Milão: preocupação decorativa um tanto superficial.

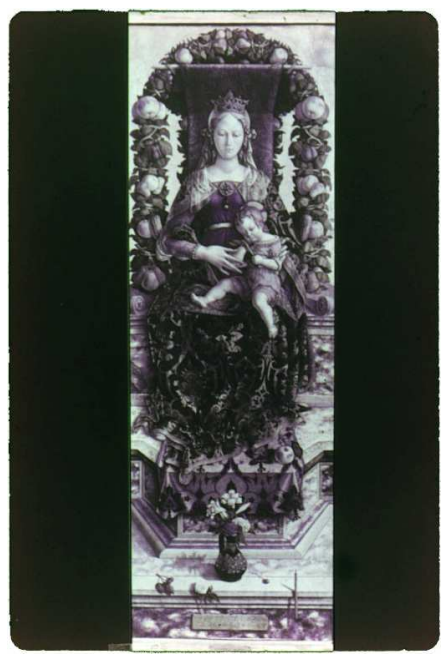

[RI_2 -09]

A virgem e o filho, de Baldovinetti: indiscutível a beleza plástica. Mas estamos longe da severidade e da transcendência que encontramos na arte religiosa das épocas gótica e românica.

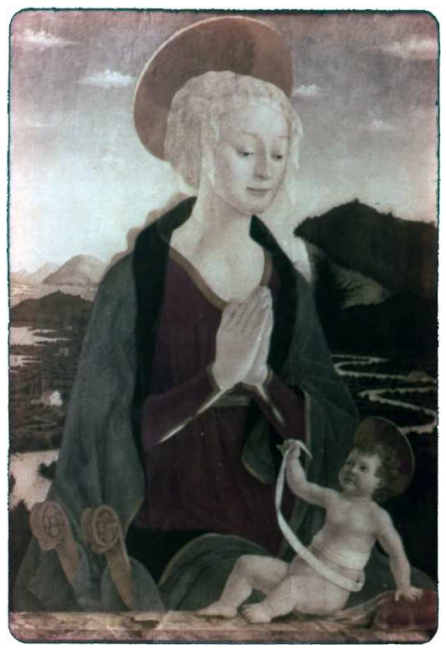


Virgem, de Rafael: a mesma beleza acentuadamente carnal que por toda parte notamos no Renascimento. Ao mesmo tempo, serenidade e harmonia.

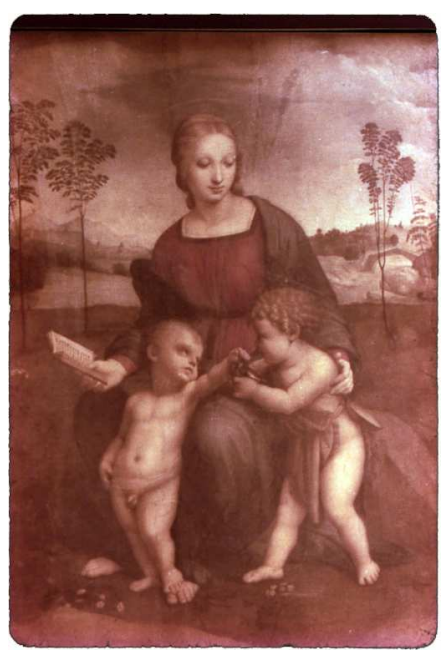

[RI_1-33]

Sant'Anna e a Virgem, do grande mestre Leonardo da Vinci. Especialistas afirmam que a criança e o cordeiro teriam sido pintados por um colaborador e não por Leonardo.

\section{[IMAGEM ORIGINAL EXTRAVIADA $]^{\mathrm{lx}}$}

Outro grande nome do renascimento: Fra Angelico, aqui representado pelo que alguns consideram a sua obra prima: Anunciação. Sem perda da transcendência, muitos característicos do renascimento aí se encontram. A harmonia, a obsessão arquitetural, a atração pelo luxo. Mesmo a languidez de Boticcelli parece aí anunciada. Ao fundo, um anjo expulsa o primeiro casal humano do paraíso terrestre. Estabelece-se assim, no quadro, um liame espiritual, entre a queda de Adão e a vinda de Cristo, redentor do gênero humano.

\section{[IMAGEM ORIGINAL EXTRAVIADA] $]^{1 \times i}$}

As notas para esta apresentação foram baseadas nos volumes um e dois de La Renaissance en Italie de Bernard de Motgolfier e Michel Gallet ${ }^{1 x i i}$. Como fundo musical, utilizamos os músicos da Provença, instrumentos antigos, os músicos troveiros e trovadores.

Muito obrigado. 
${ }^{\mathrm{i}}$ Imagem de referência:

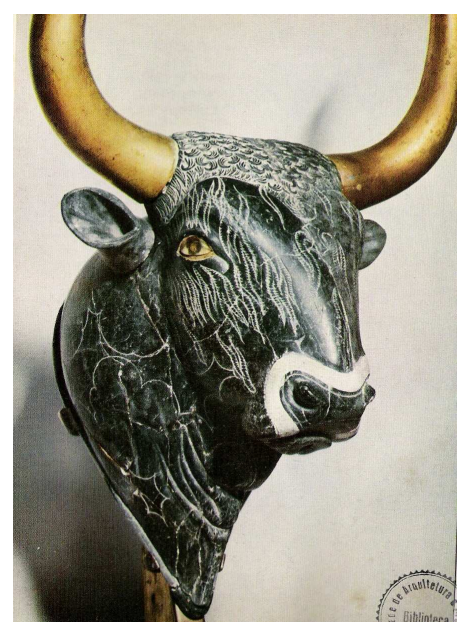

MATZ (1962, PLATE 28)

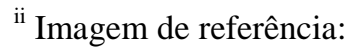

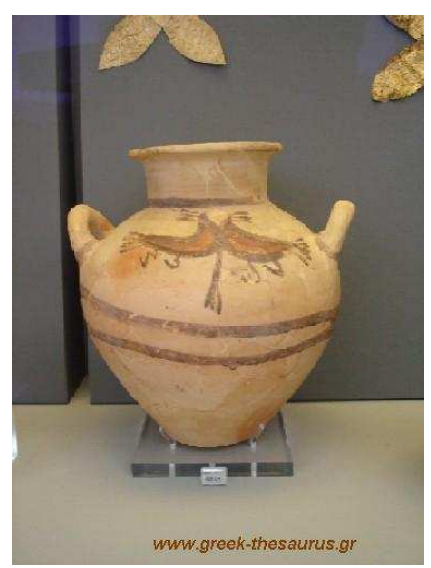

http://www.greek-thesaurus.gr/images/p4/clay_jar.JPG

iii Imagem de referência: 


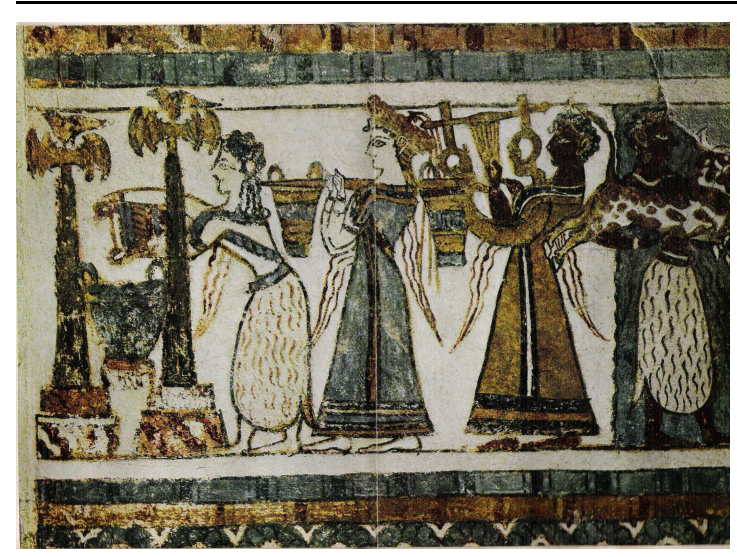

MATZ (1962, p 119)

${ }^{\text {iv }}$ Imagem de referência:

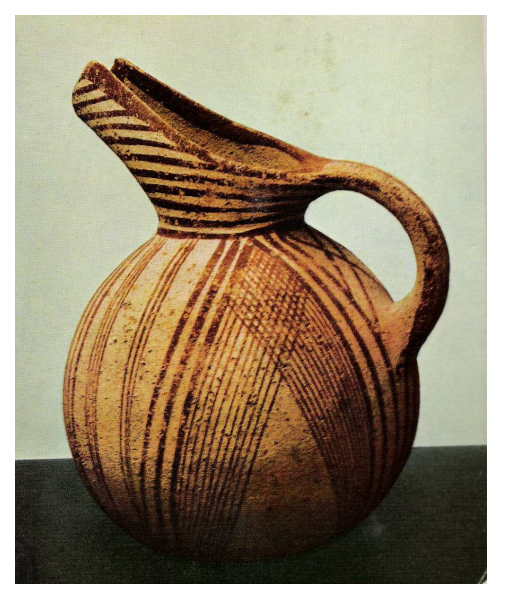

MATZ (1962, PLATE 8)

v Imagem de referência:

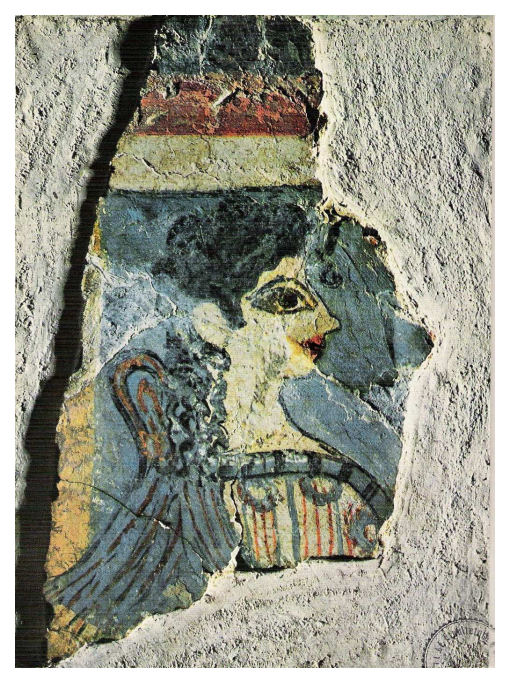

MATZ (1962, PLATE 26)

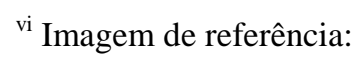




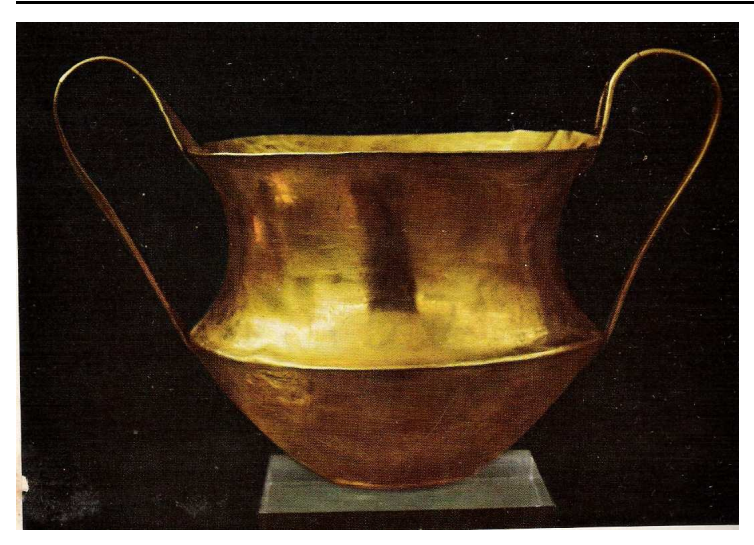

MATZ (1962, PLATE 45)

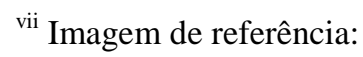

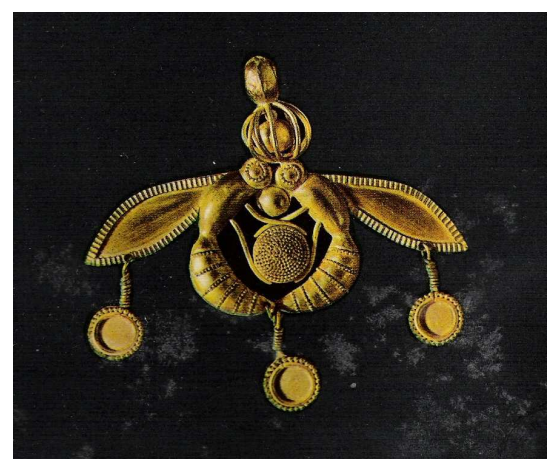

MATZ (1962, PLATE 33)

viii Imagem de referência:

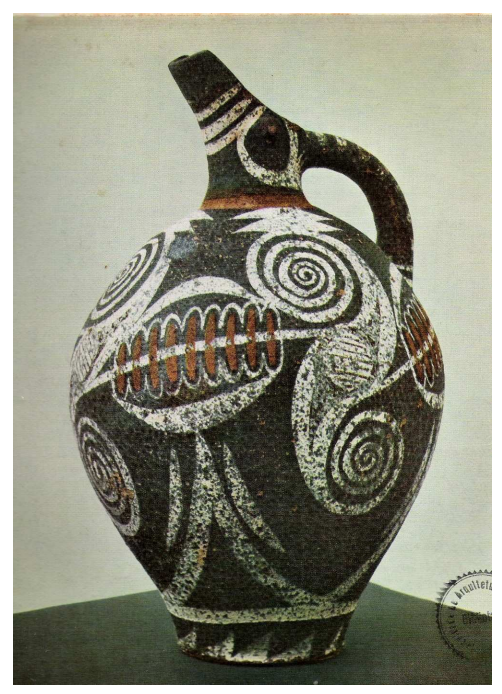

MATZ (1962, PLATE 35)

${ }^{\text {ix }}$ Imagem de referência: 


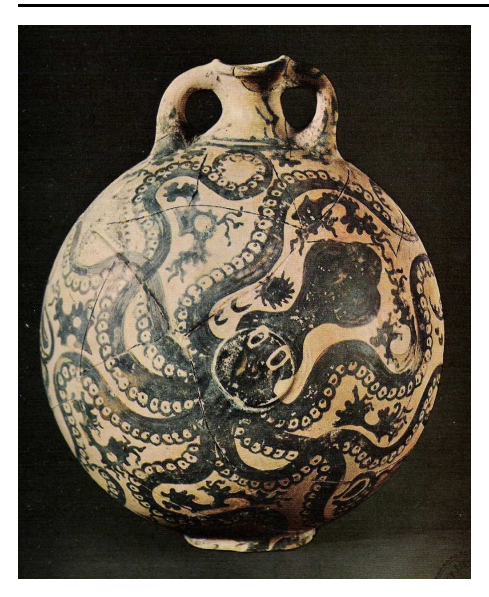

MATZ (1962, PLATE 38)

${ }^{\mathrm{x}}$ Imagem de referência:

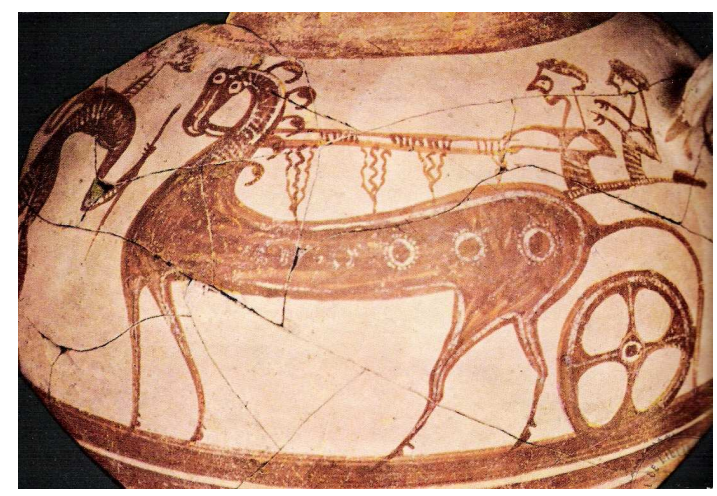

MATZ (1962, PLATE 56)

${ }^{\mathrm{xi}}$ Imagem de referência:

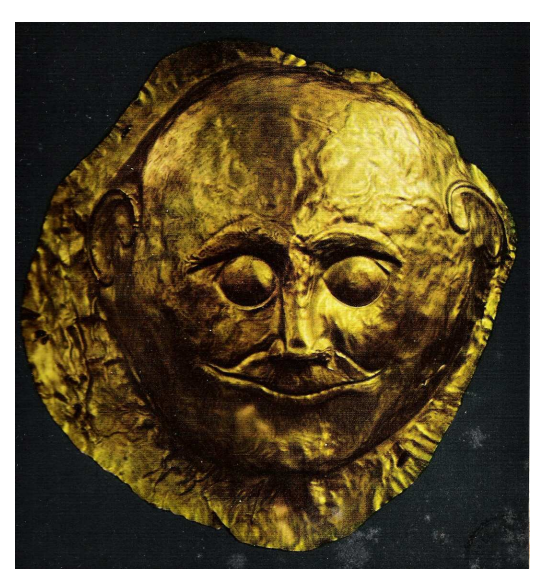

MATZ (1962, PLATE 40)

xii Imagem de referência: 


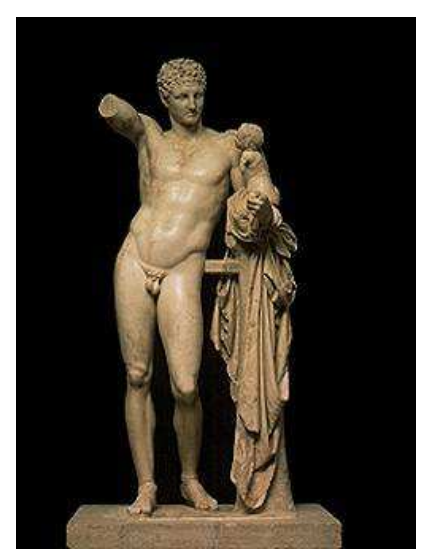

http://pt.wikipedia.org/wiki/Escultura_da_Gr\%C3\%A9cia_Antiga

$22 / 11 / 2011$

xiii Imagem de referência:

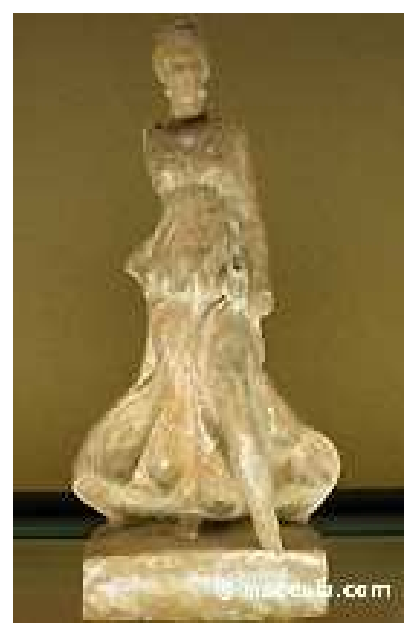

http://www.insecula.com/oeuvre/O0010490.html

22/11/2011

${ }^{\text {xiv }}$ Imagem de referência:

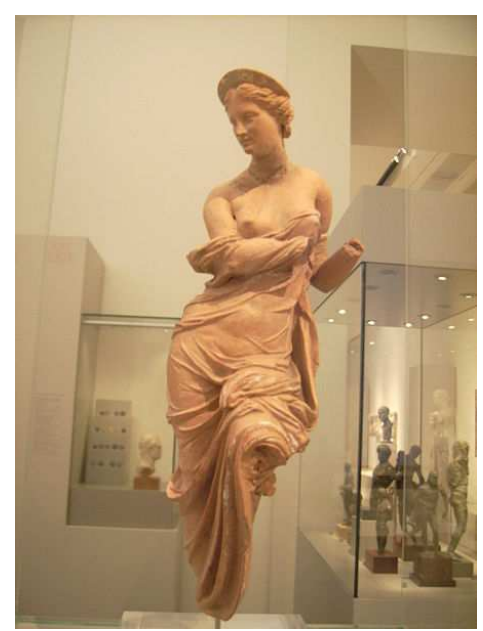

http://de.wikipedia.org/wiki/Tonfigur_der_Aphrodite_(Antikensammlung_Berlin,_Inventarnummer_31272) $22 / 11 / 2011$

${ }^{\mathrm{xv}}$ Imagem de referência: 


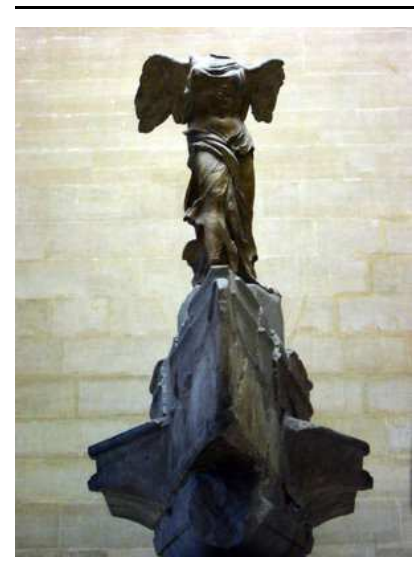

http://blog.photos-libres.fr/2006/05/02/la-victoire-de-samothrace/

$22 / 11 / 2011$

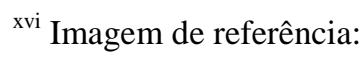

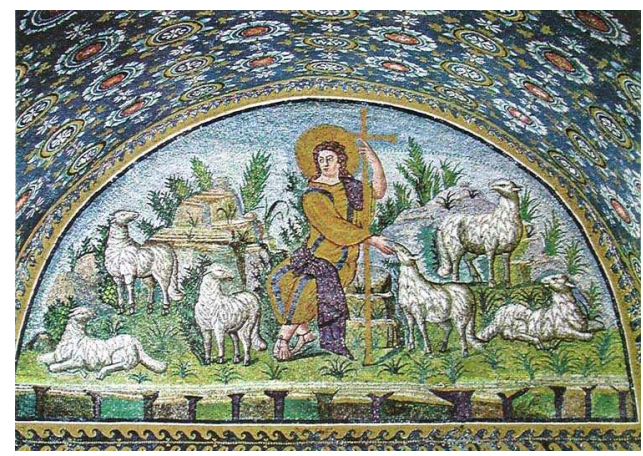

http://pt.wikipedia.org/wiki/Mausol\%C3\%A9u_de_Gala_Plac\%C3\%ADdia $22 / 11 / 2011$

xvii Imagem de referência:

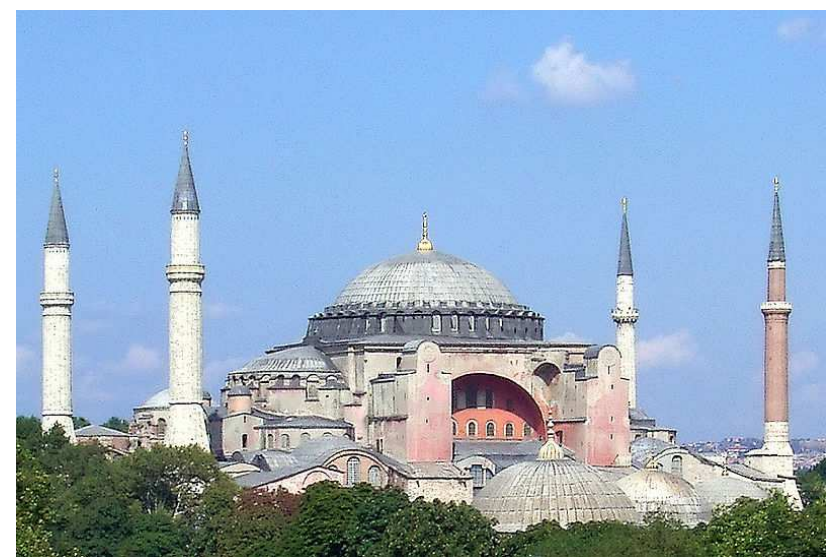

http://pt.wikipedia.org/wiki/Bas\%C3\%ADlica_de_Santa_Sofia 22/11/2011

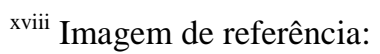




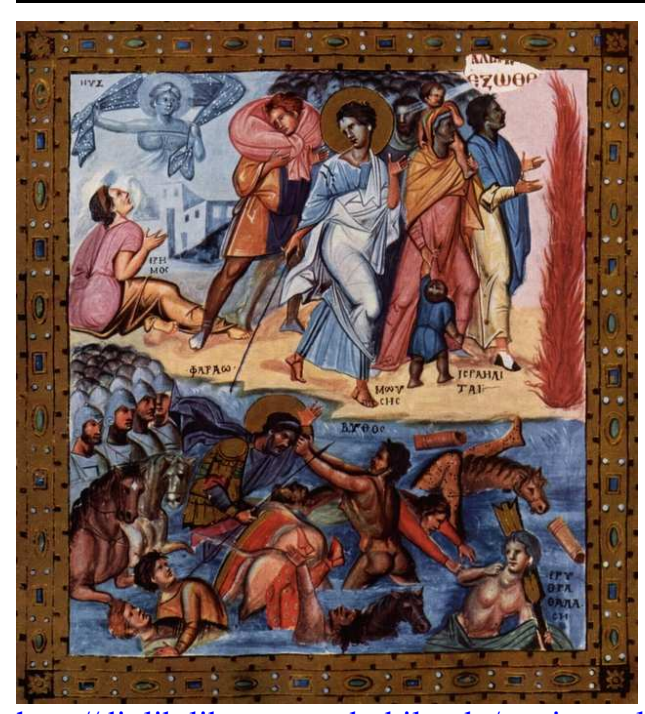

http://diglib.library.vanderbilt.edu/act-imagelink.pl?RC $=46583$ 22/11/2011

${ }^{\text {xix }}$ Imagem de referência:

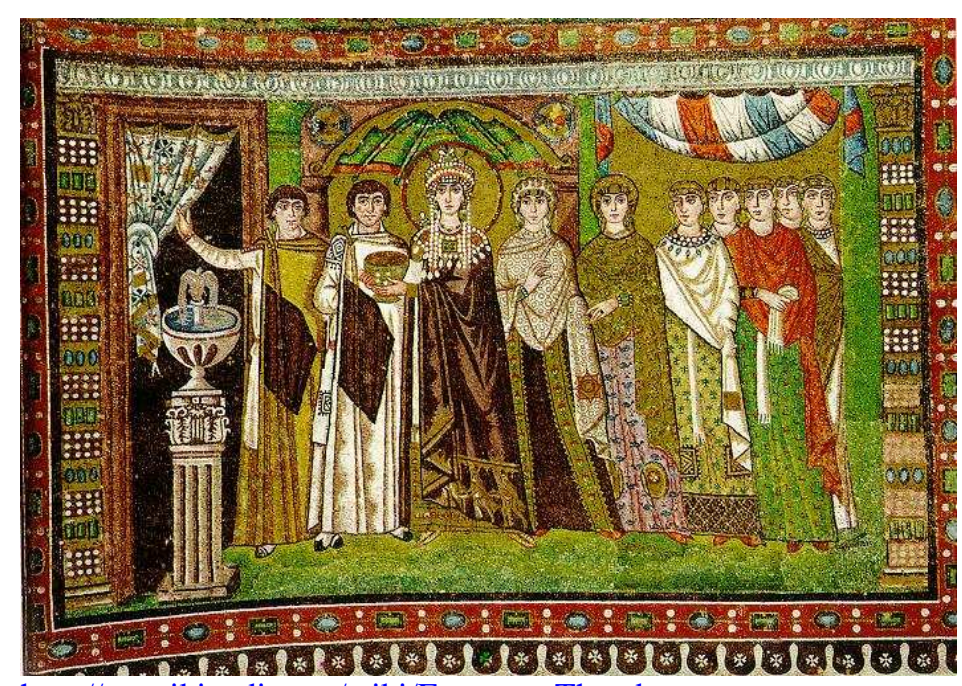

http://en.wikipedia.org/wiki/Empress_Theodora

$22 / 11 / 2011$

${ }^{\mathrm{xx}}$ Imagem de referência: 


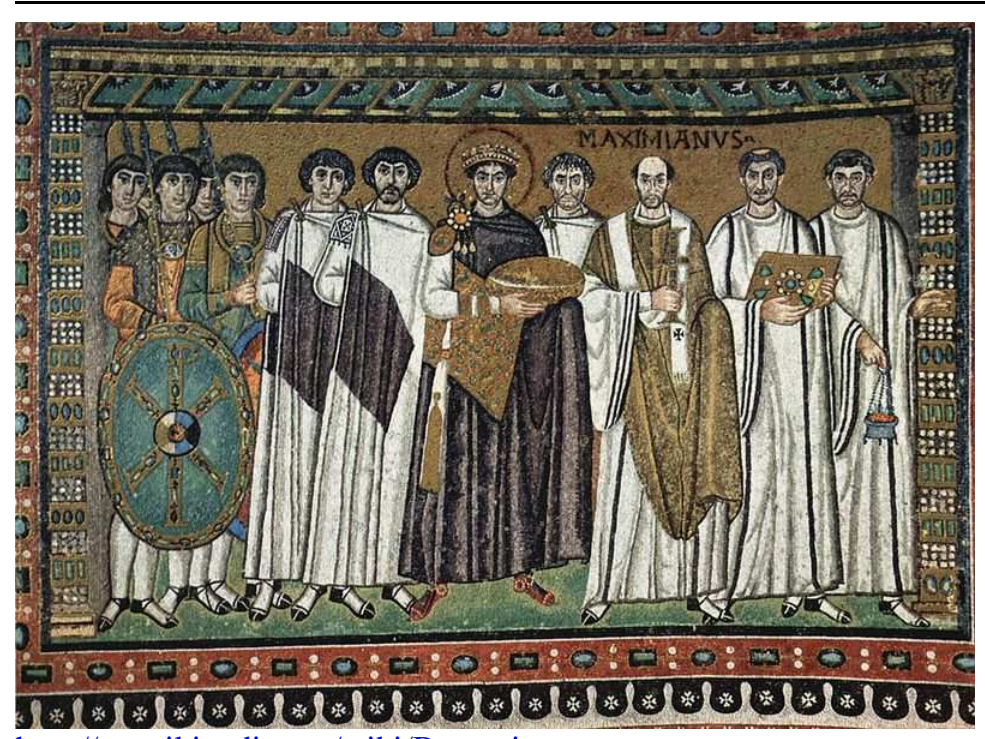

http://en.wikipedia.org/wiki/Byzantine art

22/11/2011

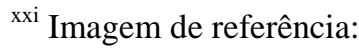

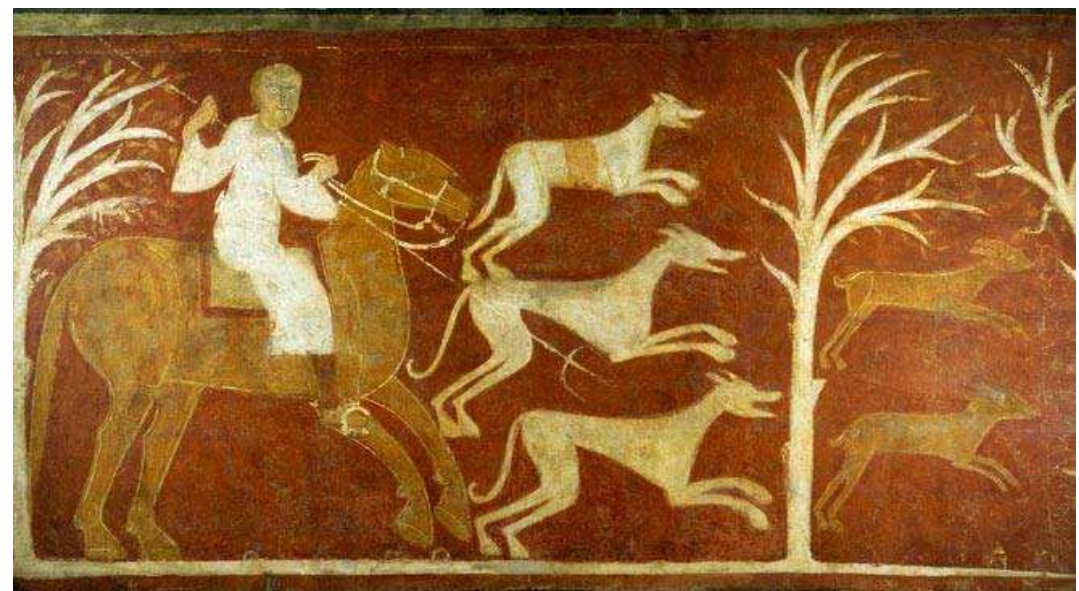

http://www.spainisculture.com/en/obras_de excelencia/caceria_de liebres.html $22 / 11 / 2011$

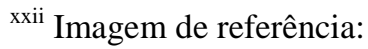

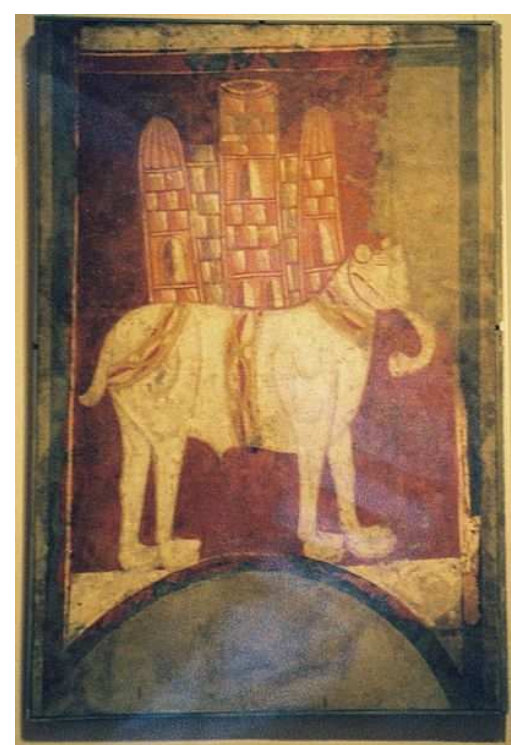

http://en.wikipedia.org/wiki/War_elephant 22/11/2011 
xxiii Imagem de referência:

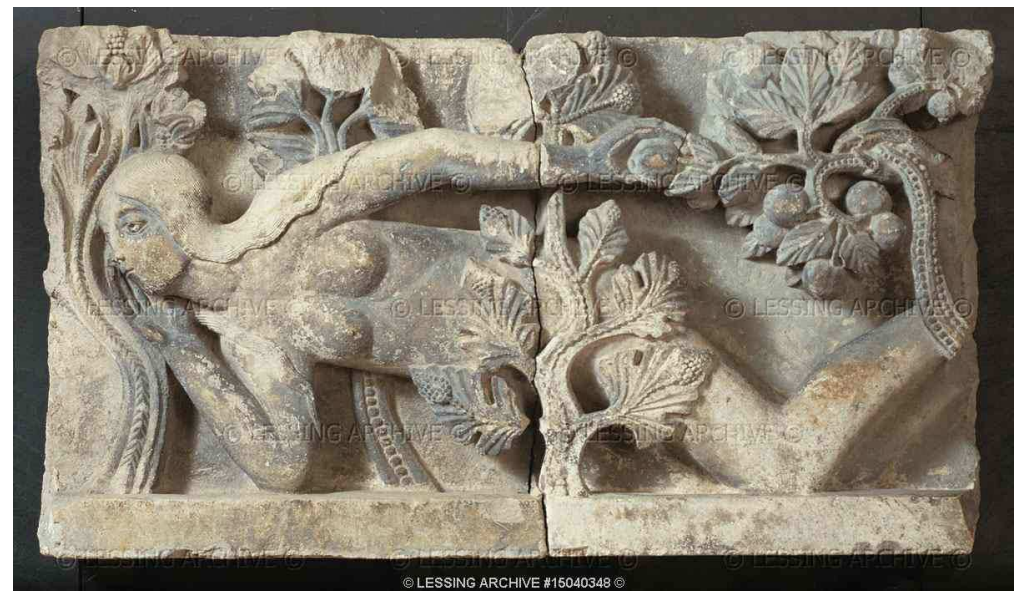

http://www.lessing-photo.com/dispimg.asp? $\mathrm{i}=15040348+\& \mathrm{cr}=4 \& \mathrm{cl}=1$ $22 / 11 / 2011$

${ }^{\text {xxiv }}$ Imagem de referência:

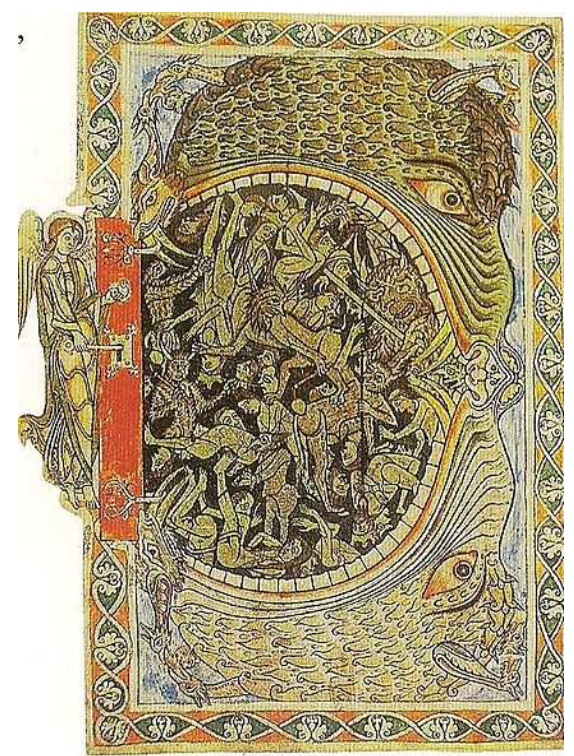

http://en.wikipedia.org/wiki/Winchester Psalter $22 / 11 / 2011$

${ }^{\mathrm{xxv}}$ Imagem de referência: 


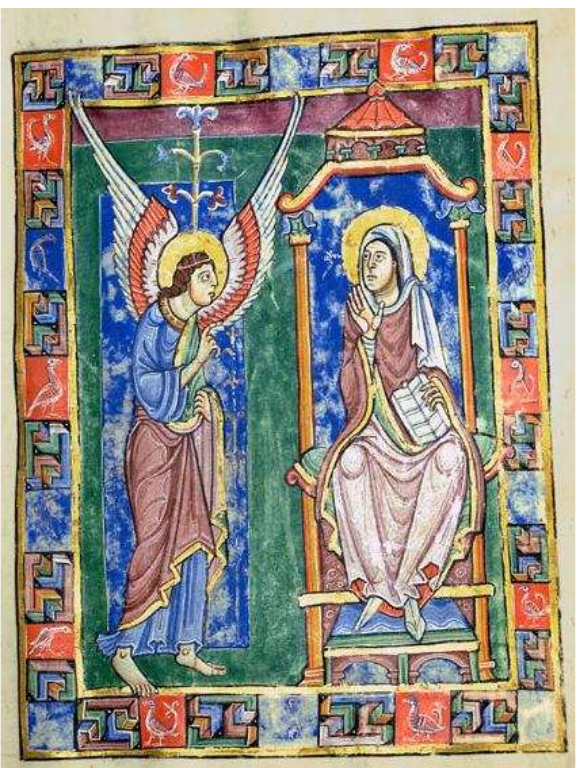

http://www.abdn.ac.uk/ lib399/english/commentary/page019.shtml 22/11/2011

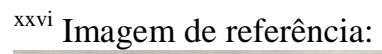

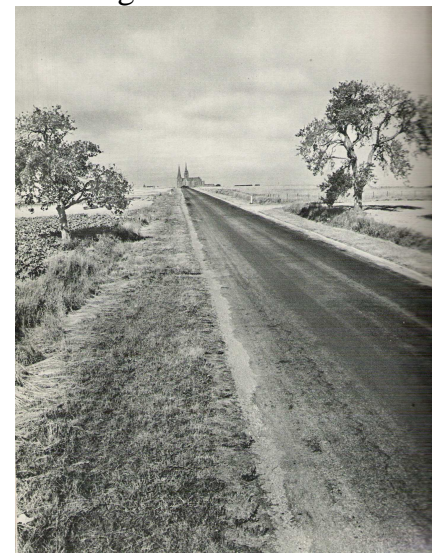

DELAPORTE (1957)

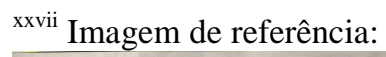

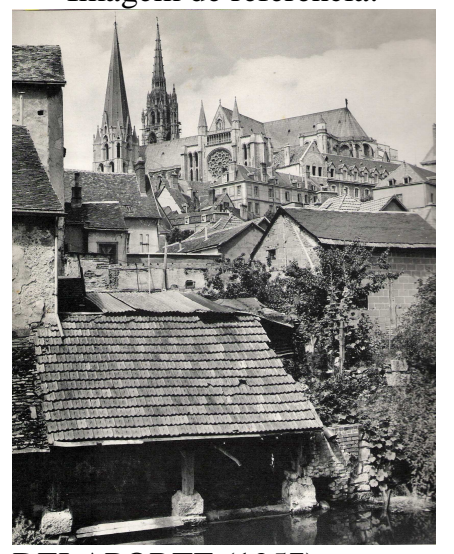

DELAPORTE (1957)

xxviii Imagem de referência: 


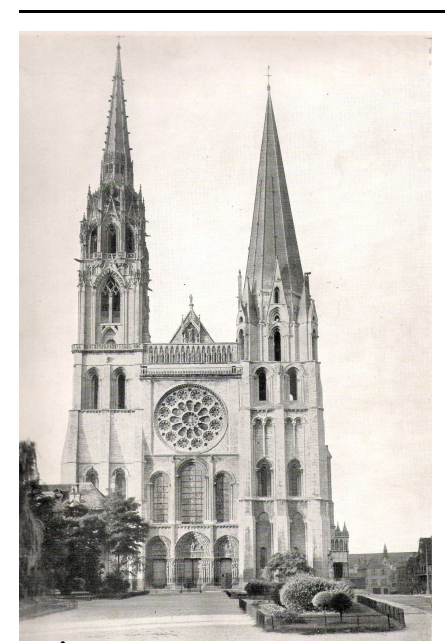

MÂLE (1948)

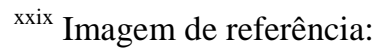

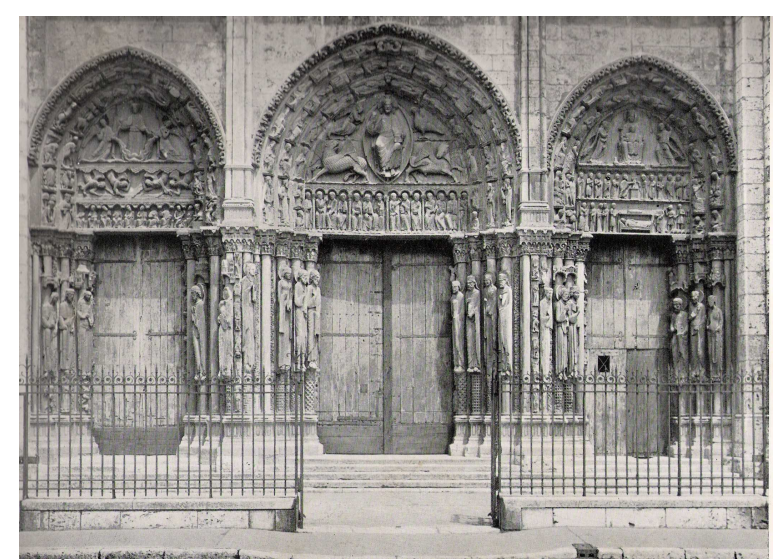

MÂLE (1948, p. II)

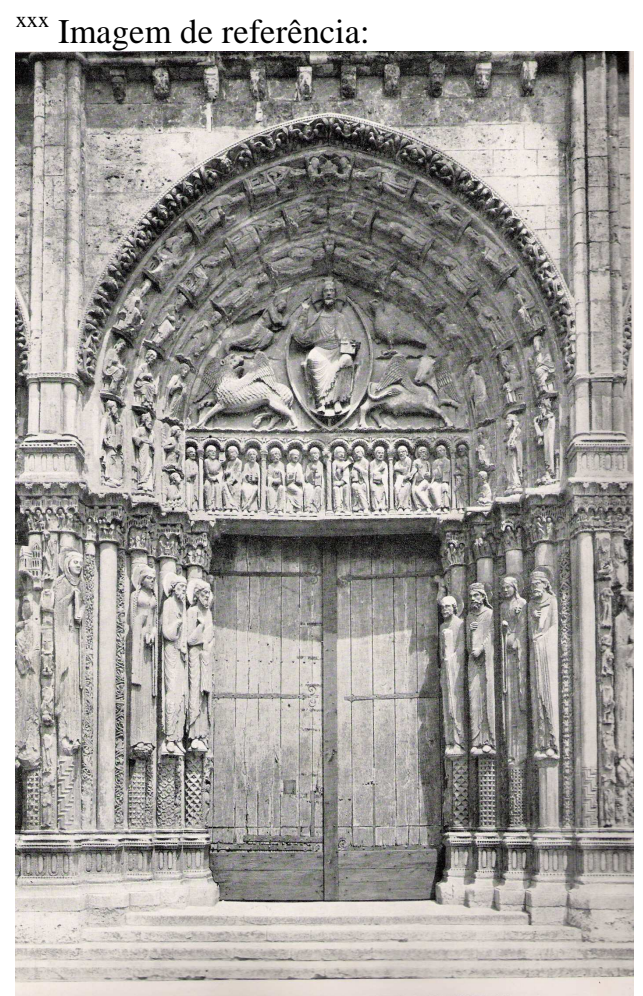

MÂLE (1948, p. 18)

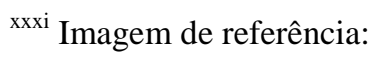




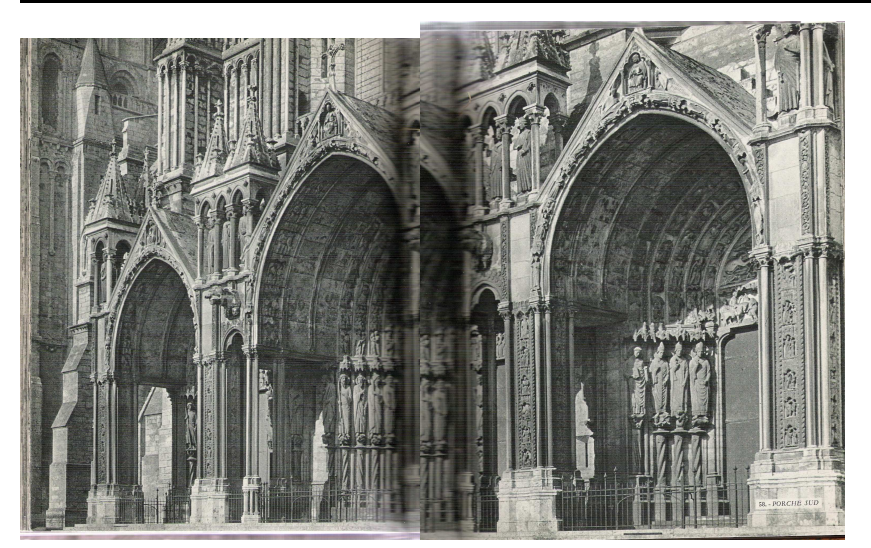

AUBERT (1952, p. 58)

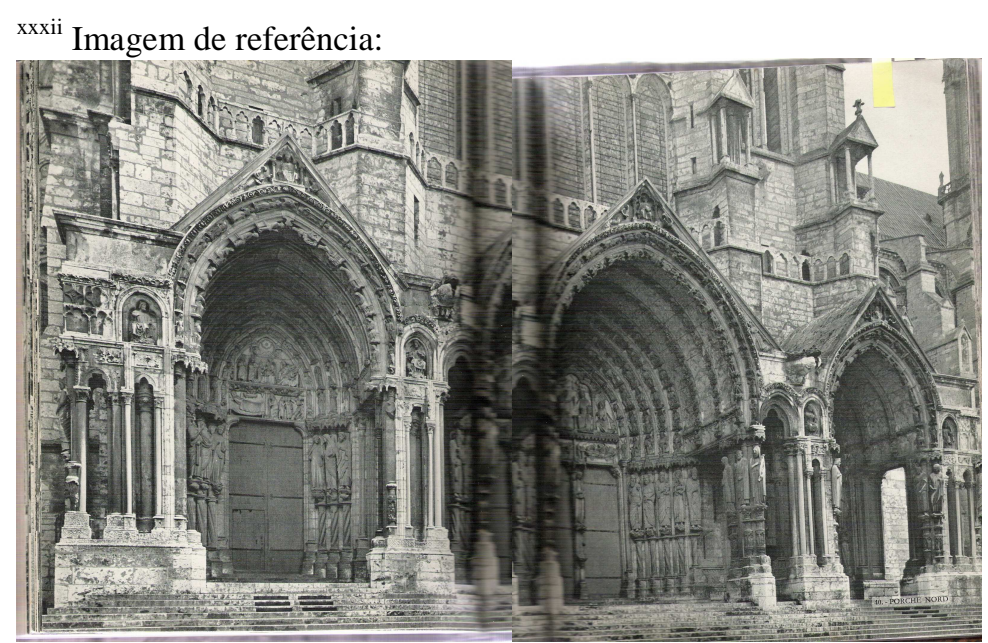

AUBERT (1952, p. 40)

xxxiii Imagens de referência:
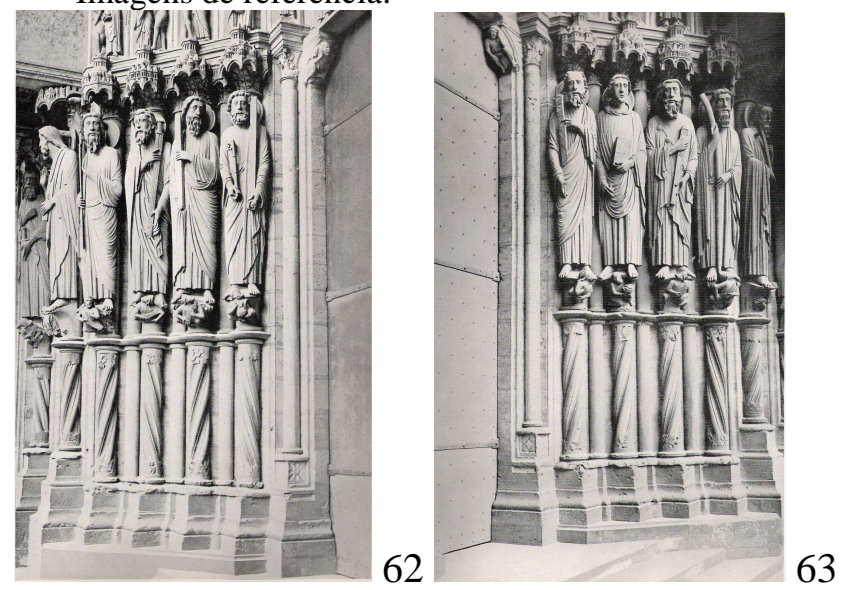

MÂLE (1948, 62-63)

${ }^{\text {xxxiv }}$ Imagens de referência: 

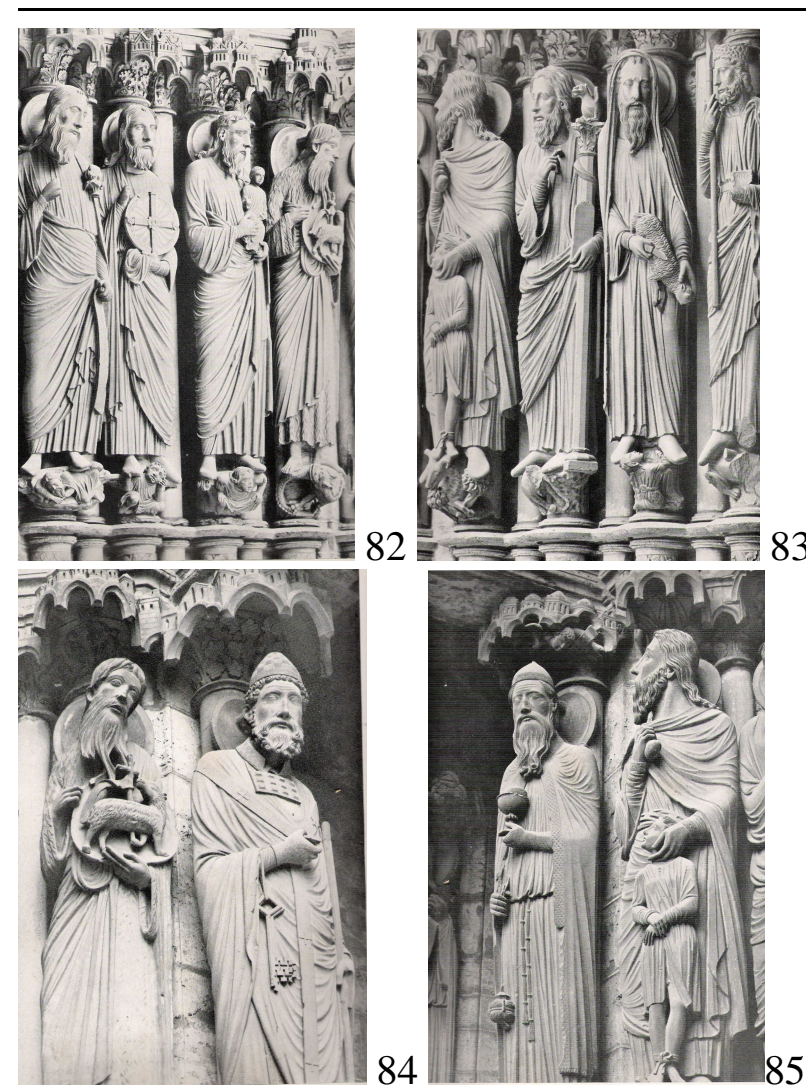

MÂLE (1948, 82-85)

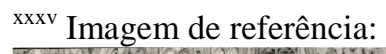

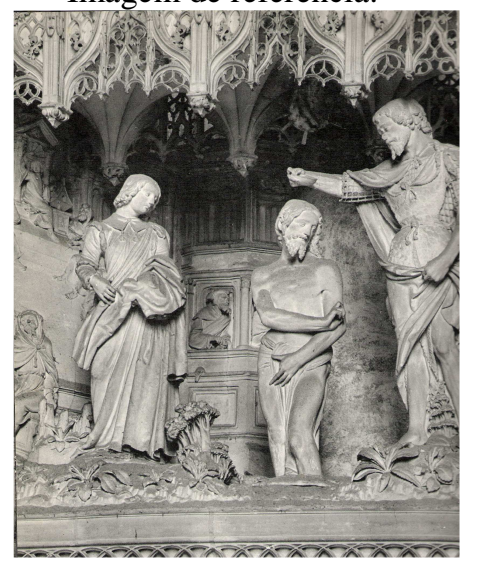

DELAPORTE $(1957,45)$

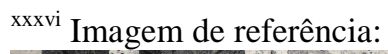

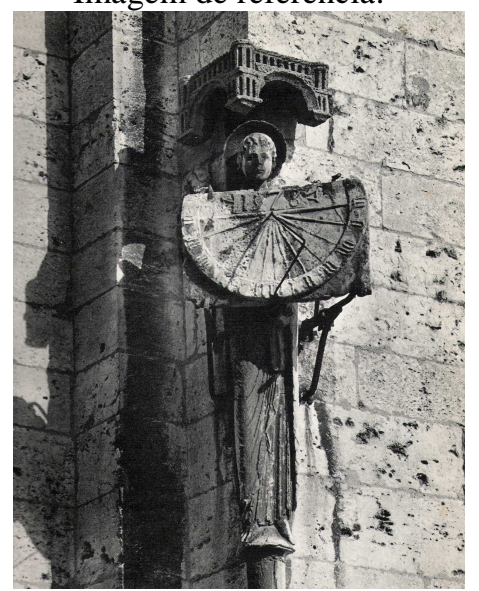

DELAPORTE $(1957,10)$

xxxvii Imagem de referência: 

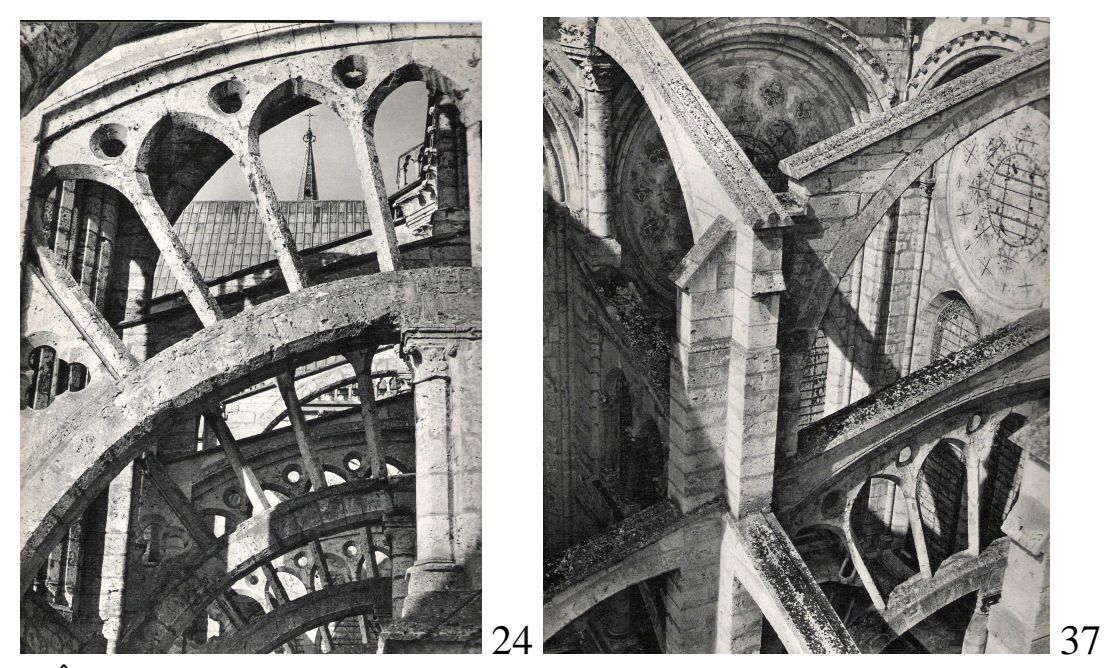

MÂLE (1948, 24 e 37)

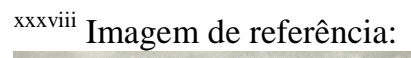

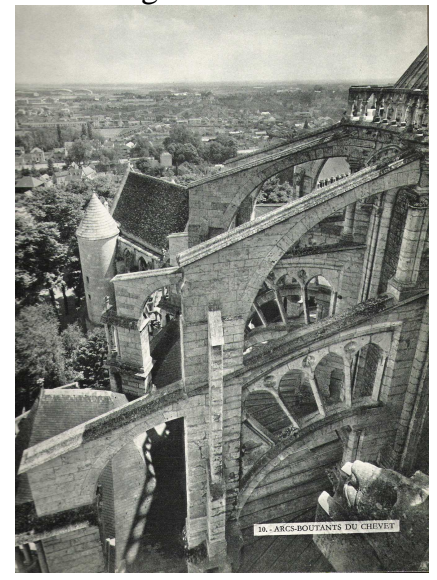

AUBERT $(1952,10)$

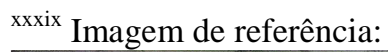

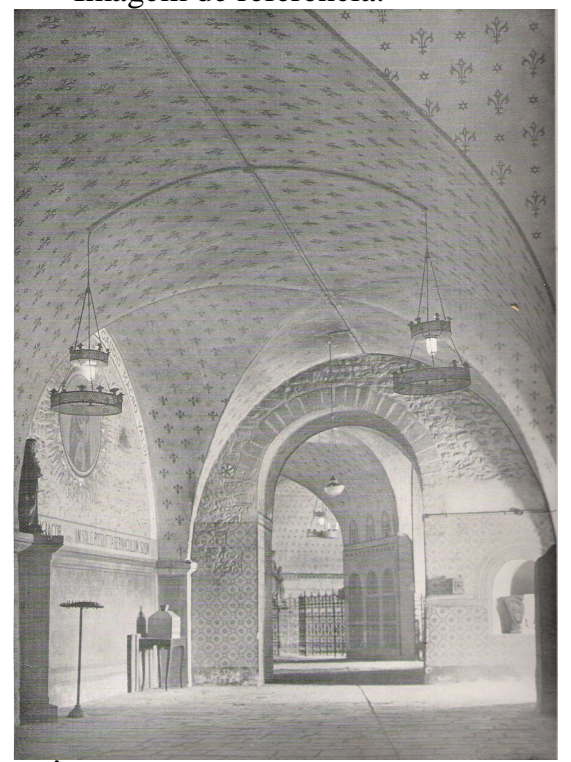

MÂLE $(1948,96)$

${ }^{\mathrm{xl}}$ Imagem de referência: 

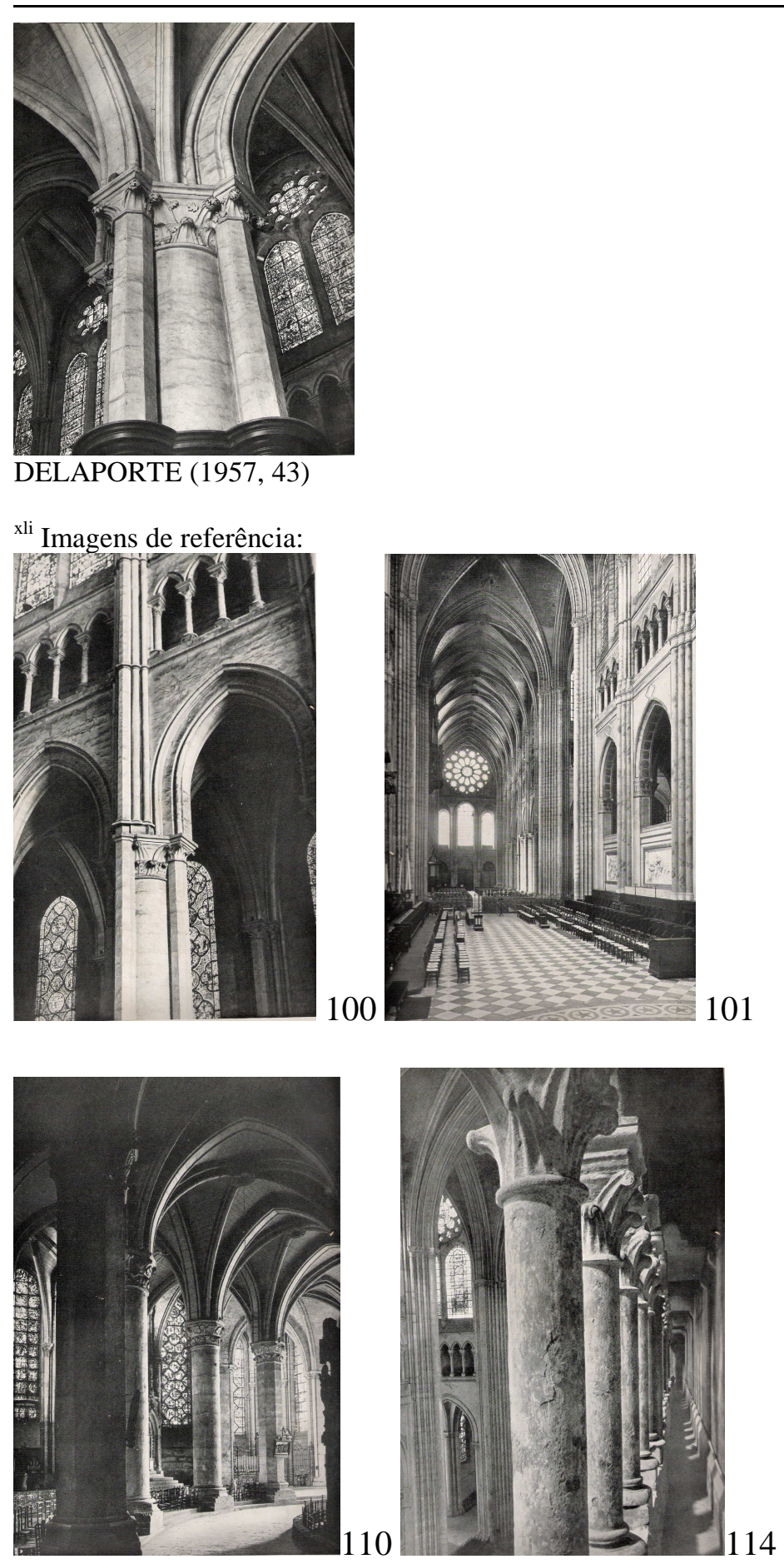

MÂLE $(1948,100,101,110,114)$

xlii Imagem de referência:

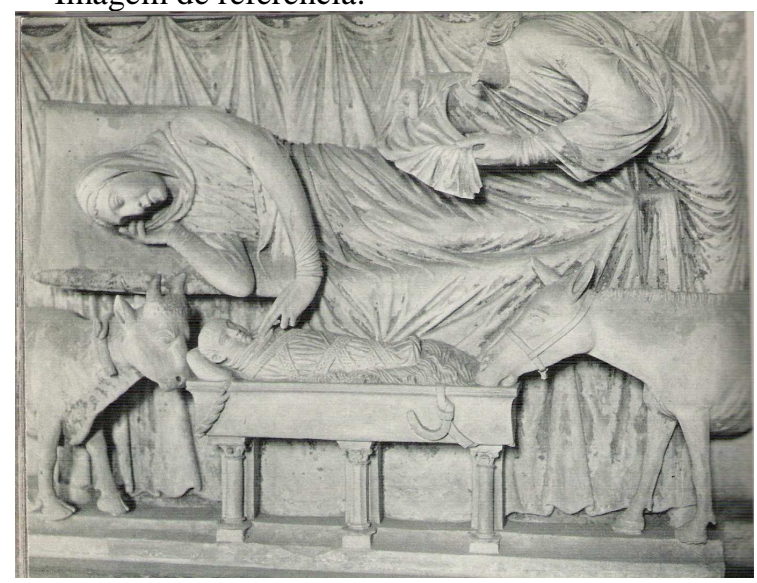


AUBERT (1952,. 88)

xliii Imagem de referência:

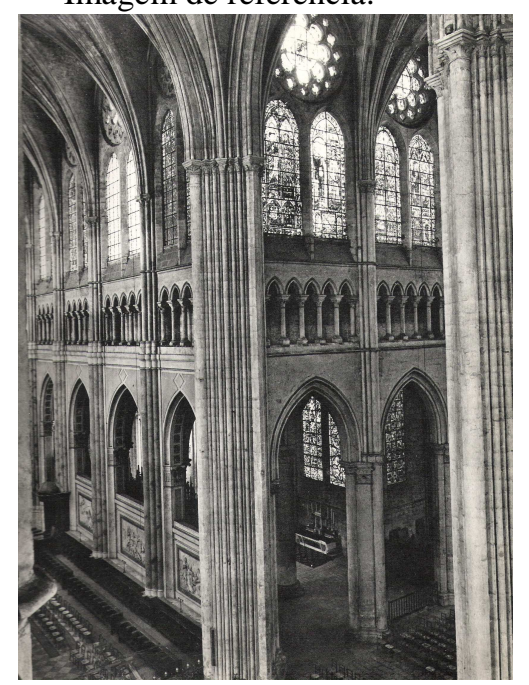

DELAPORTE (1957, 38-39)

${ }^{\text {xliv }}$ Imagem de referência:

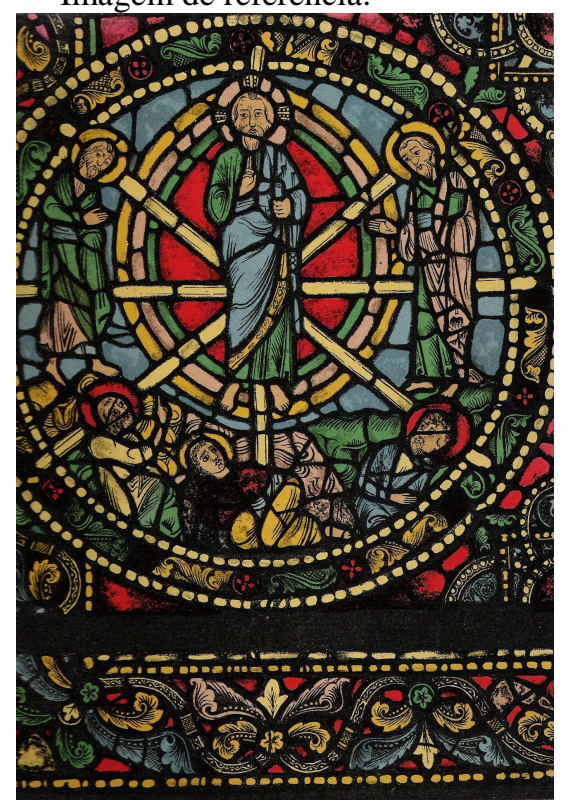

AUBERT (1952, III)

${ }^{\text {xlv }}$ Imagem de referência:

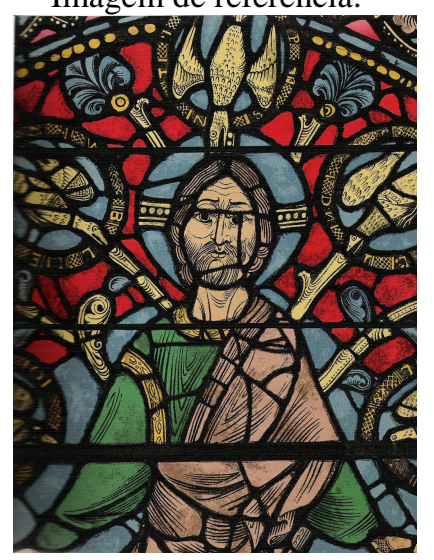

AUBERT (1952,. I)

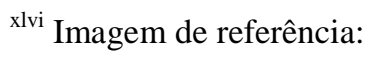

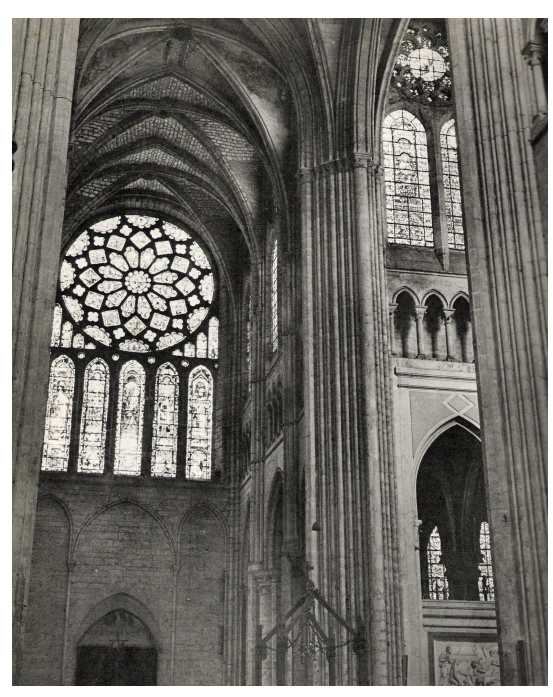




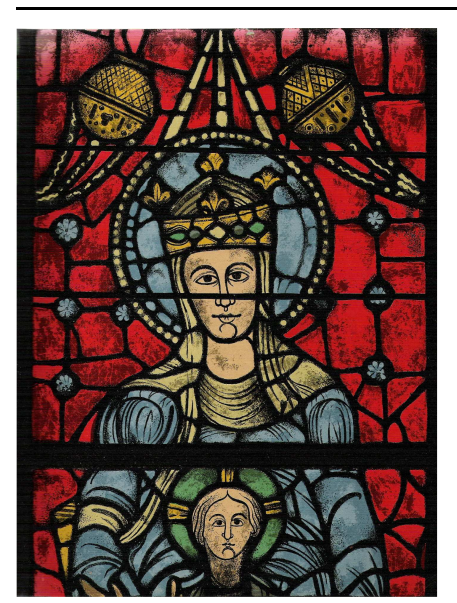

AUBERT (1952, IV)

xlvii Imagem de referência:

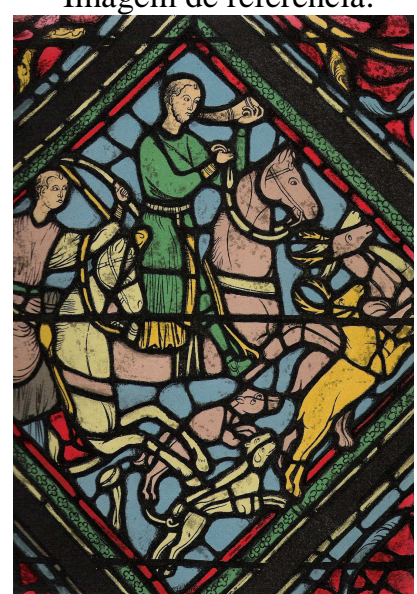

AUBERT (1952, VI)

xlviii Imagem de referência:

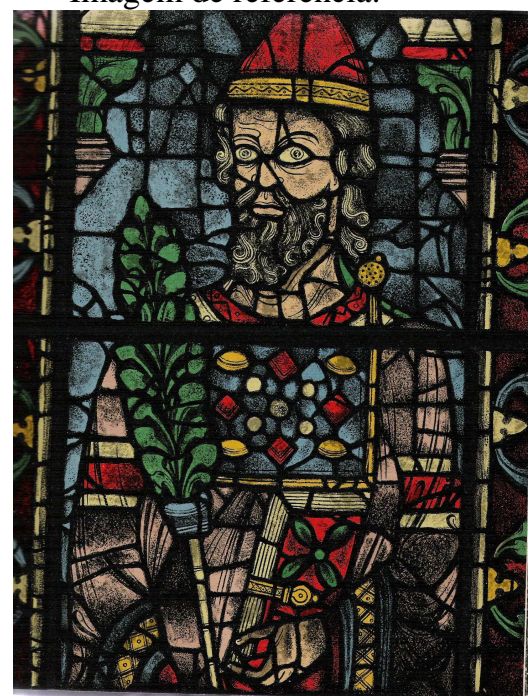

AUBERT (1952, VII)

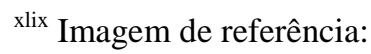




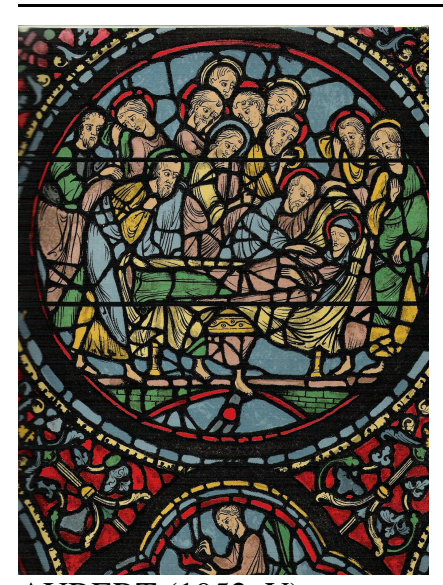

AUBERT $(1952, \mathrm{~V})$

${ }^{1}$ Imagem de referência:

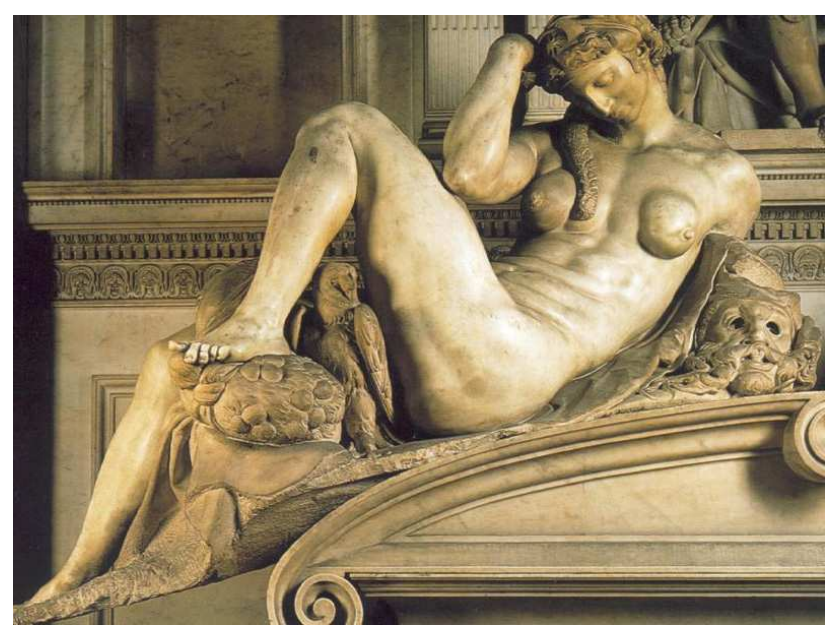

http://www.all-art.org/early renaissance/michelangelo6.html $22 / 11 / 2011$

${ }^{\text {li }}$ Imagem de referência:

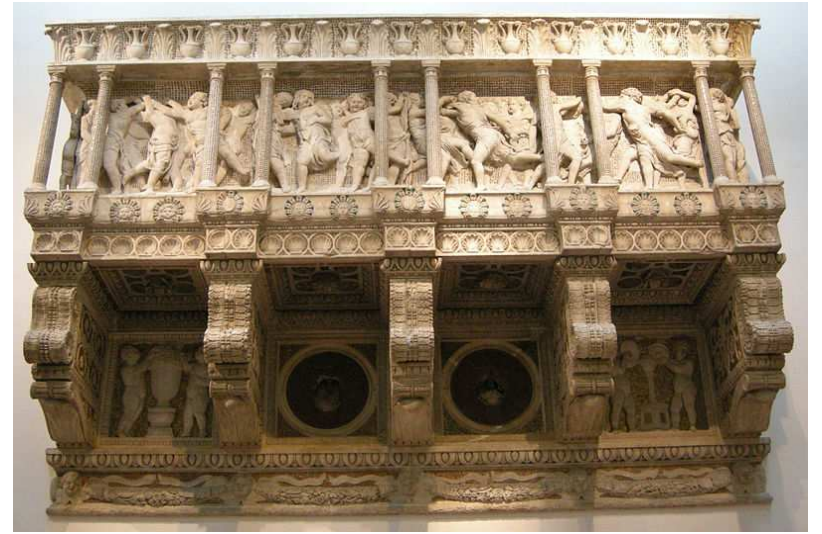

http://it.wikipedia.org/wiki/Cantoria_di_Donatello $22 / 11 / 2011$

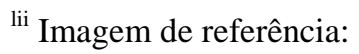




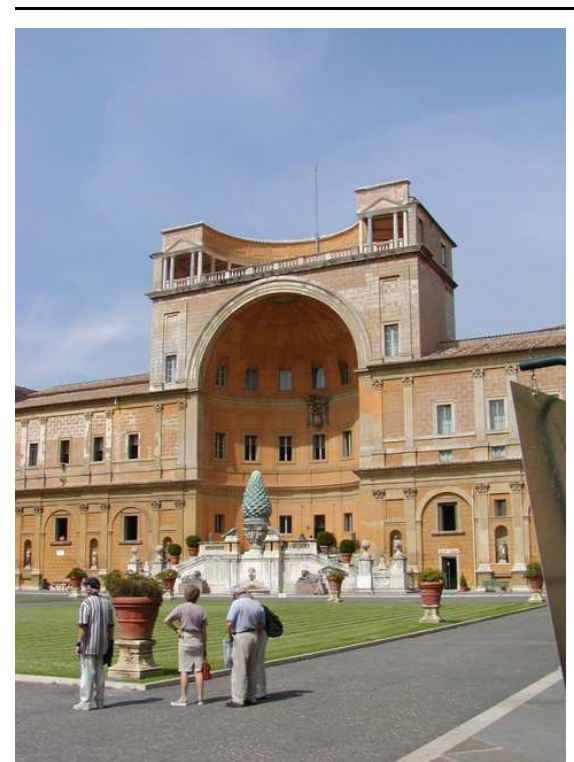

http://sights.seindal.dk/img/large/9060.jpg

22/11/2011

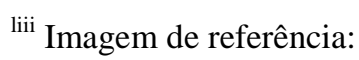

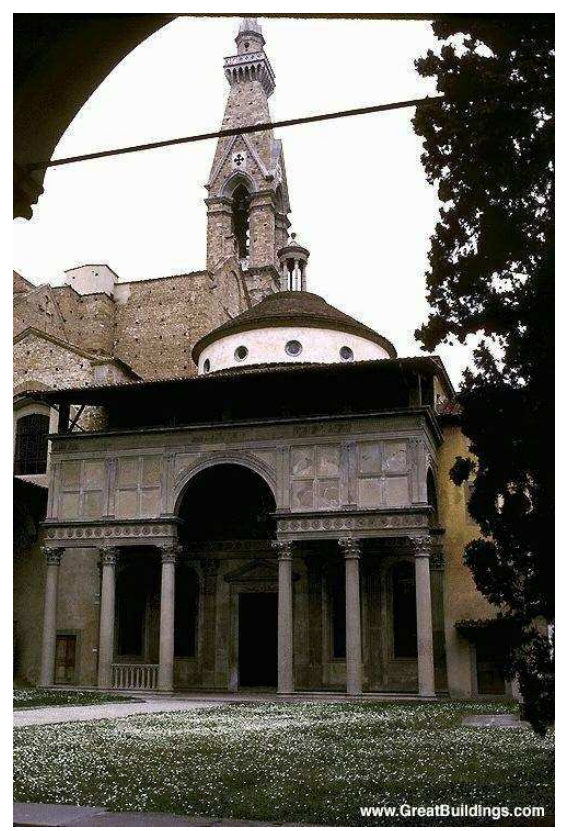

http://data.greatbuildings.com/gbc/images/cid_2397304.jpg 22/11/2011

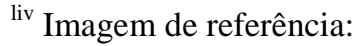




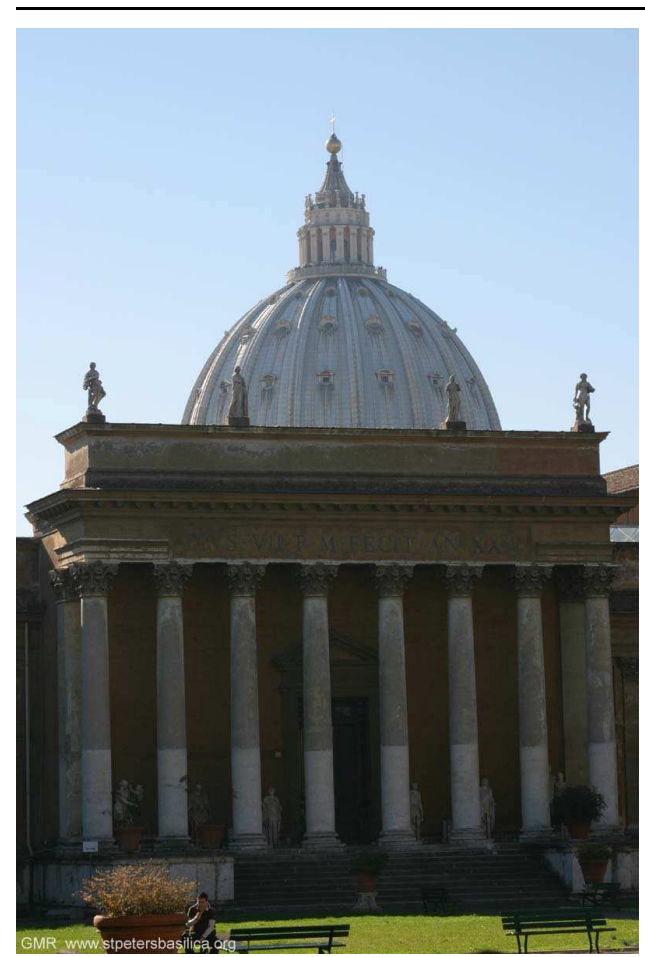

http://saintpetersbasilica.org/Exterior/Dome/frVaticanMuseums.jpg 22/11/2011

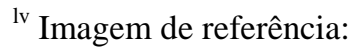

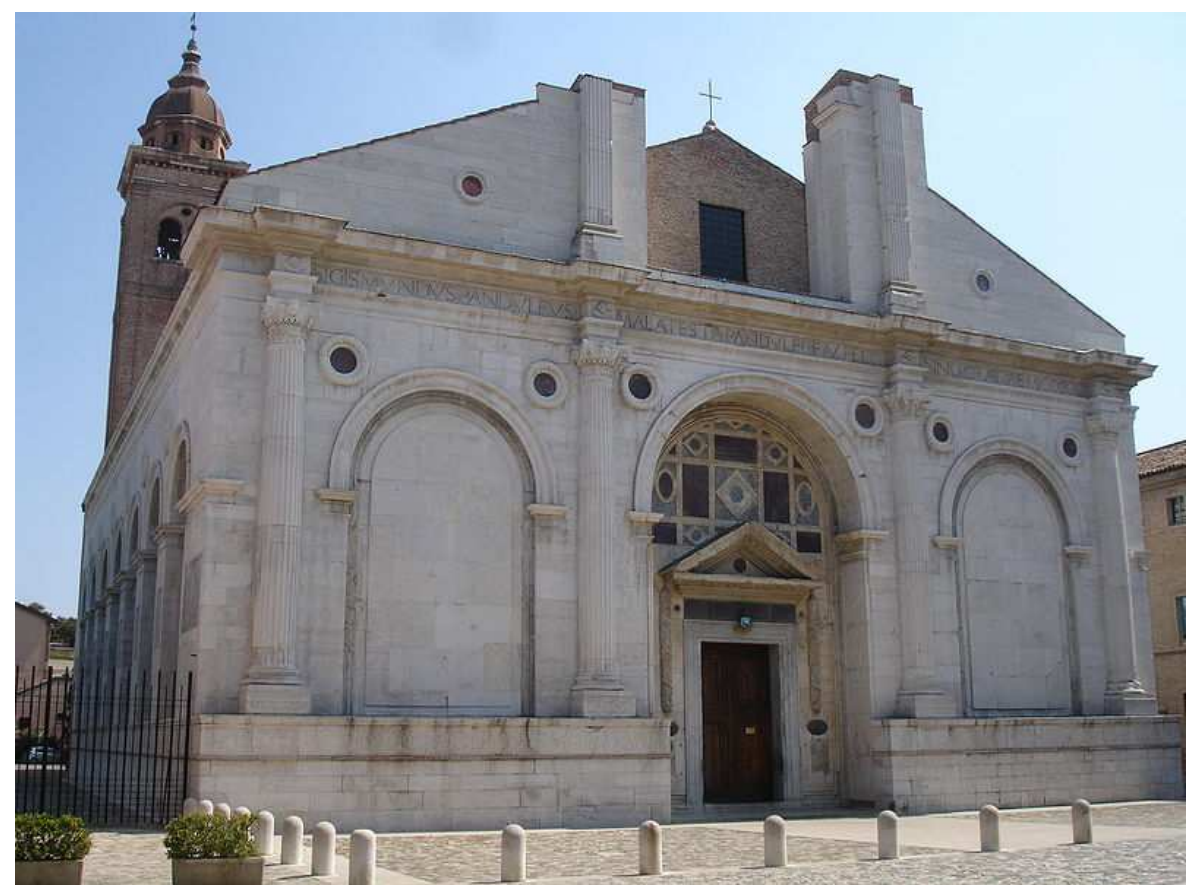

http://en.wikipedia.org/wiki/Tempio_Malatestiano

22/11/2011

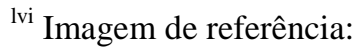




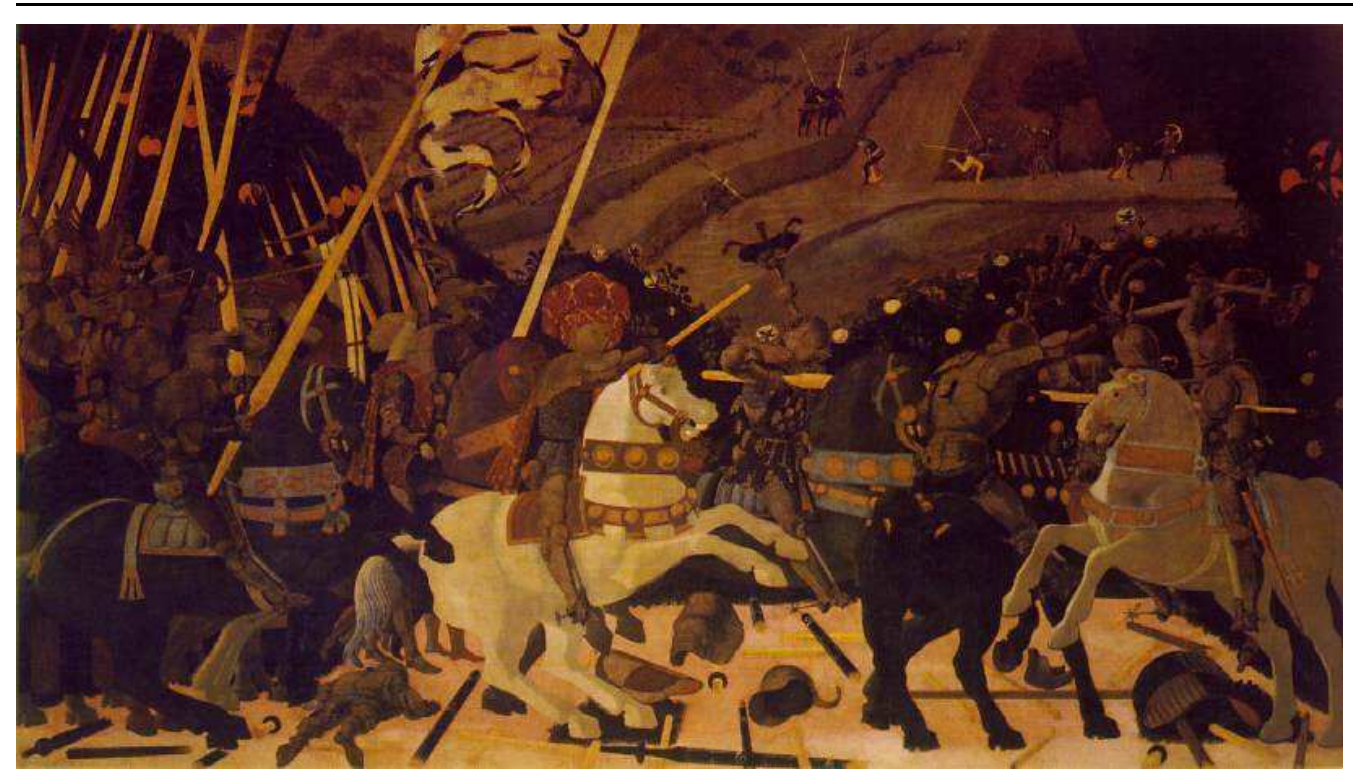

http://www.ibiblio.org/wm/paint/auth/uccello/i/rout-san-romano.jpg $22 / 11 / 2011$

lvii Imagem de referência:

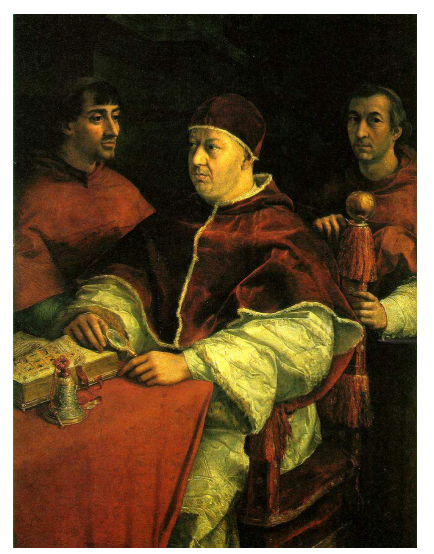

http://www.ibiblio.org/wm/paint/auth/raphael/popeleox/popeleox.jpg 22/11/2011

lviii Imagem de referência:

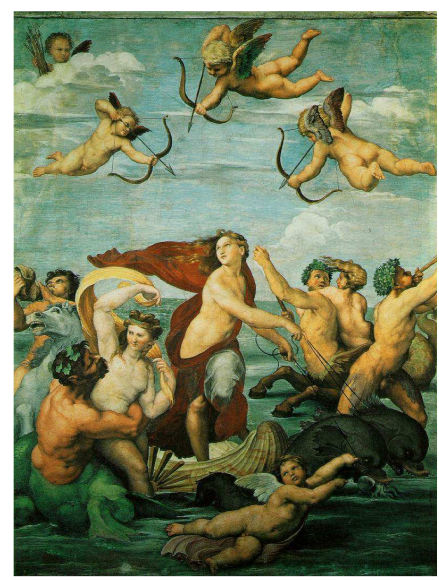

http://www.artchive.com/artchive/r/raphael/galatea.jpg 22/11/2011 


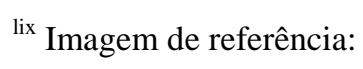

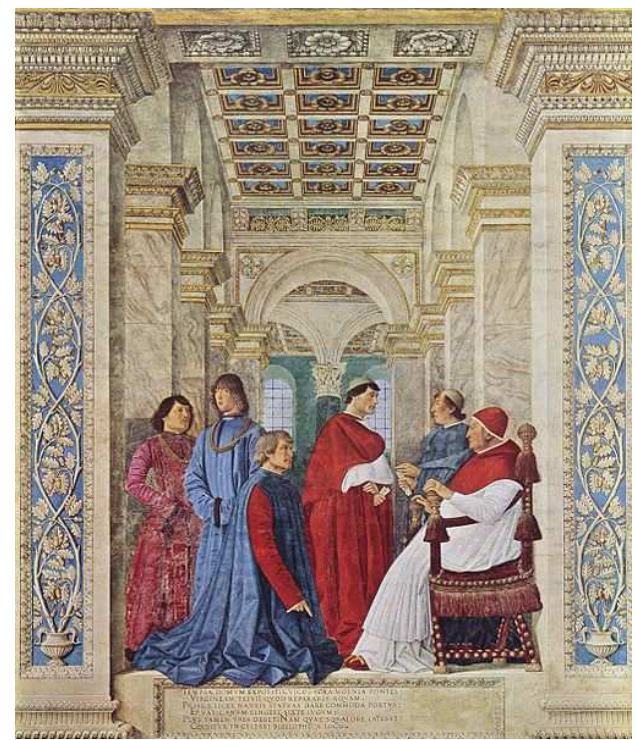

$\underline{\text { http://it.wikipedia.org/wiki/Sisto_IV_nomina_il_Platina_prefetto_della_biblioteca_Vaticana }}$ $22 / 11 / 2011$

${ }^{\mathrm{lx}}$ Imagem de referência:

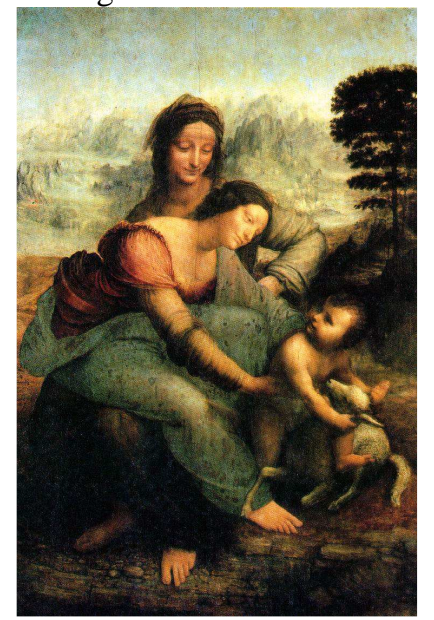

http://www.artchive.com/artchive/l/leonardo/leonardo_stanne_cartoon.jpg $22 / 11 / 2011$

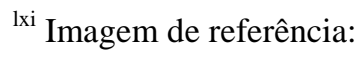

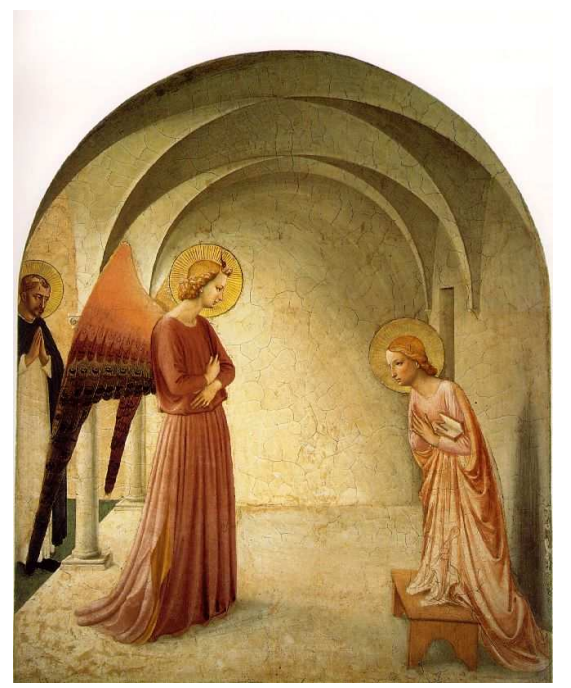

http://www.artchive.com/artchive/f/fra_angelico/angelico_convent3.jpg 
$22 / 11 / 2011$

Ixii Referência completa:

MOTGOLFIER, Bernard de.

GALLET, Michel. La Renaissance in Italie. I e II. Editions Rencontre Lausanne, 1965.

[Coleção] Images dês Grandes Civilizations. 